\title{
Self-Conscious Francophone Sub-Saharan African Cinema
}

\author{
Anna Vendla Keefe \\ Stillwater, Minnesota
}

B.A., University of Minnesota, Morris, 2005

M.A., Boston College, 2010

\begin{abstract}
A Dissertation presented to the Graduate Faculty of the University of Virginia in Candidacy for the Degree of Doctor of Philosophy

Department of French
\end{abstract}

University of Virginia

January 2016 


\section{Table of Contents}

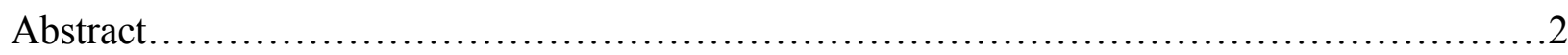

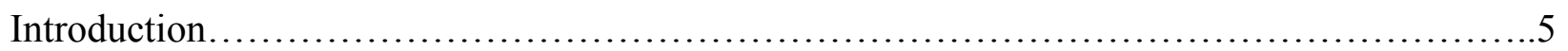

Chapter One. 'We all belong to Chaplin': Charlie Chaplin and Silent Film in Francophone Sub-

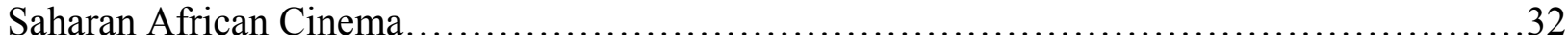

Chapter Two. Screening Alternatives: A New Political Film Language - Les Saignantes and Juju

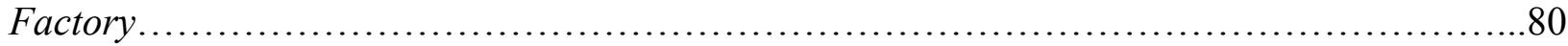

Chapter Three. Questioning African Cinema: Performativity in Bye Bye Africa and Lieux

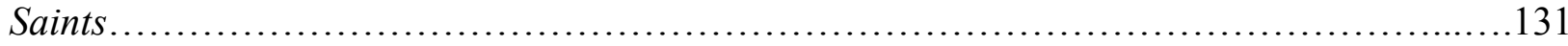

Conclusion.................................................................. 190

Appendix 1. La Guilde, Pour un nouveau cinéma africain..................................195

Appendix 2. Interview with Jean-Pierre Bekolo..................................... 197

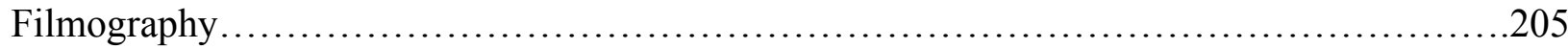

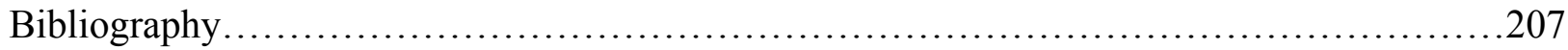




\begin{abstract}
Self-Conscious Francophone Sub-Saharan African Cinema brings together films by francophone sub-Saharan African directors that are, in varying degrees, about cinema. I use the term self-conscious cinema to define a mode of representation, strategy, or device through which the films in this project's corpus display awareness of themselves as films, and awareness of their place within a broad landscape of filmmaking. The films in this study display consciousness of cinema as an art form, as a way to demonstrate their affinities with directors and film styles worldwide, and as a powerful tool with which to approach pertinent, even urgent, socio-political issues, as well as issues in African cinema. I develop the notion of self-conscious cinema through close readings of films by directors as diverse in style as Ousmane Sembène, Djibril Diop Mambéty, José Zéka Laplaine, Jean-Pierre Bekolo, Balufu Bakupa-Kanyinda, Mahamat-Saleh Haroun, and Jean-Marie Teno. In analyzing such films, I mobilize aspects of film history, film theory, and knowledge of certain material factors such as production, distribution, and exhibition, in order to understand the larger implications of the kind of self-conscious filmmaking this corpus typifies. By focusing on new cinematic affinities in African films, and contemporary directors' collective efforts at advancing African cinema aesthetically and conceptually, this project works to gain a more thorough understanding of the place from which francophone sub-Saharan African cinema emerged, and the directions it is now taking.

Chapter One examines the prevalence of references to Charlie Chaplin and the silent mode over the course of francophone sub-Saharan African filmmaking. Directors from different generations and nationalities allude to Chaplin's work and the silent mode through thematic, stylistic, or structural elements in their films, through which they stake a claim to a world cinema heritage. Chapter Two analyzes Jean-Pierre Bekolo's Les Saignantes (2005) and Balufu Bakupa-
\end{abstract}


Kanyinda's Juju Factory (2007), two fiction films that deploy a similar narrative and aesthetic strategy of enacting the process of making a film as a way to subvert or overcome certain types of authoritative discourse. This strategy, I argue, articulates a new political film language in African cinema. Chapter Three examines Mahamat-Saleh Haroun's semi-documentary Bye Bye Africa (1999), and Jean-Marie Teno's documentary Lieux Saints (2009), and their questioning of African filmmaking and spectatorship. Both films put into practice a mode of representation that seeks to resolve the very issues that they name, and in this sense their films are reminiscent of performative documentary according to Stella Bruzzi’s approach to the mode. Redefining the future of African cinema inevitably entails reflecting on the filmmaker's role and, as I argue, each filmmaker displays an acute awareness of this, and suggests a new role for the African filmmaker. 
With deepest gratitude to Alison.

For Ted, whose love, patience, and humor made this project possible. 


\section{Introduction}

"When I was a child, going to the movies was so important. It was a place almost like a church where people were seated looking at the priest make his cinema." -Jean-Marie Teno ${ }^{1}$

The Cameroonian filmmaker Jean-Marie Teno equates the significance of going to the movies during his youth with that of a sacred event. Also a movie lover from a young age, Ousmane Sembène went to great lengths to see the latest pictures playing at the Rialto, one of many movie theaters in Dakar in the late 1930s and early 40s. He dived into the sea to collect coins tossed by tourists aboard ships entering the bay, sold empty cement sacks and whatever other objects he could find, and sneaked in without paying when he could not afford a ticket. Even outside of show times, young Sembène often lingered in front of the theater eyeing the movie posters. ${ }^{2}$ In addition to the 'father of African cinema,' and Teno, Jean-Pierre Bekolo, Balufu Bakupa-Kanyinda, Mahamat-Saleh Haroun as well as other filmmakers from francophone West and sub-Saharan Africa caught le virus du cinéma at a young age. Cinephiles, they allude to their love of movies in their works, such as through the depiction of movie consumption. Scenes feature characters watching movies on the big screen, at video rooms, or gathering around a television in a central courtyard. In À nous la rue! (1987), a short film directed by Moustapha Dao, children rush to the cinema after school for a silent comedy. Moussa Sène Absa's Ça twiste à Popenguine (1994) depicts youth's enjoyment of shadow play, a pre-

\footnotetext{
${ }^{1}$ Cited in Michael T. Martin and Marissa Moorman, "The Civilising Mission of Globalisation: Technology, African Cinematic Practice and Overcoming Neocolonialism: A Conversation with Film-maker Jean-Marie Teno," Third Text 29, no. 1-2 (2015), 67.

2 Samba Gadjigo, Ousmane Sembène: The Making of a Militant Artist, trans. Moustapha Diop (Bloomington: Indiana University Press, 2007): 43-44, 47. Gadjigo draws a connection between Sembène's practice of collecting and re-selling random goods and his metaphor for the state of African cinema, mégotage. The term, which is well known among filmmakers and scholars alike, characterizes the débrouillard style of African film production in its early days. It comprises mégot, the French word for cigarette butt, montage (editing), and bricolage, referring to the do-it-yourself nature of manual tasks. For Sembène, putting together a film with limited means, like piecing together a cigarette using butts, emphasizes the difficulties African directors have faced with respect to the material aspects of film production. Gadjigo illustrates the idea of mégotage with the example of Sembène's first short feature, Borom Sarret (1963), which was made with an old Russian camera and random scraps of film (ibid., 47).
} 
cinematic device, and moving images on the village's first television set. The tsotsis, or gang members, in Jean-Pierre Bekolo's Aristotle's Plot (1996) pass the time watching American B movies and mocking African films. Memorable scenes in both Dani Kouyaté's Ouaga Saga (2004) and Abderrahmane Sissako's Bamako (2006) feature characters watching westerns. In these and other titles, depictions of film consumption and reception are one of several ways African films display an awareness of their status as films and their place within a vast cinematic landscape.

This dissertation brings together films by francophone African filmmakers that are, in varying degrees, about cinema. The films emphasize that they are about film, and about filmmaking. They deploy narrative and aesthetic strategies to foreground their creation and intertextual influences. They allude to the past and present states of African filmmaking as well as to other cinematic traditions, ranging from early twentieth-century practices in Hollywood to the French New Wave. They display awareness of the structures of production, exhibition, and distribution that surround them. The films draw the viewer's attention to the inner workings of the cinematic medium by revealing elements that are traditionally concealed in the invisible style of classical realist cinema, such as the filmmaking process, the filmmaker, the screen, the projector, and spectators. Prompted by these various types of cinematic self-consciousness, this project asks why there are many recent francophone African films that are clearly about film. Is the self-conscious style or strategy in one title similar to or divergent from that in another film? How does a film's context of production inflect the director's approach to film language? In examining these and other questions, this study works to gain a fuller understanding of the place from which francophone sub-Saharan African cinema emerged, and the directions it is now taking. 
This project examines feature-length films by contemporary directors as diverse in style as Jean-Pierre Bekolo, Balufu Bakupa-Kanyinda, Mahamat-Saleh Haroun, and Jean-Marie Teno. Born roughly a decade apart, their backgrounds vary considerably. Teno was born in Cameroon in 1954 and studied communication and filmmaking at the Université de Valenciennes. BakupaKanyinda was born in the Democratic Republic of the Congo in 1957, and first attended university in Belgium, followed by studies in filmmaking at ARSCIPRO in Paris, the Fine Arts School in Cambridge, and workshops in North America. ${ }^{3}$ Haroun, who was born in 1961 in Chad, studied filmmaking at the Conservatoire Libre du Cinéma Français (CLCF) in Paris, as well as journalism in Bordeaux. Bekolo, born in Cameroon in 1966, received his training in film editing at the Institut National de l'Audiovisuel (INA) in Paris, where he studied under Christian Metz. Despite the range in nationalities, educational backgrounds, and individual film styles, their films all foreground film and filmmaking: Bye Bye Africa (Haroun, 1999), Les Saignantes (Bekolo, 2005), Juju Factory (Bakupa-Kanyinda, 2007), and Lieux Saints (Teno, 2009).

Self-conscious tendencies are not, however, limited to more contemporary works. The tendency that emerges in full force in the films by Haroun, Bekolo, Bakupa-Kanyinda, and Teno, has antecedents in earlier films. Works by Ousmane Sembène (Xala, 1975) and Djibril Diop Mambéty (Badou Boy, 1970; Le Franc, 1994), and films by Bekolo (Aristotle's Plot), BakupaKanyinda (Le Damier) and José Zéka Laplaine (Le Clandestin), all released in 1996, reveal a trajectory building over time. In addition to having an extensive chronology, this project explores the self-conscious tendency in films that are short, medium, and feature length; fiction, documentary, and films that straddle the two modes; and films that cover a breadth of genres, from comedy to science fiction. By analyzing the tendency in an array of modes, genres, and

\footnotetext{
${ }^{3}$ ARSCIPRO, or the Association pour la Réalisation de Stages de Cinéma Professionnel, is a non-profit organization run by Jacques Gurfinkiel.
} 
styles, this project identifies several types of self-consciousness that correspond to directors' various projects. The principal self-conscious tendencies that this project identifies and addresses are intertextual, political, and performative; tendencies that are ludic, nostalgic, reflective, and/or subversive in nature. Self-conscious tendencies correspond to a filmmaker's awareness of what African filmmaking entails in a specific socio-historical context.

I have chosen the term self-conscious cinema to define a mode of representation, strategy, or device through which the films in this project's corpus display awareness of themselves as films, and awareness of their place within a broad landscape of filmmaking. The term is highly similar in definition and usage to self-reflexivity, a term that I employ in this project to refer to meta-discursive moments in film. ${ }^{4}$ From the Latin reflexio, meaning to bend back on or reflect, reflexivity is a broad notion that, as Robert Stam points out, "has generated a swirling galaxy of satellite terms pointing to specific dimensions of reflexivity." ${ }^{, 5}$ Critical terms that designate such practices in artistic and cultural production include metafiction, narcissistic narrative, antiillusionism, self-referentiality, self-reflectivity, and mise-en-abyme. ${ }^{6}$ In Reflexivity in Film and Literature: From Don Quixote to Jean-Luc Godard, Stam defines reflexivity as "the process by which texts, both literary and filmic, foreground their own production, their authorship, their intertextual influences, their reception, or their enunciation." Stam's book draws from Christian Metz' important work on the subject, which emphasizes that the artistic and cultural practice always refers back to the work itself. Metz defines enunciation as "the semiologic act by which

\footnotetext{
${ }^{4}$ By including the prefix "self" in self-reflexive, I wish to emphasize that the artistic practice refers back to the text itself.

5 Harper's Latin Dictionary, s.v. "reflexio." Robert Stam, Reflexivity in Film and Literature: From Don Quixote to Jean-Luc Godard (New York: Columbia University Press, 1992), xiv.

${ }^{6}$ As Stam observes, the terms associated with reflexive practices "belong to morphological families with prefixes or roots deriving from the 'auto' family, the 'meta' family, the 'reflect' family, the 'self' family, and the 'textuality' family (ibid., xiv).
} 
some parts of a text talk to us about this text as an act." ${ }^{, 7}$ For example, the presence of a window (or other type of frame) within the frame of the film reproduces the position of the spectator and serves as a reminder "both of the nature of what is going on-a film projection, a vision in a rectangle-and the part [the spectator is] playing in it." ${ }^{8}$ Additional "enunciative positions" for Metz include "film in the film, off-address, in-address, subjective image, shot/reverse shot, flashback, and so on...cinema does not have a closed list of enunciative signs, but it uses any sign (as in [the] example of the window) in an enunciative manner" (emphases in original). ${ }^{9}$ All instances of enunciation point to the film itself, a fact inherent to the definition of enunciation. "Cinematic enunciation is always enunciation on the film. Reflexive [...] it does not give us any information about the outside of the text, but about a text that carries in itself its source and its destination."10

The conventions of mainstream cinematic forms have been established by years of fiction filmmaking practice. These conventions, including continuity editing, have become so widely used that they have become virtually invisible to audiences, as David Bordwell and Kristin Thompson demonstrate. ${ }^{11}$ Films that follow these conventions sustain the illusion of spatial, temporal, and action continuity. Self-reflexive techniques break the illusion of continuity. Artists "choose, for a variety of reasons, to subvert and undermine their tale," Stam writes. "To the suave continuities of illusionism, [anti-illusionistic art] opposes the rude shocks of rupture and

\footnotetext{
${ }^{7}$ Stam, Reflexivity in Film and Literature, xiii. Metz bases his discussion of film language on Emile Benveniste's theory of enunciation. He posits that the theoretical search for the equivalent in cinema of the "deictics" of verbal language have been misguided since theorists should have simply been looking for the phenomenon of reflexivity. Metz, "The Impersonal Enunciation, or the Site of Film (In the Margin of Recent Works on Enunciation in Cinema)," trans. Béatrice Durand-Sendrail and Kristen Brookes, New Literary History 22, no. 3 (Summer 1991), 754. ${ }^{8}$ Ibid.

${ }^{11}$ David Bordwell and Kristin Thompson, Film Art: An Introduction (Boston: McGraw-Hill, 2004).
} 
discontinuity." ${ }^{12}$ Narrative realism and self-reflexivity are not necessarily antithetical qualities, as Stam aptly points out: films may "combine a measure of realism with reflexive technique. They illuminate the everyday realities of the social conjunctures from which they emerge, while also reminding their $[\ldots]$ spectators of the artificiality of their mimesis."13 Breaking the conventions of established cinematic codes by making the cinematography and editing visible to the audience leads to more active viewing, as theorists such as Laura Mulvey have argued. ${ }^{14}$ From a willing suspension of disbelief, a phrase famously coined by Samuel Taylor Coleridge, self-reflexivity occasions disbelief, doubt, and deception. This relates to Russian Formalist Viktor Shlovky's concept of ostranenie, a distancing device, and to Bertolt Brecht's view that the structure of a theatre piece could heighten the audience's critical engagement and identification with the work's content. His grounds for breaking down the model of realism in theatre were to reveal and denounce the laws governing an oppressive society or a reigning ideology. Brecht's interest resides not only in showing that art lies, but in revealing that "society lies, and that human beings can do something about it."15

While some critics contend that self-reflexive devices in film, like breaking the fourth wall, compel the audience to assume an active interpretive response, which may lead to enhanced critical and intellectual engagement with the message, Dana Polan argues that conscious and deliberate self-reflexivity "may be nothing other than an expansion and making manifest of inherent qualities of art." ${ }^{16}$ He writes: "to a large extent, what we refer to as self-reflexivity represents one more strategy in the interplay of a technique intrinsic to and actually defining the

\footnotetext{
12 Stam, Reflexivity in Film and Literature, 7.

13 Ibid., 15.

14 Laura Mulvey, "Visual Pleasure and Narrative Cinema," Screen 16, no. 3 (Autumn 1975): 6-18.

15 Stam, Reflexivity in Film and Literature, 212.

16 Dana B. Polan, "Brecht and the Politics of Self-Reflexive Cinema," Jump Cut: A Review of Contemporary Media 1 (1974, 2004), http://www.ejumpcut.org/archive/onlinessays/JC17folder/BrechtPolan.html.
} 
process of art" (emphasis in original). ${ }^{17}$ Self-reflexive art, he continues, "appeals in part because it heightens [the] intrinsic interplay" between credulity and skepticism. ${ }^{18}$ If all art signals awareness of its own artifice to some degree, as Polan posits, then conscious artistic intervention compels us to take a deeper look at the type of self-reflexivity a work displays. Is it always political? To what extent does it revere or critique trends that have preceded it? To what extent does it explicitly correspond to the limits of its own context of production? How does it engage with broader trends and movements that transcend both space and time? Guiding this dissertation, these questions reflect not only this project's varied corpus but also the different types of selfconscious cinema at play.

Self-reflexive and self-conscious are practically interchangeable notions; in fact, selfconscious cinema is often self-reflexive, according to Stam's definition of reflexivity and Metz' definition of enunciation. The term self-conscious, however, more fully encompasses the dimensions of cinematic awareness displayed in the films in this project. Indeed, beyond characterizing the self-reflexive narrative and/or aesthetic devices that many of the films deploy, the term self-conscious cinema also encompasses the degree to which films evoke certain external factors. This varies from allusions to other directors, cinematic styles or movements, to implicit or explicit references to their material factors of production, distribution, exhibition, and/or reception. My approach might be described as attending to both the immanent and emanant aspects of film. By immanent, I mean locating meaning within the world of the film, and by emanant, I refer to knowledge of the external, material factors of a film's production that may inflect and/or be essential to understanding the film's mode of representation. This methodology inherits from and avoids practicing what Julianne Burton calls an "immanent

\footnotetext{
${ }^{17}$ Polan, "Brecht and the Politics of Self-Reflexive Cinema."

18 Ibid. Polan is borrowing from literary critic Frank Kermode, who described the interplay between confirmation and contradiction in art as one between credulity and skepticism, or between recognition and deception.
} 
criticism," which only focuses on the signifying practices within the filmic text. ${ }^{19}$ In her work on New Latin American Cinema, Burton proposes a critical methodology that is "based on 'modes of filmic production and consumption' defined not as exclusively immanent to the film-text but as originating in and exerting an impact upon the world outside it" (emphasis in original). ${ }^{20}$

The subject of each chapter in this dissertation illustrates these dimensions by analyzing, respectively, films that demonstrate affinities with Charlie Chaplin and the silent film era, films that demonstrate a new political film language, and films that question African cinema. Selfconscious cinema, simply put, is engaged cinema. The films in this study display consciousness of cinema as an art form, as a way to demonstrate their affinities with directors and film styles worldwide, and as a powerful tool with which to approach pertinent, even urgent, socio-political issues, as well as issues in African cinema.

A widely used and understood term, self-conscious means aware. This project explores the various types of awareness originating in the films. Self-conscious also refers to the realization of being the object of observation or attention, a state that may be accompanied by feelings of discomfort or feeling ill at ease. While I do not wish to imply that these films feel uncomfortable, this sense is not entirely outside the scope of our discussion. When a character addresses the camera and, by extension, the viewer, it can certainly lead to feelings of unease. A filmmaker entering the frame of the film can prompt the potentially disturbing question as to who is in control. These examples speak to the experience of the viewer, but feelings of selfconsciousness, or being-looked-at-ness, also have resonance in filmmaking practices, and stem from broader Western/outside constructions of the African continent. There are countless

\footnotetext{
19 Julianne Burton, "Film Artisans and Film Industries in Latin America, 1956-1980: Theoretical and Critical Implications of Variations in Modes of Filmic Production and Consumption," in New Latin American Cinema, ed. Michael T. Martin, vol. 1 (Detroit: Wayne State University Press, 1997): 157-84.

${ }^{20}$ Ibid., 164.
} 
examples in the history of representations of the African continent by directors, primarily from

Western Europe and America, who tend to focus on aspects that could be considered as negative stereotypes, or who leave out Africans entirely. ${ }^{21}$ Fully aware of these depictions, African directors seek to disrupt the narratives that structure both African societies and the continent's global image; Melissa Thackway refers to this strategy as "shooting back.,"22 This project does not develop a discussion, along the lines of Thackway's, of how postcolonial African directors challenge hegemonic representations of the African continent that are produced by dominant and often problematic discourses. However, this dimension of self-consciousness is foundational to the notion of self-conscious cinema.

The self-conscious tendencies examined in this study arise in part from the filmmakers' awareness of the divisions among political, popular, and art cinema in African filmmaking practices; from the patterns of financial support of francophone African film production; and from the status of exhibition and distribution of francophone African films both on and off the continent. Even though films were made on the African continent since the early days of the existence of cinema, it was not until the 1950s and 60s that sub-Saharan Africans began making their own films. ${ }^{23}$ Ousmane Sembène's short film Borom Sarret (1962), which depicts the

\footnotetext{
${ }^{21}$ Some examples include Sanders of the River, The African Queen, The Navigator, and the Tarzan films. For a deeper look at depictions of Africa in Hollywood films, see Kenneth M. Cameron, Africa on Film: Beyond Black and White (New York: Continuum, 1994); and Hollywood's Africa After 1994, ed. MaryEllen Higgins (Athens, OH: Ohio University Press, 2012). On a related note, Manthia Diawara discusses more recent examples of what he calls "humanitarian 'Tarzanism,"” or the story of the White savior, in films such as Blood Diamond and The Last King of Scotland. Diawara, African Film: New Forms of Aesthetics and Politics (Munich: Prestel, 2010), 76-82. For more on French film depictions of Africa, see Pierre Leprohon, L'exotisme et le cinéma. Les chasseurs d'images à la conquête du monde (Paris: J. Susse, 1945); Pierre Boulanger, Le Cinéma colonial: de "l'Atlantide" à "Lawrence d'Arabie (Paris: Seghers, 1975); and Cinema, Colonialism, Postcolonialism: Perspectives from the French and Francophone Worlds, ed. Dina Sherzer (Austin, University of Texas Press, 1996).

${ }^{22}$ Thackway, Africa Shoots Back: Alternative Perspectives in Sub-Saharan Francophone African Film (Bloomington: Indiana University Press, 2003).

${ }^{23}$ Filmmaking was underway in Egypt and Tunisia as early as the 1920s. Mbye B. Cham, African Experiences of Cinema, eds. Imruh Bakari and Mbye B. Cham (London: British Film Institute, 1996), 1. For more on early film production in North Africa and Egypt, see Roy Armes and Lizbeth Malkmus, Arab and African Film Making (London: Zed Books, 1991), 28-32.
} 
experiences of a cart driver in newly postcolonial Dakar, is often considered to be the first film by a sub-Saharan African that was made on the African continent. Prior to Borom Sarret, however, Albert Mongita made La leçon du cinéma in 1951 in what is now the Democratic Republic of the Congo, and Mamadou Touré's Mouramani (Guinea), and Emmanuel Lubalu's Les pneus gonflés (DRC) both appeared in 1953. In 1955, Mamadou Sarr, Paulin Vieyra, and the Groupe africain du cinéma (Senegal) made Afrique sur Seine in Paris. Since Afrique sur Seine was not made in Africa, Sembène's film La Noire de... (1966), about a young woman from Senegal working for a French family in southern France, is often considered the first feature film by a sub-Saharan African filmmaker. ${ }^{24}$ Due in large part to the intense socio-political climate of the years following independence, political engagement became a predominant narrative device used by filmmakers to approach questions regarding cultural and national identity and social issues. As David Murphy and Patrick Williams note, "cultural production has been inescapably tied up with the simultaneous production or reproduction of the nation." 25 Politically engaged stances and the "categorical embracing of a sense of responsibility as artists," as Melissa Thackway writes, were largely stipulated by the dictates of the Fédération Panafricaine des Cinéastes or FEPACI, including the Resolution of the Third World Film-Makers' Meeting in Algiers (1973), the Algiers Charter on African Cinema (1975), and the Niamey Manifesto of African Film-Makers (1982). ${ }^{26}$

\footnotetext{
24 Olivier Barlet, Les cinémas d'Afrique des années 2000: Perspectives critiques (Paris: L'Harmattan, 2012), 102-3.

${ }^{25}$ Murphy and Williams, Postcolonial African Cinema: Ten Directors (Manchester: Manchester University Press, 2007), 15.

${ }^{26}$ Thackway, Africa Shoots Back, 9. Reproductions of these texts appear in Afriques 50: singularités d'un cinéma pluriel, ed. Catherine Ruelle (in French), and in African Experiences of Cinema, eds. Imruh Bakari and Mbye Cham (in English). Alexie Tcheuyap argues that the FEPACI largely determined the cultural and ideological discourses that characterized African cinema; as a result, African film criticism followed suit and engaged in methodologies that mirror those discourses. See Tcheuyap, Postnationalist African Cinemas (Manchester: Manchester University Press, 2011), 1-32.
} 
However pervasive socio-realist filmmaking that chronicled the problems of postindependence societies was, a comedic and more commercial style emerged in the 1970s in the films of Daniel Kamwa and Henri Duparc. It is important to note, along with Melissa Thackway and Alexie Tcheuyap, that humor was not absent from African films prior to the appearance of these and other explicit comedies. ${ }^{27}$ With the diversity of filmmaking practices, the 'proper' preoccupations of African film became the focus of enduring ideological debates. Férid Boughedir and Nwachukwu Frank Ukadike dismiss the superficiality of films that aim primarily at amusement, while Pierre Haffner and Mweze Ngangura perceive entertainment films as best suited to respond to audiences' needs and desires. ${ }^{28}$ In addition to the popular cinema that is often associated with Mweze Ngangura, and the politically engaged cinema that is exemplified by Ousmane Sembène, critics have identified the formally experimental, avant-garde style of Djibril Diop Mambéty as apolitical, and as more or less art for art's sake. These divisions of political, popular, and apolitical filmmaking are, admittedly, quite schematic, and scholars have increasingly demonstrated filmmakers' integrations of the different positions. ${ }^{29}$

\footnotetext{
27 Thackway, Africa Shoots Back, 10; Tcheuyap, Postnationalist African Cinemas, 47.

${ }^{28}$ Boughedir, African Cinema from A to Z (Brussels: OCIC, 1992); Ukadike, Black African Cinema (Berkeley: University of California Press, 1994); Haffner, Essai sur les fondements théoriques du cinéma africain (Dakar: Nouvelles Éditions Africaines, 1978); Ngangura, “African Cinema: Militancy or Entertainment?" in African Experiences of Cinema, eds. Imruh Bakari and Mbye Cham (London: BFI, 1996): 60-64.

${ }^{29}$ For example, David Murphy and Patrick Williams argue that while Mambéty's films "do not espouse any readily identifiable point of view [...] that does not mean that they eschew politics altogether," and they identify within much of Mambéty's work a critique of the effects of capitalist modernity upon Senegalese society, among other concerns. Murphy and Williams, Postcolonial African Cinema, 94-109. Similarly, Dayna Oscherwtiz' article on Mambéty's Hyènes examines how the film critiques forms of economic imperialism. Oscherwitz, "Of Cowboys and Elephants: Africa, Globalization, and the Nouveau Western in Djibril Diop Mambéty's Hyenas," Research in African Literatures 39, no. 1 (Spring 2008): 223-38. Alexie Tcheuyap examines the comedic characteristics of Sembène's Xala. Tcheuyap, Postnationalist African Cinemas, 42-65. Murphy and Williams, and Akin Adesokan observe in Bekolo's approach a mix of the popular and the experimental; Adesokan refers to this as 'aesthetic populism.' Murphy and Williams, Postcolonial African Cinema, 193-200; Adesokan, Postcolonial Artists and Global Aesthetics (Bloomington: Indiana University Press, 2011), 108-32. Rachel Gabara discusses how Abderrahmane Sissako's films transcend the conventional opposition of political cinema and art cinema. Gabara, "Abderrahmane Sissako: Second and Third Cinema in the First Person," in Global Art Cinema: New Theories and Histories, eds. Rosalind Galt and Karl Schoonover (Oxford: Oxford University Press, 2010): 320-33.
} 
The French government's investment in cinema from the region of francophone sub-

Saharan Africa has fostered the growth of an art cinema or cinéma d'auteur above any other type of cinema. ${ }^{30}$ Rather than working to help implement lasting national or regional cinematic infrastructures, French support prioritized its cultural ties with its former African colonies. This arose in part from France's desire to assert itself as a leader on the international filmmaking scene, which was partially driven by fear of being subsumed by dominant industries, especially Hollywood. In her account on French and European funding for francophone African cinema, Teresa Heofert de Turégano traces the formal discourse among ministries, intergovernmental organizations, and associations, in which cultural legitimation is a constant. ${ }^{31}$ Each body has "their own formal cultural discourse, each strikingly similar to the other, each permeated with the idea of recuperating African cultural identities via film," she writes. ${ }^{32}$ This accent on cultural identity, she argues, has created a "cultural, non-commercial stream" of cinema. ${ }^{33}$ The French government's concerns continue to be “to sponsor 'prestige' African productions which can get European festival screenings, ideally at Cannes, and a successful release in one or more Parisian art cinemas," Roy Armes writes. ${ }^{34}$

\footnotetext{
${ }^{30}$ Rachel Gabara chronicles the attempts to define art cinema, noting that it first referred to European films that appeared in the middle of the twentieth century; canonical examples include Italian Neorealism and the French New Wave. As the term gained wider usage it came to refer to alternatives to mainstream Hollywood. David Bordwell identified a set of characteristics shared by art films, "focusing on the psychological complexity of their characters, their episodic and open-ended narratives, and their pursuit of ambiguity. It was now a film director or auteur, moreover, and not star, studio, or genre, who would serve as 'the overriding intelligence organizing the film for our comprehension."' Subsequent critics including Geoffrey Nowell-Smith and Steve Neale emphasized art cinema's shared production and distribution contexts, and particularly "their exhibition in an ever-growing number of national and international film festivals." Gabara, "Abderrahmane Sissako," 321.

${ }^{31}$ Teresa Hoefert de Turégano, African Cinema and Europe: Close-Up on Burkina Faso (Florence: European Press Academic Publishing, 2004).

${ }^{32}$ Ibid., 75.

${ }^{33}$ Ibid., 86.

${ }^{34}$ Roy Armes, African Filmmaking North and South of the Sahara (Bloomington: Indiana University Press, 2006), 148.
} 
With little to no distribution on the continent, and a highly limited number (if any) of movie theaters in each country, art films by francophone sub-Saharan African directors, typically enter the international film festival circuit. ${ }^{35}$ On the other hand, popular video movies made in industries in Nigeria, Ghana, and an increasing number of countries across the continent, have been highly successful in reaching local audiences. Nollywood specifically refers to the Englishlanguage Nigerian film industry, but the term popularly refers to the entire video-movie phenomenon. ${ }^{36}$ This model is significant because, as Kenneth Harrow points out, it "is the answer to African culture's quest for a viable economic basis that rests upon an African audience and its taste." 37 There is no French-language equivalent because, as Hoefert de Turégano suggests, the specific type of funding France offers has precluded a French-language videomovie industry like Nollywood. However, according to Manthia Diawara, a popular cinema is emerging among francophone directors, which he describes in terms of narrative choices (and belonging to recognizable genres, such as the Western, the action film, or the melodrama), and

\footnotetext{
35 "Analysis of the UIS International Survey on Feature Film Statistics," UNESCO Institute for Statistics (April 2009). The analysis was based on a preliminary study by Ivan Bernier and Serge Bernier.

${ }^{36}$ The video boom, as it is commonly referred to, began to take shape in Nigeria and Ghana in the late 1980s. This refers to low-budget films shot in digital format in two to three weeks, most of which are distributed by nationallyowned companies and that circulate through informal pathways throughout the continent. Based on these models, "budding industries in Kenya, Uganda, Tanzania, and Cameroon have emerged," Carmela Garritano writes in her monograph on Ghanaian video movies, African Video Movies and Global Desires: A Ghanaian History (Athens, OH: Ohio University Press, 2013). Video-movie industries have increasingly become sites of scholarly interest. Many studies have been devoted to the Nigerian video industry, especially its English-language productions, or Nollywood. There is also considerable video production in Yoruba and Hausa languages (the latter industry is called Kannywood), and smaller numbers are produced in Nupe and Bini. For more on the video movie phenomenon, see Jonathan Haynes, Nigerian Video Films: Revised and Expanded (Athens, OH: Ohio University Press, 2000); Onookome Okome, "Nollywood: Spectatorship, Audience, and the Sites of Consumption," Postcolonial Text 3, no. 2 (2007): 1-21; Mahir Şaul and Ralph A. Austen, Viewing African Cinema in the Twenty-First Century: Art Films and the Nollywood Video Revolution (Athens, OH: Ohio University Press, 2010). In addition to these and other works, several scholarly journals have devoted special issues to Nollywood and the rise in video films in recent years, including the issues of Journal of African Cinemas from Spring 2014 and July 2012; Black Camera from Spring 2014; and Postcolonial Text from 2007.

${ }^{37}$ Kenneth Harrow, Trash: African Cinema From Below (Bloomington: Indiana University Press, 2013), 6.
} 
their integration of elements from African popular culture, from popular religious beliefs and superstitions to folklore. ${ }^{38}$

As this very brief overview attempts to illustrate, one key question facing filmmakers has been and continues to be whether African films should seek higher aesthetic and political goals, at the risk of forgoing African audiences, or whether they should focus on catering to a mass market on the continent. Many francophone sub-Saharan African filmmakers continue to produce art films, even though there is considerable diversity among their practices and film styles. According to Melissa Thackway, this situation creates “an inordinate 'burden' on each film that does get made to represent, as in to speak or to stand for the totality of the African experience-in other words, a requirement that filmmakers be the voice of the communities from which they come. ${ }^{39}$ In fact, certain contemporary filmmakers see their roles in terms of the necessity of representing their compatriots and the daily realities they face to audiences outside the African continent. For instance, Abderrahmane Sissako describes his role as that of "a porteparole, a bearer of the words of others [...] from the African continent to anyone from the dominant culture who will listen," writes Alison Levine. ${ }^{40}$ Sissako explains, “"Africa is a continent that is spoken of often, but she rarely speaks for herself. I can make films, while so many others cannot." ${ }^{41}$ The idea of being a voice or porte-parole relates to the notion of selfconscious cinema; aware of the limited funding and distribution possibilities, critically acclaimed filmmakers such as Sissako carry the "burden of representation," in the words of Thackway. ${ }^{42}$

\footnotetext{
38 The directors whose films typify this new 'popular' African cinema include Mansour Sora Wade, Moussa Sène Absa, Cheick Fantamady Camara, Boubacar Diallo, and Mama Keïta. Diawara, African Film, 138-61.

39 Thackway, "Exile and the 'Burden of Representation': Trends in Contemporary Sub-Saharan Francophone African Filmmaking," Black Camera 5, no. 2 (Spring 2014): 10.

40 Alison J. Murray Levine, "Words on Trial: Oral Performance in Abderrahmane Sissako's Bamako," Studies in French Cinema 12, no. 2 (2012): 163-64.

41 Ibid., 164.

42 Thackway, "Exile and the 'Burden of Representation."”
} 
The self-conscious questioning that arises from the situation facing filmmakers is manifest in films by Bekolo, Bakupa-Kanyinda, Haroun, and Teno examined in this project: Les Saignantes, Juju Factory, Bye Bye Africa, and Lieux Saints. While stylistically these films look nothing alike, they all address and engage with contemporary issues concerning African filmmaking and spectatorship. The films confront various matters from socio-political issues, to forms of artistic repression, to the vast decline in movie theaters. An overarching feature that threads through these works is each filmmaker's commitment to advance African cinema aesthetically. Because of this explicit commitment, reading these works together provides a broader reading of a generation of African filmmakers' collective attempts to think through new directions in African cinema.

These filmmakers' experimentation with form and genre is part of a larger movement among contemporary African directors, which Manthia Diawara chronicles in his influential work, African Film: New Forms of Aesthetics and Politics. Diawara classifies the proliferation of new aesthetic forms as a "new wave of African cinema." Departing from Sembène's ideological stance and oppositional discourse, and the exotic and stereotypical images of Africa in the socalled "calabash cinema" of the 1980s and early 1990s, artists of the new wave are interested in "an active assimilation of new forms and languages in order to renew themselves and their visions of Africa." ${ }^{43}$ The new in the African new wave refers to contemporary directors' creativity and innovation in form and style. He explains,

the new wave of African filmmakers are no longer interested in applying an oppositional language to what is known as dominant American and European cinemas, but are more

\footnotetext{
43 Manthia Diawara, African Film: New Forms of Aesthetics and Politics (Munich: Prestel, 2010), 95. As Roy Armes notes, Pierre Haffner posits three waves of African filmmaking (the 1960s, the 1970s, and the 1980s-1990s), to which Armes adds the existence of a new wave or generation. Roy Armes, African Filmmaking North and South of the Sahara (Bloomington: Indiana University Press, 2006), 143.
} 
concerned with taking their place in the arena of world cinemas. To achieve this aim, they do not hesitate to borrow from, and to share with other directors, narrative forms that would have been considered less authentic from a Sembènian perspective. They are interested, as Senghor put it, in an active assimilation of new forms and languages in order to renew themselves and their visions of Africa. No longer afraid of the old accusations of alienation, they have turned their attention to inter-textual practices, cinematic appropriations and influences that enable them to achieve new creativity and self-renewal. ${ }^{44}$

Diawara separates new wave filmmakers into three strands, based on criteria ranging from their geographic locations, their films' contexts of production, and their intended audiences and/or distributions. First, the "Arte wave" consists of works produced by Arte, the Franco-German television network, during the period when Pierre Chevalier was director, 1991 to 2003 . The second strand, which he characterizes as independent-spirited, pan-African and diasporic, includes filmmakers who belong to La Guilde Africaine des Réalisateurs et Producteurs (The African Guild of Directors and Producers). The filmmakers in this category reside or spend the majority of their time outside of their countries of origin, often shuttling between Africa and Europe. Finally, the narrative strand describes the narrative-driven style of films that straddle the experimental, intellectual, art et essai concerns of the prior two strands, and the style of popular video movies. Whereas films that fall into the first two categories are primarily screened at festivals and American universities, films of the narrative strand, Diawara argues, cater to African spectators.

The contemporary filmmakers in this dissertation, Jean-Pierre Bekolo, Balufu BakupaKanyinda, Mahamat-Saleh Haroun, Jean-Marie Teno, and José Zéka Laplaine, all belonged to La ${ }^{44}$ Diawara, African Film, 94-95. 
Guilde Africaine des Réalisateurs et Producteurs. In fact, Teno was president from 1999 to 2001, Bekolo served as secretary-general, and Haroun was the chief writer and editor of the Guild's bulletin. Other Guild members include Abderrahmane Sissako, Fanta Régina Nacro, Dani Kouyaté, Nadia El Fani, Issa Serge Coelo, Mama Keïta, Jihan El Tahri, and François Woukoache. From the Guild's creation in France in 1998, its members were actively engaged in debate, conversation, and exchange in the pursuit of transforming African filmmaking and increasing its visibility. In addition to these aims, Olivier Barlet writes that the group wished to achieve solidarity especially with respect to funding institutions: "Son objectif premier était de ne plus aborder les bailleurs en ordre dispersé." 45 The Guild initially had a website, then a blog, and organized activities during large festivals such as Cannes and FESPACO. ${ }^{46}$

While internal disagreements and disputes ultimately led to the group's dissolution in 2007, the Guild was resolute in their commitment to transform African cinema. In their manifesto, titled Pour un nouveau cinéma africain, the Guild declares their intentions to carve out a space for African filmmakers in the global arena of cinemas. ${ }^{47}$ In this text, collectively authored by La Guilde, they highlight their commitment to contemporary issues on the continent: “En tant que cinéastes, nous ne pouvons pas fermer l'œil devant les problèmes actuels et urgents de l'Afrique." However, they emphasize that they are, first and foremost, filmmakers tout court. 'Nous n'oublions pas que nous sommes des cinéastes africains, mais nous sommes d'abord

\footnotetext{
45 Olivier Barlet, Les cinémas d'Afrique des années 2000: Perspectives critiques (Paris: L'Harmattan, 2012), 35. An open letter to the President and Director of CULTURESFRANCE published on the Guild's blog clearly conveys a desire for solidarity. Le Président (La Guilde Africaine des Réalisateurs et Producteurs), "Lettre à Messieurs Jacques Blot et Olivier Poivre d'Arvor Président et Directeur de CULTURESFRANCE," Guilde Africaine des Réalisateurs Producteurs (blog), October 23, 2007, http://laguildediaspora.blogspot.com

${ }^{46}$ For instance, during Fespaco 2007, the Guild organized a week devoted to screenings and workshops, La Semaine de Guilde.

${ }^{47}$ See Appendix 1 for a full reproduction of this text.
} 
cinéastes. ${ }^{, 48}$ As I demonstrate throughout this project, the films of Bekolo, Bakupa-Kanyinda, Haroun, Teno and Laplaine attest to this engagement through experimentation with cinematic form, and references to film theory and history.

In my approach to the films in this work, I analyze form as well as content. By form, I mean how a film is put together, from aspects of film space and sound, mise-en-scène (lighting, visible elements in the frame, décor), types of shots, camera angle, camera movement, and editing. Where productive, I bring aspects of film theory to bear on my discussion. My attention to the formal aspects of film situates this project in what we might term the "formalistic turn" in African film criticism. Until recently, African film scholarship was largely thematic and placed a particular emphasis on content. According to Kenneth Harrow, critics were under the impression that they "could not afford to indulge in sentimental, subjective explorations of individual sensibilities and personal relations, as in European New Wave cinema, while the larger questions of life or death import for the African community were at stake."49 In his groundbreaking work, Postcolonial African Cinema: From Political Engagement to Postmodernism, Harrow gives increased attention to form and aesthetics in African film, a central focus of Diawara's African Film: New Forms of Aesthetics and Politics. The appearance of both of these books has given rise to an increased attention to and interest in form in the study of film. This dissertation deepens and extends the attention to film form that Harrow, Diawara, and other scholars have begun, an approach that the formal experimentation and innovation in recent cinematic productions demand.

\footnotetext{
48 The above quote: "As filmmakers, we cannot ignore the contemporary, urgent issues that Africa is facing." This quote: "We do not forget that we are African filmmakers, but we are filmmakers first and foremost." (My translations)

49 Kenneth Harrow, Postcolonial African Cinema: From Political Engagement to Postmodernism (Bloomington: Indiana University Press, 2007), 22.
} 
In the opening line of Postcolonial African Cinema, Kenneth Harrow emphatically states that the time is ripe for new approaches in the study of African film by putting forth a "third cinema challenge" that is now frequently cited-and taken up-by scholars: "it is time for a revolution in African film criticism." ${ }^{50}$ For Harrow, a crucial step in undoing the patterns of dominant thinking that he feels have shaped and limited approaches to African cinema is deconstructing the binary opposition between surface versus depth. These patterns of thinking tend to emphasize realism, and are predicated upon the modernist approach, which "would have us interpret a film according to its underlying, hidden meaning, and that functions in accordance with values that are inextricably tied to varieties of realism." ${ }^{, 51}$ Realism, Harrow asserts, is "built upon an epistemology that posits the binary surface/depth and privileges depth...if there is one approach on textual analysis on which modernism has typically depended," he continues, "it is one in which the surface is understood to be of lesser importance-that is, superficial-while the underlying meaning or value is understood to be deep, profound, and meaningful." ${ }^{, 52}$ According to Harrow, realism "mimics the structures of credibility that are inevitably enmeshed in hierarchies of power." 53 In linking the notions of surface/depth and their relationship to modernity and colonialism, and to their production in African cinema, Harrow sees African cinema as a continuation of the "incomplete project of colonialism." ${ }^{, 54} \mathrm{He}$ argues that the way to overcome this crisis is to conceptualize African cinema in terms of its ability to give visibility to the surface.

\footnotetext{
${ }^{50}$ Harrow, Postcolonial African Cinema, xi. Harrow synthesizes the assumptions upon which, he believes, the 'old, tired formulas' and familiar paradigms have been based: that African cinema responds to history, that African cinema responds to Hollywood; that African cinema is representative of African society, people, culture; or that African cinema is "African" in any meaningful way (ibid.).

51 Ibid., 29.

52 Ibid.

53 Ibid., 15. Here, Harrow is drawing on Ann Stoler's notion of hierarchies of credibility.

54 Ibid., 37.
} 
In his exploration of the aesthetics of the surface, Harrow discusses African postmodern cinematic practices in Djibril Diop Mambéty’s Parlons Grand-mère (1989), Fanta Régina Nacro's short Un Certain matin (1991), and Jean-Pierre Bekolo's Aristotle's Plot (1996). While this dissertation does not develop an in-depth discussion of postmodernism, the notion of selfconscious cinema is a corollary of postmodernism in terms of its self-reflexive nature. Indeed, Les Saignantes, Juju Factory, and Bye Bye Africa display a postmodern sensibility by exposing the processes of film construction, and by revealing in various ways that the film is an act of cinema, an artificial construction. These films connect to those in Harrow's discussion by meditating upon cinema as an art form. In fact, they all cohere around a question that is raised in the final line of dialogue from Nacro's short film: "le cinéma, c'est quoi?" This question, which evokes André Bazin's Qu'est-ce que le cinéma?, indicates the staging of conceptual issues in cinema, a strategy that is also visible in the films examined in this dissertation. Harrow observes that this question in Nacro's film incites “a self-reflexive interrogation over our own relationship to what we have seen-a relationship [...] that is responsible for developing an awareness of a new level of consciousness so as not to remain trapped within the familiar world by an all-toopredictable script."

In Jean-Pierre Bekolo’s Aristotle's Plot (1996), the filmmaker explicitly attempts to deconstruct and break away from the notion of an "all-too-predictable script," to borrow Harrow's expression, referring to the conventions of African filmmaking as well as to the broader conventions of storytelling, stemming from Aristotle's Poetics. This film maps out the relationships between African filmmakers and African audiences in order to critically examine the status of African cinema. Because it experiments and engages with cinematic conventions

\footnotetext{
55 Harrow, Postcolonial African Cinema, 217.
} 
and African cinema in particular, it is a seminal film for this project. Many studies have been devoted to it, however, and I ultimately chose to focus on less studied works. ${ }^{56}$

Given the self-reflexivity that many films display, surprisingly few studies are devoted to the topic. Yifen Beus' article, "Authorship and Criticism in Self-Reflexive African Cinema," is the only study that examines the tendency in films by francophone African directors. ${ }^{57}$ Beus focuses on Fanta Régina Nacro's short Un Certain matin (1992), Abderrahmane Sissako's La vie sur terre (1998), and Mahamat-Saleh Haroun's Bye Bye Africa (1999). Beus contends that selfreflexivity functions in these films as a form of criticism, a critical stance toward the realities of filmmaking in Africa and toward the nature of cinema. This project expands upon the idea that self-reflexivity serves as a form of critique, and uncovers other aspects of self-reflexivity that go unexamined in her discussion. For instance, Beus does not consider references to other film directors, styles and movements in her approach to self-reflexive African cinema.

By emphasizing the importance of convergences that link films from Africa to films from France and America, this project aims, in part, to overcome forms of exceptionalism or oppositional criticism within African film studies. As Rachel Gabara observes, "scholars have tended to write about African film as if it existed in an odd sort of isolation, only reacting against

\footnotetext{
56 Adesokan, Postcolonial Artists and Global Aesthetics, see pages 108-132; Harrow, Postcolonial African Cinema, pages 140-162; Murphy and Williams, Postcolonial African Cinema, see pages 200-203; Lindiwe Dovey, African Film and Literature: Adapting Violence to the Screen (New York: Columbia University Press, 2009), see pages 205217; Matthias de Groof, "How Text Reflects Context: Representation of African Film Audiences in Aristotle's Plot," Journal of African Cinemas 5, no. 2 (2013): 181-202; de Groof, "Intriguing African Storytelling: On Aristotle's Plot by Jean-Pierre Bekolo," in Storytelling in World Cinemas Vol. 1 - Forms, ed. Lina H. Khatib (New York: Columbia University Press, 2012): 115-131; Jonathan Haynes, "African Filmmaking and the Postcolonial Predicament: Quartier Mozart and Aristotle's Plot," in Cinema and Social Discourse in Cameroon, ed. Alexie Tcheuyap (Bayreuth: Thielmann \& Breitinger, 2005): 112-136; Rachael Langford, "Re-Reading Migrancy in Film History, Form, and Genre: Bekolo's Le Complot d'Aristote/Aristotle's Plot (1996) and Kouyaté's Ouaga Saga (2004)," Transnational Cinemas 4, no. 1 (2013): 89-107.

${ }^{57}$ Yifen Beus, "Authorship and Criticism in Self-Reflexive African Cinema," Journal of African Cultural Studies 23, no. 2 (December 2011): 133-52. Liani Maasdorp examines self-reflexivity in contemporary South African documentaries. Maasdorp, "Looking In, Looking Out: The Self-Reflexive Mode of Representation in a Selection of Contemporary South African Documentary Films," South African Theatre Journal 25, no. 3 (November 2011): 20826.
} 
and rejecting the themes and styles of colonial and neocolonial European cinema rather than participating in international cinematic traditions. ${ }^{.58}$ However, Teshome Gabriel acknowledged affinities in Third Cinema with other cinematic movements across space and time in his important book Third Cinema in the Third World: The Aesthetics of Liberation.$^{59}$ Despite the specificity of Third Cinema's "need to go far beyond the concepts and propositions of traditional film forms," Gabriel writes, new developments in cinema do not take place in a vacuum. The influence of contemporary trends in cinema on Third Cinema is obvious. For instance, Third Cinema practitioners find a common bond with progressive or Left groups in America, Italy or France. Moreover, the Third Cinema continues to enrich itself with the theoretical and aesthetic concerns of contemporary film thought and scholarship. ${ }^{60}$

Even though Gabriel's work influenced African film scholarship substantially, critics have been wary to examine stylistic and aesthetic affinities among African films and other cinematic and artistic movements until recently.

In recent years, African film criticism has increasingly turned away from what David Murphy and Patrick Williams refer to as a form of exceptionalism. In their introduction to Postcolonial African Cinema: Ten Directors, they point out that, owing to the particular nature of African cinema's development, criticism has long been subject to exceptionalism, which has seen it occupy a space in between other, more established fields. ${ }^{61}$ Their volume attempts to overcome this sense of exceptionalism to reconsider directors and their works within the broader

\footnotetext{
${ }^{58}$ Rachel Gabara, “'A Poetics of Refusals': Neorealism from Italy to Africa," Quarterly Review of Film and Video 23 (2006), 201.

59 Teshome Gabriel, Third Cinema in the Third World: The Aesthetics of Liberation (Ann Arbor: UMI Research Press, 1982).

${ }^{60}$ Ibid., 3.

${ }^{61}$ Murphy and Williams, Postcolonial African Cinema, 18-20.
} 
fields of film studies, cultural studies, and postcolonial studies. In a similar vein, Alexie Tcheuyap argues for a move beyond oppositional criticism, a "scholarly disposition concerned with defining African cinema against other cinemas" (emphasis in original). ${ }^{62}$ In his book, Postnationalist African Cinemas, Tcheuyap locates aesthetic, generic and representational trends in a post-nationalist framework, although his inquiry does not consider evidence of other world cinematic legacies in francophone sub-Saharan African films. This project aims to avoid engaging in exceptionalism, by drawing on the broader field of film studies to examine African films in relation to film directors and movements in other parts of the world.

In seeking to overcome the scholarly trends outlined above, this project builds upon studies that explore traces of other cinematic legacies in francophone sub-Saharan African film. Noteworthy examples include Anny Wynchank's and Dayna Oscherwitz' works on Djibril Diop Mambéty, Rachel Gabara's study on Neorealism in African film, and Sada Niang's book on affinities between African films made during the "nationalist period" (1959-1973) and other cinematic movements in the world. ${ }^{63}$ These important studies effectively demonstrate that, as Niang states, "in style and content, African cinema has been part of world cinema since the beginning. $" 64$ Niang focuses on various ways films from the nationalist period, including those made by filmmakers who are generally considered leftist, militant, and/or didactic, "coasted, quoted, or even adopted the iconography of Italian neorealist, French New Wave, American

\footnotetext{
${ }^{62}$ Tcheuyap, Postnationalist African Cinemas, 26. Prior to the appearance of Tcheuyap's and Murphy and Williams' works, David Murphy asserted that the debate pertaining to "the nature of African cinema has too often been trapped within a reductive opposition between Western and African culture." Murphy, "Africans Filming Africa: Questioning Theories of an Authentic African Cinema," Journal of African Cultural Studies 13, no. 2 (2000), 241. 63 Anny Wynchank, Djibril Diop Mambéty ou le voyage du voyant (Ivry-sur-Seine: Éditions A3, 2003); Oscherwitz, "Of Cowboys and Elephants, 223-38; Gabara, “"A Poetics of Refusals"”; Sada Niang, Nationalist African Cinema: Legacy and Transformations (Lanham: Lexington Books, 2014).

${ }^{64}$ Niang, Nationalist African Cinema, 28-29.
} 
crime, gangster or British animation film aesthetics." ${ }^{65}$ Similar to Niang, scholars increasingly focus their attention on ways African filmmakers have drawn from the historical, institutional, and/or aesthetic practices of other cinematic movements. Gabara's study, for instance, considers the work of Ousmane Sembène as well as that of contemporary African filmmakers as a response to Roberto Rossellini and the Neorealist movement. Oscherwitz' article on Mambéty’s Hyènes shows how it borrows from the film genre of the western in form and iconography as a way to critique certain types of authoritative discourse stemming from American culture and the Western world. Also working on Mambéty, Wynchank highlights affinities between the Senegalese director and comedies from the silent-film era, and the French new wave. My first chapter adopts a similar approach to these studies by examining the prevalence of references to Charlie Chaplin and silent era in films spanning the roughly fifty years of African cinema's existence. Like the aforementioned studies, this chapter uncovers new cinematic affinities so as to further our view of African films as part of world cinema.

While it may seem counterintuitive to focus solely on African films and directors in order to achieve these ends, my approach does not intend to be reductive but to articulate significant ways that African cinema and other cinematic practices are entwined so that we may work towards writing a more comprehensive history of world cinema. Cultural materials do not only flow one way-that is, from Western contexts to Africa, as Heather Snell aptly points out. ${ }^{66}$ With respect to Touki Bouki, she writes, "Senegalese filmmakers, and Mambéty especially, synthesize received cultural materials to create something entirely new and, in the process, help to shape African and European cinema." ${ }^{67}$ Wes Felton demonstrates this point in his article on Paulin

\footnotetext{
65 Niang, Nationalist African Cinema, xvi.

${ }^{66}$ Heather Snell, "Toward a 'Giving and Receiving': Teaching Djibril Diop Mambéty’s Touki Bouki,” Journal of African Cultural Studies 26, no. 2 (2014), 131.

${ }^{67}$ Ibid.
} 
Soumanou Vieyra's Afrique sur Seine, in which he examines the influence of the French New Wave on francophone African filmmakers and vice versa. ${ }^{68}$ He questions both the absence of minorities in films by New Wave directors, and the exclusion of titles by African directors that display tendencies of the movement.

The first chapter of this dissertation, “'We All Belong to Chaplin': Charlie Chaplin and Silent Film in Francophone Sub-Saharan African Cinema," examines the prevalence of references to Charlie Chaplin and the silent mode over the course of francophone sub-Saharan African filmmaking. These references take the form of posters or other elements that visually signify Chaplin, as well as narrative and aesthetic strategies that borrow thematically and/or stylistically not only from Chaplin but also from the silent comedy genre for which he was famous. By making allusions to Chaplin, a popular figure who made commercial entertainment films for the masses, directors demonstrate that they are not just intellectual art house directors, but that they watched and loved the same movies as everyone else did when they were young. Bringing this fact into focus, I argue that it helps to reconcile the division between films for entertainment purposes and art films in African filmmaking practices. At the same time, Chaplin films constitute a significant personal cinematic memory for many directors, and in most cases viewing his films formed the basis of their representational universe. Through allusions to Chaplin and the silent era in francophone sub-Saharan African filmmaking, directors are staking a claim to a world cinema heritage, which shifts our understanding of African cinema and its place in the context of world film history.

The second chapter, "Screening Alternatives: A New Political Film Language," analyzes Jean-Pierre Bekolo's Les Saignantes (2005) and Balufu Bakupa-Kanyinda's Juju Factory (2007),

\footnotetext{
${ }^{68}$ Wes Felton, "Caught in the Undertow: African Francophone Cinema in the French New Wave," Senses of Cinema 57 (December 2010), http://sensesofcinema.com/2010/feature-articles/caught-in-the-undertow-africanfrancophone-cinema-in-the-french-new-wave/.
} 
two fiction films that explore subversive material in highly imaginative ways. While stylistically these films look nothing alike, they deploy a similar narrative and aesthetic strategy of enacting the process of making a film as a way to subvert or overcome certain types of authoritative discourse. In Les Saignantes, the primary narrative events of the film form an allegory of cinema; the death, dismemberment, bodily reconstitution and funeral wake of one of the male heads of state represents the different phases of film production. Performing the process of deconstruction and reconstruction in the fictional world of the film models the change needed in society. In Juju Factory, the manuscript the main character is writing over the course of the film comes to fruition at the end, creating a mise-en-abime with the film narrative. The writer-protagonist resists the restrictions imposed on him by his financial backer and successfully writes his own story, a model in the larger realm of African artistic production. Reading Juju Factory and Les Saignantes alongside one another brings out cinema's power to subvert and transform situations of dominance. This narrative and aesthetic strategy, I posit, articulates a new political film language in African cinema.

The third chapter, "Questioning African Cinema: Performativity in Bye Bye Africa and Lieux Saints,” examines films that address contemporary issues concerning African filmmaking and spectatorship, and question the future of the art form. Mahamat-Saleh Haroun's Bye Bye Africa (1999) is Chad's first feature-length film, and it blends fiction and documentary filmmaking strategies in its assessment of the present state of cinema in the country. The film primarily questions how to make films for Chadians from ideological and practical standpoints in order to envision a tradition of filmmaking in the country. In Jean-Marie Teno's most recent documentary, Lieux Saints (2009), the stakes remain similar; it, too, reflects upon the present and future of African cinema. In these films, respectively, Haroun and Teno both examine and enact 
the subjects they explore, and in this sense their films are reminiscent of performative documentary according to Stella Bruzzi's approach to the mode. The films' performative strategies correspond to their aim of seeking to define the future of African cinema. Instead of simply naming the inherent issues in filmmaking and spectatorship on the continent, both films put into practice a mode of representation that seeks to resolve the very issues that they name, at least in part. This mode of representation is distinct in each film; however, each involves the presence of the filmmaker. Redefining the future of African cinema inevitably entails reflecting on the filmmaker's role and, as I argue, each filmmaker displays an acute awareness of this, and suggests a new role for the African filmmaker.

This dissertation traces the self-conscious tendency in films by pioneers Ousmane Sembène and Djibril Diop Mambéty in an effort to further position African cinema in the context of international film history. Films by these and other African directors are informed by and draw on international traditions, but they are also aesthetically innovative. Formal experimentation and innovation, while visible in early works, especially those of Mambéty, becomes a defining factor of the films of a younger generation of African filmmakers. The films by Bekolo, Bakupa-Kanyinda, Haroun, and Teno in this project's corpus reveal a commitment to advancing African cinema aesthetically and conceptually. By reading their films together, we gain a collective effort at thinking through new directions in African cinema beyond what we might get from focusing on the work of a single director. 


\section{Chapter One}

\section{'We all belong to Chaplin': \\ Charlie Chaplin and Silent Film in Francophone sub-Saharan African Cinema}

"Le cinéma est universel parce que la perception visuelle à travers le monde varie moins que les idiomes. "-Christian Metz ${ }^{1}$

For brothers Tahir and Amine, the main characters of Chadian director Mahamat-Saleh

Haroun's second feature film, Abouna (2002), the cinema is not only a favorite pastime but also a place of surprising significance. ${ }^{2}$ The narrative revolves around their efforts to find their father who has vanished. One day the boys skip school and go see a movie. They are shocked to see their father on screen, acting in the film. They return to the movie house the following day to confiscate the film can containing the reels. Before breaking into the projection room, Tahir and Amine pore over the film posters that decorate the exterior, advertising Idrissa Ouedraogo's Yaaba (1989), Jim Jarmusch's Stranger than Paradise (1984), Issa Serge Coelo's Daresalam (2000), and Charlie Chaplin's The Kid (1921). ${ }^{3}$ Amine, the younger of the two boys and the one who struggles the most with their father's absence, lingers in front of the Chaplin film poster (figure 1). For viewers familiar with The Kid, the reference to the film evokes a strong narrative similarity, as both films deal with a parent abandoning his child or children, and confront themes of childhood, loss, abandonment, and hope. Beyond these parallels, Amine's pause in front of the poster for The Kid compels viewers to reflect on Haroun's affinities with the world-famous director from the early twentieth century. Born more than half a century later than Chaplin and in

\footnotetext{
${ }^{1}$ Christian Metz, Essais sur la signification au cinéma (Paris: Klincksieck, 1983), 69.

2 Abouna, directed by Mahamat-Saleh Haroun (Los Angeles, CA: Duo Films, 2002), DVD.

3 Amine tears the Daresalam poster off of the wall, a gesture that alludes to another film. Two young boys skipping school to go to the cinema, where they steal a movie poster, is a reference to François Truffaut's classic film Les Quatre Cents Coups (1959). Through this intertext with Truffaut's film and the inclusion of the film posters, Haroun stakes a claim on his status as a director and also acknowledges those who influenced him.
} 
an entirely different part of the world, Haroun proclaims the director as his "référence première. ${ }^{4}$ His love for Chaplin coincides with his deep appreciation for silent film, especially its ability to tell a story in a purely visual way. ${ }^{5}$ Sparse dialogue is indeed a defining characteristic of Haroun's films, notably Abouna, Darratt (2006), and Un homme qui crie (2010), where he makes use of other means to explore the character's inner sentiments and to tell the story. ${ }^{6}$ In a more recent interview in which Haroun explains his reasons for including the Yaaba poster in Abouna, Haroun posits Ouedraogo's film as an example of one that bears resemblance to Chaplin's style. "We all belong to Chaplin," he concludes.

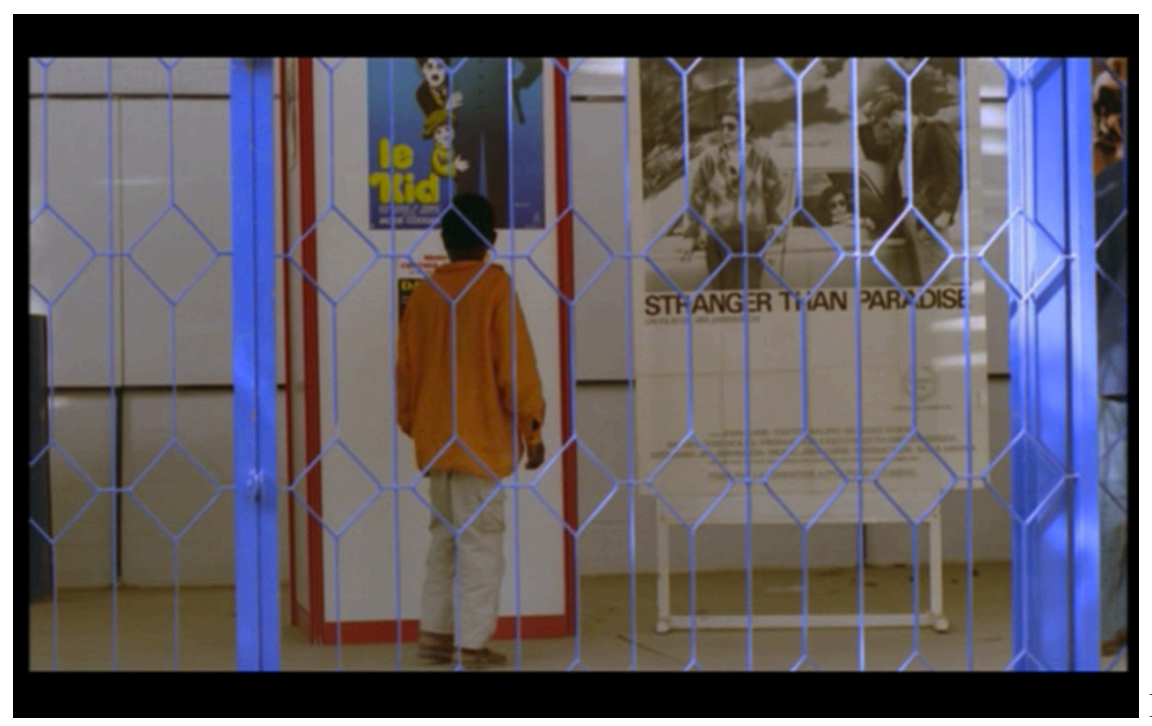

Fig. 1

Haroun is not the sole francophone sub-Saharan African filmmaker who demonstrates an affinity for Charlie Chaplin through allusions like the one in Abouna, or by deploying thematic, stylistic, or structural elements from Chaplin's work and the silent mode. In fact, allusions to Chaplin and the silent era are quite common in francophone sub-Saharan African film. Directors

\footnotetext{
${ }^{4}$ Olivier Barlet, “Abouna, Éloge du Respect. Entretien d'Olivier Barlet avec Mahamat-Saleh Haroun, Cannes mai 2002," Africultures, May 1, 2003, http://www.africultures.com/php/?nav=article\&no=2358.

5 Angela Dalle Vacche, "A Film is Trying to Build a Sort of Eternity: An Interview with Mahamet-Saleh Haroun," Senses of Cinema 47 (May 2008), http://sensesofcinema.com/2008/feature-articles/mahamet-saleh-haroun/.

${ }^{6}$ Darratt, directed by Mahamat-Saleh Haroun (New York, NY: ArtMattan Productions, 2006), DVD; Un homme qui crie, directed by Mahamat-Saleh Haroun (Fair Lawn, NJ: Film Movement, 2010), DVD.

7 Dalle Vacche, "A Film is Trying to Build a Sort of Eternity."
} 
from different generations and nationalities share their admiration for Chaplin in interviews, in visual quotations in their films, and borrow from his work to varying degrees. The Senegalese director Ousmane Sembène, who is often hailed the 'father of African cinema,' shows aesthetic tendencies reminiscent of Chaplin as well as ideological similarities that inflect his work thematically. He also directly cites Chaplin in his film Xala (1975). ${ }^{8}$ An equally prominent figure in African filmmaking and one who is known for his aesthetic adventurousness and ludic approach, the Senegalese director Djibril Diop Mambéty executes his film Badou Boy (1970) in the silent mode and even poses as Chaplin in one scene. ${ }^{9}$ More recently, the Congolese director José Zéka Laplaine stylistically executes his short film Le Clandestin (1996) in the silent mode, while Jean-Pierre Bekolo from Cameroon and Balufu Bakupa-Kanyinda from the Democratic Republic of the Congo borrow thematically and stylistically from Chaplin in Aristotle's Plot (Bekolo, 1996) and Le Damier (Bakupa-Kanyinda, 1996). ${ }^{10}$ Chaplin's artistic legacy is also a decisive factor in the trajectory of certain filmmakers, from their very decision to make films to shaping their individual film styles. In addition to Haroun, this is the case for Bakupa-Kanyinda, Fanta Régina Nacro, and Dani Kouyaté, while Idrissa Ouedraogo and Gaston Kaboré convey a deep admiration for the filmmaker in interviews. ${ }^{11}$

\footnotetext{
${ }^{8}$ Xala, directed by Ousmane Sembène (1975; New York, NY: New Yorker Films, 2005), DVD.

9 Badou Boy, directed by Djibril Diop Mambéty (1970; Rome: Raro Video, 2009), DVD.

${ }^{10}$ Aristotle's Plot, directed by Jean-Pierre Bekolo (1996; Paris: JBA Production, 2004), DVD; Le Damier - Papa National Oyé! (The Draughtsmen Clash), directed by Balufu Bakupa-Kanyinda (1996; New York, NY: ArtMattan Productions, 2000), DVD; Le Clandestin (The Stowaway), directed by José Zéka Laplaine. Cinémas d'Afrique (France: Centre National de Documentation Pédagogique, 2001), DVD.

${ }^{11}$ Fatou K. Sene, "Senegal: Balufu Bakupa-Kanyinda, cinéaste congolais: 'Tous mes films parlent de la grandeur de l'Afrique," AllAfrica.com, January 24, 2011, http://fr.allafrica.com/stories/201101241983.html; Zeinabou Gaoh, “Entretien avec Mme Fanta Régina Nacro, Réalisatrice Burkinabé," LeSahel.org, January 30, 2013, http://www.le sahel.org/index.php/component/k2 /item/2298-entretien-avec-mme-fanta-regina-nacro-realisatrice-burkinabe; Katarina Hedrén, "5 Questions for a Filmmaker-Dani Kouyaté," Africa is a Country (blog), October 29, 2014, http://africasacountry.com/5-questions-for-a-filmmaker-dani-kouyate/; "Chaplin Today: The Gold Rush," Chaplin Today, directed by Serge Le Péron. Disc 2. The Gold Rush, DVD, directed by Charlie Chaplin (Burbank, CA: Warner Home Video, 2003); Peter Vlam, "Gaston Kaboré on African Film," The Power of Culture, Sept. 2005, http://www.krachtvancultuur.nl/en/current/2005/September/kobore.html.
} 
Why are references to Charlie Chaplin and the silent mode consistently and increasingly prevalent over the course of francophone sub-Saharan African filmmaking? What does this trend reveal about African cinema, especially with regard to the context from which it emerged and its place within the larger scope of world cinematic traditions? This chapter will examine these questions by first investigating how viewing Chaplin films created a collective cinematic memory during the colonial period. This notion is foundational to grasping the significance of references to Chaplin and the silent mode in francophone sub-Saharan African film. By making allusions to Chaplin, a popular figure who made commercial entertainment films for the masses, directors demonstrate that they are not just intellectual art house directors, but that they watched and loved the same movies as everyone else did when they were young. Bringing this fact into focus, I argue that it helps to reconcile the division in African filmmaking practices so often alluded to by scholars, who contend that there is a clear-cut distinction between films for entertainment purposes and art films. At the same time, Chaplin films constitute a significant personal cinematic memory for many directors, and in most cases viewing his films formed the basis of their representational universe. Through allusions to Chaplin and the silent era in francophone sub-Saharan African filmmaking, directors are staking a claim to a world cinema heritage, which shifts our understanding of African cinema and its place in the context of world film history. ${ }^{12}$

The division of cinematic practices into a framework of First, Second and Third Cinemas persists in contemporary film criticism. According to this taxonomy, Third Cinema consists of films that function as instruments of socio-political change and consciousness-raising. Third Cinema practices developed out of theoretical texts and manifestoes written in the late 1960s and

\footnotetext{
12 My use of the term "world cinema" aims to emphasize the global scope rather than referring to a particular category of film.
} 
early 70s by filmmakers in Argentina, Brazil, and Cuba, in reaction to imperialism and other styles of filmmaking. Namely, it was distinguished against a big-budget, commercial, mainstream First Cinema, and an artistic, independent, auteur Second Cinema. African cinema is most commonly associated with Third Cinema, due to its proximity to the principles of contestation and political agendas laid out by Fernando Solanas and Octavio Getino. ${ }^{13}$ However, contemporary filmmaking practices by francophone sub-Saharan African directors reveal a departure from Third Cinema preoccupations in their engagement with form and aesthetics, leading some critics to re-evaluate this association. For instance, Rachel Gabara's chapter devoted to Abderrahmane Sissako explores the way his work transcends the opposition of Second and Third Cinemas. ${ }^{14}$ Re-thinking contemporary African cinema's association with Third Cinema would seem to constitute the subject Manthia Diawara's book, African Film: New Forms of Aesthetics and Politics, as his conception of a 'new wave' in African cinema demonstrates heightened concern with aesthetic over ideological qualities, although he does not speak in terms of these divisions in film criticism. ${ }^{15}$ Other studies that investigate ways francophone subSaharan African films transcend its traditional association with Third Cinema explore how filmmakers use certain genres and modes to produce a popular cinema, such as Alexie Tcheuyap's work on comedy and Carina Yervasi's study on Ouaga Saga. ${ }^{16}$ Yervasi defines the popular as an approach to representation that "appeals to and captures the attention of mass

\footnotetext{
${ }^{13}$ Fernando Solanas and Octavio Getino, "Towards a Third Cinema," in Rethinking Third Cinema, ed. Anthony Guneratne and Wimal Dissanayake (London: Routledge, 2003), 265-86.

${ }^{14}$ Rachel Gabara, "Abderrahmane Sissako: Second and Third Cinema in the First Person," in Global Art Cinema: New Theories and Histories, ed. Rosalind Galt and Karl Schoonover (Oxford: Oxford University Press, 2010): 320 33.

${ }^{15}$ Manthia Diawara, African Film: New Forms of Aesthetics and Politics (Munich: Prestel, 2010).

${ }^{16}$ Alexie Tcheuyap, Postnationalist African Cinemas (Manchester: Manchester University Press, 2011), pages $42-$ 67. He argues that the "apparent absence of the genre of comedy did/does not preclude the existence of the 'comedic' within African films," (ibid., 47); Carina Yervasi, "Ouaga Saga, Magical Realism, and Postcolonial Politics," Research in African Literatures 39, no. 4 (Winter 2008), 40-57.
} 
culture for its amusement and entertainment. ${ }^{, 17}$ I adopt this definition in my use of the term, and contend that Chaplin's films fit into the model of First Cinema with respect to their mass appeal, and mode of production. By tracing the evidence of Chaplin and the silent era over the course of francophone sub-Saharan African filmmaking, I argue that it is not only possible but productive to view African cinema as stemming from First Cinema.

In recent years, scholars have increasingly focused their attention on ways African filmmakers have drawn from the historical, institutional, and/or aesthetic practices of other cinematic movements. "Relationality was always embedded in the DNA of the auteurist tradition in African cinema, which was never simply face-to-face with itself but was always also in conversation with other traditions," Aboubakar Sanogo aptly notes. ${ }^{18}$ Works by Sada Niang, Rachel Gabara, Dayna Oscherwitz, and Anny Wynchank identify ways African films borrow from, and participate in, international cinematic traditions. ${ }^{19}$ This chapter expands upon these insightful studies by examining the different ways francophone sub-Saharan African cinema engages with Charlie Chaplin and the silent film, a director and mode of filmmaking that remains as of yet unexplored.

Locating African filmmaking tendencies within world cinema traditions can steer us away from engaging in limited thought processes. For instance, the presence of underprivileged and marginalized individuals in African films can be understood as stemming from Chaplin's tradition, rather than as an accurate representation of daily life in Africa. More broadly, this

\footnotetext{
${ }^{17}$ Yervasi, "Ouaga Saga," 43.

18 Aboubakar Sanogo, "Certain Tendencies in Contemporary Auteurist Film Practice in Africa," Cinema Journal 54, no. 2 (Winter 2015), 141.

${ }^{19}$ Sada Niang, Nationalist African Cinemas: Legacy and Transformations (Lanham: Lexington Books, 2014); Rachel Gabara, “A Poetics of Refusals': Neorealism from Italy to Africa," Quarterly Review of Film and Video 23, no. 3 (2006): 201-15; Dayna Oscherwitz, "Of Cowboys and Elephants: Africa, Globalization and the Nouveau Western in Djibril Diop Mambety’s Hyenas," Research in African Literatures 39, no. 1 (Spring 2008): 223-38; Anny Wynchank, Djibril Diop Mambéty ou le voyage du voyant (Ivry-sur-Seine: Éditions A3, 2003).
} 
chapter constitutes one component of my larger project, which aims to overcome forms of exceptionalism or oppositional criticism within African film studies. While it may seem counterintuitive to focus solely on African films and directors in order to achieve these ends, my approach does not intend to be reductive but to articulate significant ways that African cinema and other cinematic practices are entwined so that we may work towards writing a more comprehensive history of world cinema.

\section{Chaplin Films on African Screens}

The existing scholarship on the introduction of motion picture projection in Africa during the colonial period only mentions audiences' enthusiasm for Charlie Chaplin films in passing. Manthia Diawara and Nwachukwu Frank Ukadike discuss Africans' early contacts with the cinema by colonial governments, missionaries, anthropologists, and others who were involved in bringing cinema to African populations. ${ }^{20}$ Diawara notes the popularity of Chaplin in the context of discussions on films that were screened to colonial audiences, especially regarding the types of films that were believed by colonial officials to be a 'good' or 'bad' influence. ${ }^{21}$ Commercial entertainment films generally fell into the latter category. Diawara and Ukadike underscore various reasons these film pioneers struggled with the appropriateness of the genre, including the possibility of overshadowing the specially prepared films that were didactic or evangelical, the risk of depicting negative aspects of life in Europe and North America, and the belief that such

\footnotetext{
${ }^{20}$ Manthia Diawara, African Cinema: Politics and Culture (Bloomington: Indiana University Press, 1992); Nwachukwu Frank Ukadike, Black African Cinema (Berkeley: University of California Press, 1994). Melissa Thackway briefly mentions the introduction of film in West Africa by the French colonial regime: "As early as 1900, the Lumière brother's L'Arroseur arrosé was thus first publicly screened in Dakar and a number of cinemas showing imported films was set up in the French African colonies after the First World War," Melissa Thackway, Africa Shoots Back: Alternative Perspectives in Sub-Saharan Francophone African Film (Bloomington: Indiana University Press, 2003), 7.

${ }^{21}$ Diawara, African Cinema, 1.
} 
films were technically too advanced for African minds. Despite these fears and beliefs, Chaplin's films were commonly screened to colonial audiences throughout Africa.

The following accounts from Colonial Cinema, a periodical published quarterly by the British Film Institute, detail audiences' familiarity with and love of Chaplin in parts of the British Empire. Although directors' accounts, which I will discuss later, furnish evidence that they would likely have encountered Chaplin films via similar methods as those that were used by the British, evidence as to what films were shown in parts of French West and Central Africa (the AOF and AEF) is somewhat scarce. However, Chaplin's massive appeal in France, and works devoted to French film exhibition in the colonies support our view that Chaplin films were known and loved among populations in these areas, as well. This section traces first-hand accounts that indicate Chaplin's acclaim among African audiences from the late 1930s to the 1950s, a period in which film programs circulated widely throughout the French and Britishcontrolled regions. ${ }^{22}$ The examples in this section attest to the creation of a collective cinematic memory, a common reference that unites a culture or population. It confirms how directors encountered Chaplin, but also provides a basis for understanding the historical and cultural implications of directors' allusions to Chaplin.

Chaplin, or Charlot as he is lovingly referred to in French, was a favorite among filmgoers in France leading up to the First World War, continuing into the interwar period and lasting as late as the $1950 \mathrm{~s}^{23}$ His popularity in France matched or even exceeded his popularity in the United States in $1920 .{ }^{24}$ Benin-born critic and filmmaker Paulin Vieyra was schooled in

\footnotetext{
22 James E. Genova, Cinema and Development in West Africa (Bloomington: Indiana University Press, 2014 ), 42.

${ }^{23}$ Libby Murphy, "Charlot Français: Charlie Chaplin, the First World War, and the Construction of a National Hero," Contemporary French and Francophone Studies 14, no. 4 (September 2010), 421.

24 Uno Asplund, Chaplin's Films: A Filmography, trans. Paul Britten Austin (Newton Abbot: David and Charles, 1973), 10 .
} 
France where he regularly watched Charlie Chaplin films alongside his French classmates. ${ }^{25}$ Jean Rouch, a French filmmaker and anthropologist, recalls seeing all the Chaplin films during his childhood, from 1917-1933. ${ }^{26}$ In her study on the reception of Chaplin in France around the time of the First World War, Libby Murphy demonstrates that not only was he widely known and celebrated in France during this period, but that the French went so far as to "claim a monopoly on understanding Charlot." ${ }^{27}$ Given Chaplin's tremendous success in France, and the fact that the films that screened there were shown in the French empire, we can assume that his films were screened in the French-controlled regions of Africa. Without giving specific titles, James Genova writes that the films that played at the early cinematic venues in West Africa "came almost entirely from France and the United States and generally were consistent with those that the audience would have had access to had they been in Europe instead of West Africa." ${ }^{28}$ In another passage, he implies again that audiences in West Africa would have had access to Chaplin films: "more theaters were built in the 1930s and increasing numbers of Africans turned out to view the latest releases from France and Hollywood."29 The types of films that played throughout the French empire that were the most popular among colonial audiences were both French and American titles, explains Alison Levine. ${ }^{30}$ Levine's thorough study of the different measures implemented by the French Ministry of Colonies to control the types of films presented to colonial audiences has many parallels with the efforts of the British.

\footnotetext{
25 Françoise Pfaff, "Paulin Soumanou Vieyra: pionnier de la critique et de la théorie du cinéma africain," Présence Africaine 170, no. 2 (2004), 236.

26 “Jean Rouch: Biographie longue," Comité du Film Ethnographique, accessed Sept. 2, 2014, http://www.comitefilm-ethno.net/jean-rouch/biographie-longue.html.

27 Murphy, "Charlot Français," 432.

28 Genova, Cinema and Development, 25.

29 Ibid., 27.

30 Alison J. Murray Levine, Framing the Nation: Documentary Film in Interwar France (New York: Continuum, 2010), 76 .
} 
An early account that makes mention of African audiences' predilection for Chaplin in British-controlled parts of Africa is found in L. A. Notcutt and G. C. Latham's publication on the Bantu Educational Cinema Experiment, The African and the Cinema, from 1937. This report, which chronicles the introduction of a film program in East Africa, mentions that 'Natives' were fond of comedy and farce, especially films by Charlie Chaplin. ${ }^{31}$ As with the Bantu Educational Film Experiment, film programs throughout the British and French colonies revolved around instructional documentaries devoted to health, hygiene, agriculture, and other aspects of life, and were designed to 'teach' audiences. From 1942-1954, the Colonial Film Unit, a division of the British Film Institute, brought films to rural audiences in remote locales, and documented many aspects of the endeavor. Louis Nell, a cinematographer in the former protectorate northern Rhodesia, outlines what the mobile cinema program typically consisted of by $1948 .{ }^{32}$ The following passage from his article showcases the belief among those involved in the Colonial Film Unit that instructional films had to be couched within a mixed collection, one that included commercial entertainment films, in order to appease audiences.

A mobile cinema programme usually starts off with one or two amusing films, followed by an instructional film. The next film is usually something else of particular interest, not necessarily comedy [...] Out of ten reels, five might be classified as entertainment. Three would be really educational. Two would be general local-interest films, or specially prepared newsreels. In this way, the pill is sugar-coated. ${ }^{33}$

Nell's article goes on to highlight the type of entertainment films that are designed to "sugar-coat the pill," or make the propaganda more palatable, as it were. "Slapstick of the Charlie Chaplin

\footnotetext{
${ }^{31}$ L. A. Notcutt and G. C. Latham, The African and the Cinema: An Account of the Work of the Bantu Educational Cinema Experiment During the Period March 1935 to May 1937 (London: The Edinburgh House Press, 1937), 109.

${ }^{32}$ Louis Nell, "The Mobile Cinema in Northern Rhodesia," Colonial Cinema 6, vol. 2 (June 1948), 43-46.

${ }^{33}$ Ibid., 45.
} 
type is always popular," he observes. ${ }^{34}$ This is just one of numerous observations that acknowledge Chaplin's favor among audiences.

The articles in Colonial Cinema clearly indicate that despite the Colonial Film Unit's efforts to captivate audiences with educational documentaries, it was the Chaplin films that stood out. Indeed, in his article on film programs in Nigeria, Norman Spurr writes, "it was the Charlie Chaplin comedy, put in at the end of the programme, which stole the show, and not our instructional films. ${ }^{, 35}$ In the same vein, an article contributed by an African whose name is not mentioned demonstrates the fame of Chaplin among rural audiences in present-day Ghana: "And no village audience is satisfied until, at the end, they see some comic film, such as Charlie the Rascal. I often wonder if Charlie Chaplin knows how many ardent fans he has in the Gold Coast. ${ }^{36}$ When assembling film programs, members of the Colonial Film Unit had to consider the use of entertaining films such as Chaplin's as a way to gain leverage, even though their primary objective was to instruct. Spurr notes a common refrain heard at Colonial Film Unit meetings, one that evinces a clear awareness of Chaplin's resounding popularity among mobile cinema audiences: "Can't we finish off with a Charlie Chaplin?" ${ }^{\text {, }}$ In addition to the mobile cinema program, Chaplin films frequently graced the screen in movie theaters in Britishdominated regions, as well. For instance, in an anonymously written article on an African-owned cinema in the Gambia, the author observes, "Repetition is not unacceptable to [audiences], and one favourite whom they are prepared to see again and again is the inimitable Charlie

\footnotetext{
${ }^{34}$ Nell, "The Mobile Cinema," 45.

${ }^{35}$ Norman Spurr, "The Mobile Cinema Van is a New Weapon of Mass Education," Colonial Cinema 7, vol. 2 (March 1949), 9-10.

36 “The Mobile Cinema Van in the Villages," Colonial Cinema (March 1945), 12.

${ }^{37}$ Norman Spurr, "Coating the Pill," Colonial Cinema 9, vol. 1 (March 1951), 21-22.
} 
Chaplin. ${ }^{.38}$ Audiences' enthusiasm for Chaplin in British-controlled areas was a well-known fact. By 1957, he was considered a household name in West Africa, in "towns like Freetown, Accra, Kumasi, Lagos or Nairobi," and was also revered in South Africa. ${ }^{39}$

Chaplin's popularity clearly stretched throughout many parts of the African continent, but there is little indication in Colonial Cinema or other historical sources of the specific aspects of his films that audiences found so intriguing. This is undoubtedly because the concern was foremost with producing a didactic model and measuring its effectiveness as opposed to simply diffusing commercial entertainment films for the sake of audiences' enjoyment. One article in Colonial Cinema, however, identifies the slapstick humor as the main characteristic of Chaplin's films that pleased viewers. The passage, written in the context of the Gold Coast, depicts audiences' reactions to the final selection in the film program, typically a comedy.

This is usually an old, a very, very old Chaplin, and the fact that Charlie may fall down, or knock somebody else down, or get a pail of water thrown in his face, makes them roar with laughter. It is all silent with an interpreter and a record player. I have never seen people go so hysterical with laughter. This is what they like, and this is what we have to compete with. ${ }^{40}$

Spectators keenly enjoyed Chaplin's choice comic elements, as this passage makes clear. Even so, we must ask ourselves to what degree Chaplin films were loved simply because they were paired with far less amusing instructional documentaries. Since the latter were created according to the belief that spectators were intellectually inferior and uncivilized 'savages,' would not any sort of entertaining film have been well received for providing some welcome respite? While this

\footnotetext{
38 “An African-Owned Cinema in Bathurst, Gambia," Colonial Cinema 6, vol. 4 (December 1948), 77-78.

${ }^{39}$ J. Koyinde Vaughan, "Africa South of the Sahara and the Cinema," Présence Africaine 14-15 (June - Sept. 1957), 218; Ndugu Mike Ssali, "Apartheid and Cinema," in African Experiences of Cinema, ed. Imruh Bakari and Mbye B. Cham (London: British Film Institute, 1996), 95.

${ }^{40}$ George Noble, "Cameraman on the Gold Coast," Colonial Cinema 10, vol. 2 (June 1952), 37.
} 
must be true, to a certain degree, there are traits unique to Chaplin that explain how he became a significant part of the collective cinematic imagination and remains so more than half a century later. We have only to turn to directors' first-hand accounts to uncover these traits. It is important to keep in mind that directors first discovered Chaplin films as spectators. While they cannot speak for an entire population of the region of francophone sub-Saharan Africa, let alone of their respective nations, their accounts delineate specific qualities that help us to understand his significance in the context of the colonial period, as well as in the context of African filmmaking-his significance to audiences and directors alike.

\section{The Appeal of Chaplin's Silent Model}

The character traits directors from francophone sub-Saharan Africa celebrate in Charlie Chaplin's films pertain to the silent quality of his art. Chaplin's approach to acting and filmmaking was inextricably tied to the silent film genre. Even after the advent of the talkies, he opted to continue making silent films. He resisted the sound technology because he felt that it spelled disaster for his choice medium, pantomime; he feared that his characters would not survive the changeover. The Tramp, one of the most recognizable film characters of all time, even today, expressed his feelings in other ways than speech. Not only were his physical attributes-a bowler hat, a walking stick, a distinctly shaped moustache, baggy pants, and jumbo shoes that enabled his famous walk-familiar to audiences all over the world, his pantomimic expression simplified communication while still expressing subtle and complex sentiments.

On a basic level, Chaplin's favorable reception among colonial audiences was undoubtedly due, in part, to the silent quality. As a nonverbal mode of signification, silent films involve little to no language interpretation in order to be understood and appreciated. An 
interpreter would be helpful if a film had intertitles, otherwise only slight effort was required to comprehend the onscreen action. For Gaston Kaboré, a director from Burkina Faso who claims Charlie Chaplin as one of his favorite filmmakers, Chaplin's films "cannot be misunderstood.",41 On the one hand, we can read Kaboré's statement as referring to the silent quality of Chaplin's art and how it functions as a sort of lingua franca, a language that is universally understood. Given the great linguistic diversity among audiences in the African countries in which Chaplin films were screened, the silent aspect certainly contributed to the appreciation of his films.

Further, the absence of dialogue resonates in particular within the context of African filmmaking, where linguistic choices are neither simple nor innocent. They may be determined by-or selected in reaction to-several factors, including funding or production circumstances, audience, and even depictions of Africans from Western standpoints. A multiplicity of languages in the area labeled francophone has been and continues to be a complex reality. This is reflected in the fact that films funded by French cultural institutions (such as the French Ministry of Coopération, which began funding films in the region in 1963) are considered francophone, even if they are in Wolof, Dioula, Bambara, and so forth. The use of local West African languages as opposed to French may forgo a wider audience, but more faithfully represents one's cultural identity. Melissa Thackway briefly traces filmmakers' choices in this respect: "Francophone African filmmakers soon recognised that they could represent their own cultures and identities by using local languages in their works [... Since the early Sixties, therefore, the majority of Francophone African films reflect the region's true polyvocal linguistic make-up."42 The symbolic dimension of language choice applies to French, as well. In many films, the use of French often signifies the former colonizing power, or, in some cases, the political and cultural

\footnotetext{
${ }^{41}$ Vlam, "Gaston Kaboré on African Film."

${ }^{42}$ Thackway, Africa Shoots Back, 45.
} 
institutions of the postcolonial state. For instance, Ousmane Sembène's Xala decries aspects of post-Independence Senegalese society by drawing attention to neocolonialist attitudes, which are apparent in the languages spoken by certain characters. Manthia Diawara examines Sembène's linguistic choices-and, by extension, those of other African directors who use African languages-from the perspective of Hollywood or Western cinema. Using the example of Sembène's first feature entirely in Wolof, Mandabi (1968), Diawara observes how employing an African language is a means to counter or subvert stereotypical representations of Africans:

Sembène's use of an African language becomes all the more compelling if we place it in the context of film history and Hollywood, where Africans are still depicted as if they do not have a coherent language; as if "Mumbo Jumbo" is the lingua franca of all of Africa. From the Tarzan jungle films to Out of Africa (1985) and The Color Purple (1985), African languages are presented as some incoherent noise that only makes sense to the "savages" in the film. ${ }^{43}$

Sembène's later feature Camp de Thiaroye (1987) introduces a different set of language issues but that also entail the appropriation or subversion of a stereotype. ${ }^{44}$ The troops use a pidginized version of French, referred to as petit-nègre, to communicate with each other. This shared language was initially devised by the French army during World War I to facilitate communication with the tirailleurs sénégalais-a misnomer, for the soldiers were historically drawn from all of France's African colonies-but by the interwar period it came to connote inferiority in representations of colonial subjects. However, in Sembène's film, the shared use of petit-nègre is the mark of solidarité among the soldiers, according to Tsitsi Ella Jaji. She

\footnotetext{
43 Diawara, African Film, 43. Mandabi, directed by Ousmane Sembène (1968; New York, NY: New Yorker Films, 2005), DVD.

${ }^{4}$ Camp de Thiaroye, directed by Ousmane Sembène (1987; New York, NY: New Yorker Films, 2008), DVD.
} 
observes that it "facilitates communication across difference," and motivates religious tolerance in the camp and eventually political solidarity. ${ }^{45}$

There are undoubtedly a host of other factors that determine filmmakers' linguistic choices that have gone unexplored here, but through these examples we can see how the silent quality of Chaplin's films provide an alternative, and perhaps altogether refreshing, approach. In fact, Burkinabe director Dani Kouyaté, who deeply values Chaplin's ability to reach broad audiences without the use of dialogue, suggests that Chaplin's silent films offered a resolution to the persistent question of language. He states that Chaplin "should be an inspiration to today's filmmakers who are preoccupied with things like lack of resources or what language to shoot our films in." ${ }^{, 46}$ Here, Kouyaté implies that, beyond the absence of dialogue, the silent model of Chaplin's films orients his desire to tell a story with purely visual means. Chaplin's silent model also guides Mahamat-Saleh Haroun's approach, as mentioned at the beginning of this chapter.

A key feature that contributed to Chaplin's appeal on a global scale was his ability to transcend barriers of language, socioeconomic class, nationality, and cultural background. He represented the "very figure of humanity," writes Libby Murphy. ${ }^{47}$ To identify with Chaplin's characters on some level is a consistent trend in the favorable reception of his films, and the case of francophone sub-Saharan Africa is no exception. Chaplin's characters went much deeper than moral or comic types; they were "psychologically motivated individuals with whose predicaments, aspirations, and emotions the viewer could identify." ${ }^{48}$ In fact, Burkinabe director Idrissa Ouedraogo explains how, for him, the Tramp's affective qualities overshadowed every

\footnotetext{
${ }^{45}$ Tsitsi Ella Jaji, Africa in Stereo: Modernism, Music, and Pan-African Solidarity (New York: Oxford University Press, 2014), 203-4.

${ }^{46}$ Hedrén, "5 Questions for a Filmmaker-Dani Kouyaté."

${ }^{47}$ Murphy, "Charlot Français," 423. Murphy notes that the original quotation is by Jacques de Baroncelli, who is quoted in Jacques Chevallier. Charlie Chaplin: Dossier de documentation (Paris: Centre national de documentation pédagogique, 1978), 71.

${ }^{48}$ Miriam Hansen, Babel and Babylon: Spectatorship in American Silent Film (Cambridge, MA: Harvard University Press, 1991), 80.
} 
other characteristic; his remarks stem from his participation in an episode of Chaplin Today, a ten-part documentary series devoted to Chaplin's feature films.

What you remember most are all the moments of laughter, his rather bizarre walkunique, I would say. Also the fact that he was a 'little' man; he was like us-an adult, but at the same time he's a child. And I think that's what created a bond between me and Charlie Chaplin, and everyone of my age. Because in the Tramp, it's feelings that are most important, and feelings are universal. You don't see the skin color, you don't see any color. You don't see a white man. You see emotion. ${ }^{49}$

For Ouedraogo as well as his peers, being able to relate to features of Chaplin's character was central to why he became a significant figure for him. He felt an affinity for the film icon's childlike mannerisms as well as his expression of feelings and emotions, qualities that transcend skin color. Up until the first African films were made-films by Africans that featured Africansaudiences lacked an image with which they could identify. And, as Jean-Pierre Bekolo aptly puts it, "identification creates interest." ${ }^{, 50}$ By displaying affective qualities, Chaplin's character forged connections on a basic human level. As a result, this may have helped audiences to feel part of humanity in general, a feeling that was likely singular during the period of colonial rule. The notion of a shared humanity, exemplified by Chaplin, is significant to our understanding of filmmakers' allusions to Chaplin.

\footnotetext{
49 "Chaplin Today: The Gold Rush," Chaplin Today, directed by Serge Le Péron. Disc 2. The Gold Rush, DVD, directed by Charlie Chaplin (Burbank, CA: Warner Home Video, 2003). Unfortunately, the Chaplin Today series is dubbed in English (original version is in French).

${ }^{50}$ Referring to the colonial era, Bekolo points out that, due to the types of films screened to colonial audiences, "audiences didn't have an image to identify themselves with." As a result, he explains, they could not feel represented in the cinematic medium, or even made to feel they exist. He continues: "Like how kids like movies because there is another kid in them, Africans like movies because there are other Africans on the screen. Identification creates interest." Jean-Pierre Bekolo, interview by Anna V. Keefe, February 14, 2014, The University of Virginia, Charlottesville, VA.
} 
Like Idrissa Ouedraogo, many directors from francophone sub-Saharan Africa first encountered Chaplin's films as a child. Thus, he is linked to a particular time in one's lifechildhood, and also to an initial discovery of the cinema. In this way, allusions to Chaplin in their films may be nostalgic. Ousmane Sembène first discovered movies during his childhood at a movie house in Zinguinchor, his native city in the region of Casamance, Senegal. ${ }^{51}$ In an interview in which he outlines the key moments of his entire life, he mentions 1930, the year he first became acquainted with the cinema through three figures of American comedy: Chaplin, Keaton, and McCarey; he was hooked. ${ }^{52} \mathrm{~A}$ cinephile from the start, Sembène's love affair began with Chaplin. This is the case for several Burkinabe directors who were born decades after Sembène. In his commentary on Chaplin Today, Ouedraogo recalls his first memories of watching the Tramp at six or seven years old, around the time Burkina Faso gained its independence in $1960 .{ }^{53}$ Chaplin films were shown at the Catholic Church in his native town as part of a film program whose mission was primarily to evangelize the younger generation. ${ }^{54}$ For Dani Kouyaté, Chaplin's shorts comprise not only an early memory but his very first film memory. He recalls viewing them as a child in the 1970s: "There was a film club at the National Cinema Directorate of the Upper Volta... where they hosted film screenings for youth every Thursday morning. That's where I discovered silent film. ${ }^{, 55}$ Fellow Burkinabe director Fanta Régina Nacro explains that her viewing activities in ciné-clubs during her youth brought her to

\footnotetext{
${ }^{51}$ Samba Gadjigo, Ousmane Sembène: The Making of a Militant Artist, trans. Moustapha Diop (Bloomington: Indiana University Press, 2010), 42.

52 Ousmane Sembène, "Mes dates clés, par Ousmane Sembène," Libération, March 9, 2005, http://next.liberation.fr /cinema/2005/03/09 /mes-dates-cles-par-ousmane-sembene_512235.

53 "Chaplin Today: The Gold Rush," Chaplin Today, dir. Le Péron.

${ }^{54}$ Ouedraogo's anecdote gives narrative to the ways Chaplin films were projected that I explored in the previous section. The timeline of Ouedraogo's and Kouyaté's accounts suggest that the pairing of Chaplin films alongside instructional or evangelical films continued even after the end of colonization.

${ }^{55}$ Hedrén, "5 Questions for a Filmmaker-Dani Kouyaté."
} 
become a director. ${ }^{56}$ The films she recalls watching there were Charlie Chaplin's and westerns. In a distant part of the continent, viewing Chaplin's films was also a memorable and significant childhood activity for Balufu Bakupa-Kanyinda. The director from the Democratic Republic of the Congo refers to watching Chaplin films at his house while growing up as an "education." This is what led him to his "vocation for the cinema," he states in an interview. ${ }^{57}$ As part of their early (or earliest) viewing activities, Chaplin films formed the basis of their representational universe.

If Chaplin is linked to a specific period or moment in the lives of certain francophone sub-Saharan African directors, he is also tied to an era of filmmaking-one that was silent and in which relatively few techniques were used, partly because they had not been invented yet. Dani Kouyaté and Idrissa Ouedraogo share their admiration for all that Chaplin accomplished with great technical simplicity. In fact, Kouyaté proclaims Chaplin as his primary reference, and the silent era as the "belle époque du cinéma," for the absence of dialogue, the basic technical aspects, the profoundly human emotional aspect, and the timeless quality. ${ }^{58}$ When asked by Jean Ouédraogo if he has idols in the world of cinema, and who the directors are that he seeks to emulate, Kouyaté responds:

Moi, j'ai toujours une référence au cinéma. C'est Charlie Chaplin. Pour moi, c'est la référence. Au delà de la personne de l'artiste Charlie Chaplin, c'est l'impression de toute une époque. Pour moi, le cinéma muet c'était la belle époque du cinéma, l'époque intelligente du cinéma si je peux ainsi dire parce que pour moi, des gens comme Chaplin, ils ont fait rire et fait pleurer le monde entier sans parler et avec des moyens très simples. C'était une caméra parfois qui ne roulait même pas avec quatre images seconde, c'était

\footnotetext{
${ }^{56}$ Gaoh, "Entretien avec Mme Fanta Régina Nacro, Réalisatrice Burkinabé."

${ }^{57}$ Sene, "Senegal: Balufu Bakupa-Kanyinda, cinéaste congolais."

${ }^{58}$ Ouédraogo, "Extraits d'un entretien avec Dani Kouyaté."
} 
sur pied, il n'y avait aucune grue, aucun travelling, rien de tout cela: il n'y avait aucun mouvement sophistiqué de caméra. C'était très basic, mais c'était très fort et c'était très émouvant et c'était très humain. Pour moi, c'était la période humaine du cinéma et il y a encore des classiques qui sont encore d'actualité aujourd'hui, des films comme Les temps modernes. C'est un classique extraordinaire. Parfois, j'ai l'impression qu'aujourd'hui on est parti trop loin, on est parti tellement loin qu'on a oublié que le cinéma c'est une histoire d'Hommes avant tout. ${ }^{59}$

Kouyaté's deep sentimentality for the type of filmmaking from Chaplin's era is matched with a sense of disillusion for contemporary filmmaking trends. Without having lived during the period, Kouyaté is wholly nostalgic about it and its characteristics.

Idrissa Ouedraogo echoes the idea that the silent era is the intelligent age of cinema by relating his admiration for the "ingéniosité" of Chaplin and his team. He also seconds Kouyaté's criticism for cinema today. As part of his participation in the Chaplin Today series, he provides commentary on a scene from Chaplin's feature The Gold Rush. He dissects one moment in which it appears as if Chaplin is running on an invisible treadmill, and discusses how Chaplin was able to achieve this effect. He then comments on the means of filmmakers at that time compared to the present: "What do they have? There's no modern stuff like computers, but they manage to do extraordinarily fantastic things. There was real thought going into the cinema then, whereas

\footnotetext{
${ }^{59}$ Ouédraogo, "Extraits d'un entretien avec Dani Kouyaté." "I still have a single reference in cinema and that is Charlie Chaplin. For me, it's the reference. Beyond the individual artist Charlie Chaplin, it is the impression of an entire era. For me, silent film was the golden age of cinema, the intelligent age if you will, because people like Chaplin made the whole world laugh and cry without speaking and with very simple means. Sometimes the camera didn't go beyond four images per second, it was on a tripod, there was no crane, no tracking shots, none of that; there were no sophisticated camera movements. It was very basic, but very powerful, very moving and very human. For me, it was the most human period of cinema and some of its classics remain pertinent even today, such as Modern Times, which is an extraordinary classic. Sometimes I get the impression that we have taken things too far, so far that we have forgotten that the cinema is a history/story of mankind, first and foremost." (My translation)
} 
today movies have become a mere combination of money and very expensive special effects."60 On one hand, Ouedraogo's and Kouyaté's remarks may stem from the context of African filmmaking, where dealing with few material means has long been a complex reality. Since its inception, Francophone African filmmakers have faced working with low-level budgets, and reliance on France for funding, crews, and technical support (for post-production), among other issues. ${ }^{61}$ This context may factor into their acknowledgement of the ingenuity of Chaplin and his contemporaries, to some degree. On the other hand, do not all filmmakers, let alone artists, strive to create something that will stand the test of time? Kouyate states that Modern Times is today “more relevant than ever." ${ }^{62}$ Moreover, a moment in Chaplin Today (from 2002) illustrates the timeless appeal by showing a group of kids in Ouedraogo's hometown watching a Chaplin film for the first time. A series of close up shots on individual children's faces shows them smiling and laughing, very engrossed in the film, as Ouedraogo's comments play in voice-over. ${ }^{63}$

This episode from Chaplin Today explores The Gold Rush, which focuses on a poor man's dream of making a fortune. If not for the fact that he is one of the most famous directors from francophone West Africa, Ouedraogo was likely selected to provide commentary because his short film Obi (1991) borrows thematically from The Gold Rush by centering on the subject of gold mining in Burkina Faso. Additionally, if we recall Mahamat-Saleh Haroun's observation mentioned at the beginning of this chapter, he posits that Yaaba, perhaps Ouedraogo's most well-

\footnotetext{
60 "Chaplin Today: The Gold Rush," Chaplin Today, dir. Le Péron.

${ }^{61}$ For discussions on French aid, see Roy Armes, African Filmmaking North and South of the Sahara (Bloomington: Indiana University Press, 2006), 53-64, and Teresa Hoefert de Turégano, African Cinema and Europe: Close-Up on Burkina Faso (Florence: European Press Academic Publishing, 2004), 75-119. For consideration of the difficulties relating to equipment, technicians, budget, and production, see Olivier Barlet, Les Cinémas d'Afrique: le regard en question (Paris: L’Harmattan, 1996), 239-51.

${ }^{62}$ Hedrén, "5 Questions for a Filmmaker-Dani Kouyaté."

63 "Chaplin Today: The Gold Rush," Chaplin Today, dir. Le Péron.
} 
known film, "looks like a film made under Chaplin's influence." ${ }^{64}$ Ouedraogo's participation in the Chaplin Today series inherently indicates a strong connection between him and Chaplin. Somewhat surprisingly, Kouyaté's films do not include striking allusions to Chaplin or to the silent film genre. Nevertheless, there are many allusions to Chaplin and his era that are either thematic, stylistic, or structural in francophone sub-Saharan African films, beginning with its filmmaking pioneer, Ousmane Sembène.

\section{Sembène's Affinities with Chaplin}

Ousmane Sembène rarely mentioned his influences as a filmmaker, but he had the chance to meet Chaplin during his lifetime, an encounter that was "capital." ${ }^{, 65}$ When asked by Pierre Haffner if other filmmakers taught him anything, Sembène replied:

Il y en a un que j'ai eu la chance de rencontrer, un très vieux, Charlie Chaplin; il m'a dit que ce métier tout le monde pouvait le faire, mais qu'il exigeait beaucoup. Je crois que c'était à Londres, après l'histoire de McCarthy, bien avant que je fasse du cinéma, j'étais là-bas pour une conférence syndicale, j'étais encore loin du cinéma [...] C'est le seul type qu’on ne voyait ni dans les bistrots, ni dans les boîtes de nuit, ni dans les réceptions, il m'a dit qu'il fallait rester chez soi et travailler. ${ }^{66}$

\footnotetext{
${ }^{64}$ Dalle Vacche, "A Film is Trying to Build a Sort of Eternity."

65 “Ousmane Sembène: l'œil doit entendre," L'OBS.com, May 16, 2005, http://tempsreel.nouvelobs.com/culture /20050516.OBS6805/ousmane-sembene-1-oelig-il-doit-entendre.html.

${ }^{66}$ Pierre Haffner, "Sembène Ousmane à Kinshasa," Recherche, Pedagogie et Culture 37 (1978), 45. "There was one, an old man whom I had the fortune to meet very old, Charlie Chaplin; he told me that everyone could do this job, but that it is very demanding. I think that was in London, after the story with McCarthy, well before I got into cinema. I was over there for a trade-union conference; I was still far from cinema... He was the only guy who you couldn't see in bars, nightclubs, or at receptions. He told me one had to stay at home and work." English version in Ousmane Sembène: Interviews, ed. Annett Busch and Max Annas. Trans. Anna Rimpl and Annett Busch (Jackson: University Press of Mississippi, 2008), 90.
} 
When he met Chaplin, Sembène was an activist for workers' rights for the Confédération générale du travail, CGT. It is not surprising that Chaplin's workhorse mentality clearly had an effect on Sembène, who was anything but idle. Aside for his prolific career, his biographer recounts an illuminating example where Sembène, while shooting what would be his last film, Mooladé (2004), fainted on set. Seventy-nine years old at this point, he "categorically refused to suspend the shooting, churlishly retorting to those who advised him to take a break and refill his batteries, 'I'll have all the time needed to rest after my death." ${ }^{, 67}$ Sembène's firm dedication to work was informed from his days spent as a dockworker in Marseilles, a construction hand, a mechanic, and an infantryman in World War II. Thanks to these and other formative experiences he learned the values inherent in work. In this vein, Gadjigo writes that what mattered to Sembène "is the contribution each of us brings toward the well-being of all [...] For Sembène, there is nothing nobler than a willingness to make oneself useful to the community. But when individuals want to exploit this community work for their own gains, one must always take a principled stance against that." ${ }^{\text {,68 }}$ Here we get a glimpse of Sembène's belief in Marxism, a principle that permeates his works. In addition to an emphasis on the value of work, Sembène certainly appreciated many of Chaplin's values, Marxist or otherwise.

Sembène's admiration for Chaplin influenced his formal style, and relates to his overall artistic conception of seeking to "foster political debate through an activist approach to cinema," as David Murphy and Patrick Williams write. ${ }^{69}$ This approach is often articulated through Sembène's concept of cinema as an école $d u$ soir, dedicated to the cultural and political education of his people. Whereas Sembène's aesthetic practices were more cinematic than

\footnotetext{
${ }^{67}$ Gadjigo, Ousmane Sembène, 107.

68 Ibid., 47.

69 David Murphy and Patrick Williams, Postcolonial African Cinema: Ten Directors (Manchester: Manchester University Press, 2007), 68-69.
} 
Chaplin's, whose mises-en-scène evoke a theatrical production, each director's use of cinema's basic components, such as camera placement, mise-en-scène, and shot duration, tends to prioritize the narrative events, and dialogue in the case of Sembène. ${ }^{70}$ Moreover, the two filmmakers prize the social function of art, a quality that inflects their aesthetic choices. They infuse their films with social commentary and political ideology- strategies designed to transform the larger social and political order.

These ideological similarities also bear on Sembène's films thematically. Sembène, like Chaplin, was devoted to portraying the realities of the working-class on the screen. This explains the omnipresence of certain character types and themes, as they correlated to the everyday lives of the poor. Beginning with his first film, Borom Sarret (1963), which follows the daily activities of a cart driver from the poor part of town, Sembène demonstrates a strong dedication to the struggles of the lower socioeconomic classes. ${ }^{71}$ The cart driver experiences poverty, class discrimination, and lacks identity papers; these were among the issues that many Senegalese faced in newly postcolonial society. Sembène's deep commitment to the fight for sociopolitical change was informed by Chaplin's own loyalty to the lowly, to a certain degree.

On a related note, Sembène's choices were firmly rooted in the notion of filmmaking for an audience, which aptly characterizes his main reason for using cinema over literature. He stated countless times that he favored films due to ongoing widespread illiteracy; films could reach broad masses. Acknowledging the "value of direct contact with those on whose behalf his films are made," as Teshome Gabriel writes, Sembène deployed mobile projectors in remote

\footnotetext{
${ }^{70}$ In this vein, Kenneth Harrow reads the basic narrative structure of Sembène's films as "Hollywoodian," since they follow the "pattern of establishing a problem, followed by a false solution, and then ending with a real solution." Harrow, Postcolonial African Cinema: From Political Engagement to Postmodernism (Bloomington: Indiana University Press, 2007), 8.

${ }^{71}$ Borom Sarret, directed by Ousmane Sembène (1963; New York, NY: New Yorker Films, 2000), VHS.
} 
areas, as a way to reach populations who otherwise did not have access. ${ }^{72}$ Gabriel also notes how, in addition to circulating around the countryside with projectors, Sembène often took a Polaroid camera with him and would "invite people who marvel at the motion picture camera to try out the Polaroid themselves," as a way to demystify cinema. ${ }^{73}$

In his feature Xala (1975), a film that offers a vivid portrayal of postcolonial society and its ills, Sembène directly cites Chaplin. The film's female characters symbolize various tenets of Sembène's ideology; for instance, Rama embodies aspects of Pan-Africanism. The daughter of El Hadji, Rama is a modern woman who represents the director's hopes for the future; she speaks Wolof, goes to University, denounces polygamy, and admires African political heroes, such as Samory Touré and Amilcar Cabral. Iconography, in the form of posters, photographs and maps, functions significantly throughout the film by depicting certain characters with an individual or idea. A striking example is in Rama's bedroom, where in one shot we see a poster of Cabral and an almost life-size poster of Chaplin, dressed as the Tramp (figure 2). Since the central focus of Xala is to critique neocolonialism, the image of Cabral, the independence leader of Guinea-Bissau, does not seem out of place. The Chaplin poster is more surprising. Even though the length of the shot does not disrupt the flow of the sequence, the shot stands out because it is visually striking. The poster occupies a central place in the shot, in its dimensions and in its position in the center of the frame. First, the Chaplin image gives more insight into the character of Rama, since it is associated with her. It exemplifies the fact that she is a modern woman who incorporates aspects of Western culture into her daily life to the extent to which they can serve her. Françoise Pfaff highlights this idea, but only mentions education and technology

\footnotetext{
72 Teshome Gabriel, Third Cinema in the Third World: The Aesthetics of Liberation (Ann Arbor: UMI Research Press, 1982), 24.

${ }^{73}$ Ibid.
} 
as elements of Western culture that are useful to Rama. ${ }^{74}$ Why not the cinema? Her poster, its size, and place in the center of the shot, implies not only that she is familiar with film culture, but also that it is significant to her.

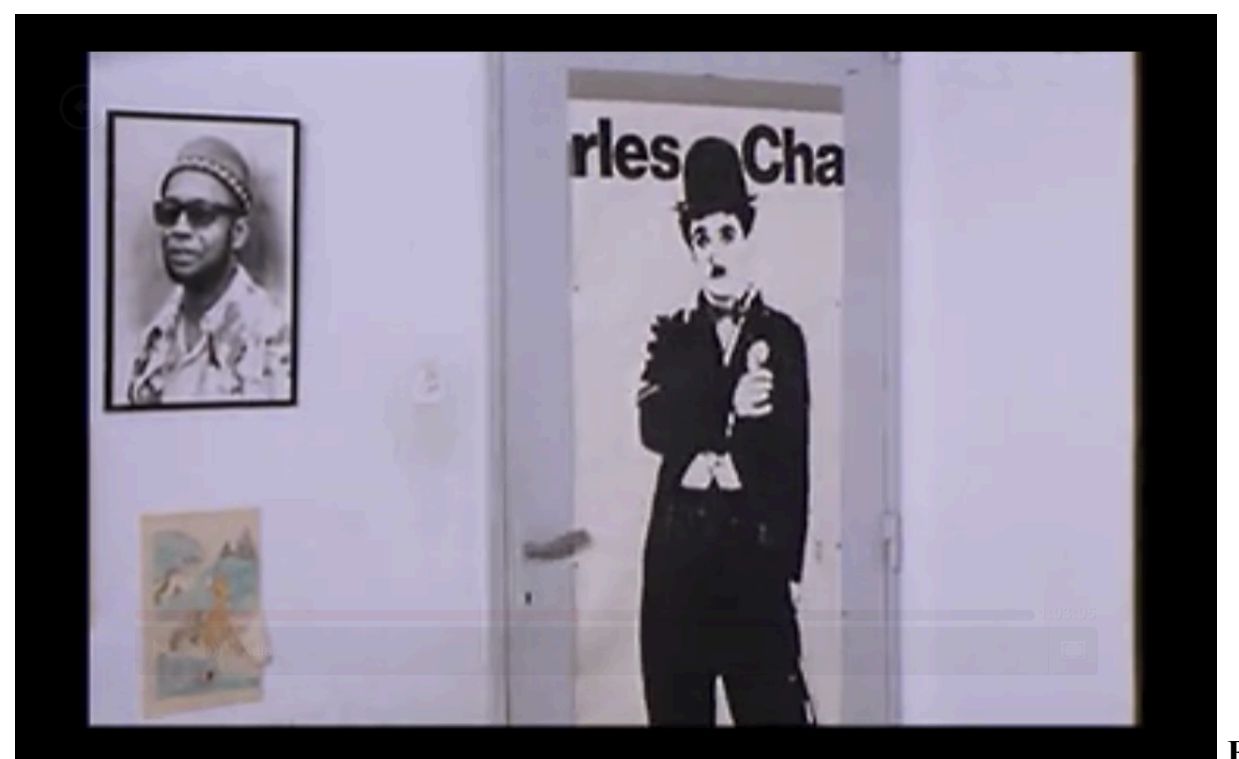

Fig. 2

The poster is an intertextual element that places the film in dialogue with the fictional world of Chaplin. Intertextuality is understood here, following Robert Stam's discussion of Gérard Genette and Julia Kristeva, as "the relation of effective co-presence of two texts in the form of quotation, plagiarism, and allusion." ${ }^{, 75}$ The poster foregrounds his work's relation to Chaplin's, since the image of the Tramp signifies Chaplin's primary character and, by extension, his fundamental paradigm, rather than one film in particular. Across Chaplin's films, the 'little guy' represents the underprivileged, the marginalized, and the downtrodden, while poking fun at bearers of wealth, authority, and a wide range of situations. Wrapping a political message in a comedy or in comic elements is emblematic of Chaplin's approach. This approach equally applies to Sembène's cinema, and it is most pronounced in Xala, which was his biggest

\footnotetext{
${ }^{74}$ Françoise Pfaff, "Three Faces of Africa: The Women in Xala," Jump Cut: A Review of Contemporary Media 27 (1982), 28.

${ }^{75}$ Robert Stam, Reflexivity in Film and Literature: From Don Quixote to Jean-Luc Godard (New York: Columbia University Press, 1992), 23.
} 
commercial success in Africa. ${ }^{76}$ The image thus affirms the multiple resonances in Sembène's work with Chaplin's on aesthetic and thematic levels, and also in his approach to the medium as meant for the masses.

Additionally, as a self-reflexive aspect, the poster draws our attention to Sembène's authorial presence, and situates him within the broader scope of film history. Josef Gugler observes that the poster pays homage to Chaplin, and writes: "Sembène claims his heritage as film director and as the advocate of the little man." 77 Gugler does not delve further into the notion of film heritage, although his remark underscores Sembène's artistic legacy from Chaplin. Indeed, Sembène claims a world cinema heritage. This heritage extends beyond the bounds of Third Cinema practices-practices with which he is most often associated-and includes connection to a style exemplified by a Hollywood filmmaker. This aligns him with First Cinema practices, according to which cinema is foremost a popular means of entertainment. Studies that identify Sembène's cinematic heritage in relation to other cinemas or cinematic movements, such as Rachel Gabara's and Josephine Woll's, trace similarities in his stylistic approach to cinema as a means to convey socio-politically engaged stances. ${ }^{78}$ My investigation of Sembène's affinity for Chaplin also reveals a similarity in their approaches to the medium, yet this comparison emphasizes that the popular is as important as, if not crucial to, the articulation of ideology in Sembène's cinema.

\footnotetext{
${ }^{76}$ Murphy and Williams, Postcolonial African Cinema, 52.

77 Josef Gugler, African Film: Re-Imagining a Continent (Bloomington: Indiana University Press, 2003$), 134$.

78 Rachel Gabara, “A Poetics of Refusals': Neorealism from Italy to Africa,” Quarterly Review of Film and Video 23 (2006): 201-15; Josephine Woll, "The Russian Connection: Soviet Cinema and the Cinema of Francophone Africa," in Focus on African Films, ed. Françoise Pfaff (Bloomington: Indiana University Press, 2004): $223-40$. Gabara identifies Sembène's realism as stemming from Italian Neorealism via the New Latin American Cinema. She shows that Sembène "has accomplished the goals set forth by Latin American filmmakers in an art without the "artlessness" of Neorealism. Unlike the Latin Americans, however, who fictionalized documentary, he has documentarized fiction and avoided the documentary genre" (ibid., 211). Woll draws conceptual and formal connections between Soviet cinema and the films of Sembène with respect to function (to promote ideology), style (such as the use of nonprofessional actors and character types), and aesthetics (camera placement, mise-en-scène, etc.) (ibid., 232-37).
} 
The Chaplin image in Xala also elicits an active response in spectators. In this vein, Vlad Dima asserts that the poster functions as "a subversive signifier" due to Chaplin's known affiliations with the Communist Party. ${ }^{79}$ The strategy of solicitation or engagement-seeking to inspire subsequent debate and/or action on the part of spectators-most frequently relates to the sociopolitical dimension of Sembène's work, but it could also communicate his wish for all of his compatriots to be familiar with and learn from the cinematic medium. Sembène felt the need for African countries to have a developed cinematographic culture, an idea he explains in his interview with Haffner:

Pour moi c'est un problème d'esthétique, il faut prendre le raccourci de l'histoire [...] Il y a des voitures qu'on dit tropicalisées ou adaptées aux pays africains, mais les principes du moteur sont les mêmes, de même pour la camera et les grands tournages, il reste la sensibilité d'un public qui aime bien le grand cinéma, qui nous a apporté quelque chose, l'ignorer, serait fuir, je dis donc: connaissons les classiques du cinéma mondial, nous y gagnons! $!^{80}$

For Sembène, audiences must be familiar with the medium, the cinematic codes, in order to understand what they are seeing. Their awareness of cinematic styles and traditions from different eras and countries can only benefit Sembène and other African filmmakers. In his follow-up remarks, Sembène acknowledges that it is still too early for the general public to be familiar with "the classics of world cinema," and that one of the tasks facing filmmakers and critics, such as Georges Sadoul, is to know them and to act as intermediaries between cinema and

\footnotetext{
${ }^{79}$ Vlad Dima, "Ousmane Sembene's La Noire de...: melancholia in photo, text, and film," Journal of African Cultural Studies 26, vol. 1 (2014), 60.

${ }^{80}$ Haffner, "Sembène Ousmane à Kinshasa," 45. "For me it is a question of aesthetics, it is necessary to take the short cut of history [...] Some cars are, so they say, tropicalized or adapted to African countries, but the principle of the engine is the same, and so it is with the camera and great filming. It relies on the sensitivity of a public who loves the big cinema and contributed something to us. To ignore it would mean to escape, so I say: we can only gain from knowing the classics of world cinema!” In Busch and Annas, Ousmane Sembène: Interviews, 89.
} 
the public. This idea relates to the didactic aim of his work, and draws out his commitment to the cultural education of his people.

Finally, the reference to Chaplin in Xala also evokes a significant period in Sembène's life, before he began making films. Sembène met Chaplin in London during a trade-union conference, at a time when he was an activist for workers' rights for the $C G T$ and was very politically active. Xala is clearly a political film in its scathing depiction of the system of postcolonial governance. His allusion to Chaplin is, therefore, also a nod to his earlier days as a dockworker when he was just starting out to battle injustices. Going back even further to his younger years of sneaking in to see movies, this period pre-dated his fight for socio-political causes, and revolved around his enjoyment of going to the cinema. Thus, Chaplin is linked to his memories of childhood, a happier, more innocent time in his own personal life. His allusion is imbued with nostalgic undertones, which sheds a new light on Sembène; while incontestably a militant artist, he was also a cinephile, and an avid consumer of popular films. If we can view him thus and as part of world filmmaking traditions, it places him and his works in a broader context.

\section{Mambéty and Chaplin: Humorous Critiques and Visions of Humanity}

Chaplin also had a significant impact on Djibril Diop Mambéty, Sembène’s compatriot and fellow filmmaking pioneer. Mambéty was active in the ciné-clubs in Dakar, where he would have encountered Chaplin films. A devoted cinephile, he was one of the club organizers, as Anny Wynchank writes: “Ayant fait partie des animateurs du Ciné-Club de Dakar, Djibril avait pu voir les classiques français et américains qui passaient dans le circuit, les films muets de Charlie 
Chaplin." ${ }^{, 81}$ Largely due to his viewing activities at the ciné-clubs, Mambéty became familiar with international film styles and traditions, which influenced him as a director. Unlike many African directors who studied at film school in Paris or Moscow, Mambéty did not do training abroad. In fact, he never had formal film training. His highly original filmmaking style involves an eclectic mix of narrative and aesthetic strategies; this is evident from the beginning of his career. His second feature, Badou Boy (1970), incorporates stylistic and thematic elements from Chaplin's work.

Badou Boy is a silent film that draws a parallel to Chaplin and his era. Aside for voiceover narration, dialogue is absent in the film. The characters appear to talk, but frequently there is no voice-over dialogue; their looks, postures and gestures are the viewer's only indication of what they are saying. The film's title character is a hooligan whose imprisonment would help everyone, even his mother, according to the film's voice-over narration, which is done by Mambéty. After stealing from his mother at the beginning of the narrative, Badou Boy roams around the city. He strolls, hops on a horse and engages in a race reminiscent of a stagecoach chase in a western, consistently evades a policeman, and craftily steals his friend, Moussa's job on a car rapide. ${ }^{82} \mathrm{Al}$ Demba, a heavyset officer on a bicycle, chases the young man over the course of the film, and narrowly misses catching him at the end. He has the young man in his clutches while standing next to Moussa. Moussa takes a swing at Badou Boy, but he quickly ducks and strikes the policeman instead. Badou Boy bowls over with laughter while the policeman takes off running after Moussa. This comic sequence illustrates the playful and light-

\footnotetext{
${ }^{81}$ Wynchank, Djibril Diop Mambety, 17. "Having been one of the organizers of the Ciné-Club of Dakar, Djibril would have seen French and American classics that circulated at the time, the silent films of Charlie Chaplin." (My translation)

${ }^{82}$ A car rapide is a hybrid vehicle between a van and a bus that transports passengers around the city.
} 
hearted tone of the film, and the trick is highly reminiscent of a slapstick gag that Chaplin performs numerous times in The Floorwalker (1916). ${ }^{83}$

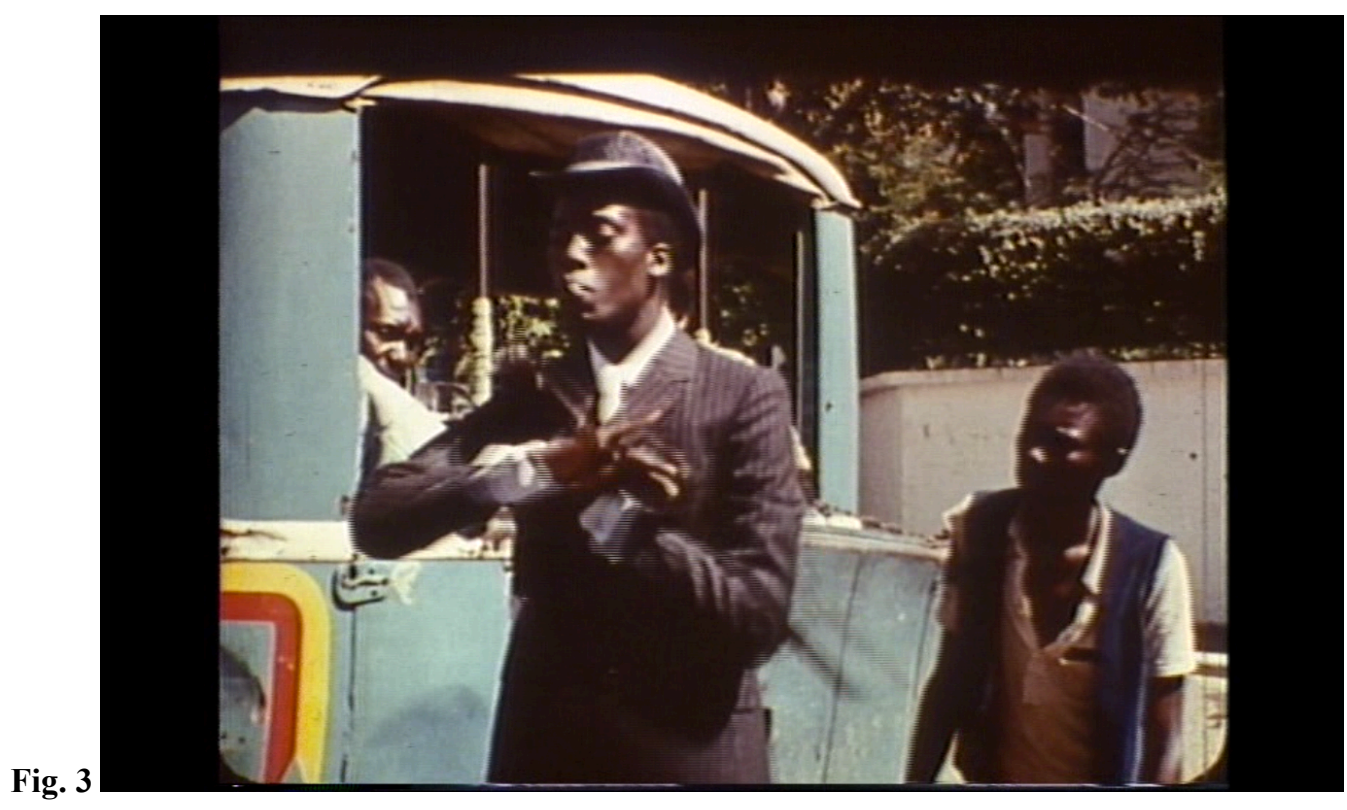

Given that Badou Boy is a silent comedy, it is not surprising that Chaplin-a likeness of, that is-makes an appearance. In one of the sequences where the main character and the passengers he has recruited are riding the car rapide through the city, the vehicle pulls in front of an administrative building, the Offices des postes. A man wearing a pinstripe suit and bowler hat, carrying a cane and briefcase, walks flamboyantly down the steps. He approaches the car rapide, but stands facing away from Badou Boy and the other passengers while he meticulously removes the plastic tip from his cigarette (figure 3). Finally, the man turns around and, with great pomp he stretches his cane out in front of him and steps onto the vehicle. The music during this scene is a symphony playing a classical piece; the musical motif, combined with the man's showiness, offers a humorous critique of the bourgeois members of postcolonial society. The unmistakable parallel to Chaplin in the man's style of dress, accessories-including the cigarette, exaggerated

83 The Chaplin Mutual Comedies (1916-1917; Chatsworth, CA: Image Entertainment, 2006), DVD. 
gestures, and overall comic presence is at home in the film's silent comedy mode. To further exemplify his affinity with Chaplin, Mambéty himself plays the part of his double.

Badou Boy also makes reference to Charlie Chaplin's quintessential adversary, in addition to a likeness of the little man. According to Colin Chambers, Chaplin "delights in using cartoon devices such as huge bullies" as a means to emphasize his tiny stature, but it serves a comic means, as well. ${ }^{84}$ The bully of epic proportions in Badou Boy is Al Demba, the policeman. This corpulent character is constantly in pursuit of the young hooligan. Following the opening credit sequence, the next shot features Al Demba as he runs towards the camera; the extreme slow-motion effect makes it appear as if he is making no progress at all, a true quality of his police investigation over the course of the film. He successfully captures Badou Boy in his daydreams, but never in reality, as Sada Niang observes: "much of the police work in this film occurs in the imagination of this character." ${ }^{85}$ In addition to his physical struggles, his speech is a maladroit mixture of Wolof, French, and English. We only hear this idiom in voice-over dialogue between Al Demba and the man's superior, who is well versed in standard French. ${ }^{86}$ This character's unflattering attributes serve as a strident critique of the police force, and more generally of authority figures in the newly postcolonial era. To accentuate the policeman's ineffective qualities, his mode of transport is a tattered bicycle, which he lugs around the city throughout his chase. It weighs him down far more than it renders him mobile. In one instance, he is walking while pushing his bike as he approaches a large puddle that Badou Boy deftly jumped over moments before. Rather than ride the bike through the insignificant obstacle, he painstakingly drags it around the puddle. This laughable, absurd behavior evokes Chaplin's conduct, such as the moment in The Pawnshop (1916) when his character, a shop employee,

\footnotetext{
${ }^{84}$ Colin Chambers, Here We Stand: Politics, Performers and Performance (London: Nick Hern Books, 2006), 102.

${ }^{85}$ Sada Niang, Djibril Diop Mambéty: Un cinéaste à contre-courant (Paris: L’Harmattan, 2002), 58.

${ }^{86}$ Both roles are recorded by Mambéty.
} 
meticulously deconstructs a clock that a man wishes to trade in; instead of giving him money, the Tramp gives him the pile of pieces and a thump on the head with a hammer. ${ }^{87}$

Through his allusions to Chaplin in Badou Boy, Mambéty criticizes authority figures and, by extension, the functioning of postcolonial Senegalese society. The examples are comical, which relates to Alexie Tcheuyap's argument that certain African filmmakers have used comic strategies subversively, although he does not include Mambéty’s films in his discussion. ${ }^{88}$ Tcheuyap anchors his reading in Jean-Paul Simon's theory, from Le filmique et le comique, that "comedy can only be defined as subversive [...] when comedy appears in a film - usually via a gag - it erupts and thereby disrupts orders, institutions and codes." ${ }^{89}$ An example from Mambéty’s film Le Franc (1994) demonstrates how he incorporates elements from Chaplin's work in order to subvert the larger socio-economic order. ${ }^{90}$ In Le Franc, the main character, Marigo, a poor man, buys a lottery ticket and glues it to the inside of the door to his shack, underneath a poster of Yaadikoone Ndiaye. The anticolonial activist, characterized by Marigo in the film as "Notre Robin des Bois à nous, le protecteur des enfants et des plus faibles," appealed to Mambéty for his "habit of bursting open the doors of local cinemas after the lights had gone down so that the local children could get into the movie theatre for free." ${ }^{91}$ Upon learning that he holds the winning numbers, Marigo unhinges the door and carries it above his head all the way to

\footnotetext{
87 The Chaplin Mutual Comedies (1916-1917; Chatsworth, CA: Image Entertainment, 2006), DVD.

88 Tcheuyap, Postnationalist African Cinemas, 48. Jean-Paul Simon, Le Filmique et le comique (Paris: Albatros, 1979).

${ }^{89}$ Tcheuyap, Postnationalist African Cinemas, 48.

90 Le Franc, directed by Djibril Diop Mambéty (1994; Paris: La Médiathèque des Trois Mondes (M3M), 2002), DVD. Along with La Petite Vendeuse de Soleil (1999), Le Franc is part of a trilogy that was set to celebrate the lives of ordinary people, called Histoires de petites gens (Tales of Ordinary People), but due to his untimely death he was not able to complete it.

91 Murphy and Williams, Postcolonial African Cinema, 101. Marigo characterizes Ndiaye as “our own Robin Hood, protector of children and the weak." (My translation)
} 
the administrative office to collect his money only to learn that he must un-stick his ticket, a challenge he resolves by carrying the door into the sea.

Marigo's quest transporting the door is characterized by a series of slips, falls, and struggles; this physical comedy evokes Chaplin's own pratfalls. The reference to Chaplin is also evident in a key aspect of Marigo's dress: he wears a bowler hat. One moment in particular recalls a gag typical of Chaplin, for instance from The Pawnshop. Marigo, hauling the door above his head, enters a narrow alleyway. When he has gone a few steps, a man pushing a loaded cart enters from one end, forcing him to turn around, but a man carrying a heavy sack enters from the opposite end a moment later, trapping him in the middle of the alley. He escapes and at the end of the film celebrates that he is still in possession of the lottery ticket, however, it is of little value due to the devaluation of the Franc CFA by fifty percent, a fact that is alluded to at the start of the film. Thus, Marigo's efforts, in the style of Chaplin's physical comedy, denounce the socio-economic conditions of life in Dakar in the 1990s.

An aspect in Mambéty's films that remains to be explored in relation to Chaplin's work is the notion of a basic, shared humanity. At the heart of Mambéty's project as a filmmaker is a desire to transcend limits of socioeconomic class, gender, language and nationality, not necessarily in the articulation of a specific postcolonial project, but more generally to evoke a common sense of humanity. This is an approach that he inherits, at least in part, from Chaplin and his own particular brand of humanism. In their assessment of Mambéty's work with respect to the modern, the postmodern and the postcolonial, Murphy and Williams posit that we see in Mambéty’s films “the cinematic exploration of what it means to be human in postcolonial Africa." 92 Their discussion draws on Kwame Anthony Appiah's essay "The Postcolonial and the Postmodern," where he writes about the postcolonial African artists who reject 'grand narratives'

92 Murphy and Williams, Postcolonial African Cinema, 108. 
that support the existence of an essentialist African identity, such as narratives in favor of the nation-building project. ${ }^{93}$ Rather, Appiah argues, certain postcolonial African artists "seek instead to promote a more general sense of African solidarity and humanity," write Murphy and Williams. ${ }^{94}$ They apply Appiah's philosophy to Mambéty’s films, and propose that his films "act as a useful and necessary step in exploring a common sense of humanity and elaborating a new humanism for the twenty-first century." 95 His characters, such as Marigo, inspire sympathy but also arouse laughter, traits that resonate with Chaplin's characters, who attained a sort of world citizenship. Cinematically, Mambéty’s espousal of various styles and movements stakes a claim to a world cinema heritage.

Mambéty has many admirers among francophone sub-Saharan African filmmakers of later generations, due in part to his innovative use of diverse filmmaking styles. His narrative and aesthetic strategies in Badou Boy, which include intertextual references to Chaplin and silent-era filmmaking, are themselves intertextual references in José Zéka Laplaine's short film Le Clandestin. ${ }^{96}$ Indeed, the young man in trouble, the policeman, and the chase are narrative elements that also characterize Le Clandestin, which goes further than any other film by a francophone sub-Saharan African director in its stylistic allusion to the silent era. Laplaine's primary narrative and aesthetic strategy of executing his film in the silent mode is a means of expressing a desire for a common or shared humanity.

José Zéka Laplaine (often referred to as either José or Zéka Laplaine) is from the Democratic Republic of the Congo. He is the child of a Congolese mother and a Portuguese

\footnotetext{
93 Kwame Anthony Appiah, In My Father's House: Africa in the Philosophy of Culture (Oxford: Oxford University Press, 1992), pages 137-57.

94 Murphy and Williams, Postcolonial African Cinema, 108.

95 Ibid., 109.

96 Le Clandestin, directed by José Zéka Laplaine. Cinémas d'Afrique (France: Centre National de Documentation Pédagogique, 2001), DVD.
} 
father, a heritage he evokes in the setting of Le Clandestin. A Franco-Portuguese production, Le

Clandestin was filmed over the span of a few days while Laplaine's first feature, Macadam

Tribu, was in post-production. ${ }^{97}$ Since 1996 , he has made four feature films, which have received very little scholarly attention; only one article is devoted to Le Clandestin. ${ }^{98}$ In addition to directing, Laplaine is also an actor and generally casts himself in his own films. ${ }^{99}$

\section{Le Clandestin (The Stowaway, 1996): New 'Takes' on a Familiar Theme}

If one were unaware of the year in which Le Clandestin was made, one would assume that it dates to the early twentieth-century, before the talkies. Shot in black and white, the film uses intertitles, sound effects, and an integrated musical score; all of these elements are indicators of the silent era. In addition to these technical aspects, the film's rhythm, plot elements, such as the chase narrative, and the use of pantomime and slapstick humor, are common devices from the silent mode. The film tells the story of a young man who attempts to emigrate from his African country to Portugal, but fails. It opens with a series of shots of Lisbon harbor and then focuses on the title character's arrival at the cargo dock. From the moment the young man steps out of the container in which he arrived, a policeman is after him. Beginning at the dock, the chase proceeds throughout the city and lasts the better part of a day. Eventually the men tire, exchange brief words, which constitute the sole dialogue in the film, and become

97 Olivier Barlet, “À Propos de Le Clandestin et Macadam Tribu. Entretien d'Olivier Barlet avec José Laplaine, Fespaco 97," Africultures, August 29, 2002, http://www.africultures.com/php/index.php?nav=article \&no=2439\& texte_recherche $=$ jose $\% 20$ laplaine.

${ }^{98}$ Marie-Hélène Gutberlet, "Towards an Aesthetic of the Migrant Self - The Film Le Clandestin by José Zéka Laplaine," in Transcultural Modernities: Narrating Africa in Europe. Matatu - Journal for African Culture and Society 36, ed. Elisabeth Bekers, Sissy Helff, and Daniela Merolla (Amsterdam: Editions Rodopi, 2009): $287-95$. ${ }^{99}$ He acted in a Brazilian production, Terra Estrangeira (1996) directed by Walter Salles and Daniela Thomas, played a "cowboy" alongside Danny Glover in Death in Timbuktu, the short western film in Abderrahmane Sissako's Bamako (2006), and played the role of a character named Zéka in Mousse Sène Absa's Téranga Blues (2007). 
friendly. The film ends with the two men walking toward the harbor as the last intertitles informs us that the stowaway has returned to his home country.

The subject of the film is not original. Indeed, "narrating migration to Europe can be regarded as a topos in African filmmaking," observes Marie-Hélène Gutberlet. ${ }^{100}$ However, comedies are rare regarding this topic, she notes, a claim that is supported by the fact that she lists only one example of a film on migration with a comic twist. ${ }^{101}$ The comic elements are one component of the film's narrative and aesthetic strategy of using the silent mode; this is where the film's originality lies. Among the earliest forms of filmmaking, the silent mode inevitably evokes the discourse surrounding the emergence of the cinema, such as the celebration of film as a 'universal language. ${ }^{, 102}$ In its stylistic reference to the silent mode, Le Clandestin invokes the early days of cinema, and through its mise-en-scène of African subjects, asserts or lays claim to its own part in film history. While Gutberlet raises the idea of a universal film language, she leaves room for it to be further explored, including the film's key aesthetic strategies that are integral to the notion. The universal film language reflects the story being told-that of an immigrant and the challenges he faces, which is one that transcends space and time and applies to many periods of history, nationalities, and so forth. Le Clandestin thus renews the common theme in African filmmaking, immigration from Africa to Europe, by transposing it into a modern context.

As commonly done in silent films, Le Clandestin uses intertitles to inform spectators of the title character's voyage and to provide access to his inner sentiments. They are written in the form of a letter addressed to the main character's cousin who resides somewhere in Europe; the casual typeface evokes handwriting. Aside for the first and last intertitles that bookend the

\footnotetext{
100 Gutberlet, "Towards an Aesthetic of the Migrant Self," 288.

101 Back Home Again, directed by Kwame Johnson and Coffe Zokko Narty.

102 Gutberlet, "Towards an Aesthetic of the Migrant Self," 294.
} 
narrative, the appearance of the intertitles is like that of many silent films, with a decorative frame outlining the text (figure 4). For the duration of each intertitle, a clarinet riff plays in the soundtrack, giving this moment its own space in the film both visually and sonorously. The first insert, which scrolls on the screen mere seconds into the film, unveils the outcome of the young man's journey: “Cher cousin, Tu dois te demander ce que je fabrique. Tu sais, j’ai essayé de te rejoindre en Europe en me cachant dans un container comme prévu. Quelle aventure..."103 The use of the past tense reveals that the phase following his overseas passage was unsuccessful. As in many silent films, such as L'Atlantide (1921) directed by Jacques Feyder, the intertitles function primarily as descriptive narrative material, written after the fact. ${ }^{104}$

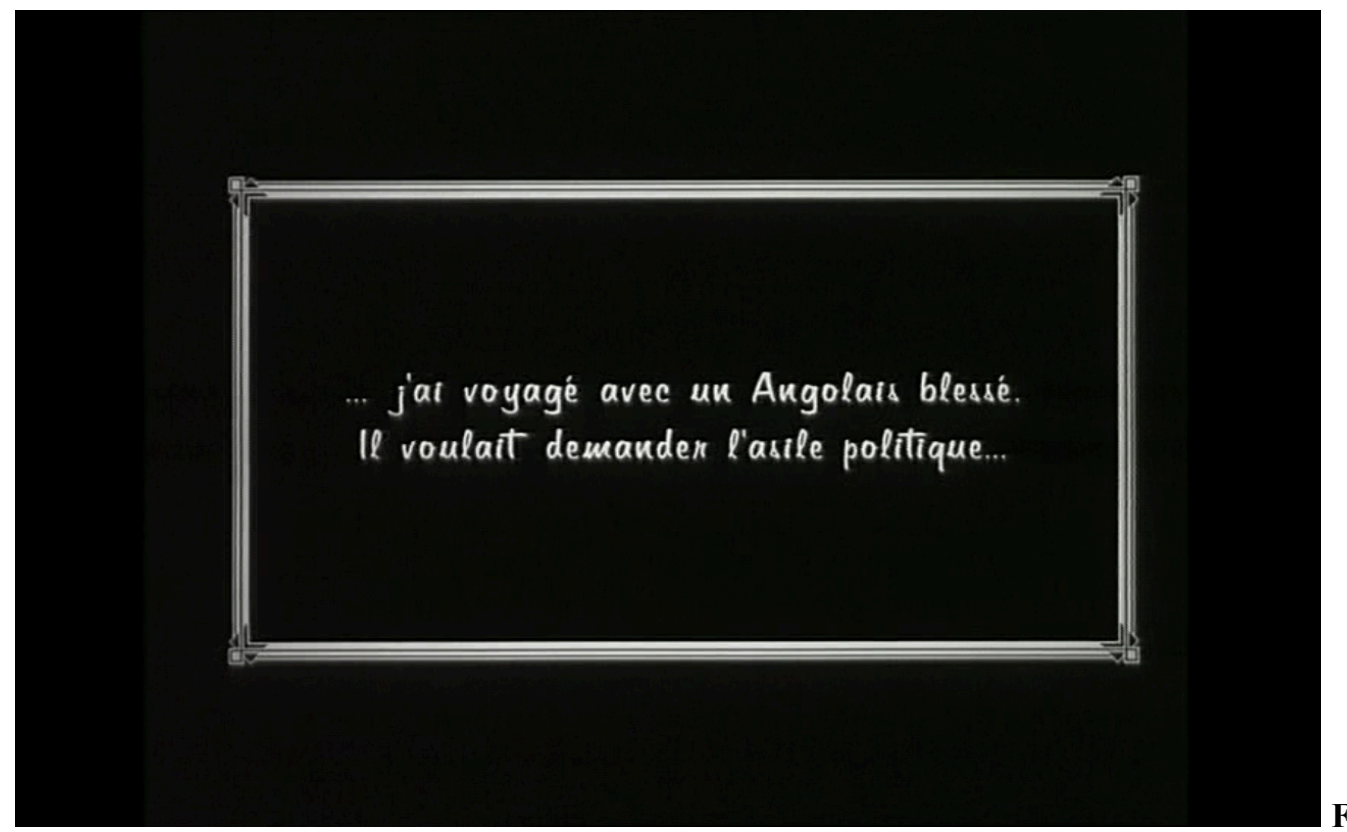

Fig. 4

\footnotetext{
103 "Dear cousin, You must be wondering what I am up to. Well, I tried to join you in Europe by hiding out in a container as planned. What an adventure..." All translations from Le Clandestin are mine.

${ }^{104}$ L'Atlantide, directed by Jacques Feyder (1921; Paris: MK2 Éditions, Lobster Films, 2004), DVD.
} 


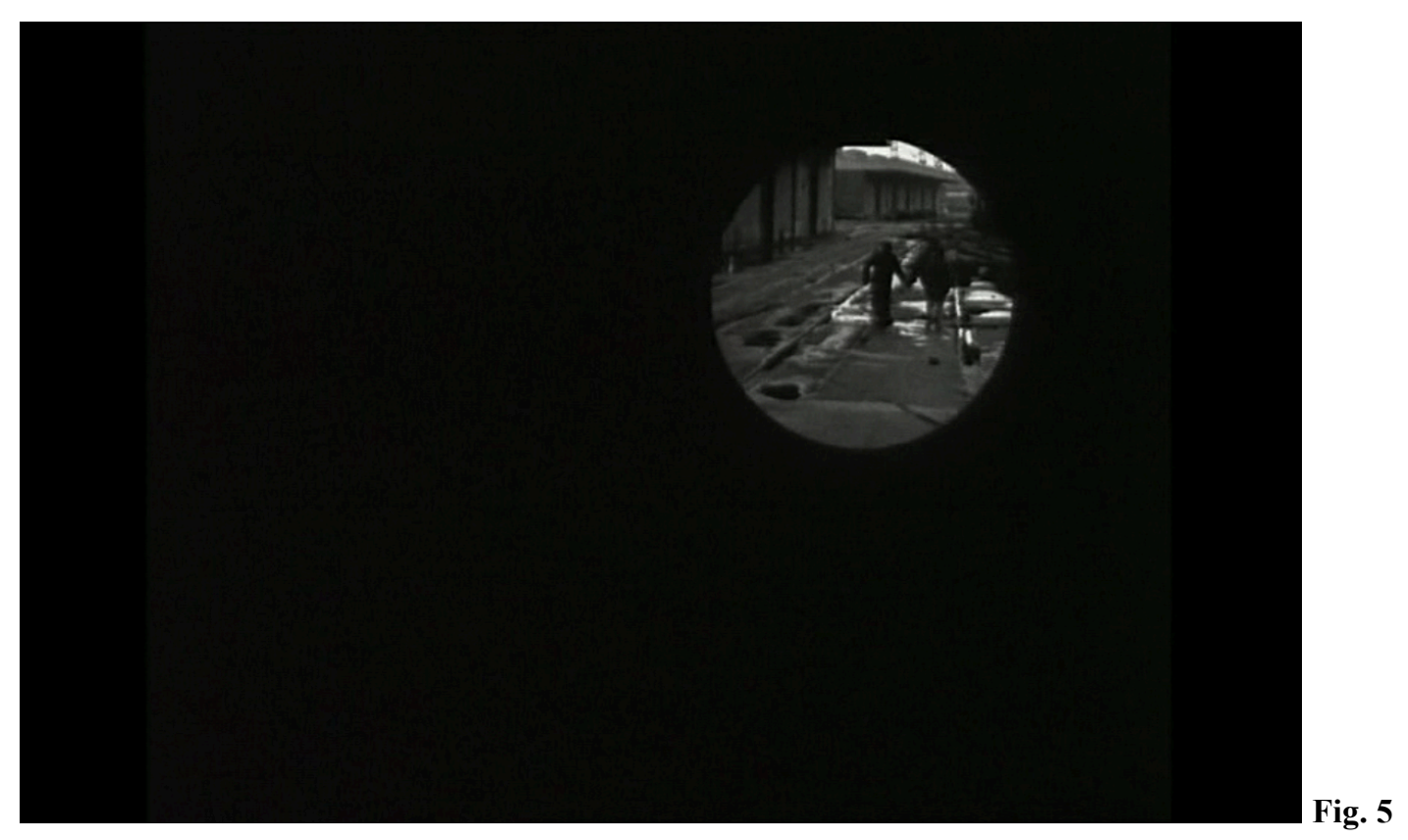

In addition to the use of intertitles, another prominent technique from silent-era

filmmaking in Le Clandestin is the iris-out. Like other early cinematic techniques, the iris-in/out involves exploring the possibilities of the cinematic medium, and making use of them if not for any reason other than advertising its unique attributes. In this vein, Miriam Hansen explains, "the basic conception of early filmmaking is one of display, of demonstration, of showmanship."105 Chaplin makes frequent use of the iris-in/out, the former signaling the beginning of a new chapter within the film, and the latter marking the end of a scene or chapter. In the sequence that depicts the stowaway's arrival in Lisbon harbor, the zooms are reminiscent of the iris-out. For example, one shot features the protagonist inside the cargo container in which he arrived. A beam of light enters through a small hole in the side of the container revealing the perspiration that covers his face. The camera zooms in on his face and then follows the beam of light through the hole. This technique marks a transition from the stowaway's arrival in the container to his first exploits in Portugal's capital city. An iris-out also signifies the end of the stowaway's brief adventure at the end of the film. The final shot shows the stowaway and the policeman walking 105 Hansen, Babel and Babylon, 33-34. 
side by side. The camera zooms in on the two characters in iris-out (figure 5). It punctuates the end of his journey while also highlighting the amicable relations between the two characters. This technique is immediately followed by music dating to the silent era, an upbeat, jazzy piano melody.

Le Clandestin also evokes early cinema through the sound editing. Sound mixing clearly diverges from silent era film logic, as synchronous sound had not yet been invented. However, Laplaine's playful approach to it enhances the narrative and emotional content, a strategy aligned with the use of sound during the silent era. In the opening sequence at the harbor, various sounds are inserted, such as the squealing of car's brakes, a ticking stopwatch, and a shrill alarm ringing. While they are incongruous with the images onscreen, the sounds amplify the action.

Additionally, Laplaine accentuates the menacing attributes of the city and its people in the use of non-diegetic animal sounds. For instance, dogs bark, snarl, and growl, each evoking the degree of threat posed by certain characters. The policeman chases after the young man while waving around a club, but he is never truly vicious, thus, the sound associated with him is a simple bark. On the other hand, the angry driver who nearly kills the stowaway is paired with a menacing, bloodthirsty growl.

The film alternates between slow and fast-paced moments, according to whether or not the stowaway is being chased by the policeman. The narrative and aesthetic strategy of the early cinema tended to emphasize display rather than storytelling. A “"cinema of attractions,' it arouses a curiosity that is satisfied by surprise rather than narrative suspense," writes Tom Gunning. ${ }^{106}$ He explains further, "attractions have one basic temporality, that of the alternation of

\footnotetext{
106 Tom Gunning, “"Now You See It, Now You Don't': The Temporality of the Cinema of Attractions,” in Silent Film, ed. Richard Abel (New Brunswick, NJ: Rutgers University Press, 1996), 75. Gunning is careful to point out that an emphasis on display rather than storytelling should not be taken as a monolithic definition of early cinema, nor should narrativity be identified solely with classical cinema.
} 
presence/absence that is embodied in the act of display." 107 This notion of attractions characterizes the rise and fall of narrative action of Le Clandestin, as the (re)appearance and disappearance of the policeman determines the narrative action and rhythm of the film. The incorporation of this device draws a clear parallel not only with the silent era but also with Chaplin's films. For example, in The Immigrant, the Tramp has a series of misadventures as he immigrates to America. ${ }^{108}$ Each scene relies on a back-and-forth between moments of good fortune and ease, and moments of mischief and trouble. The notions of rises and falls is quite literally depicted in one moment where the ship is rocking back and forth to an alarming degree; the Tramp and the other passengers roll from one side of the deck to the other. While there is no such equivalent in Le Clandestin, the stowaway's journey is highly similar to the Tramp's in terms of the film's basic temporality. The rises and falls advance the narrative as opposed to building suspense, gradual character development, and dialogue.

A major theme in silent film and in Chaplin's works is attention to the underprivileged and their efforts to get by in a harsh world. Similarly, the stowaway is consistently met with hostility, yet he also amuses spectators in his mannerisms. Like Chaplin's Tramp, he is a clown. For instance, during one stretch of wandering in the city while he is temporarily free of the policeman, the stowaway attempts to ease his hunger and thirst. He discovers a packet of cigarettes inside the pocket of a coat he grabbed off of a man who tried to rob him. A close-up shot shows him struggling to finish smoking one of many cigarettes; he looks ill. He drops the cigarette butt on the ground into an accumulating pile. While we feel sympathy for the stowaway, this moment inspires laughter at the fact that it was not necessary to smoke the entire

\footnotetext{
107 Gunning, "'Now You See It, Now You Don't," 76.

108 The Chaplin Mutual Comedies.
} 
supply of cigarettes. The cigarettes also evoke Chaplin, who is almost never without, as does the theme of hunger, in which Chaplin found a rich source of jokes.

If the stowaway is the hero of slapstick comedy, his adversary is also a recognizable character type from Chaplin's films, the bully. Like the policemen in Chaplin's The Immigrant and Mambéty's Badou Boy, the character in Le Clandestin is more a caricature than an actual authority figure. His stout figure, paired with his baton and whistle, make him appear cartoonish. The first image of him in the film is a side angle shot of his mid-section, as he slaps his baton into his palm. This is not the only moment where the film draws our attention to the policeman's physical attributes. In the fourth intertitle, the stowaway describes him as bien nourri and notes that, as a result, he cannot run very fast. The policeman's comic dimension takes on a selfreflexive, and self-deprecating, tone considering that Laplaine himself plays the part.

While the policeman's primary motive of capturing the stowaway leads us to believe that he is the 'bad guy,' the true villain is a bigoted individual. He is portrayed as a caricature in his sputtering, mumbling, and grimaces, although his racist remark in an intertitle - "NEGRO!" casts a more serious tone than has been the case up to this point. His presence in the film causes the stowaway and the policeman to become allies, facilitating a dialogue between the two men. In the sole moment of verbal exchange in the film, the policeman states, "Brother, no good," to which the stowaway replies, "Africa, no future." While the spoken word is surprising in an otherwise silent film, perhaps even more so is the use of English. One might assume that the spoken language would be French, like the inserts, or Portuguese, to reflect the film's setting. The choice of English is part of the universal aspect of the film's project.

Laplaine's film is an example of how Chaplin and silent film have permeated African filmmaking, a heritage that can also be traced to Mambéty. Even though the subject of Le 
Clandestin is not original to begin with, it incorporates numerous stylistic devices as a means of renewing the familiar theme of immigration. In Laplaine's incorporation of a highly recognizable cinematic style, his project assumes wider significance. In sociopolitical terms, Laplaine’s project is a nostalgic one, in the sense that through the evocation of the silent era and its simple, visual language, it demonstrates a yearning for the actual situation for immigrants to be less complicated. This evokes the notion of silent film as a utopian genre in light of the absence of dialogue, the basic technical aspects, the profoundly human emotional aspect, and the timeless quality, as sketched out by Dani Kouyaté. It also calls to mind the notion of humanism from Mambéty's films. In addition to asserting a place in world film history, Le Clandestin's use of the silent mode suggests that allusions to the silent era in African filmmaking may be the elaboration of a new humanism.

\section{'New Wave' Directors' Affinities with Chaplin}

In the same year that Le Clandestin came out, two films by filmmakers of Laplaine's generation also evoke Chaplin and his era: Le Damier - Papa National Oyé! (1996) by Balufu Bakupa-Kanyinda, and Aristotle's Plot (1996) by Jean-Pierre Bekolo. This coincidence affirms that Chaplin and the silent mode remain central cinematic references for filmmakers of the "new wave," Manthia Diawara's category for artists who were born around the time of independence. ${ }^{109}$ Further, it draws our attention to the wider trend among directors of this generation of engaging with cinematic styles and movements from other eras and regions of the world. In the following examples from Bakupa-Kanyinda and Bekolo, the allusions to Chaplin differ greatly from the example from Le Clandestin. They deploy thematic and stylistic strategies that evoke Chaplin as a means to subvert certain types of authoritative discourse.

\footnotetext{
109 Diawara, African Film.
} 
Bakupa-Kanyinda engages with Chaplin's works in his medium-length film Le DamierPapa National Oyé! (1996). ${ }^{110}$ As a political satire that denounces a contemporary authoritarian ruler, it evokes The Great Dictator (1940) by Chaplin. ${ }^{111}$ In this film, Chaplin takes full advantage of the Tramp's physical likeness to the Nazi leader and parodies Hitler's rise to power while the situation was still unfolding. In a similar vein, Le Damier criticizes Mobutu Sese Seko, the former Zairian president, and his autocracy. Set in a fictitious country called Payssien, the film depicts the president as an insomniac who orders his guards to seek out the country's most competitive players to play checkers (draughts) against him each night. ${ }^{112}$ Regardless of the outcome, the competitors tend to mysteriously disappear afterward. The game paradigm reflects the conditions of the country's impoverished and powerless population, who are like pawns in a rigid system, a parody of the situation at the time. Bakupa-Kanyinda clearly evokes Mobutu through the president's style of dress (notably his animal-print hat and sunglasses), and through explicit and implicit references to 'la revolution authentique,' such as the use of the term 'citoyen.' At the same time as he provides strident criticism, Bakupa-Kanyinda infuses the film with many humorous and absurd elements, and achieves a light-hearted tone. For instance, the inactivity and dim intelligence of the palace guards, who congregate around walkie-talkies to survey the president's activities, provide amusement throughout the film. They fear for the life of the president's opponent who boldly demands alcohol and marijuana in order to access his skills; as a result, his behavior toward the president quickly goes from deferential to insulting. The use of these and other comic elements allows Bakupa-Kanyinda to approach subversive issues, a

\footnotetext{
${ }^{110}$ Le Damier - Papa National Oyé! (The Draughtsmen Clash), directed by Balufu Bakupa-Kanyinda (1996; New York, NY: ArtMattan Productions, 2000), DVD.

111 The Great Dictator, directed by Charlie Chaplin (1940; Chatsworth, CA: Image Entertainment, 2000), DVD.

112 The name Payssien (pays sien) loosely translates to "His country."
} 
strategy that Chaplin deploys in The Great Dictator. Interestingly, both Chaplin and BakupaKanyinda were forced into exile due to their political activism.

The example from Bekolo stages issues related to film production. His radical film essay Aristotle's Plot was initially a commissioned entry for the BFI's centenary of cinema celebration. ${ }^{113}$ It is a reflection on the relation between African filmmakers and African film audiences, which Bekolo explores through the conflict between the tsotsis, who are obsessed with Hollywood action films, and a serious African filmmaker, who has just returned home from Europe and who values 'traditional' and 'authentic' African narratives. Bekolo provides voiceover narration in which he comments on the narrative as it unfolds as well as the circumstances of the film's production. His self-reflexive stance and ceaseless irony and humor are constant reminders that the film is a commissioned work. Indeed, as Akin Adesokan writes, the film's commissioned status "is in copious evidence throughout the narrative." 114 In one sequence in particular, Bekolo illustrates issues of production that pertain specifically to the film we are watching, but also apply more generally to African filmmaking. The example borrows stylistically from early silent comedies.

Bekolo is known for incorporating elements from many filmmaking styles and movements. Additionally, the staging of conceptual issues is recurrent in his work. Both of these strategies are at play in the example from Aristotle's Plot. Essomba Tourneur (referred to as E.T., which evokes Steven Spielberg's eponymous film, a First Cinema reference), the main character, is a filmmaker who has recently returned from Europe where he did film training. The sequence, which is comprised of only two shots, primarily features a long shot with a line of parked cars in the background. E.T. enters the frame from the right, while the camera remains

113 Aristotle's Plot, directed by Jean-Pierre Bekolo (1996; Paris: JBA Production, 2004), DVD.

114 Akin Adesokan, Postcolonial Artists and Global Aesthetics (Bloomington: Indiana University Press, 2011 ), 111. 
stationary, an unusual technique compared to the rest of the film, and one that contributes to the silent film effect. The vehicle owners, all white men, stand leaning against their classic Peugeots from the 1960s and early 70s, a detail that ties the characters to France. An upbeat piano riff plays for the duration of the sequence. The tune is out of character with the rest of the soundtrack and recalls the player-piano style of musical accompaniment from the silent era. As E.T. enters the frame and crosses the parking lot, the men eagerly attempt to grab his attention by waving to entice him to hand over his film reels and climb into their vehicle. They then hassle him physically, and fight with one another for possession of the shopping cart. E.T. finally regains control and exits the frame as the music comes to a close.

Due to the silent film style, the overall sequence remains humorous and light-hearted. It illustrates Western patronage with respect to African film production. As Westerners/outsiders, the men-touts, to adopt the term Kenneth Harrow uses-represent foreign commissioning editors who attempt to exert control on aspects of E.T.'s films, due to their sponsorship. ${ }^{115}$ Their physical conflict enacts the situation that faces francophone African filmmakers who receive outside funding from French or Western sources. More specifically, it pertains to the production of Aristotle's Plot, which ultimately did not receive sponsorship from the BFI. Executing the sequence in the style of silent films allows Bekolo to foreground the issues germane to the film we are watching as well as the larger issues facing African filmmakers.

In the examples from Le Damier by Bakupa-Kanyinda and Aristotle's Plot by Bekolo, we see how borrowing thematically and stylistically from Chaplin's work and silent-era filmmaking allows the filmmakers to assert a critical perspective. My next chapter is devoted to these two

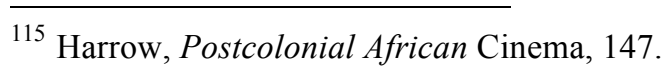


directors and analyzes how they deploy self-reflexive narrative and aesthetic strategies to subvert forms of authoritative discourse, which expands upon my argument in this section.

The directors examined in this chapter saw in Chaplin an ally. He was a representative of the underprivileged, critical of authority, and his films exemplified the wrapping of political messages in a comic spin. His films appealed to the masses and achieved recognition on a global scale. By tracing evidence of Chaplin's appeal among populations in Africa from the midtwentieth century through present day, this study further emphasizes the vast scale of the film icon's indelible mark. Further studies similar to this one would certainly reveal that his influence extends into other parts of the world that have not previously been explored.

The reception of Chaplin's films in parts of French and British Africa during the colonial period attests to the construction of a collective cinematic memory. Over the course of the 1940s and 1950s, when audiences were exposed to mobile film programs, the image of the Tramp became embedded in the popular imagination. By visually quoting him in their films, like the poster of the Tramp in Sembène's Xala or the film poster of The Kid in Haroun's Abouna, directors cite their affinity for Chaplin, which signals a commonality with spectators; they, too, consumed and loved mainstream movies. Francophone sub-Saharan African directors, especially contemporary ones, are often accused of creating intellectual, art house films for primarily European or Western audiences. Yet Chaplin was a popular figure who made commercial entertainment films. Thus, the incorporation of aspects of Chaplin's work into their filmmaking practices is a key critical avenue for reconciling this discussion. If we contextualize this discussion within the larger division of filmmaking practices, francophone sub-Saharan African cinema is in fact aligned with First Cinema and not strictly Third or even Second Cinema practices. 
In addition to allowing us to re-evaluate African cinema's relation to international cinematic traditions, allusions to Chaplin may also help us to better understand and articulate the postcolonial project. Exploring Sembène's personal history with Chaplin, we view him as a cinephile and consumer of popular movies, a portrait that is rarely drawn of the militant artist. Chaplin's artistic legacy may have led Mambéty to elaborate a new form of humanism. If explored further, this idea may help us to better appreciate his legacy among filmmakers of the contemporary generation.

The use of silent mode devices in contemporary filmmaking invokes a recent French production, The Artist (2011), directed by Michel Hazanavicius. It is uncertain whether Hazanavicius has viewed José Zéka Laplaine’s short film Le Clandestin, but he cites Chaplin's City Lights as his main source of inspiration when writing the film's script. ${ }^{116}$ As a mainstream production and internationally renowned film, The Artist indicates a larger tendency of allusions to Chaplin and the silent era in contemporary filmmaking. More broadly, it reveals ongoing, widespread efforts to revive the silent form, and to pay homage to the early, basic methods of filmmaking.

\footnotetext{
${ }^{116}$ Eric Kohn, 'Six silent films that inspired 'The Artist.' Notes by Michel Hazanavicius.” Indiewire, November 21, 2011, http://www.indiewire.com/article/the-artist-director-michel-hazanavicius-on-the-films-that-inspired-him.
} 


\section{Chapter Two}

\section{Screening Alternatives: A New Political Film Language Les Saignantes and Juju Factory}

Jean-Pierre Bekolo's third feature film Les Saignantes (The Bloodettes), from 2005, opens with a loud clap of thunder accompanied by a streak of lightning. ${ }^{1}$ It is startling and somewhat incongruous in the still, pitch-black sky above the city lights of Yaoundé, Cameroon's capital city. While the thunder does not mark the presence of a storm, it announces Bekolo's explosive aesthetics and signifies a rupture that effectively encapsulates the manner in which he "stormed the annals of African filmmaking," in the words of Akin Adesokan. ${ }^{2}$ Since his first feature, Quartier Mozart (1992), he has been at the forefront of a new generation that has been working to broaden the narrative and aesthetic possibilities of African cinema. ${ }^{3}$ Originally trained as a film editor, Bekolo consistently challenges "received social and cinematic norms," state David Murphy and Patrick Williams, through radical experimentation at the level of form, narrative, and subject matter. ${ }^{4}$ His second feature, Aristotle's Plot (1996), reflects on the nature of filmmaking and film consumption in Africa, while actively questioning the logic of mimesis. ${ }^{5}$ Since Les Saignantes, Bekolo has released Le Président (2013), a film that has screened in many countries world-wide with the exception of Cameroon where it is banned, and an epic-length portrait of the Congolese intellectual Valentin-Yves Mudimbe, Les Mots et les Choses de

\footnotetext{
1 Les Saignantes, directed by Jean-Pierre Bekolo (Yaoundé: Cinénomada, 2005), DVD.

2 Akin Adesokan, Postcolonial Artists and Global Aesthetics (Bloomington: Indiana University Press, 2011$), 1$.

${ }^{3}$ Quartier Mozart, directed by Jean-Pierre Bekolo (San Francisco, CA: California Newsreel, 1992), VHS.

4 David Murphy and Patrick Williams, Postcolonial African Cinema: Ten Directors (Manchester: Manchester University Press, 2007), 194.

5 Aristotle's Plot, directed by Jean-Pierre Bekolo (1996; Paris: JBA Production, 2004), DVD.
} 
Mudimbe (2014). ${ }^{6}$ Due to his bold and unconventional approach, critics often classify him as cinematic heir to maverick Senegalese director Djibril Diop Mambéty, in homage to whom Bekolo made La grammaire de grand-mère (1996). ${ }^{7}$ Like Mambéty, Bekolo aims to make a contribution to the cinematic form itself.

Balufu Bakupa-Kanyinda, a director from the Democratic Republic of the Congo, similarly seeks to undercut preconceived notions of what African cinema entails. Juju Factory (2006), his first and only feature-length film, deploys an experimental approach to form and narrative, and seeks to deconstruct problematic notions of African authenticity. ${ }^{8}$ BakupaKanyinda's belief that "to produce a film in Africa constitutes an act of resistance" also informs his two political satires, Le Damier - Papa National Oyé! (1997) and Article 15 bis (1999), which playfully explore a repressive state structure. ${ }^{9}$ His formally experimental documentary, Afro@digital (2002), which he describes as a “"manifesto' of the African digital mind,” offers a reflection on the impact of various technologies across different domains in Africa. ${ }^{10}$ BakupaKanyinda made his cinematic debut with Dix mille ans de cinéma (1991), a short film that features several African directors at FESPACO in 1991, including Mambéty. ${ }^{11} \mathrm{He}$ expresses a deep admiration for the late Senegalese director in an essay devoted to his memory, and

\footnotetext{
${ }^{6}$ Le Président, directed by Jean-Pierre Bekolo (Cameroon/Germany: Weltfilm, 2013), DVD. Les Mots et les Choses de Mudimbé (Mudimbe's Order of Things), directed by Jean-Pierre Bekolo (Cameroon: Jean-Pierre Bekolo SARL, 2014), DVD.

${ }^{7}$ La Grammaire de grand-mère, directed by Jean-Pierre Bekolo. On Aristotle's Plot, dir. by Jean-Pierre Bekolo (1996; Paris: JBA Production, 2004), DVD.

${ }^{8}$ Juju Factory, directed by Balufu Bakupa-Kanyinda (Paris: Akangbe Productions, 2006), DVD.

${ }^{9}$ Balufu Bakupa-Kanyinda, "Film in Africa, Africa in Film: Challenging Stereotypes," UN Chronicle 40, no. 1 (March-May 2003), 27. Le Damier - Papa National Oyé! (The Draughtsmen Clash), directed by Balufu BakupaKanyinda (1996; New York, NY: ArtMattan Productions, 2000), DVD. Article 15 bis, directed by Balufu BakupaKanyinda (Democratic Republic of the Congo/France: Akangbe Productions/Dipanda Yo!, 1999), 35mm.

${ }^{10}$ Ibid. Afro@digital, directed by Balufu Bakupa-Kanyinda (San Francisco, CA: California Newsreel, 2002), DVD.

${ }^{11}$ Dix mille ans de cinéma, directed by Balufu Bakupa-Kanyinda (France: Scolopendra Productions, 1991), 16mm.
} 
characterizes both him and his work as “une 'œuvre' du patrimoine de la cinématographie contemporaine."12

Bakupa-Kanyinda’s Juju Factory and Bekolo’s Les Saignantes explore subversive material in highly imaginative ways. While stylistically these two films look nothing alike, they deploy a similar narrative and aesthetic strategy of enacting the process of making a film as a way to subvert or overcome certain types of authoritative discourse. In Les Saignantes, the primary narrative events of the film form an allegory of cinema; the death, dismemberment, bodily reconstitution and funeral wake of one of the male heads of state represents the different phases of film production. Performing the process of deconstruction and reconstruction in the fictional world of the film models the change needed in society. In Juju Factory, the manuscript the main character is writing over the course of the film comes to fruition at the end, creating a mise-en-abime with the film narrative. The writer-protagonist resists the restrictions imposed on him by his financial backer and successfully writes his own story, a model in the larger realm of African artistic production. Reading Juju Factory and Les Saignantes alongside one another brings out the formally inventive ways two directors seek to counter the dominant discourses of their societies and of filmmaking. These films cast "the imagination in critical and reflexive relationships with material realities," as Jude Akudinobi has written in other contexts. ${ }^{13}$ This narrative and aesthetic strategy, I posit, articulates a new political film language in African cinema.

The new political film language is a twofold concept that describes critical engagement with historical or socio-political realities on the one hand, and engagement with cinema on the

\footnotetext{
12 Bakupa-Kanyinda, "Djibril Diop Mambety: tribut cinématographique à Colobane," in Afriques 50: singularités d'un cinéma pluriel, ed. Catherine Ruelle (Paris: L'Harmattan, 2005), 277.

13 Jude G. Akudinobi, "Le Président dir. by Jean-Pierre Bekolo (review)," African Studies Review 57, no. 3

(December 2014), 247.
} 
other. By engagement with cinema, I mean that the film displays an awareness of issues stemming from its context of filmmaking, and also that it is formally inventive. Films that deploy the new political film language consciously intervene in situations of dominance, and convey politically-engaged stances through self-reflexive devices. In positing this concept, I borrow from Dana Polan who theorizes the politics of self-reflexive cinema. ${ }^{14} \mathrm{He}$ describes the various attitudes a work of art adopts that appear as a conjunction of self-reflexivity and social awareness. First, the work of art displays "a distance from worldly reality, a distance inherent in art [...] a distance of codes and constructions"; second, it displays "a distance in which the work turns in on itself and speaks about its own artistic conventions and presuppositions," which is an attitude of self-reflexivity; finally, there is "a movement out of the self-enclosed world of the artwork toward a real world which the mediations of art usually leave behind." 15 The second and third phases describe the aesthetic (self-reflexive) and political (attitudes vis-à-vis the material world) dimensions of the new political film language. By political, I again borrow from Polan who broadly defines the political as that which "concerns itself with analyzing and then proposing answers to the contradictions of a particular historical situation." ${ }^{16}$ Films that demonstrate this tendency open up both a formal and political space in the viewer's consciousness.

The concept of the new political film language is both close to and distinct from the traditions of cinéma engagé (political commitment or engagement) and Third Cinema. ${ }^{17}$ In its

\footnotetext{
${ }^{14}$ Dana B. Polan, "Brecht and the Politics of Self-Reflexive Cinema," Jump Cut: A Review of Contemporary Media 17 (1974), http://www.ejumpcut.org/archive/onlinessays/JC17folder/BrechtPolan.html.

15 Ibid.

${ }^{16}$ Ibid.

${ }^{17}$ Third Cinema practices developed out of theoretical texts and manifestoes written in the late 1960s and early 1970s by filmmakers in Argentina, Brazil, and Cuba, in reaction to imperialism and other styles of filmmaking. It was mainly distinguished against a big-budget, commercial, mainstream First Cinema, and an artistic, independent, auteur Second Cinema. For more on Third Cinema, see Fernando Solanas and Octavio Getino, "Towards a Third
} 
early stages, African film was largely concerned with the post-Independence nation-building project, and the larger questions of life or death for the African community were at stake. ${ }^{18}$ Even though the "overtly political conception of film has evolved as Africa's own socio-political climates have changed, and the focus of much film work has adapted and diversified, many directors' profound commitment to the advancement of Africa has, on the whole, remained unshaken," Melissa Thackway states. ${ }^{19}$ Indeed, it is not, as Lindiwe Dovey points out, that "filmmaking in Africa and by Africans has become any less politicized than it was in the 1960s; the younger generation simply has new political concerns, and new ways of distributing those concerns. ${ }^{20}$ Contemporary filmmakers continue to focus on urgent socio-political issues from nation shaping to political corruption to fundamental issues in human rights. What is distinct from earlier, politically-engaged works-what accounts for the 'new' in the concept I propose here-is the acute awareness to the cinematic medium that each film displays. A self-reflexive mode, the new political film language deliberately rejects narrative realism, and instead adopts a self-conscious, ironic, reflexive stance toward its subject matter. "Formal experimentation is thus not incidental but integral" to these works, as Laura Marks has written in other contexts. ${ }^{21}$

The concept of a new political film language advances the new line of reflection that this dissertation proposes, self-conscious francophone sub-Saharan African cinema. In my previous

Cinema," in Rethinking Third Cinema, ed. Anthony Guneratne and Wimal Dissanayake (London: Routledge, 2003), 265-86; Julio García Espinosa, "For an Imperfect Cinema," in Film and Theory: An Anthology, ed. Robert Stam and Toby Miller (Malden: Blackwell, 2000), 287-97; Glauber Rocha, “The Aesthetics of Hunger,” in Twenty-Five Years of the New Latin American Cinema, ed. Michael Chanan (London: British Film Institute, 1983), 13-14.

${ }^{18}$ In his efforts to identify the creation and evolution of a cinéma engagé, Kenneth Harrow observes that criticism, too, felt it needed to be engagé: "it was assumed that the superficiality of entertainment or subjective feelings, fantasy and emotions should be subordinated to the greater needs identified by an engagé criticism, an engagé cinema." Kenneth Harrow, Postcolonial African Cinema: From Political Engagement to Postmodernism (Bloomington: Indiana University Press, 2007), xiv.

19 Melissa Thackway, "Exile and the 'Burden of Representation': Trends in Contemporary Sub-Saharan Francophone African Filmmaking,” Black Camera 5, no. 2 (Spring 2014), 27.

${ }^{20}$ Lindiwe Dovey, Curating Africa in the Age of Film Festivals (New York: Palgrave Macmillan, 2015$), 21$.

${ }^{21}$ Laura Marks, The Skin of the Film: Intercultural Film, Embodiment, and the Senses (Durham: Duke University Press, 2000), 1. 
chapter, I focused on the prevalence and significance of intertextual references to Charlie Chaplin and the silent mode over the course of filmmaking from the region of francophone subSaharan Africa. My discussion in this chapter contributes to the broader conception of African cinema as self-conscious by highlighting a mode that deliberately, and defiantly, calls attention to film's "artifice and operations, refusing a transparent, self-effacing language that opens quietly onto the world," in the words of Robert Stam. ${ }^{22}$

Outside their film work, Bekolo and Bakupa-Kanyinda are actively engaged in debate, dialogue and exchange in the pursuit of a conscious project of developing a new political film language. Both filmmakers belong to an organization that aims to "give a new political and aesthetic content to African and African Diaspora cinemas." ${ }^{, 23}$ Set up in 1999 by a group of African filmmakers living in France, La Guilde Africaine des Réalisateurs et Producteurs (The African Guild of Directors and Producers) "tries to make filmmakers collectively more visible and to share their experience and skills." ${ }^{24}$ Along with Bakupa-Kanyinda (the former president) and Bekolo (the former treasurer), its former and current members include Jean-Marie Teno, Mahamat-Saleh Haroun, Abderrahmane Sissako, Fanta Régina Nacro, Mama Keïta, Dani Kouyaté, Jihan el-Tahri, and Nadia El Fani. ${ }^{25}$ In their manifesto, titled Pour un nouveau cinéma africain, the Guild declares their intentions to form and transform African filmmaking so as to carve out a space in the global arena of cinemas. ${ }^{26}$ At the same time, they do not sacrifice awareness with respect to their local audiences and societies: "En tant que cinéastes, nous ne

\footnotetext{
${ }^{22}$ Robert Stam, Reflexivity in Film and Literature: From Don Quixote to Jean-Luc Godard (New York: Columbia University Press, 1992), 129.

${ }^{23}$ Manthia Diawara, African Film: New Forms of Aesthetics and Politics (Munich: Prestel, 2010), 120.

${ }^{24}$ Melissa Thackway, Africa Shoots Back: Alternative Perspectives in Sub-Saharan Francophone African Film (Bloomington: Indiana University Press, 2003), 15.

25 Diawara, African Film, 120-37.

${ }^{26}$ See Appendix 1 for a full reproduction of this text.
} 
pouvons pas fermer l'œil devant les problèmes actuels et urgents de l'Afrique."27 To the contrary, their active questioning and inventive integration of cinematic forms allows Guild directors, and Bekolo and Bakupa-Kanyinda in particular, to renew cinema's key role in the transformation of postcolonial society. Additionally, the association between these two directors' works is reflected in their status as independent filmmakers. As I will discuss in each individual film section, Les Saignantes and Juju Factory display acute awareness of their respective contexts of production, even though they were each created "outside the usual institution of productions of French aid to African cinema," as Manthia Diawara points out. ${ }^{28}$

In his discussion of new wave African filmmakers belonging to the Guild, Diawara characterizes their work as bridging political and aesthetic practices, which he locates in the distinct styles of Sembène and Mambéty in a somewhat schematic manner. He writes:

The search for a new image of Africa entails a questioning of the binary opposition that existed between a political and committed cinema, i.e. Sembène's, and an aesthetic avantgarde and apolitical cinema, i.e. Mambéty's. For the Guild filmmakers, the image must partake of politics as well as poetics. ${ }^{29}$

This chapter builds upon Diawara's idea by further examination of how the two films present a new political film language through their engagement with socio-political realities on a formal level. Aboubakar Sanogo's concept of "prospective engagement" articulates a strategy in which films give critical attention to certain historical or socio-political objectives with a clear vision of the future. He defines this concept as the manner in which filmmakers who are "interpellated by situations of dominance present in social and historical reality, inscribe themselves and their

\footnotetext{
${ }^{27}$ La Guilde, "Pour un nouveau cinéma africain," in Afriques 50: singularités d'un cinéma pluriel, ed. Catherine Ruelle (Paris: L'Harmattan, 2005), 270.

${ }^{28}$ Diawara, African Film, 136.

${ }^{29}$ Ibid., 129.
} 
creative act in that reality, situating it in relation to some form of futurity or virtuality." ${ }^{, 30}$ This strategy, Sanogo writes, "has the potential [...] to create or evoke real-life effects (either immediate or deferred) on the politics of representation and/or the agora." ${ }^{31}$ Sanogo provides limited evidence to illustrate his concept, although he lists Abderrahmane Sissako's La vie sur terre (1997) and Bamako (2006), and Jean-Pierre Bekolo’s Les Saignantes and Le Président, as prime examples, since these films carry out in the realm of the film that which cannot be done in the space of historical and geopolitical reality. ${ }^{32}$ Sanogo's idea, with respect to its key aspect of intervention, is helpful in the articulation of a new political film language. While Diawara and Sanogo skillfully highlight engagement with socio-political realities, they do not acknowledge the particular ways contemporary films, such as those by Bekolo, Sissako and other Guild directors, engage with cinema. Indeed, in addition to their specific geopolitical objectives, Les Saignantes and Juju Factory are also concerned with contemporary filmmaking practices and demonstrate a desire to advance African cinema aesthetically and conceptually.

\section{Cinema and the Reinvention of Reality: Les Saignantes}

In his collection of essays, Africa for the Future: Sortir un nouveau monde du cinéma, Bekolo describes cinema as “une étude comparée entre l’existant (le réel) et le possible (la fiction)." ${ }^{33}$ Along with the book's title, this description gives a strong sense of Bekolo's futureoriented approach to the seventh art. Offering what he calls "une radiographie," his films reveal problems that lurk beneath the surface, and imagine an alternative reality, one that is not

\footnotetext{
30 Sanogo, "Certain Tendencies in Contemporary Auteurist Film Practice," 147.

31 Ibid.

32 Ibid., 147-48.

33 Jean-Pierre Bekolo Obama, Africa for the Future: Sortir un nouveau monde du cinéma (Achères, France: Éditions Dagan, 2009), 48. "Cinema is a comparative study between that which exists (reality) and that which is possible (fiction)." (My translation)
} 
necessarily transferable but nevertheless applicable to real life. ${ }^{34}$ His conviction that cinema provides the tools with which to transform reality permeates his works, and Les Saignantes in particular. This film performs the deconstruction and reinvention that Bekolo believes is necessary beyond the fictional world of the film. In its engagement with the issues of the postcolonial state in Cameroon and with its articulation of cinema's central role in working towards a solution, Les Saignantes exemplifies a new political film language.

Les Saignantes performs the process of reinvention through an allegory of cinema. The primary narrative events represent the creation of a film; they revolve around the death of one of the heads of state whose body represents the body of film, and the dismemberment, reassembling, and display of his body correspond to the different phases of film production, from shooting, to editing, to its public release. Through the enactment of making a film, Les Saignantes stages the idea that, like film, reality can be broken down, reconstructed and reshaped; it can be edited. The cinematic allegory is part of the film's larger narrative and aesthetic strategy of self-reflexivity, or the various ways it explicitly draws attention to the fact that it is a film. It deliberately rejects the conventions of realism through aspects of mise-enscène, such as colors and lighting, and through inserts which directly address the spectator. Les Saignantes ruptures the boundaries of conventional modes of filmmaking so as to incite critical awareness, and to expand the narrative and aesthetic possibilities of contemporary African filmmaking.

The film is set in the year 2025 in Yaoundé and imagines what would happen if current socio-political tendencies continue into the future. It demonstrates that the anticipated future state of the society is best, perhaps only, articulated through a dystopia. At the same time, the

\footnotetext{
34 Manthia Diawara, "Interviews Cinéastes," African Film: New Forms of Aesthetics and Politics (Munich: Prestel, 2010), DVD. A radiographie is an " $\mathrm{x}$-ray," or a detailed description.
} 
film's temporal setting allows for the possibility to create meaning in relation to the future since, for Bekolo, "every time you talk about Africa you never talk about the future." ${ }^{35}$ The dystopian portrait conveys a sense of pessimism and despair about a real-world society with a decidedly fragile present, and a future that is even more so, if not implausible. The film acknowledges this fact up front through the first occurrence of on-screen text; prior to the opening scene, the following phrase scrolls out on a screen within the frame, and subsequently appears in white text against a black screen: “Comment faire un film d'anticipation dans un pays qui n'a pas d'avenir?" ${ }^{36}$ By negating the country's future prospects right from the start, the film compels the spectator to consider the present issues that factor into this fear-inducing thought. Rather than being the result of a singular circumstance, the state of society depicted in Les Saignantes is rooted in the abiding concerns of the contemporary situation in Cameroon, notably sociopolitical oppression, and political corruption. ${ }^{37}$ The ills of society are manifest in many ways, such as the incessant nighttime. In an interview with Akin Adesokan, Bekolo draws a metaphorical link between the film's cover of darkness and the sense of being stuck or frozen in time: "It's mainly like we're wandering in a tunnel, and one day there will be light. There will be a new dawn."38

\footnotetext{
${ }^{35}$ Akin Adesokan, "The Challenges of Aesthetic Populism: An Interview with Jean-Pierre Bekolo," Postcolonial Text 4 (May 2008), 3.

36 "How do you make an anticipation film in a country with no future?" English translations are provided by the film's subtitles.

${ }^{37}$ In particular, the film's premise evolved from a social phenomenon in Cameroon in which young women use their sexuality to bed state officials in order to obtain something they, or others they know, want. For Bekolo, it was crucial to feature young women as the main characters in order to approach political issues: "I always say about Les Saignantes that I deal with girls like I deal with cops - it's not really about gender. I like those characters because they could help me tell my story better. Girls are politics for me...And the film is not just about Cameroon; it's about human beings, really. And on a larger scale, [it's about] human corruption." Jean-Pierre Bekolo, interview by Anna V. Keefe, February 14, 2014, The University of Virginia, Charlottesville, VA. For the full text of this interview, see Appendix 2.

${ }^{38}$ Adesokan, "The Challenges of Aesthetic Populism," 2.
} 
Scholars have compellingly analyzed Les Saignantes as a political critique of the postcolonial state; however, the film's self-reflexivity does not sufficiently factor into these analyses. ${ }^{39}$ Rather, studies such as Matthew Omelsky's and Aminata Diabate's articulate the film's political project by focusing on the gender dynamic, and highlight the empowering nature of the female body. ${ }^{40}$ Kenneth Harrow also examines the powerful female figures and situates the film within a broader theme of matriarchy's supplanting of patriarchy in contemporary African films and novels. ${ }^{41}$ Whereas these insightful studies give attention to the female body, this chapter shifts the focus to the male body, especially what it represents in the cinematic allegory. Additionally, existing studies have not yet paid ample attention to the film's engagement with African filmmaking practices, beyond noting its innovative use of genre. Indeed, it is considered the first African science fiction film, but it is precisely the adoption of standardized genres that Bekolo critiques in the film, specifically through the on-screen text. Les Saignantes' active questioning of genre and experimentation with form signifies an effort to transform African cinema.

The film's first sequence is an erotic encounter between one of the Saignantes, Majolie, and the Secrétaire Général du Cabinet Civil, or SGCC. ${ }^{42}$ The SGCC suffers a post-coital heart

\footnotetext{
${ }^{39}$ See Taiwo Adetunji Osinubi, “Cognition's Warp: African Films on Near-Future Risk,” African Identities 7, no. 2 (May 2009): 255-74; Olivier Tchouaffe, "Homosexuality and the Politics of Sex, Respectability and Power in Postcolonial Cameroon," PostAmble 2, no. 2 (2006): 4-15.

${ }^{40}$ Following Donna Haraway's concept, Omelsky reads the Saignantes as cyborgs. Diabate argues that the film is an adaptation of a Mevoungou ritual. Omelsky, “Jean-Pierre Bekolo's African Cyborgian Thought," Nka: Journal of Contemporary African Art 31 (Fall 2012): 6-21; Diabate, "Jean-Pierre Bekolo's Les Saignantes and the Mevoungou: Ambivalence Towards the African Woman's Body," in Women, Gender, and Sexualites in Africa, ed. Toyin Falola and Nana Akuah Aponsah (Durham: Carolina Academic Press, 2012): 21-38.

${ }^{41}$ Kenneth W. Harrow, "What's an Old Man Like You Doing with a Saignante Like Me?" in Facts, Fiction, and African Creative Imaginations, ed. Toyin Falola and Fallou Ngom (New York: Routledge, 2010), 190-206.

42 The SGCC is actually a combination of two powerful political figures in Cameroon. One is the SGPR, the Secrétaire Général du Président de la République, and the other is the DCC, the Directeur du Cabinet Civil; the SGCC is a mix of these two people. The SGPR runs the presidency, and the DCC runs the President's private life. Regarding the various acronyms, Bekolo states: "I like that these names are produced by the system, and they become symbols. These names are very cinematic, too." The term DGP is another invention of Bekolo and contributes to the science fiction aesthetic strategy. Bekolo, interview.
} 
attack and dies, so Majolie, with the help of Chouchou, her fellow Saignante, disposes of the elderly man's body. They take it to a butcher, who hacks it into pieces. Keeping only the head, the Saignantes decide to hold a Deuil de Grande Personnalité, or DGP, since, as one of the inserts informs us, death is an occasion to celebrate in this dystopian society. ${ }^{43}$ The deceased man must be on display at the DGP, so Majolie and Chouchou hire a mortician to reconstitute the SGCC by attaching his head to the body of an unclaimed corpse. In the meantime, the Saignantes' mission attracts the attention of a young police inspector, who naively believes in the effectiveness of the police force and justice; according to the police chief, investigating is futile and dangerous. Despite the chief's warnings, the inspector alerts the Ministre d'État (Minister of State) that the girls are preparing a coup, although the Minister laughs when he learns that the suspects are women. While at the morgue, the Saignantes cross paths with the Minister, which inspires them to make him their next, and ultimate, target. They meet the Minister at the SGCC's DGP, and devise a contract stipulating that they will receive a large sum in exchange for sex. He eventually backs out of the deal, although Majolie and Chouchou confiscate the money. In the climactic moment of the film, the Saignantes fight the Minister and use their supernatural powers to successfully "neutralize the beast," rendering the man helpless. ${ }^{44}$ Nonetheless, the cover of darkness remains at the end of the film, indicating that the ills of society persist.

As this brief plot summary indicates, the Saignantes engage in transactional sex and their activities drive the narrative forward. ${ }^{45}$ But beyond their sexuality, they are also equipped with the supernatural Mevoungou (mevungu in Beti), which is an ancient, secret practice exclusive to

\footnotetext{
43 A WIP, or Wake of an Important Person.

44 "Neutraliser la bête," stated by the narrator in voice-over.

45 As Diabate points out, most published works on the film refer to Majolie and Chouchou as prostitutes, however, transactional sex best describes their activities since they "use sexual favors to obtain business deals and to gain leverage in Cameroonian high social and political ranks." Diabate, “Ambivalence Towards the African Woman's Body," 22.
} 
Beti women. ${ }^{46}$ It consists of a nightlong ritual led by initiated, mature women in the community, and aims to valorize female power by celebrating the female sexual organs. The ritual is used as an intervention for those who are experiencing hardship, whether it is on an individual or collective level. ${ }^{47}$ The purpose of the ritual is a means of protection from evil, and/or purification for wrongdoing, with the overall aim of restoring life in the community; Bekolo refers to it as a "rite réparateur." A8 Anthropological studies by Marie-Paule Bochet de Thé and Jeanne-Françoise Vincent show that the ritual is primarily a means of protection and retaliation against male domination, while Philippe Laburthe-Tolra claims that the Mevoungou allows for the elimination of evil forces for both men and women. ${ }^{49}$ Laburthe-Tolra's study shows that after the ritual has been carried out, "it is expected that a period of "extraordinary prosperity' will come."50 In Les Saignantes, the presence of the Mevoungou is a combination of these perspectives in that the society at large suffers from a dystopian reality, which is due to a form of state domination that invades every aspect of life. The Mevoungou empowers the Saignantes to challenge the men who embody absolute power, a feat from which all members of society may benefit.

The Mevoungou not only allows the Saignantes to carry out their mission of purifying the corrupt postcolonial state, it also relates to the cinema conceptually and symbolically. If the Mevoungou is in essence a purifying and restorative force, cinema is the ultimate rite réparateur. By conflating the Mevoungou with cinema, the film further emphasizes cinema as the solution to

\footnotetext{
46 Olivier Barlet, "Entretien d'Olivier Barlet avec Jean-Pierre Bekolo à propos de Les Saignantes: Être à la fois africain et contemporain," Africultures (August 8, 2005), http://www.africultures.com/php/?nav=article\&no=3944. The Beti are an ethnic group that resides in the rainforest regions of Cameroon and neighboring central African countries. Bekolo himself is Beti, although he admits to never having heard of the Mevoungou until discovering it in Philippe Laburthe-Tolra's 1986 novel, Le Tombeau du Soleil.

${ }^{47}$ Cheryl Toman, Contemporary Matriarchies in Cameroonian Francophone Literature: 'On est ensemble' (Birmingham, AL: Summa Publications, 2008), 116-17.

48 Barlet, "Entretien d'Olivier Barlet avec Jean-Pierre Bekolo à propos de Les Saignantes."

49 In Toman, Contemporary Matriarchies, 116.

50 Ibid.
} 
socio-political transformation. First, the female specificity of the Mevoungou forges a tie to the medium of cinema in their mutual power of creation. Cinema is life giving; it creates a world that is born again every time that it is viewed. Correspondingly, the Mevoungou is rooted in a matriarchal position, and references to menstruation and motherhood occur visually throughout the film as well as in the dialogue. Even the term "Saignante," a creation of Bekolo's, clearly evokes the idea of menstruation. ${ }^{51}$ In addition to the female-centric qualities that align the Mevoungou and the cinema, the film's introductory definition of the Mevoungou further denotes the comparison. The voice-over narrator first introduces the magical force following the film's opening sequence, and presents it mostly by telling the viewer what it is not, which makes the qualities in the affirmative tense stand out:

Mevoungou n'est ni un être vivant, ni un objet. Mevoungou n'est pas un lieu, encore moins un moment. Mevoungou n’est pas non plus un désir, surtout pas un état. Parce que Mevoungou est une chose qu'on voit, et qu'on vit, sans pour autant pouvoir la définir... ${ }^{52}$

After the initial qualities explaining what it is not, the first defining feature in the affirmative tense perfectly characterizes cinema: "Mevoungou is something that we see." Likewise, cinema is most certainly something that we see. The next quality, "une chose [...] qu'on vit," aptly describes the manner in which the Mevoungou inhabits the Saignantes; it possesses them, and propels their actions.

The actions of the Saignantes not only drive the narrative forward, but they also represent the process of film creation in the allegory of cinema. The film's opening-the first phase of the

\footnotetext{
${ }^{51}$ Unfortunately, the English translation of the term, "bloodette," sometimes translated as "bloodletter(s)," does not have the same female-centric resonance as the French term.

52 "Mevoungou is neither a living being nor a thing. Mevoungou is not a place, much less a moment. Mevoungou is neither a desire nor a state of mind. Because Mevoungou is something we see and experience but cannot quite define..."
} 
cinematic allegory-sets a provocative tone by depicting an erotic scene between Majolie and the SGCC. This type of moment in film often occurs after a gradual build-up of tension and desire, but its position in Les Saignantes precedes any sort of prelude, which constitutes a rejection of the conventions of narrative. Beyond its unusual position in the film, the scene "pushes the erotic boundaries in West African cinema," according to Diabate, and features a beautiful, young woman with an elderly man ${ }^{53}$ She is fully in control of the situation, a power dynamic that is visible in her physical position on top, and in her forceful, deliberate movements. Wearing only a bra, Majolie does a series of warrior-like poses while dangling in the harness, followed by hip swivels and pelvic thrusts in standing and kneeling positions. In juxtaposition with her sexuality and agility, the SGCC lies motionless with his arms feebly outstretched towards her. He suffers a heart attack and dies, although one suspects that his death was not entirely accidental. In a key moment during the scene, an insert frames Majolie in a close-up shot; her arms are fully extended, with her index and middle fingers outstretched in the form of a gun (figure 1). Although it is very brief, the shot effectively stands out due to the fact that Majolie is facing in the opposite direction from that during the rest of the sequence. The camera maintains its side angle position whereas the orientation of her body has rotated to face towards his feet instead of his head. A sound resembling a gunshot accompanies her movements, suggesting that she fired a shot, albeit invisible.

\footnotetext{
53 Diabate, "Ambivalence Towards the African Woman's Body," 29-30. Diabate observes how the scene undoes "the normalized hierarchies of gender and seniority" in the West African imaginary through a reversal of the "conventional gender dynamic."
} 
Fig. 1

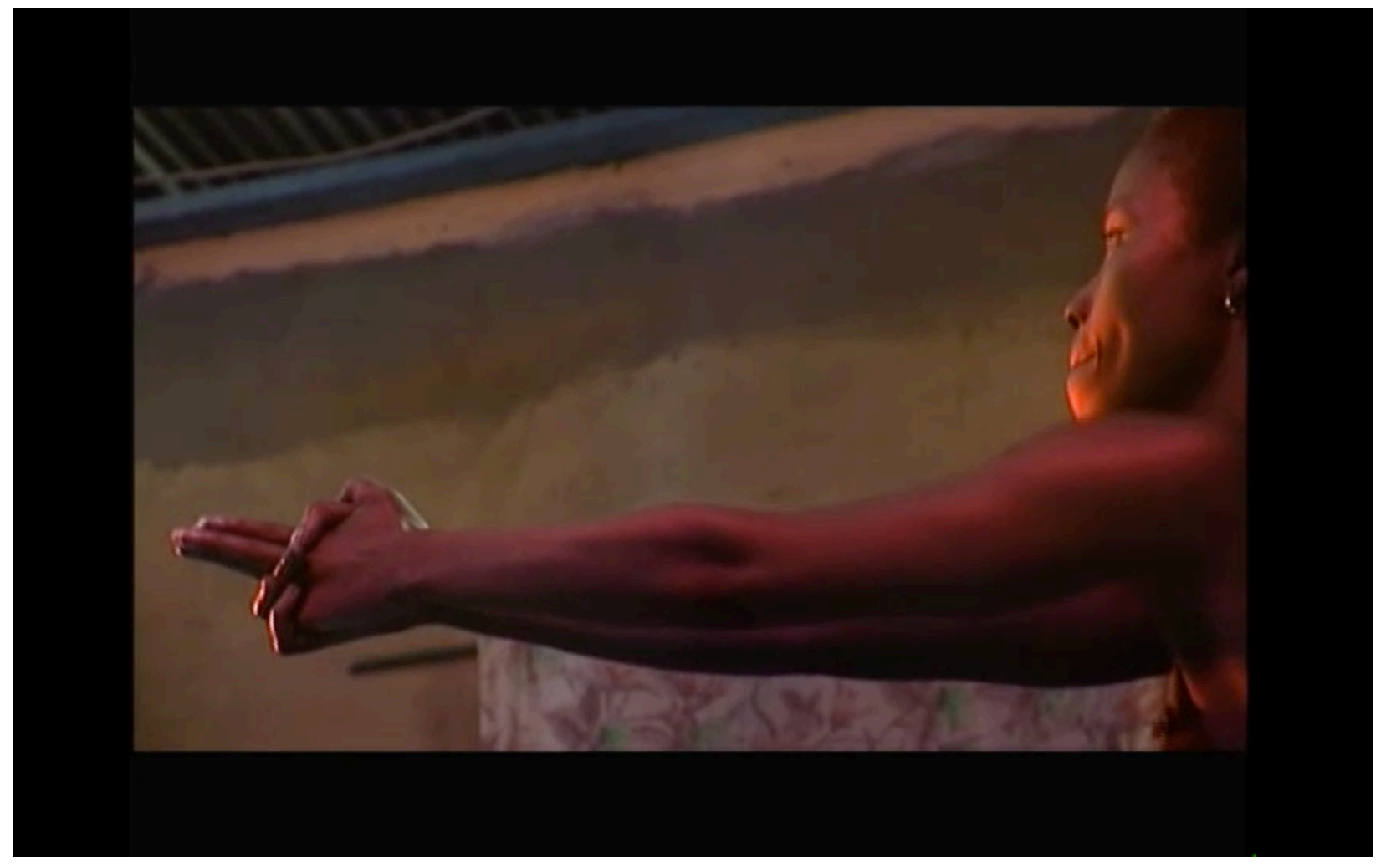

While at first it is unclear whether Majolie's movements are designed to cause physical harm, it is revealed in a later sequence as Majolie re-enacts the position du tir (shooting position) for Chouchou, telling her that this is the la phase (number) that she used on the SGCC. In this sequence, which takes place in her bathroom, Majolie states the words position du tir as she enacts it, which involves squatting deeply while her arms, extended above her head, unfold into the form of a pointed gun. Majolie's utterance and gesture are repeated a couple of times, to emphasize their importance. After performing the gesture for Chouchou, Majolie invites her to try. Chouchou crouches down and as she rises back to standing she begins a series of pelvic thrusts; Majolie joins in, and the two girls act out the movements simultaneously (figure 2), including the position du tir. Next, Majolie reappears in the harness from the opening sequence, does a series of acrobatic flips, and then swings around with her arms outstretched and her 
fingers in the shape of a gun, as the narrator states in voice-over: "On aiguisait notre arme."54 The "synchronization and precision" in Majolie and Chouchou's movements in the bathroom sequence serve to "clarify the element of intention or calculation" of Majolie's movements in the opening sequence with the SGCC, as Omelsky notes. ${ }^{55}$ The same music plays in the soundtrack during both sequences, which bridges Majolie's actions in each sequence. Additionally, the fact that the narrator qualifies their physical movements as their arme, or weapon, makes it clear that the SGCC's death was deliberate.

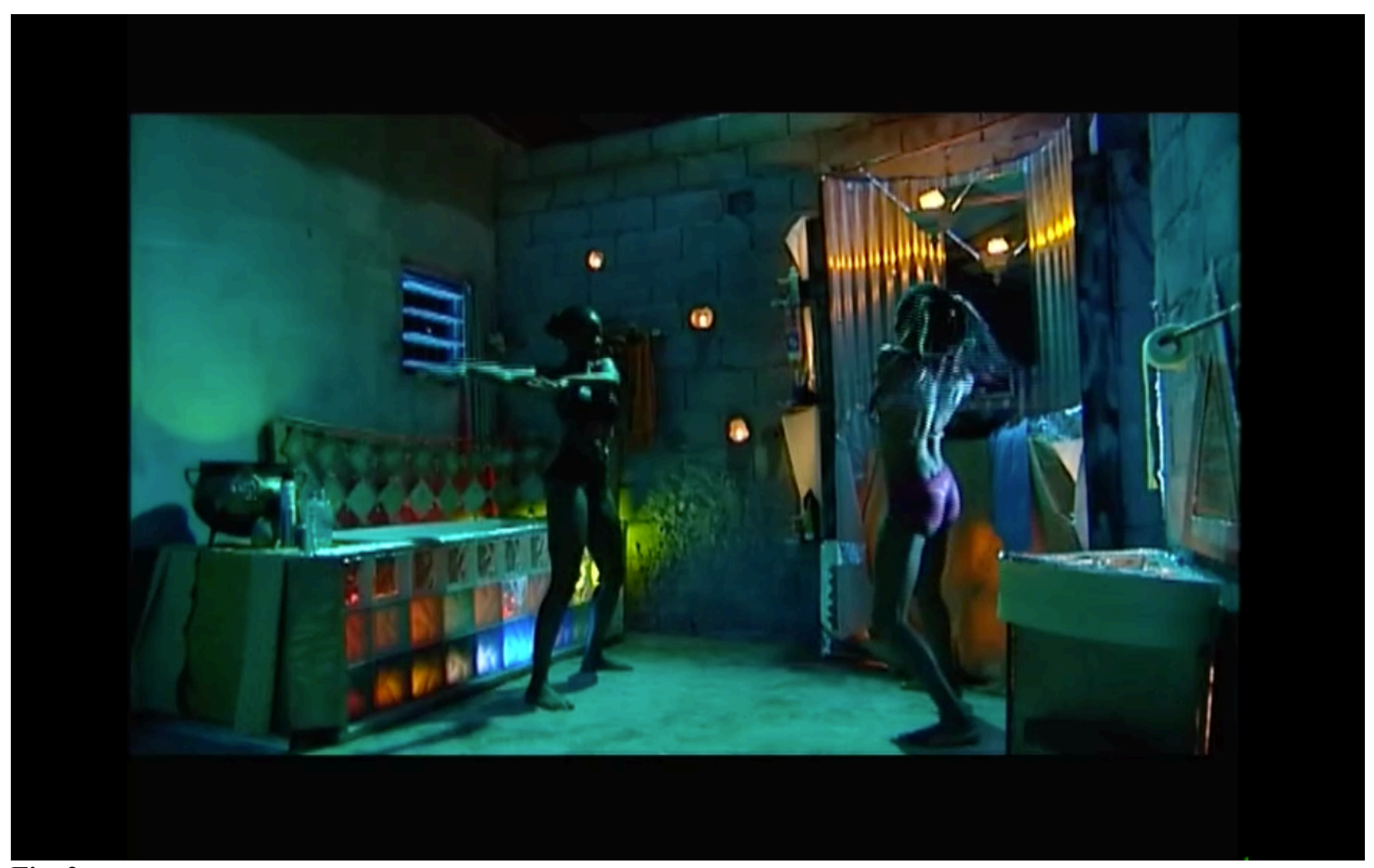

Fig. 2

The term position $d u$ tir, shooting position, alludes to the notion of filming. The French verb tirer is embedded in the term, which means to shoot or fire a gun. It is undeniable that the English translation of the term points to the act of filming: one shoots a film. Thus, Majolie's "shooting position" mimics the act of shooting a film, the initial phase in the cinematic allegory.

\footnotetext{
54 "We were sharpening our weapon."

55 Omelsky, “Jean-Pierre Bekolo’s African Cyborgian Thought," 18.
} 
The same does not hold true in French, as the verb used to refer to the act of filming is not tirer but tourner, although according to Sergei Eisenstein, filming pulls objects and/or actions from life, which implicates the verb tirer in its sense of "to pull." ${ }^{, 56}$ For Eisenstein, the act of filming is inherently violent as it viciously tears a piece of the world from its natural place. This implies that the camera is an instrument of violence, an idea that has many iterations in film theory. André Bazin posits that the function of the camera is an act of embalming the dead. ${ }^{57}$ Along these lines, William Rothman highlights the camera's capacity to prompt the violence: "In fiction films, violence happens on cue, as if the camera were a gun, and the director, offscreen, were pulling the trigger." ${ }^{58}$ Even on the basis of language, filming lexicon is tinged with violent overtones: to shoot a film or sequence, and to cut apart or to make cuts (as in editing). The inherent violence of cinema's terms stem from its precursor, photography, and its fundamentally violent vocabulary, such as prendre une photo/to take a picture; capturer une image/to capture an image. These latter terms call to mind the idea that aligns capturing one's image with stealing one's soul. ${ }^{59}$ Indeed, Majolie claims the subjectivity of the SGCC by killing him, and cinemaoperating on a symbolic level-mediates this process.

By enacting the "shooting position," Majolie embodies the weapon-the Mevoungou or camera-and the SGCC becomes the body of film. Even the harness that undergirds her acrobatic movements evokes a mechanical apparatus, furthering the reference to a camera and its various appendages. Through her body's merging "with machine and technology," Majolie "has killed

\footnotetext{
${ }^{56}$ In William Rothman, The "I" of the Camera: Essays in Film Criticism, History, and Aesthetics, 2nd ed. (Cambridge: Cambridge University Press, 2004), 350.

${ }^{57}$ André Bazin, “Ontologie de l'image photographique," Qu'est-ce que le cinéma? (Paris: Les Éditions du Cerf, 1994), 14. "La photographie ne crée pas, comme l'art, de l'éternité, elle embaume le temps, elle le soustrait seulement à sa propre corruption."

58 Rothman, The "I" of the Camera, 356. In a similar vein, Paul Virilio draws a comparison between a battleground and a filming range wherein the weapon beholder's eye is the driving force of a weapon: "Pour l'homme de guerre, la function de l'arme c'est la fonction de l'œil." (For a man of war, the function of the gun/weapon is the function of the eye.) Paul Virilio, Guerre et Cinéma (Paris: Éditions de l'Étoile, Seuil, 1984), 26.

59 Rothman, The "I" of the Camera, 352.
} 
this grand homme." ${ }^{60}$ Majolie targets this figure of authority, and, more broadly, structures of power, an act that relates to Teshome Gabriel's call for a "'guerrilla cinema'-one in which the camera is likened to a rifle as the 'inexhaustible expropriator of image-weapons' and the projector is likened to a gun that can shoot twenty-four bullets a second."61 The notion of the camera-weapon, and also image-weapon, applies to Les Saignantes' larger political project of seeking to transform reality. Here, Majolie captures that reality through the "shooting position" and next enacts transformation in the ensuing phase of the allegory of cinema.

In the next stage of the cinematic allegory, the Saignantes carry out the symbolic act of montage by delivering the SGCC's corpse to a butcher to be cut up into pieces. In film production, cutting up the film corresponds to the stages of editing (or montage), which entails cutting up the filmic body, deciding which segments to keep or discard, and how to piece them together. The warehouse in which the butcher's place is located is laden with thick haze and is tinted in somber green light, accentuating a sense of putrefaction. Raw cuts of meat in plastic sacs circulate on a mobile chain around the space, like prints hanging on a line in a darkroom. The butcher is slicing up heaps of meat with a chainsaw upon their arrival. Chouchou lures the butcher to the meat in a hyper-seductive manner, and she and Majolie tuck wads of cash into his blood-spattered apron to entice him to look past the fact that he is dealing with human flesh. He raises a machete and is about to begin the task when Chouchou interjects, pointing out the rusty quality of his machete and insisting that he use "le coûteau en inox" instead. ${ }^{62}$ Majolie, however, reassures him to proceed with the machete. Within the broader context of cinematic allegory,

\footnotetext{
${ }^{60}$ Omelsky, “Jean-Pierre Bekolo's African Cyborgian Thought," 18. Omelsky also identifies the erotic sequence as a salient moment in which Majolie's body merges with machine and technology, but he is referring to the idea of cyborgs rather than the camera.

${ }^{61}$ Teshome Gabriel, Third Cinema in the Third World: The Aesthetics of Liberation (Ann Arbor: UMI Research Press, 1982), 7.

62 The "stainless steel knife."
} 
these butcher knives might be read as the blade of the editor. Even though Les Saignantes was shot digitally, and therefore the film's editing does not involve any physical cutting, the film consistently foregrounds cinema by drawing the viewer's attention to the techniques which are specific to the seventh art. Indeed, the notion of butchering in relation to montage connects to the editing style of Les Saignantes, which favors an abrupt style instead of seamlessness, like it has been hacked with a machete instead of cleanly sliced with stainless steel. For example, the film uses jump cuts, discontinuous shot arrangements, and slow- and fast-motion techniques, akin to music video clips. In fact, one scene exemplifies the music video editing style as it depicts Majolie and Chouchou dancing and trying on clothes in front of a mirror in Chouchou's bedroom. $^{63}$

In the narrative action of the film, the Saignantes' move to dismember the SGCC's body is a means to falsify it, a process brought to completion with the help of a mortician. The SGCC's body must be on display at the Deuil de Grande Personnalité (DGP), so Majolie, Chouchou and the mortician negotiate a deal to locate "un corps qui va avec la tête" among an array of unclaimed corpses at the morgue. ${ }^{64}$ Consistent with the sequence at the butcher's, key elements of the mise-en-scène evoke phases of the film production process. One shot in particular frames the three characters who appear phantomlike as they approach the entrance to the morgue (figure 3). In striking contrast to the cool, subdued atmosphere of the exterior, the interior of the morgue is bathed in electric, red light, a defining characteristic of the light conditions for developing images in a darkroom. Again, despite the fact that Les Saignantes was

\footnotetext{
${ }^{63}$ The song that plays during the sequence is "Vulindlela" by Brenda Fassie, a South African Afropop singer who was known for her ardent anti-apartheid stance. Fassie's music video for the song features a monochromatic color scheme with select hues that stand out, an intertextual reference with the use of color in Les Saignantes and the music video-like sequence in particular. The music-video style stems from Bekolo's work editing video clips (for artists such as Les Têtes Brûlées and Manu Dibango), as well as his training in film editing, before he began making feature-length films.

64 A "body that matches the head."
} 
shot digitally, this element reflects a conscious play with the notion of film, and a move to evoke its artificial, constructed status. In addition to the vivid color and its central position in the shot, the frame of the window within the frame of the image evokes cinema in a self-reflexive manner.

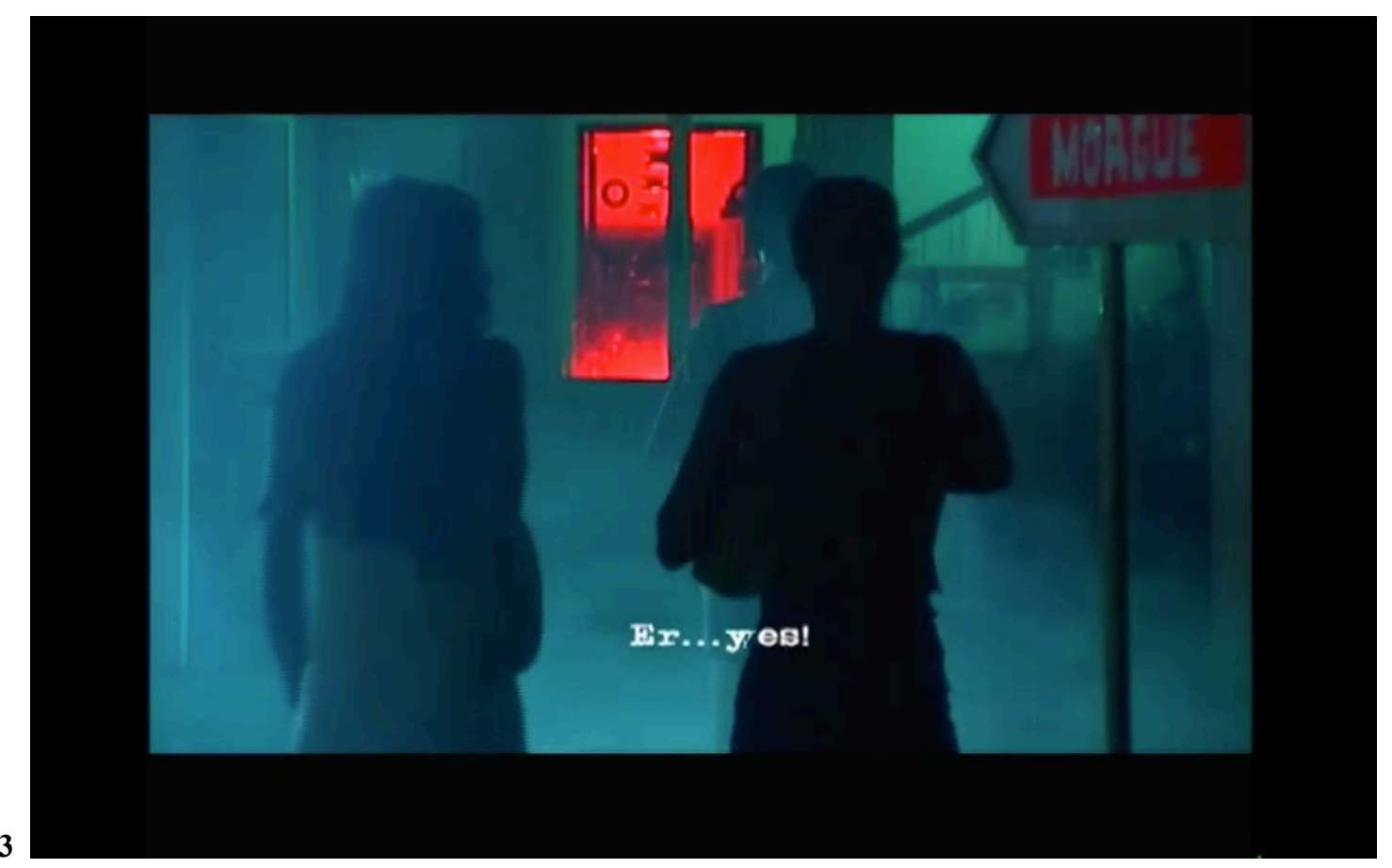

The saturated colors and lighting throughout Les Saignantes indisputably have a highly constructed quality. They call attention to the artificiality of (the) film, and correlate to its aesthetic strategy of deliberately rejecting the conventions of realism. Cool hues, which dominate the color scheme, are contrasted with outrageous, unnatural shades, such as the red in the above shot. The prevailing use of greens and blues paint an atmosphere of fantasy and horror, key characteristics of the dystopian setting. ${ }^{65}$ In addition, the film's low-key lighting, incessant darkness/nighttime, steam-filled atmosphere, and repetitious soundtrack create a sense of stagnation. The color distribution in the above shot emphasizes this fact by signifying that the living are more dead than alive and vice versa, a condition that entrenches the society's

\footnotetext{
65 This predominant color scheme and the atmosphere that it creates are reminiscent of Luc Besson's visual style in films such as Subway (1985), La Femme Nikita (1990), and The Fifth Element (1997).
} 
inhabitants in a zombie-like state. The voice-over narrator makes a similar observation when she describes the citizens: "les morts et les vivants se confondent." presents a profound metaphor for life in the postcolony. In On the Postcolony, Achille Mbembe posits the "zombification" of both the victims and perpetrators of oppression who are forced to share a living space: "This zombification means that each has robbed the other of vitality and left both impotent (impouvoir). ${ }^{, 67}$ The key distinction between Mbembe's idea and the film is that the Saignantes retain vitality-embodying the powerful force of the Mevoungou-while rendering the state officials powerless.

In Les Saignantes, the two young women hold power over men who represent the ruling elite, a power dynamic that encourages the viewer to question the larger structures of power in place. The film's attention to the gaze in the sequence at the morgue illustrates this subversion of power, while also advancing the phases of the allegory of cinema. The mortician attempts to locate a close bodily match to attach to the head of the SGCC. Meanwhile, the glass case next to the mortician's desk catches Chouchou's eye. It contains human body parts dangling from pieces of string, including a hand, a brain, and a penis (figure 4). Framed in a close shot, Chouchou's gaze upon the immobile, free-floating parts signifies that of a film editor's gaze on individual shots during the editing process. The shot cuts to an insert of Chouchou's eyes (figure 5), which further echoes the close look of a film editor at work, whose cutting and piecing together manipulates the body of film. This is the closest the camera gets to any of its subjects over the course of the film and its proximity highlights her gaze. Fixing her eyes upon the male genitalia entails a reversal of the gaze as it is typically deployed in narrative film, by swapping the bearer

\footnotetext{
66 "It's impossible to tell the living from the dead."

${ }^{67}$ Achille Mbembe, On the Postcolony (Berkeley: University of California Press, 2001), 104 (italics in original). Akin Adesokan observes that Bekolo's works and Achille Mbembe's writings are complementary, a connection that Bekolo acknowledges. Adesokan, "The Challenges of Aesthetic Populism," 11.
} 
and object of the look. These shots exaggerate this inverted gesture through the display of a man's dissected flesh. No longer a whole person but merely an array of parts, the male is deprived of subjectivity, whereas the Saignantes occupy a position of power. This idea connects to Laura Mulvey's position that in order for cinema to move away from phallocentrism it must relinquish its insistence on concealing the processes of production. ${ }^{68}$ Les Saignantes operates along these lines by exposing the film as an artificial construction in order to provoke the viewer. Like Chouchou's close gaze, the viewer is encouraged to scrutinize the film's parts so as to question the larger structures of power in place.

Fig. 4

Fig. 5
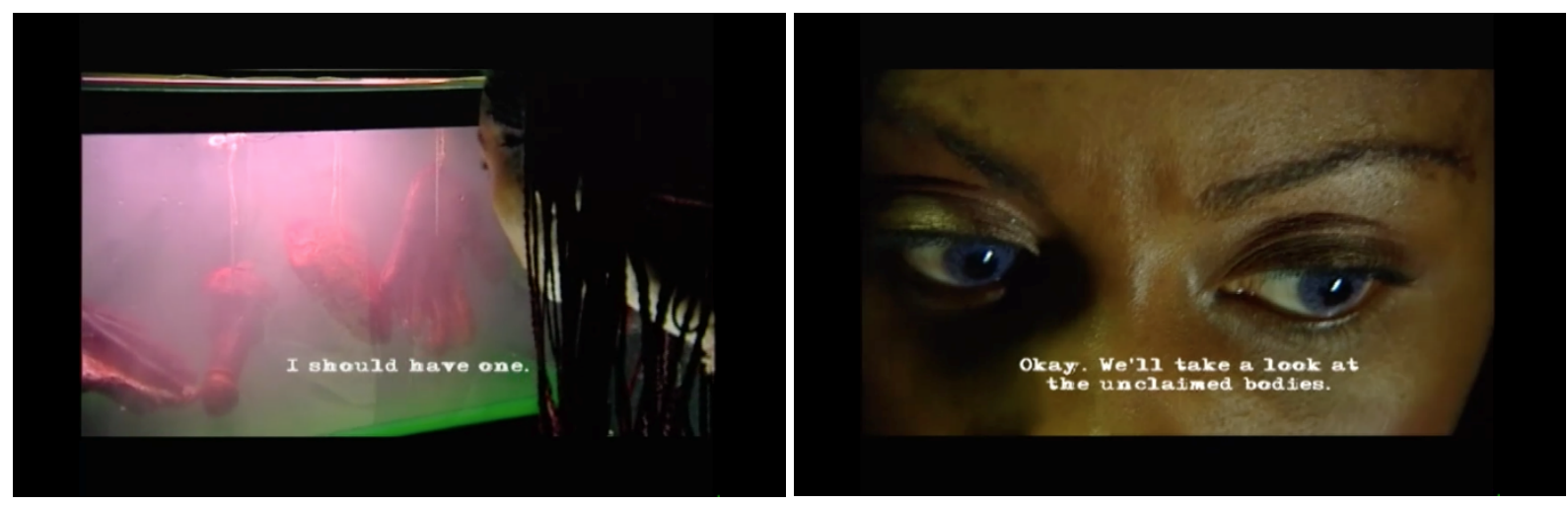

In the culmination of the cinematic allegory, the DGP (Deuil de grande personnalité) bears striking resemblance to a film premiere. For the inhabitants of this dystopian society, the death of a grande personnalité, or VIP, is a fêted occasion, necessitating a grand event. Even though the SGCC's death prompts a celebration, the event has far less to do with the deceased than with the event itself, which is a spectacle revolving around food and drink, and the opportunity to see and be seen, as at a movie premiere or gala. The elements of the mise-enscène, including a red carpet, spotlight, and cheering crowds are all suggestive of a movie premiere, albeit for one incongruous detail in the background: a red and white sign with an arrow

${ }^{68}$ Laura Mulvey, "Visual Pleasure and Narrative Cinema," Screen 16, no. 3 (Autumn 1975): 6-18. 
that reads "Morgue" (figure 6). The sign remains visible throughout the somewhat lengthy duration of the shot, a reminder of the absurdity of the celebration. Further, the auditorium in which the wake is held is arranged more like a movie theater than a traditional wake setting, due to the stadium-style seating. The crowds of people ostentatiously welcome and, at the end, see off the Minister of State as if he were a celebrity.

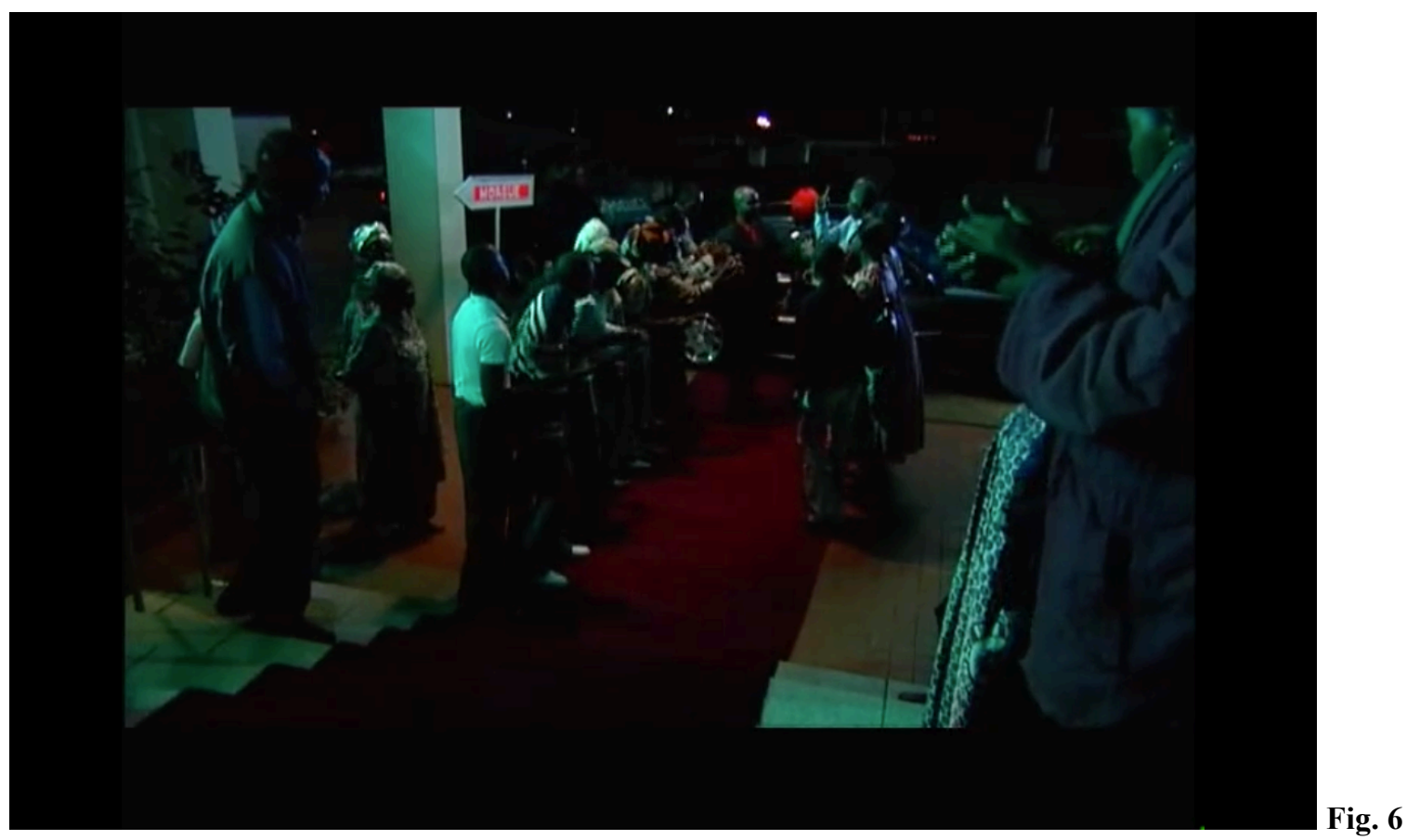

In the cinematic allegory, filmmaking intersects with the representation of filmmaking, a project that is inherently political since it involves the body of a politician. Indeed, the allegorical film being shot, edited, and shown is (of) the SGCC. Upon carrying out their project with this political figure, the Saignantes move on to their next one. The SGCC's DGP presents them with the opportunity to ensnare their prey as they embark on their next, and final, mission: to take down the Minister of State. This project does not correlate to cinema to the same degree as with the SGCC. Rather, it involves fully dismantling the political system, which the Saignantes accomplish first through seduction, but ultimately by fighting the Minister, empowered in their endeavors by the force of the Mevoungou. 
As a public spectacle, and one that involves death and the experience of pleasure, the depiction of the DGP relates to Achille Mbembe's "economy of death," which further situates the film's project within a discourse of power. Mbembe's "economy of death" details the economic and political non-life of citizens in the postcolony, an idea that resonates with the film's portrayal of the postcolonial state as a land of the undead ${ }^{69}$ In the "economy of death," death is performed for public pleasure; the subject, who is deemed a threat to the established order, is sacrificed in a public setting, which serves as a demonstration of the ruling body's absolute power. ${ }^{70}$ As Isaac Joslin points out, this performance paradoxically "trivializes life" but "allows for the experience of pleasure." In Les Saignantes, the death of the SGCC occurs in a private setting, but his death provides an occasion for public enjoyment. Along with the film's depiction of funerals as an extravagant occasion involving spectacle and pleasure, one of the instances of on-screen text advertises this aspect of death by questioning its relationship to artistic representation: "Comment faire un film d'horreur dans un endroit où la mort est une fête?" 72 According to Mbembe, the "economy of death" illustrates an underlying aspect of life in the postcolony: its "taste for the theatrical." ${ }^{, 73}$ The idea of life as a theatrical performance relates to Les Saignantes' self-reflexive qualities, explicitly foregrounding the fact that it is a film and, therefore, an artificial construction.

Les Saignantes consistently exposes its status as a film through deliberately rejecting the conventions of realism. The film takes this a step further by explicitly reminding viewers of the narrative process in which they are engaged through the use of on-screen text. The written

\footnotetext{
${ }^{69}$ Mbembe, On the Postcolony, 115.

70 Ibid.

71 Isaac Joslin, "Baroque Practices in Postcolonial African Literature and Theory: From Achille Mbembe's On the Postcolony," International Journal of Francophone Studies 12, no. 4 (2009), 642.

72 "How do you make a horror film in a place where death is a party [or cause for celebration]?"

73 Mbembe, On the Postcolony, 115.
} 
phrases bookend the film, and also appear intermittently during the latter half of the narrative, deliberately breaking the continuity of the action. Using the same linguistic formula, the text poses rhetorical questions about the link between artistic representation and social, political, and cultural realities with respect to its setting. For instance, one phrase asks, "Comment faire un film d'action dans un pays où agir est subversif?",74 In addition to action, they refer to anticipation (a sub-genre of science fiction), horror, romance, and crime genres, respectively. The text is both inside and outside the narrative, as it appears first within the film's diegetic space, in fluorescent green font on a large electronic screen situated in a parking lot (figure 7).

Fig. 7

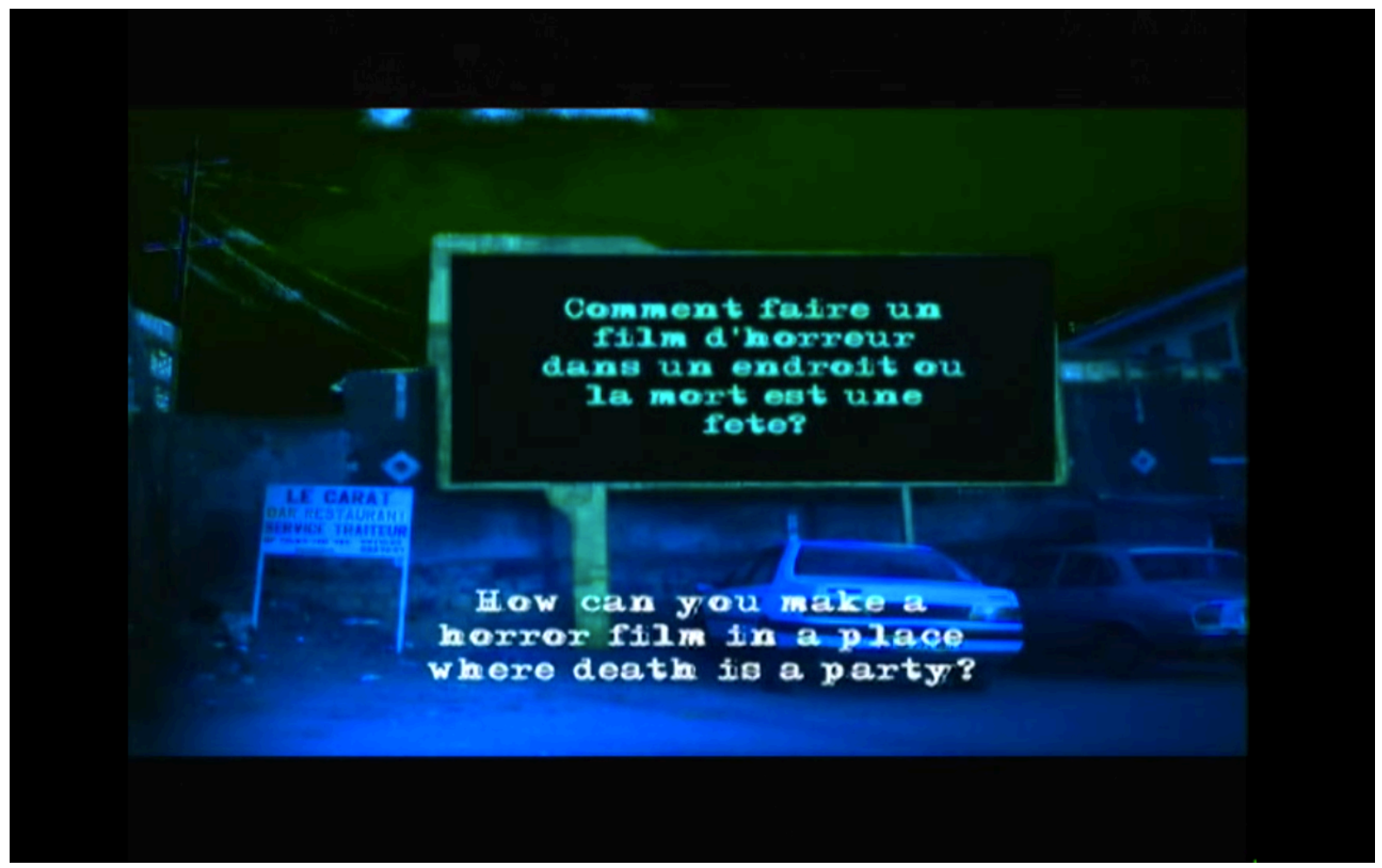

Next, the same text appears outside the diegesis, in white font on a black screen, fully occupying the frame (figure 8). By appearing both within and outside the diegesis, the text directs the viewer's attention away from and also towards the film. As Tom Conley puts it, writing in film

\footnotetext{
74 "How do you make an action film in a country where to act is subversive?" The inserts do not use accents in French words that require them in their correct spelling.
} 
"generate[s] the elemental fissure; it leads to and draws away from image and voice." $" 75$

Concurrently drawing attention to and from the film, the written formulas comment on the relation of the narrative action to its context of production, while also consciously playing with cinematic conventions.

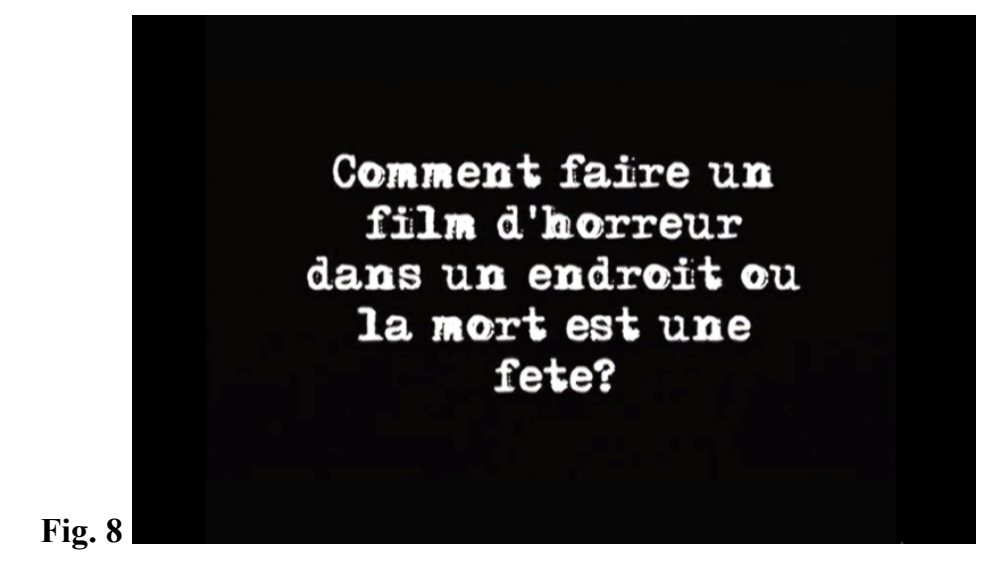

First, the on-screen text literally spells out the inherent issues with the use of standardized genres in relation to the film's geopolitical context. As written text on a screen within the frame, it exemplifies the idea of screenwriting, and displays the questions that factor into the process specifically with respect to Cameroon, and, more broadly, contemporary Africa. For Bekolo, certain cinematic codes are reliant upon contingent realities, otherwise, a film risks becoming a cliché, or a mere repetition. Alluding to the long-standing popularity of certain genres in Africa, which include westerns and martial arts films, Bekolo explains, "Genre films are part of our culture, as Africans...but the thing is always not just to use them, but to question them in relation to the choices we have to make in the context of African cultures. ${ }^{976} \mathrm{He}$ illustrates this idea with an anecdote specific to Cameroon: "I always like to say, how do you have a car chase in a country where you never have gas? Each time you call the police, they ask you if you have gas

\footnotetext{
75 Tom Conley, Film Hieroglyphs: Ruptures in Classical Cinema (Minneapolis: University of Minnesota Press, 2007), xxx.

${ }^{76}$ Adesokan, "The Challenges of Aesthetic Populism," 3.
} 
money [so if they come they can be paid]!"77 This example echoes one of the film's written formulas, "Comment faire un film policier dans un pays où on ne peut pas enquêter?"78 Further, the reference to crime films is pertinent at a time when we are witnessing the rise of genre films by African directors, particularly the crime thriller. ${ }^{79}$ With respect to the broader landscape of African filmmaking, the use of less commonly used genres often leads critics and artists to consider it as aesthetic innovation. "The typical thing is to say if you use any of the genres, then you have moved African cinema to the next level," states Bekolo. ${ }^{80}$ Through the written formulas, Les Saignantes resists a passive adoption of cinematic codes and actively exposes its artistic limits with respect to its setting.

The on-screen text draws attention to the film's context of production, and it also advertises how film can (attempt to) reach the viewer. Aside for being "writing within the field of the moving image," the text talks about the making of Les Saignantes, an aspect that illustrates Tom Conley's concept of film hieroglyphs. ${ }^{81}$ According to Conley, the presence of writing can "make obvious how [a film's] modes of fabrication are working." 82 An obvious example is the sign (as in a street sign, or a sign indicating a business establishment, etc.), which appears in the above shot of the digital billboard (in figure 7). In this image, the presence of the sign for $L e$ Carat and the screen on which the text appears within the film's frame explicitly announces that the digital message is a sign, one that is designed to inform or instruct. When the image cuts to

\footnotetext{
${ }^{77}$ Bekolo, interview. In his interview with Adesokan he gives an additional example: "It's true that sometimes things come across as caricatures, like when I see an African film where the investigation proceeds just like in an American film. How can you make that kind of film in a situation when information is held back by government officials?" Adesokan, "The Challenges of Aesthetic Populism," 3.

78 "How can you make a crime film in a country where investigation is forbidden?"

${ }^{79}$ For example, recent crime thrillers such as Viva Riva! (2010) by Congolese director Djo Tunda Wa Munga, and L'Absence (2009) by Senegalese-born director Mama Keïta had international releases.

${ }^{80}$ Adesokan, "The Challenges of Aesthetic Populism," 3.

${ }^{81}$ Conley, Film Hieroglyphs, xxiv.

${ }^{82}$ Ibid., xxiii.
} 
the same text in white lettering on a black screen (figure 8), the film renders manifest the screen as a flat surface, a blank slate for transmitting information. Along these lines, Gilles Deleuze observes how "the frame teaches us that the image is not just given to be seen. It is legible as well as visible. ${ }^{, 83}$ Here Bekolo makes this function explicit through his use of the frame to serve "as an opaque surface of information." ${ }^{84}$ In this literal signposting, the film displays how the image can transmit a message, provoke questions, and incite critical awareness. All of these processes connect to Bekolo's political project in Les Saignantes and, as we shall later see, Bakupa-Kanyinda's project in Juju Factory.

The on-screen text also serves as an ironic reference to the film's production format. The text's appearance in white letters against a black screen (as in figure 8) evokes the silent film era and the use of title cards. As we saw in the previous chapter, Bekolo stylistically evokes early cinema in his film Aristotle's Plot as a means to foreground issues related to the film's context of production, and specifically the idea of western patronage. The allusion to silent cinema in Les Saignantes connects to Bekolo's playful and highly stylized approach to filmmaking as well as to the film's broader self-reflexive strategy of foregrounding the cinematic medium. In addition to making reference to film history, the on-screen text comments upon the film's own format as part of the larger transition in filmmaking from celluloid to digital. The text's fluorescent appearance in the diegesis (as in figure 7) clearly evokes the idea of digital production and Les Saignantes' own format, whereas the text in white-on-black is reminiscent of title cards from the silent era and invokes the idea of celluloid. This conscious play with technological formats may also present a critique of a key institution of African cinema, FESPACO, which was the only

\footnotetext{
${ }^{83}$ Gilles Deleuze, Cinema 1: The Movement-Image, trans. Hugh Tomlinson and Barbara Habberjam (Minneapolis: University of Minnesota Press, 2009), 12-13.

${ }^{84}$ Ibid., 13.
} 
film festival of its size that restricted feature length films eligible for the main prize to those made on $35 \mathrm{~mm}$ celluloid at the time Les Saignantes was made. ${ }^{85}$

Bekolo constantly attempts to push forward, confronting previously forbidden subject matter, and destroying old forms and rules by new approaches to style and structure. Les Saignantes' active questioning of genre and experimentation with form signifies an effort to form and transform African filmmaking practices. One moment in particular in the film illustrates this central component of Bekolo's project. In the allegorical reading of the film's narrative events, the SGCC's body symbolizes the body of cinema. The man's physical traits indicate that he is old, a fact that Majolie confirms upon discovering his ID: "Né en 1939? Ah! Mais qu'est-ce qu'un papa comme toi fait avec une Saignante comme moi?"86 The term papa not only highlights the man's advanced age, it also reflects an important step in French film history, one that applies to Bekolo's narrative and aesthetic project within African cinema. In François Truffaut's 1954 essay, "Une certaine tendance du cinéma français," he calls for a new style of cinema free from the old-fashioned ways of the cinéma de papa, an expression that characterizes Truffaut's disdain of the narrative and aesthetic tedium of his cinematic precursors. ${ }^{87}$ Following the publication of Truffaut's essay, French New Wave directors began to experiment with nontraditional narrative forms and editing techniques. Bekolo similarly positions Les Saignantes within a tradition of transgressing the narrative and aesthetic boundaries of the "papas" of African cinema, a necessary shift in order for African cinema to move forward.

\footnotetext{
85 "The conflicts around the transformation of analogue to digital formats came to a head at FESPACO 2013, when several films selected for the official competition were suddenly disqualified because the organizing committee discovered they were not on 35mm celluloid film," Lindiwe Dovey writes. For more on FESPACO's relatively slow and late shift to digital, see Lindiwe Dovey, Curating Africa in the Age of Film Festivals (New York: Palgrave Macmillan, 2015), 105. Dovey discusses contemporary filmmakers' disillusionment with various aspects of FESPACO, and notably Mahamat-Saleh Haroun's emphatic statement in 2012 to never again return to the festival; see pages 104-9.

86 "Born in 1939? Ah! But what is an old man like you doing with a Saignante like me?"

${ }^{87}$ François Truffaut, "Une certaine tendance du cinéma français," Cahiers du Cinéma 31 (January 1954), 15-29.
} 


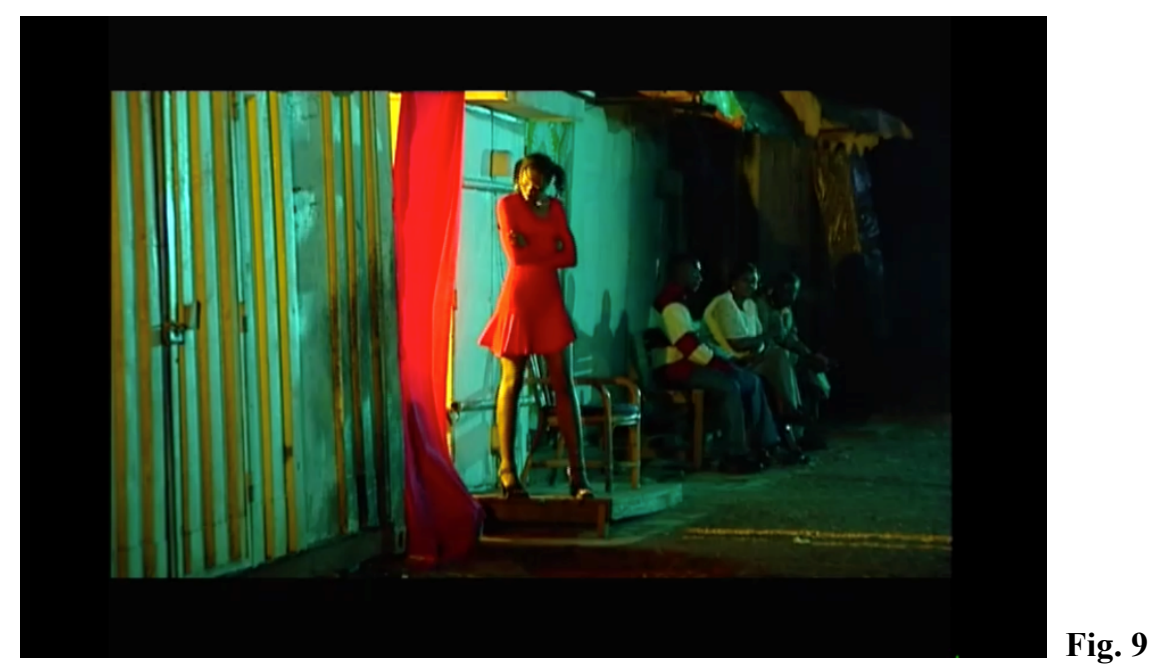

Les Saignantes exemplifies a new political film language by denouncing contemporary socio-political matters and demonstrating the role of cinema in the reinvention of reality. The use of the Mevoungou-a rite réparateur-as a dynamic force that inhabits the main characters and drives them to action allows for an innovative and unusual point of comparison for the cinema. Through the allegory of cinema and the numerous self-reflexive devices that draw our attention to the film as an artificial construction, Les Saignantes posits cinema, one that provokes thought and leads to action, as the ultimate rite réparateur. An image at the end of the film equates the Mevoungou with the realm of films (figure 9). The vivid colors in the frame are consistent with the film's highly saturated color scheme, designed to draw attention to the film as artifice. The narrator states in voice-over, "Mevoungou rêvait en images," while the English translation in the subtitles crystallizes the link to the cinema: "Mevoungou dreamed in Technicolor." Dreaming, or re-imagining the future of (Cameroonian) society, and African filmmaking, occurs through reinvention. For Bekolo, Africa as it stands is not finished, or cooked, as it were, but is in a state of becoming. He does not wish to freeze that reality, but works to continue the process of transforming it through cinema. 
Similar to Les Saignantes, Juju Factory actively questions forms of oppression, and demonstrates cinema's power to subvert and transform through its narrative and aesthetic strategy. In their articulation of a new political film language, Bekolo and Bakupa-Kanyinda's films intervene in their respective situations of dominance, inscribe their films in that reality, and imagine an alternative to that reality through cinema. Whereas Les Saignantes targets the sociopolitical system, Juju Factory denounces forms of artistic repression specifically in the context of African filmmaking.

\section{Screening the Text in Juju Factory: Creation and Resistance}

Juju Factory highlights its own processes of creation. It reveals the story as it ostensibly transpires as opposed to following the narrative conventions of classical realism (or mimesis), which, "pretends that stories pre-exist their telling," writes Robert Stam. ${ }^{88}$ Moreover, it reveals various phases of the creative process that are involved in filmmaking through its primary narrative and aesthetic strategy of screening the text. By text, I refer primarily to the written text, the book manuscript that the protagonist is writing over the course of the film. However, text also refers to the film, as the narrative events of the film comprise the narrative events of the book and in this respect, the book acts as a mise-en-abime. "Screening the text" appears in the title of T. Jefferson Kline's book on intertextuality in French new wave cinema, which explores the new wave's obsession with the literary tradition that it claimed to reject. ${ }^{89} \mathrm{By}$ "screening the text," Kline refers to directors' techniques of screening a literary or cultural reference, a practice that was "conscious and often unconscious. ${ }^{900}$ Kline's use of the term screen includes the notion

\footnotetext{
${ }^{88}$ Stam, Reflexivity in Film and Literature, 138.

${ }^{89}$ T. Jefferson Kline, Screening the Text: Intertextuality in New Wave French Cinema (Baltimore: Johns Hopkins University Press, 1992).

${ }^{90}$ Kline, Screening the Text, 4.
} 
of presenting something in a film (on a screen), and it is this sense that applies to the strategy in Juju Factory. In Juju Factory, screening the text characterizes the film's strategy of deliberately drawing the viewer's attention to the formation, and presence, of the written text. Through thematic and formal devices, it renders explicit the process of creating the book manuscript, and, by extension, the film. Through this central strategy, Juju Factory foregrounds the ability to claim one's story despite forms of artistic repression that attempt to interfere with its creation. The film thereby carries out an act of resistance. In its engagement with the issues that artists, specifically African filmmakers, face, and demonstration of how to overcome those issues through cinema, Juju Factory exemplifies a new political film language.

Indeed, beyond highlighting its own processes of creation, Juju Factory foregrounds the evolution of the creative process in order to subvert authoritative discourse. In the context of the film's narrative, the steady attention to textual creation illustrates the protagonist's ability to overcome the publishing editor's attempts to steer and control the creative direction of the manuscript. Here, the act of writing is not one of mere transcription, but one that creates amidst and undermines the restrictive limitations that attempt to shape it. The editor's constraints implicate the politics of representation in the broader context of African filmmaking. Juju Factory reflects on its context, and links the act of writing, and filmmaking, to power.

As a film that revolves around writing and concern with its own textuality, Juju Factory's strategy resonates with French New Wave directors' metaphor of écriture. The trope of film writing, heralded by Alexandre Astruc's concept of the caméra-stylo, rather vastly encompasses the proliferation of writing-related imagery in New Wave films, as well as the beginnings of many New Wave directors as writer-critics. ${ }^{91}$ As this section elucidates, writing imagery in Juju Factory is part of its larger project of screening the text. Further, Bakupa-Kanyinda also

${ }^{91}$ Alexandre Astruc, "Du stylo à la caméra et de la caméra au stylo," L'Écran français 144 (March 30, 1948). 
publishes written works in addition to making films; in fact, prior to going to film school, he attended university in Belgium and wrote a thesis on the problematic representation of Africa and Africans in Belgian imagery, which was published as a collective volume. ${ }^{92} \mathrm{He}$ is not a writer-critic in the same sense as the New Wave directors, but even this slight comparison allows for greater appreciation of his film's strategy as a form of written criticism. Like Bekolo, Bakupa-Kanyinda is an artist-intellectual who sees filmmaking as a potent form of activism. Along with its unique and innovative style, his film's ardent stance against forms of domination in artistic creation demonstrates his effort to transform African filmmaking practices from both artistic and infrastructural standpoints.

By screening the written text within the film's frame, Juju Factory “puts on stage several levels of representation-one embedded in the other," as Manthia Diawara writes. ${ }^{93}$ Recurring techniques compel the viewer to apprehend multiple layers or realities at once; among these techniques, which contribute to the film's multi-layered visual economy, are frequent superimpositions and dissolves. The film's use of voice-over adds an additional layer by featuring the writer-protagonist reading passages of his manuscript. Along with the film's attention to the theme of exile, these formal strategies align Juju Factory with Laura Marks' category of intercultural cinema, by which she defines films that are inflected by two or more cultural regimes of knowledge. ${ }^{94}$ According to Marks, intercultural works put on stage multiple levels of representation at once, use experimental means to arouse memory, and reflect the setbacks that block their production. Juju Factory's impulse to push borders by denouncing forms of artistic repression further relates it to intercultural cinema's preoccupation with

\footnotetext{
${ }^{92}$ ZAIRE 1885-1985: cent ans de regards belges (Bruxelles: Coopération par l'Éducation et la Culture (C.E.C.), 1985).

${ }^{93}$ Diawara, African Film, 133-34.

${ }^{94}$ Marks, The Skin of the Film, 24.
} 
"questioning the political and cultural limits of what can be represented." $" 95$ Although he overlooks the film's relation to intercultural cinema, Diawara situates Bakupa-Kanyinda alongside other African diaspora directors by noting the influence of John Akomfrah and others specifically during the film's opening sequence. ${ }^{96}$ In his overview of the film's innovative narrative and aesthetic strategies, which leads him to remark that it is "stylistically, one of the most interesting African films," Diawara highlights the frequent use of close up and point-ofview shots as part of the film's investment in characterization. ${ }^{97}$ As opposed to serving "sociological or political purposes," Diawara states that this interest in character psychology, solely "for the purpose of telling a well-made story," is an aspect that distinguishes Juju Factory from the majority of African films. ${ }^{98}$ Even though the film demonstrates keen interest in character development, as Diawara observes, further exploration of these types of shots in relation to the film's larger project brings out its formal attentiveness to artistic creation and resistance. Additionally, my discussion of Juju Factory builds upon Diawara's observations that the film puts on stage several levels of representation, and that the politics of representation are one of its main subjects.

\footnotetext{
95 Marks, The Skin of the Film, 12.

${ }^{96}$ Diawara's reading of the opening sequence focuses on the superimposed images as references, or "salutes," to films by African diaspora directors, including John Akomfrah's Handsworth Songs (1987), Haile Gerima's Sankofa (1993), Raoul Peck's Lumumba (2000), and Spike Lee's Malcom X (2010). African Film, 132-33. Interestingly, Marks discusses all of these films in The Skin of the Film with the exception of Lee's.

${ }^{97}$ Diawara, African Film, 133.

${ }^{98}$ Ibid., 135. Diawara posits that interest in character psychology is one of the distinctive features of the new wave of African filmmaking, which, he notes, diverges from "Sembenian caricatures that serve as mouthpieces of the director" (ibid.). Diawara's reading of the close up shot contrasts with the use of the device in Third World films where it serves "more of an informational purpose than as a study in "psychological realism," according to Teshome Gabriel. Gabriel, "Towards a Critical Theory of Third World Films," in Cinemas of the Black Diaspora: Diversity, Dependence, and Oppositionality, ed. Michael T. Martin (Detroit: Wayne State University Press, 1995), 84.
} 
Juju Factory is set in Matongé, a district of Brussels that is considered the second capital of the Democratic Republic of the Congo. ${ }^{99}$ The film follows the story of Kongo Congo, a writer who is at odds with his editor regarding the form and content of his book manuscript.

The narrative that he brings to fruition straddles fiction and reality, and draws inspiration from the historic events and people that have shaped Matongé, the individual and collective experiences of life in exile, and the everyday lives of the people around him. His editor, on the other hand, attempts to steer the creative direction of Kongo's book project, wanting a kind of "traveler's tale spiced with ethnic ingredients." 100 He openly reminds Kongo that he holds the money and, therefore, the power. Despite their contract, Kongo ultimately refuses to conform to the editor's orders, and writes his story that, in the end, bears the title Juju Factory. While the film explores the process of artistic creation and its setbacks, it also explores traces of Congolese history in contemporary Brussels, especially that pertain to the fallen hero of Congolese independence, Patrice Lumumba.

From the outset, Juju Factory screens the text through various audio-visual means in order to highlight its evolution. Even before the viewer first sees Kongo, she hears the clicking of keys on a keyboard, a sound that draws attention to the text and its creation. The first moment in which Kongo appears, the camera frames him in an over-the-shoulder shot, focusing on the screen of his computer (see figure 10). The initial title of his manuscript, "Matongé Village," appears at the top of an otherwise blank Microsoft Word document; Kongo is beginning the writing process. The blank page establishes that the story of the film is concurrent with the development of the written text, as this occurs at the start of the film. In addition to drawing the viewer's attention to the text, the shot also evokes the layers of consciousness that go into the

\footnotetext{
99 Diawara, African Film, 133. Matongé is unique in being an area in a European city that bears an African name. 100 Ibid.
} 
creation of art. First, the document is a blank slate upon which Kongo's ideas will take shape.

Additionally, the camera's proximity to his head and its position in the foreground alludes to the realm of imagination and ideas, which is where a work of art first begins to form.

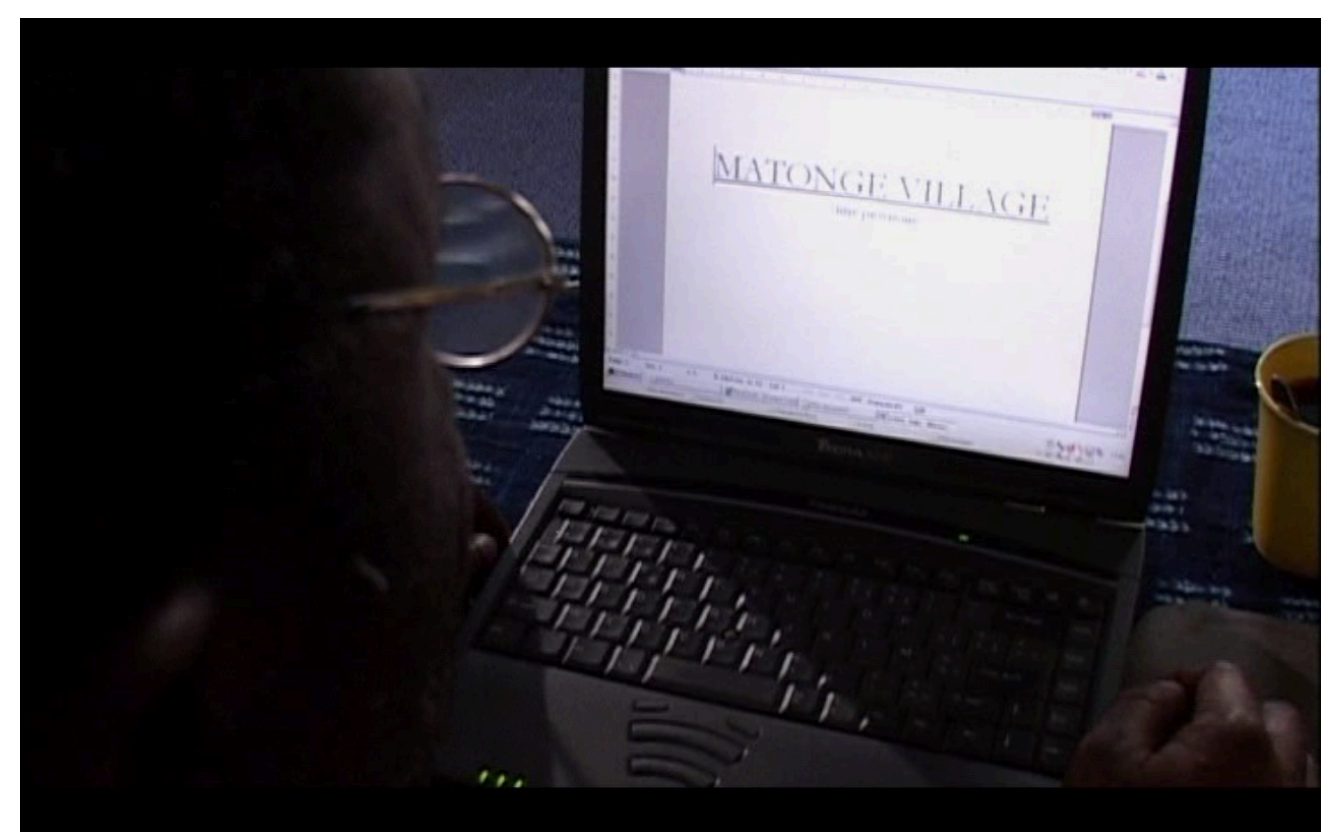

Fig. 10

While Juju Factory focuses somewhat broadly on the process of artistic creation, it specifically draws attention to phases of filmmaking. Indeed, film creation begins with a written text-the script, which eventually becomes image and narrative. The film's frequent use of superimposition, often layering words over image, depicts these initial phases. In one example, the camera frames Kongo in front of his computer with the superimposed image of a passage of his manuscript (figure 11). This technique visualizes the progression from idea to written form or script, and from script to image, and literally demonstrates the notion of screenwriting. The dialogue even refers to this technique at one point in the film, when Muadi, Kongo's sister-inlaw, describes Kongo’s approach to writing to another character by saying, "Quand il a l'inspiration, on voit des mots qui courent sur son front."101

101 "When he is feeling inspired, you can see the words running across his forehead." 


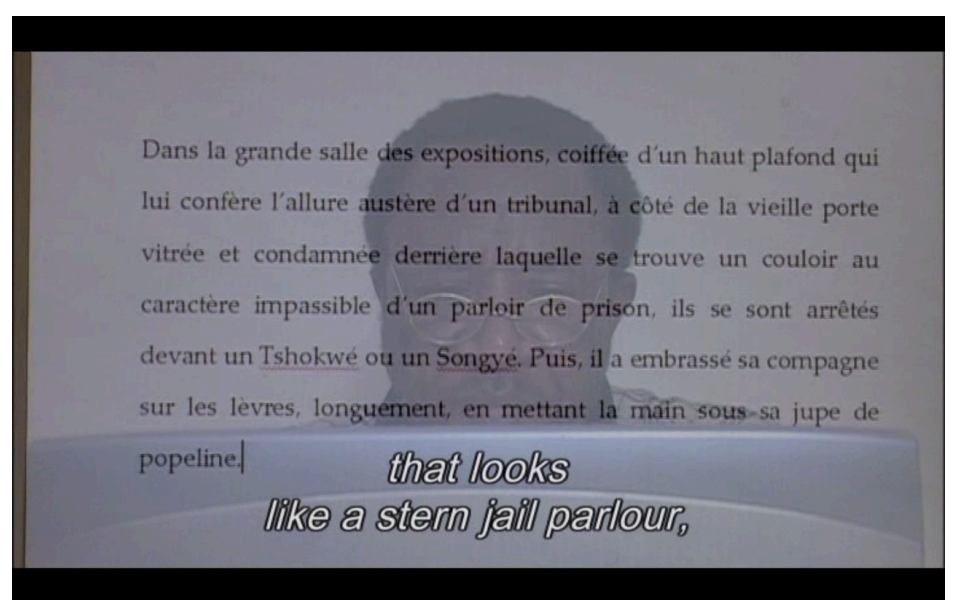

In addition to layering image and text to illustrate the notion of screenwriting, shot composition also explicitly evokes the process of film creation. For instance, the camera frames one of the lenses of Kongo's glasses in extreme close up, which reflects the images of his fingers typing (figure 12). Panning from left to right, the shot focuses on his second lens, echoing the reflected image of his hands moving across the keyboard. The rim of his glasses creates a frame within the frame of the film, which self-reflexively calls our attention to the film and its layering of written text and image. The various gazes in this shot-the viewer upon Kongo, Kongo looking at his hands-emphasize the act of perception that is involved in both creating and viewing a film, and more broadly a work of art. This technique visualizes Kongo's layers of consciousness, by evoking the instant at which the idea is shaped into form through the typing of his fingers. In a later shot, the camera shifts this image by framing the reflection of the manuscript on the computer screen in the lenses of Kongo's glasses (figure 13). The sequence depicts the transformation of text into visual narrative. While Kongo's deep voice narrates in voice-over, the shot (in figure 13) alternates with images that enact the passage in question, about the ghost of Lumumba who wanders the nocturnal streets of Brussels. Using subjective camera, the sequence proceeds from the standpoint of shaky and unstable camera movements as it slowly meanders along an empty sidewalk. 

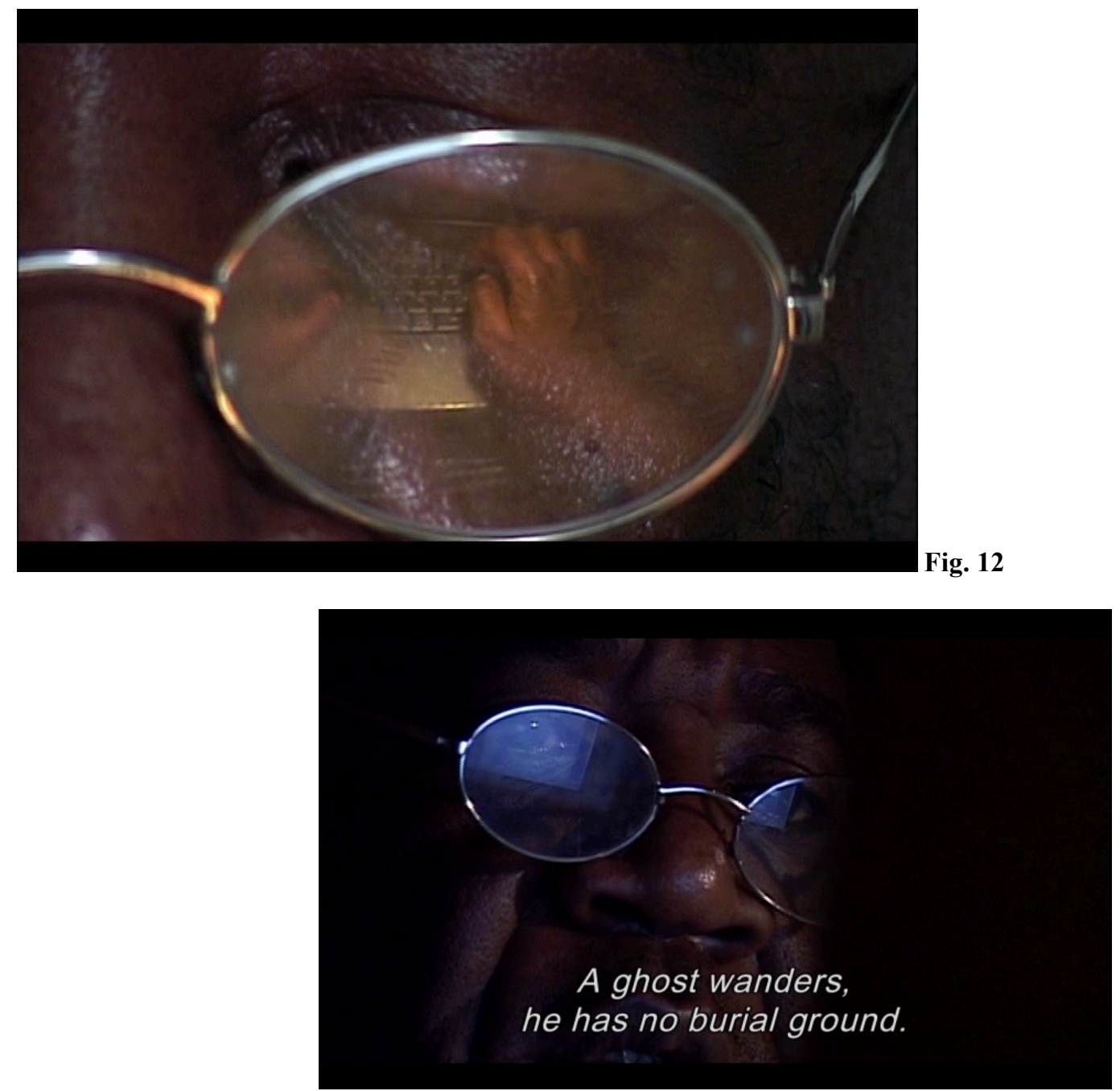

Fig. 13

By depicting the transformation of text or script into image and narrative, Juju Factory also aims to recover cultural memories that have been buried or repressed. The most salient cultural memory that Juju Factory engages with is the figure of Patrice Lumumba, his unfinished project and the inability to bury his corpse, which casts a spectral shadow on the present. As the hero of Congolese independence, Lumumba represents freedom, and his presence in Kongo's book/the film signifies a desire for freedom in artistic creation. Recurring over the course of the film, a photograph of Lumumba is superimposed over the image in the frame, indicating both the idea of freedom in expression, for which Kongo strives, and that his ghost is everywhere. "Brussels was built on the wealth of the Congo and Lumumba's blood is on every monument, 
including the church standing at the entrance of Matongé," Diawara observes. ${ }^{102}$ The poignant passage of Kongo's manuscript about the wandering ghost of Lumumba discusses the subject's suffering due to the loss of his leader and, as a result, his cultural identity. As Kongo narrates this passage, the viewer is pulled into the film through the use of subjective camera. This technique, which is distinct from those of the rest of the film, compels the spectator to engage with history and memory on an embodied level. According to Teshome Gabriel, this "sharing of responsibility in the construction of a text, where both the filmmaker and the spectator play a double role as performers and creators," is a characteristic of Third Cinema, although as Laura Marks points out, it is simply more explicit, and more motivated, in certain types of films, notably intercultural works. ${ }^{103}$ By focusing on Lumumba's death and legacy, this example in Juju Factory suggests that experimental-and perhaps, more personal-modes of representation allow for the recovery of cultural memories.

It is precisely the book's engagement with certain aspects of history and its innovative aesthetic strategies that Kongo's editor wishes to stifle. On the one hand, this illustrates the editor's unresponsiveness to history and memory. Also a Congolese expatriate, Joseph Désiré is divorced from his native culture and history, and firmly proclaims his adopted national identity: “Je suis pas congolais, je suis belge." ${ }^{\prime 104}$ His only tie to his native Congo is a certificate issued by the Société des Pétroles au Congo, which associates him with the extraction of natural resources, and thus potentially removing wealth from the country. ${ }^{105}$ An assimilated (or acculturated)

\footnotetext{
102 Diawara, African Film, 136.

${ }^{103}$ Marks, The Skin of the Film, 62. She is referring to Teshome Gabriel's idea that in the "Third World context" there is an "understanding between the viewer and the performers $[\ldots]$ that their positions are interchangeable without notice." Gabriel, "Towards a Critical Theory of Third World Films," 81.

104 "I am not Congolese, I am Belgian."

${ }^{105}$ In the year prior to the film's release, 2005, the Sociéte Nationale des Pétroles au Congo was exposed for taking wealth without putting it back into the country, to the detriment of the population. "Congo Oil Trading Scandal
} 
individual, Désiré embodies the first phase of cultural evolution of Fanon's threefold path to liberation, a model he puts forth in Les damnés de la terre. ${ }^{106}$ This aspect of his identity inflects his reactions to Kongo's ideas. For instance, when he rejects a particular passage of the manuscript, he emphatically denies any sense of shared cultural values: "Vos ancêtres et votre Lumumba, enterrez-les où vous voulez, mais pas dans ce livre que je finance!"107 Other characters qualify Désiré as an "N.G.M.," or a "nègre génétiquement modifié," due to his "contradictory form of assimilation that unites an essentialist, idealized form of Africanness to an exoticist approach to multiculturalism." ${ }^{108}$ For this reason, Manuela Sanches likens him to Senghor. ${ }^{109}$ In fact, his name concretely associates him with another postcolonial African leader; indeed, Joseph Désiré is the birth name of Mobutu Sese Seko. Through this subtle allusion to the ex-Zairian autocrat, Désiré's domineering attitude and oppressive treatment of his clients may represent, on a larger scale, state authority figures or governments who stand in the way of artistic production, such as through censorship.

In addition to his denial of many aspects of Congolese history and culture, Joseph Désiré embodies the worst of commissioning agents. His lofty, self-important airs are encapsulated by a large, framed photograph of himself dressed in a suit that sits prominently on the windowsill behind his desk. A picture frame in a window frame within the film's frame, the photograph selfreflexively calls attention to the film and to his arrogant demeanor therein. Désiré rejects the first

Implicates Top Government Officials," Global Witness, December 13, 2005, https://www.globalwitness.org/archive /congo-oil-trading-scandal-implicates-top-government-officials/.

106 The three distinct phases of cultural evolution among the colonized during and after the colonial era that Fanon sketches out are: (1) assimilationist (identifying with the occupying power), (2) cultural nationalist (resisting attempts to assimilate), and (3) nationalist (revolutionizing the literature of the colonized). Frantz Fanon, Les damnés de la terre, 3rd ed. (Paris: Gallimard, 1991), 178-79.

107 "And you can bury your ancestors and your Lumumba where you like, but not in the book that I am paying for!" (original emphasis).

${ }_{108}$ Manuela Ribeiro Sanches, “African Screens (Re)Viewed from Lisbon,” Nka: Journal of Contemporary African Art 27 (Fall 2010), 60.

${ }^{109}$ Ibid. 
two writers who enter his office, asking arrogantly, "Savez-vous devant qui vous êtes?"110 Importantly, one of the writers is played by Bakupa-Kanyinda. This allusion to his authorial function, and also a nod to Hitchcock and his trademark appearances, leads one to wonder to what extent Juju Factory advertises its own circumstances of production. Indeed, Désiré's selfaggrandizement and his attempts to steer the creative direction of Kongo's project imply an acerbic critique of film producers who subject artists to their "aesthetic whims and financial manipulations," in the words of Robert Stam. ${ }^{111}$ Even before Désiré and Kongo first meet, an exterior shot of the editor's office evokes the subordination that will characterize his treatment of Kongo. Kongo approaches the office building and the next shot cuts to his point of view; first facing towards the ground, the camera brusquely tilts upward to behold the building in an extreme low angle shot. From this angle, the imposing structure appears to tower over him (figure 14). ${ }^{112}$ In this shot, the building also looks like an open book, a visual reminder of what is at the heart of Kongo's tense relationship with his editor.

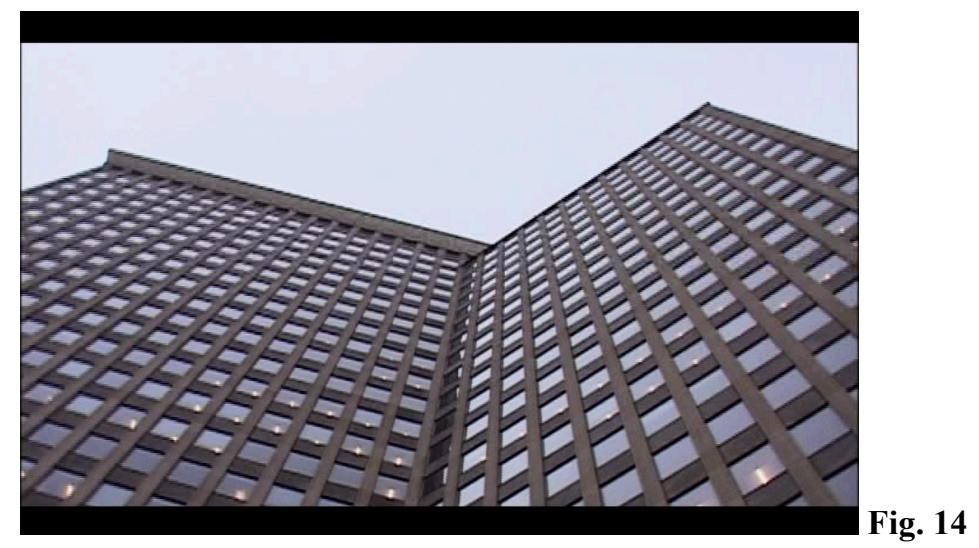

\footnotetext{
110 "Are you aware whose presence you are in?"

${ }^{111}$ Stam, Reflexivity in Film and Literature, 100. Désiré's arrogance and constant intrusion into Kongo's project echo the character of the Hollywood film producer in Jean-Luc Godard's Le Mépris (1963). Through this figure, Jeremiah Prokosch, Godard presents his distaste of film producers and a broader critique of international coproductions in European cinema at the time.

112 This image is remarkably similar to a shot in Ousmane Sembène's La Noire de... (1966), which depicts the protagonist's first view of the apartment building in Antibes where she is to work as a maid, but ultimately is treated as a slave.
} 
Juju Factory implicates the politics of representation by highlighting the editor's consistent attempts to steer the creative direction of Kongo's book. His vision of the manuscript promotes an exotic representation of Africa and reflects a specific period of African cinema. Désiré targets Europeans, or Westerners, as potential readers, when he repeats emphatically, "Les mots et les images doivent rester neutres et beaux." ${ }^{, 113}$ Travel guides and chronicles, such as Le Guide du Routard, Lonely Planet, and National Geographic are among the examples he cites to illustrate his aspirations for the manuscript as "une sorte d'invitation au voyage." ${ }^{114} \mathrm{His}$ insistence upon imagery that is "picturesque," and on the exclusion of potentially unflattering, polemical aspects of history, culture, and politics, evoke a narrative and aesthetic approach in certain films from the 1980s and 1990s. In African Cinema: Politics and Culture, Manthia Diawara categorized films such as Yeelen (Souleymane Cissé, 1987) and Tilaï (Idrissa Ouedraogo, 1990) as "return to the source." 115 This tendency refers "to the way they spun mythical dimensions of the African past and oral storytelling forms into new cinematic tales," Lindiwe Dovey writes. ${ }^{116}$ These and other films, including Wend Kuuni (Gaston Kaboré, 1982), Yaaba (Idrissa Ouedraogo, 1989), and Guimba (Cheick Omar Sissoko, 1995) have commonly been labeled as "calabash cinema." 117 Critics, including Clyde Taylor and Férid Boughedir, and filmmakers, namely Haile Gerima and Jean-Pierre Bekolo are critical of the tendency. ${ }^{118}$ They believe that the portrayals of an ahistoric or precolonial, rural (often geographically non-specific) setting, and a society and/or activities that are untouched by modernism, pander to "Western

\footnotetext{
113 "The words and images should be neutral and beautiful." (Emphasis in original.)

114 The manuscript should be "an invitation to travel." This phrase evokes the title of Charles Baudelaire's poem, "L'invitation au voyage."

${ }^{115}$ Manthia Diawara, African Cinema: Politics and Culture (Bloomington: Indiana University Press, 1992), 159-64.

${ }^{116}$ Lindiwe Dovey, Curating Africa in the Age of Film Festivals (New York: Palgrave Macmillan, 2015), 52.

${ }^{117}$ Diawara employs the term "calabash cinema" in African Film, 96. However, to my knowledge, the term originates from Jean-Pierre Bekolo's Aristotle's Plot, when the gang leader, Cinema, uses it during the movie theater sequence in which the gang mocks the film playing that illustrates Bekolo's version of the tendency.

118 Thackway, Africa Shoots Back, 40.
} 
desires for images of Africa that are colourful, exotic, distanced from the unhappy contemporary condition of the continent, and generally in line with Eurocentric stereotypes."119 They believe that such films were made with the intention to facilitate reception for European or Western audiences; for instance, Boughedir classifies Yeelen as "escapist Africa offering a journey for the European spectator." ${ }^{\prime 20}$ Not all scholars and filmmakers share this view, and more recent scholarship "has reassessed the value of these films, arguing that, in many cases, they use the past to disguise political critique of the present, thereby avoiding the possibility of censorship in their countries of origin." ${ }^{21}$ Nevertheless, in Juju Factory, the editor's characterization of the product he desires as an exotic travel tale strongly echoes Boughedir's idea. The vision Désiré promotes is one that, he believes, conforms to the potential reader's desires: 'Je sais ce que le lecteur attend," he tells Kongo again and again. ${ }^{122}$ Désiré's attempts to control the manuscript by emphasizing his financial support indicate that only by meeting certain aesthetic criteria will it receive funding.

Juju Factory raises the idea that institutions may impose certain criteria in allocating subsidies to artists, and it simultaneously underscores its mode of production outside of these funding sources. It is the vice president of a Belgium-based non-profit association, Aid to Africa, who appoints Désiré as publishing editor. Thus, the film implies that some European institutions that subsidize artists, especially those that purport to develop African countries, may impose

119 Murphy and Williams, Postcolonial African Cinema, 10.

120 Thackway, Africa Shoots Back, 40. As both Yeelen and Tilaï were awarded prizes at Cannes in the late 1980s and early 1990s, the concerns I mention here echo what Lindiwe Dovey refers to as "broader global anxieties about the consecration of non-Euro-American films at festivals and the possible 'Orientalism' and exoticism in which these films were compelled to participate to gain such recognition.” Dovey, Curating Africa, 52.

${ }^{121}$ Dovey, Curating Africa, 52. She cites studies by Ralph Austen (2007) and Kate Bolgar Smith (2010) as examples. In Diawara's section in African Cinema devoted to the 'return to the source' category, he observes that filmmakers turned toward the strategy in order to distance themselves from a didactic approach, avoid censorship, attempt to locate solutions to contemporary issues within precolonial traditions, and search for a new film language. Diawara, African Cinema, 160.

122 "I know what the reader expects." 
their own artistic values. Roy Armes' study on French aid to African filmmaking affirms that, in order to achieve funding, an African film "needs to satisfy a number of divergent foreign needs and interests. It must conform partly at least to European criteria as to what constitutes an 'African' film."' 123 The film's setting in the filmmaker's home country is one of the requirements to be eligible for French funds. ${ }^{124}$ Diawara observes that the setting requirement may give rise to a "schizophrenic situation" in which the African director, born and educated in an urban environment, "is told to represent an Africa that is only 'real' in the deepest fantasies of the European producer." ${ }^{\prime 25}$ According to Bakupa-Kanyinda in an interview from 2006, this criterion persists:

un film réalisé par un Africain dans un décor européen n’est éligible à aucun financement européen. On finance l'Africain pour qu'il filme la misère de chez lui, les histoires de son village, son puit d'eau, tiens! (sic) Parce que les services de coopération disent que c'est pour le 'développement de là-bas.' 126

Many features of Juju Factory, including its setting in a European city and its engagement with the politics of representation, indicate that it did not receive institutional support of the type that imposes narrative or aesthetic requirements. Indeed, it "was made outside the usual institution of productions of French aid to African cinema." ${ }^{127}$ Like Kongo’s resistance to adopt a tone and

${ }^{123}$ Roy Armes, African Filmmaking North and South of the Sahara (Bloomington: Indiana University Press, 2006), 57. Armes' brief discussion covers the period from 1980-2004. Claire Andrade-Watkins' study focuses on the two decades prior. See Andrade-Watkins, "France's Bureau of Cinema-Financial and Technical Assistance, 1961-1977: Operations and Implications for African Cinema," in African Experiences of Cinema, ed. Imruh Bakari and Mbye B. Cham (London: British Film Institute, 1996): 112-27.

${ }^{124}$ Armes, Dictionary of African Filmmakers (Bloomington: Indiana University Press, 2008), 7.

125 Diawara, African Film, 35.

${ }^{126}$ Barlet, "Le Développement est une diplomatie qui n'a rien à voir avec la qualité." "A film directed by an African in a European setting is not eligible for European financing. Africans are funded for filming the misery in his home country, the stories from his village, his well of water, how about that! Because the Foreign Ministry says that its aim is to support development over there." (My translation)

${ }^{127}$ Diawara, African Film, 136. Juju Factory was co-produced by Akangbe Productions (France) and Diapanda Yo! (Democratic Republic of the Congo). 
style that are "neutral" and "beautiful," as the editor stipulates, the film "does not make an anthropological or exotic compromise for the Western spectator." ${ }^{128}$ Beyond these features, the film's strategy of screening the text demonstrates the ability to overcome forms of artistic repression by those who represent financial institutions.

Juju Factory highlights that the intrusion of commissioning agents is concurrent with the process of artistic creation. Beyond dictating the form and content of Kongo's manuscript, the editor intervenes in the writing process, an action the film illustrates through the techniques of crosscutting and direct-address. The alternation of shots and abrupt cuts indicate a minimal time lapse in order to highlight Désiré's interference, indicating that as soon as words are written, he rejects them. For example, one sequence that exemplifies the editor's interference begins with Kongo writing a passage that makes implicit reference to Mobutu. Consistent with the film's strategy of screening the text, it brings our attention to the passage in multiple ways, from framing the text on the screen of Kongo's computer, to playing Kongo's voice reading in voiceover, to superimposing images that depict the written passage over the image of Kongo typing. A cut redirects the viewer's attention to Désiré, framed in a medium shot at his desk with the pages of the manuscript in front of him. His comments reveal that he has just read the very passage Kongo is writing. Looking at the camera, he states: "Comment peut-il oser écrire de conneries pareilles! Celles-ci par exemple. Jugez par vous-même" (figure 15). ${ }^{129}$ The direct address is highly unusual, and implicates the viewer in Désiré's arrogant dismissal. The camera zooms in on him as he reads an excerpt out loud about the inability to invoke one's ancestors. Irritated, he removes his glasses and again looks at the camera and addresses the viewer: "Franchement,

\footnotetext{
${ }^{128}$ Diawara, African Film, 137.

129 "How dare he to write such nonsense! Take this, for example. Judge for yourself."
} 
dites-moi ce que vous en pensez." ${ }^{130}$ The shot cuts back to Kongo in the thick of the writing process, and then abruptly returns to a close up of the editor, who sneers to the camera: "Voilà le genre."131 Juju Factory deploys crosscutting and direct-address throughout the film to emphasize Désiré's continuous attempts to meddle. In one example, the shot cuts from Kongo writing to Désiré throwing a stack of pages out the window. An exterior shot follows them as they flutter to the ground.

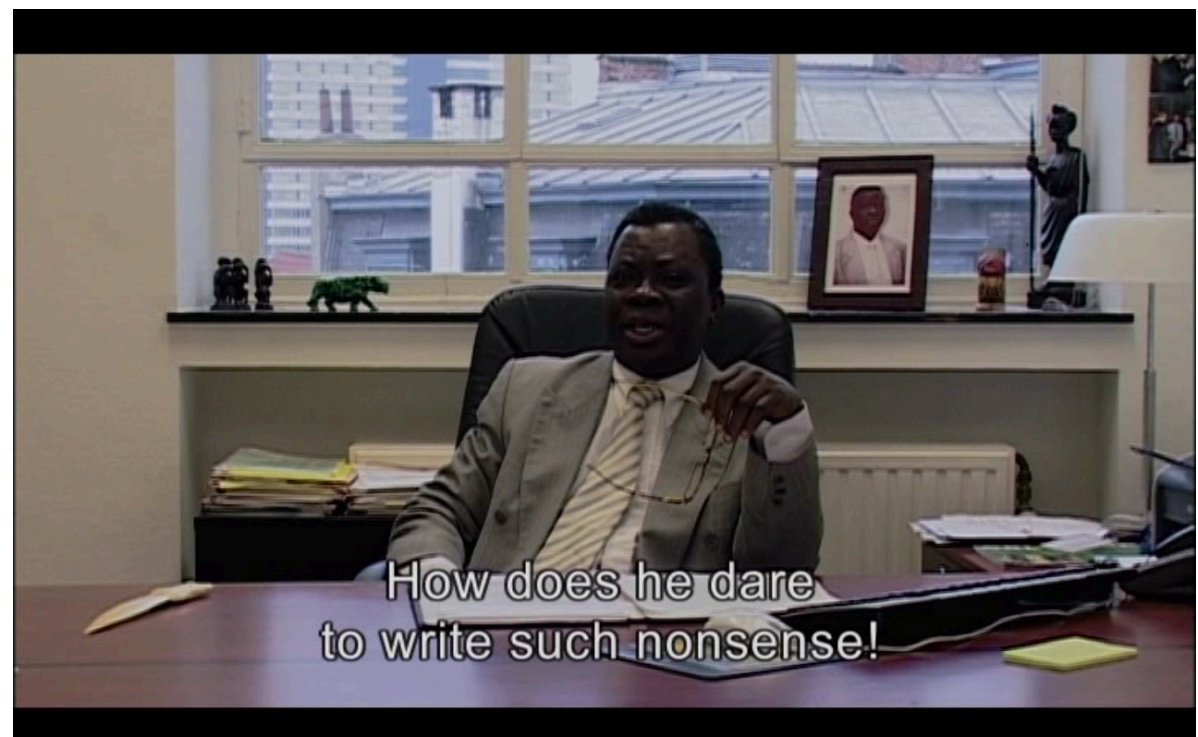

Fig. 15

If the film highlights artistic repression through the editor's efforts to steer and control the creative direction of Kongo's manuscript, it emphasizes above all the ability to overcome it. Through the strategy of screening the text, Juju Factory foregrounds the steady progression of the written document in spite of Désiré's interference. Indeed, the film's continual emphasis on writing signifies Kongo's resistance to relinquish control over his project. He persists in writing his story. At one point, when the editor withholds his advance, Kongo's electricity is cut off, but he continues to write using a pen and paper by candlelight. An over-the-shoulder shot focusing on his hand on the page signals that he assumes control of the situation by taking matters into his

\footnotetext{
130 "Honestly, tell me what you think about that."

131 "See, that's what I mean."
} 
own hands. The moment in which he renames the manuscript signifies that he fully claims control over his story and the creative process. In a shot almost identical to the one near the beginning of the film that reveals the initial title of "Matongé Village," the camera frames the screen of the computer as Kongo types "JUJU FACTORY" (figure 16). The shot lingers on the screen while Kongo types each letter of the new title, which simultaneously erases the old one. To exemplify the completion of this critical gesture, the shot cuts to the new title page coming out of the printer at the editor's office.

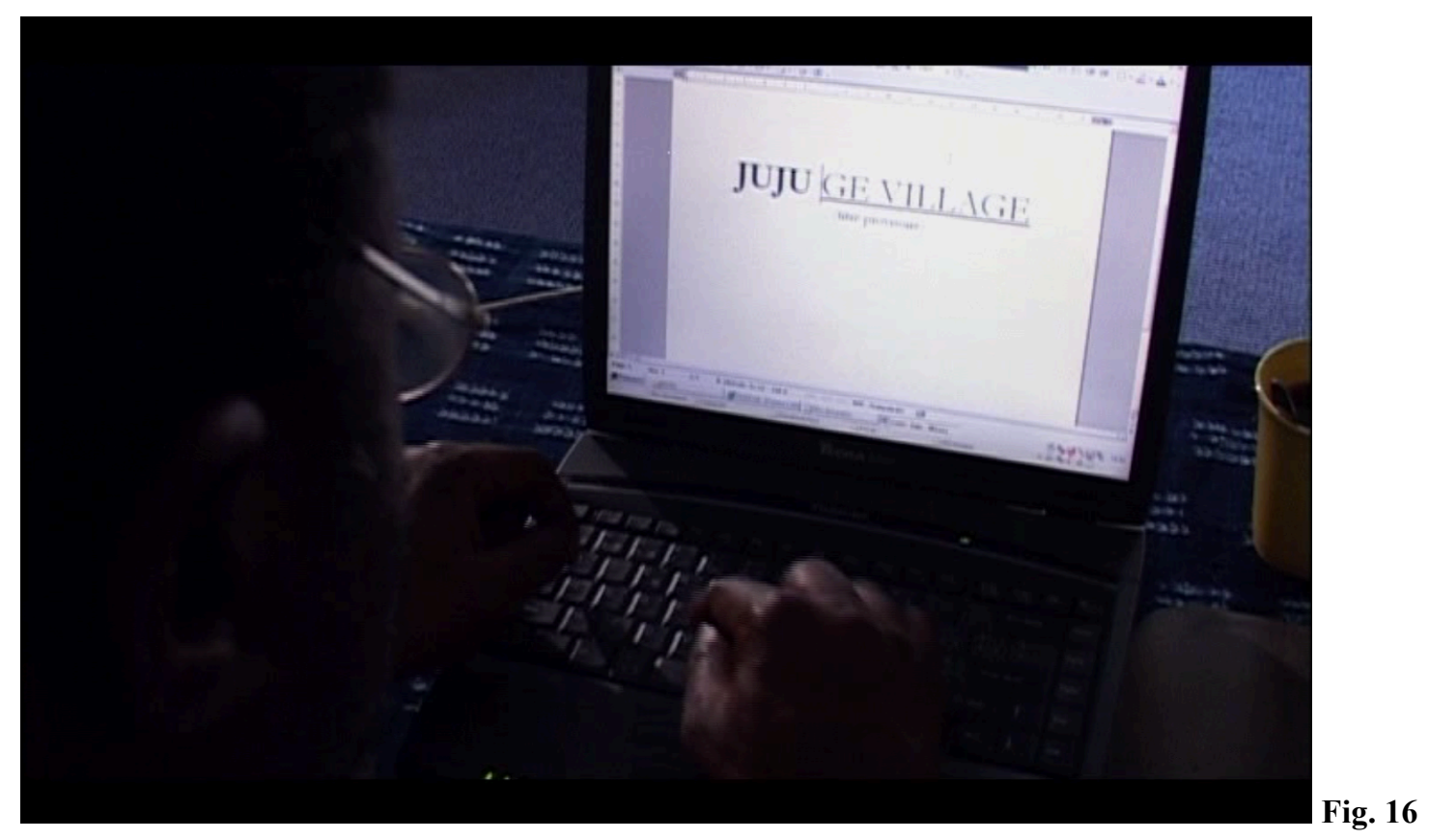

Beyond the fact that the manuscript title is identical to the film's, the film hints that the strategy of screening the text may encode its own mode of production-that is, it may present a mise-en-abime of its own circumstances. When Kongo changes the title to "Juju Factory," he highlights the two words, making them appear more prominently on the page. The camera zooms in on the screen and settles on the first four letters of the second word, spelling "FACT" (figure 17). Through this pronounced gesture, the film suggests that a certain degree of accuracy surrounds the narrative events, especially those pertaining to its central conflict. 


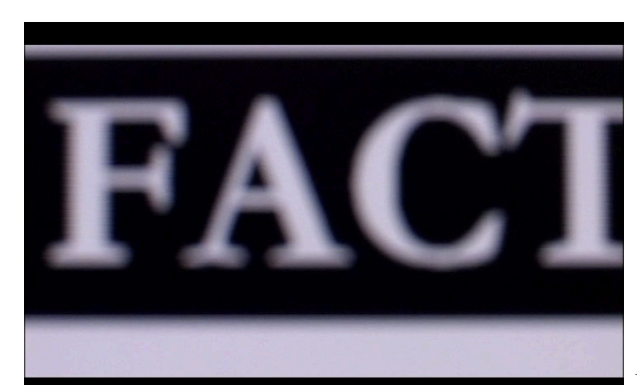

Fig. 17

As on-screen text that refers to the film's circumstances of production, this example recalls Tom Conley's concept of film hieroglyphs. ${ }^{132}$ In contrast to the film's extensive use of superimpositions and its multi-layered visual economy, here the text appears in white lettering against a black background, a technique that renders manifest the screen as a flat surface for transmitting information. This example echoes the use of on-screen text as meta-discourse in Les Saignantes. Indeed, it indicates that the film reflects its context of production, and by communicating this to the viewer, it seeks to incite critical awareness about artistic repression both within the context of African filmmaking and beyond.

When Kongo's book is published at the end of the film, a critic asks him, "Que signifie le juju du titre?"133 Instead of pronouncing the title term according to rules of pronunciation, he pronounces it "joujou." "Joujou" means a child's toy, and this term evokes the idea that African artists (writers, filmmakers, etc.) are playthings, toyed with by commissioning editors/agents, as in the story of the film. This pronunciation also evokes the French verb jouer, meaning to play, especially in the sense of playing a role or acting. The notion of acting out or performance implies repetition, meaning that that which is being acted out is not occurring for the first time. The film thus suggests that the narrative refers to its context of production, and also that artistic

\footnotetext{
132 Conley, Film Hieroglyphs.

133 "What does the juju of the title signify?" "Juju" means an object of any kind superstitiously venerated by West African native peoples, and used as a charm, amulet, or means of protection; a fetish. Oxford English Dictionary, s.v. "juju," accessed July 20, 2015, http://www.oed.com.proxy.its.virginia.edu/view/Entry/101988?result=1\&rskey= zVH2bb\&.
} 
repression is ongoing but, perhaps, so too is resistance. It must also be noted that these various resonances also allude to Bakupa-Kanyinda, who is drawing attention to and denouncing instances of artistic repression in a playful manner.

The primary narrative and aesthetic strategy of screening the text in Juju Factory highlights the processes of artistic creation, writing and filmmaking. By screening the text, the film visualizes the moments at which various steps occur: the transformation of idea into written form, and script into image and narrative. In addition to highlighting the phases of film creation, Juju Factory reflects its context of production. It highlights resistance to artistic repression through Kongo's ability to overcome the conflict with his editor and to write his story. Within the context of African filmmaking, the film denounces financial institutions that seek to shape representations of Africa and Africans.

As the above analyses attempt to illustrate, Juju Factory and Les Saignantes exemplify a new political film language. Bekolo's and Bakupa-Kanyinda's films intervene in their respective situations of dominance, and imagine an alternative to that reality through cinema. This chapter's corpus highlights the diversity of the tendency as Les Saignantes and Juju Factory confront different geopolitical realities, and separate issues within African filmmaking. Beyond these two titles, the mode of filmmaking presented in this chapter is also observable in other works. For example, Abderrahmane Sissako's Bamako (2006), which was released the same year as Juju Factory and one year after Les Saignantes, and Bekolo’s Le Président (2013) illustrate the new political film language in their narrative and aesthetic strategies. They could productively be studied side by side or as additional cases to demonstrate the tendency. However, because their modes of representation are closer to documentary (even if this category could be contested), I did not include them in my study, which I limited to fictional narratives. 
What Les Saignantes and Juju Factory achieve in the fictional realm of the film is clear. But beyond this, to what extent do their political projects translate into work in the real world? Both films have limited distribution, especially Juju Factory, which may restrict the levels of engagement they seek to incite. Bamako and Le Président, on the other hand, have reached their target audiences through different strategies. Bamako was screened within the walls of the World Bank, one of the global institutions that characters in the film identify for its "complicity in the perpetuation of Africa's economic problems," as Alison Levine writes. ${ }^{134}$ Le Président aims to raise questions and incite critical awareness among African populations about long-standing periods of single-party rule in African countries and in Cameroon in particular, an objective that finds expression in the film's subtitle, Comment sait-on qu'il est temps de partir? ${ }^{135}$ Banned in Cameroon, Le Président screened online on BuniTV, a Kenya-based Video-On-Demand (VOD) platform, and "attracted 8,500 online views in the one week it was made available, which equates to about 42 cinema screenings, and the audience feedback was extremely positive." ${ }^{\prime 136}$ Despite having more limited viewings, Juju Factory and Les Saignantes directly address spectators and prompt them to consider the issues they raise. At the very end of Les Saignantes, a final written phrase punctuates the film and challenges, even pleads, spectators to continue the process of reinvention by taking the next action on their own: "Comment regarder un film comme ça et ne rien faire par la suite?"137 African films that raise questions specifically regarding the current state of African cinema, such as in the areas of distribution and spectatorship, is the focus of my next chapter.

\footnotetext{
134 Alison J. Murray Levine, “Words on Trial: Oral Performance in Abderrahmane Sissako's Bamako," Studies in French Cinema 12, no. 2 (2012), 164. Levine's discussion includes an exploration of the performative role of the film in the world.

135 "How do you know when it's time to go?"

136 Dovey, Curating Africa, 82.

137 "How can you see a film like this and do nothing?"
} 


\section{Chapter Three}

\section{Questioning African Cinema: Performativity in Bye Bye Africa and Lieux Saints}

A wide shot in black and white frames the viewing area of an open-air cinema. The seats are empty and the room is silent. The shot lingers on the blank projection screen as the operator of the hand-held camera slowly backs away. This image comes from Mahamat-Saleh Haroun's Bye Bye Africa (1999), during the main character's investigation of the state of cinema in Chad. ${ }^{1}$ In Lieux Saints (Sacred Places, 2009), a film directed by Jean-Marie Teno set in Burkina Faso ten years later, a color image of a different theater visually echoes this very shot (figure 1). ${ }^{2} \mathrm{~A}$ central aisle runs between the sections of metal chairs and benches drawing the spectator's eye to the white screen, pointing to the decline of spectatorship at movie theaters. Mahamat-Saleh Haroun's and Jean-Marie Teno's films attempt to grapple with the underlying paradox represented by the empty movie theaters, that African audiences cannot access African films.

Fig. 1
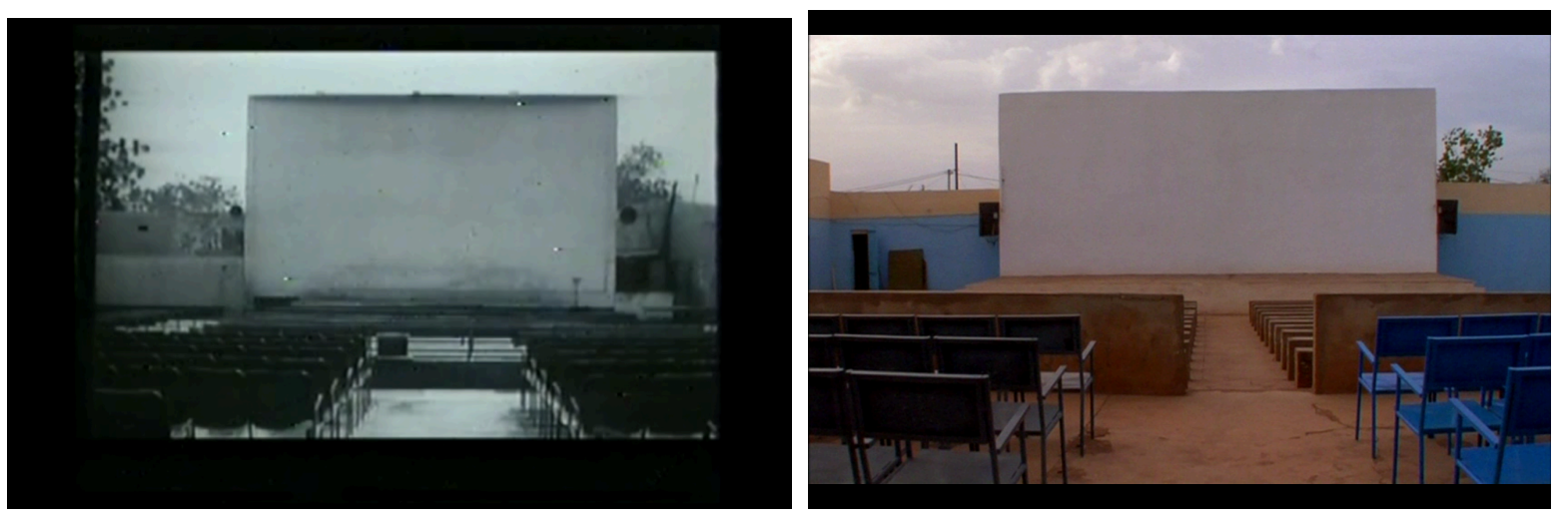

Bye Bye Africa and Lieux Saints address and engage with contemporary issues concerning African filmmaking and spectatorship. As Chad's first feature-length film, Bye Bye Africa seeks to define, and create, a future of cinema in the country. It blends fiction and

\footnotetext{
${ }^{1}$ Bye Bye Africa, directed by Mahamat-Saleh Haroun (San Francisco, CA: California Newsreel, 1999), VHS.

${ }^{2}$ Lieux Saints, directed by Jean-Marie Teno (Issy-les-Moulineaux, France: Les Films du Raphia, 2009), DVD.
} 
documentary filmmaking strategies, and assesses the present state of cinema in Chad while probing the question of how to make films for Chadians from ideological and practical standpoints. In Lieux Saints, a documentary that mixes modes, the stakes remain similar, as it also reflects on the present and future of African cinema. Prompted by claims about "African cinema's demise at the turn of the millennium," in the words of Michael Martin and Marissa Moorman, Teno reflects on how it is that residents of a poor neighborhood of Ouagadougou have little access to African films in the city that is hailed the capital of African cinema. ${ }^{3}$ Teno films during the 2007 Festival Pan-Africain du Cinéma et de la Télévision de Ouagadougou (FESPACO), the world's largest celebration of African cinema occurring every two years. ${ }^{4}$ The setting allows Teno to revisit African cinema's past while questioning its future, and to consider new generative possibilities for film and cultural production.

Haroun's and Teno's films reflect upon their contexts of production by giving thematic and formal attention to the larger situation of contemporary African filmmaking. In their respective settings, they emphasize that African films lack audiences, certain types of venues, and relevance to daily life. African films' lack of popularity is a subject taken up by a film that predates Bye Bye Africa and Lieux Saints. Jean-Pierre Bekolo’s “polemical film essay," Aristotle's Plot (1996), was the first film to address the situation of African cinema explicitly. ${ }^{5}$ This is a seminal film for this chapter as it set in motion a metanarrative about African cinema that Bye Bye Africa, Lieux Saints, and other films in this dissertation have continued. Aristotle's

${ }^{3}$ Michael T. Martin and Marissa Moorman, "The Civilising Mission of Globalisation," Third Text 29, no. 1-2 (2015), 64.

${ }^{4}$ The festival originated in 1969 and in 1972 acquired permanent structures. It is a major gathering of cinephiles, non-professionals and professionals of African cinema.

5 Jonathan Haynes, "African Filmmaking and the Postcolonial Predicament: Quartier Mozart and Aristotle's Plot," in Cinema and Social Discourse in Cameroon, ed. Alexie Tcheuyap (Bayreuth: Thielmann and Eckhard Breitinger, 2005), 118. Aristotle's Plot, directed by Jean-Pierre Bekolo (1996; Paris: JBA Production, 2004), DVD. The film has two versions, one in English and one in French, Le complot d'Aristote. I refer to the English version, which is the original one. 
Plot explores the relation between African filmmakers and African audiences through the conflict of the tsotsis, who are obsessed with Hollywood action films, and an African filmmaker, who has just returned home from Europe and who values "traditional" and "authentic" African narratives. The film's self-reflexive stance regarding the larger situation of African cinema and deconstruction of conventional storytelling devices have prompted many critical studies. ${ }^{6}$ Aristotle's Plot primarily targets the narrative and aesthetic tendencies of African films as responsible for the divorce between African filmmakers and their audiences. As Jonathan Haynes states,

Bekolo does not really address the material conditions which are doubtless more responsible for the divorce between African filmmakers and their audience than the slow pacing and rural settings of African films-conditions which have prevented his own films from reaching a mass popular audience in Africa. ${ }^{7}$

Bye Bye Africa and especially Lieux Saints foreground material conditions and, in a sense, continue and expand the reflection on African cinema that Bekolo began with Aristotle's Plot. Relatively few scholars have written about Bye Bye Africa and Lieux Saints, and reading them side by side reveals an ongoing effort on the part of African filmmakers to redefine their role and the use of performative strategies in particular to achieve these aims.

\footnotetext{
${ }^{6}$ Akin Adesokan, Postcolonial Artists and Global Aesthetics (Bloomington: Indiana University Press, 2011), pages 108-32; Kenneth W. Harrow, Postcolonial African Cinema: From Political Engagement to Postmodernism (Bloomington: Indiana University Press, 2007), pages 140-62; David Murphy and Patrick Williams, Postcolonial African Cinema: Ten Directors (Manchester: Manchester University Press, 2007), pages 200-203; Lindiwe Dovey, African Film and Literature: Adapting Violence to the Screen (New York: Columbia University Press, 2009), pages 205-17; Matthias de Groof, "How Text Reflects Context: Representation of African Film Audiences in Aristotle's Plot," Journal of African Cinemas 5, no. 2 (2013): 181-202; de Groof, "Intriguing African Storytelling: On Aristotle's Plot by Jean-Pierre Bekolo," in Storytelling in World Cinemas Vol. 1 - Forms, ed. Lina H. Khatib (New York: Columbia University Press, 2012): 115-31; Haynes, "African Filmmaking and the Postcolonial Predicament," 112-36; Rachael Langford, "Re-Reading Migrancy in Film History, Form, and Genre: Bekolo's Le Complot d'Aristote/Aristotle's Plot (1996) and Kouyaté's Ouaga Saga (2004)," Transnational Cinemas 4, no. 1 (2013): 89107.

${ }^{7}$ Haynes, "African Filmmaking and the Postcolonial Predicament," 132.
} 
In Bye Bye Africa and Lieux Saints, respectively, Haroun and Teno both examine and enact the subjects they explore, and in this sense their films are reminiscent of performative documentary according to Stella Bruzzi’s approach to the mode. Bruzzi posits that performative documentaries "simultaneously both describe and perform an action." ${ }^{8}$ Her approach draws primarily on J. L. Austin's “performative utterances” and Judith Butler's work on gender identity and performance. Bruzzi identifies two broad categories of documentary that could be considered performative: "films that feature performative subjects and films that are inherently performative and feature the intrusive presence of the filmmaker." ${ }^{9}$ Bye Bye Africa is performative in the latter sense, even though it hovers between fiction and documentary. Bruzzi's model also sheds light on the formal implications of Bye Bye Africa's use of performance. She claims that performativity stems from an impulse on the part of the filmmaker to "acknowledge the construction and artificiality of even the non-fiction film." ${ }^{\prime 10}$ The film's primary narrative and aesthetic strategy is a performance of making a film with the larger project of seeking to build a future of cinema in Chad. Like the documentarians in Bruzzi's study, Haroun accentuates Bye Bye Africa's means of production by drawing attention to the challenges and issues of filmmaking in Chad, and Africa. This demonstrates Haroun's understanding that masking the film's means of production is an "impossibly utopian" gesture, a germane strategy to the new performative documentary according to Bruzzi. ${ }^{11}$

Performativity in Lieux Saints straddles Stella Bruzzi's and Bill Nichols' approaches to the mode. Debates in documentary theory surrounding the notion of the performative are varied

\footnotetext{
${ }^{8}$ Bruzzi, New Documentary: A Critical Introduction (London: Routledge, 2000), 154.

9 Ibid., 155. Similarly, Paul Ward writes, "all documentary (and indeed all social interaction) involves people 'acting' in some sense of the term." Ward, Documentary: The Margins of Reality (London: Wallflower Press, 2005), 36.

10 Bruzzi, New Documentary, 8.

11 Ibid., 155.
} 
and inconclusive, as George Larke-Walsh notes, and this is evident in Bruzzi and Nichols' divergent stances. ${ }^{12}$ Indeed, whereas Bruzzi defines performative documentary in the sense of speech acts, conversely, Nichols argues that performative documentaries do not perform the actions they name. ${ }^{13}$ In his approach to the mode, Nichols defines performance as drawing heavily on the tradition of acting "as a way to bring heightened emotional involvement to a situation or role." Performative documentaries, he continues, "want us to feel on a visceral level more than understand on a conceptual level.. ${ }^{14}$ In Lieux Saints, Teno-as director, author, and voice-over narrator-adopts an introspective stance, and uses the historical past as a powerful tool to construct meaning; these aspects relate to Nichols' definition of the performative as documentaries whose "expressive dimension refers us back to the historical world for its ultimate meaning." ${ }^{.15}$ According to Nichols, performative documentary treats knowledge as embodied and affective, and "freely mixes expressive techniques that give texture and density to fiction... with oratorical techniques for addressing social issues." ${ }^{, 16}$ One strategy illustrative of this "expressive" dimension in Lieux Saints is the inclusion of the figure of a djembe musician. But beyond bringing the emotional intensities of his subjects to the fore, Teno's film seeks to do something tangible; in this sense it also embodies Bruzzi's concept that "documentaries, like Austin's performatives, perform the action they name," to a certain degree. ${ }^{17}$ The film raises questions regarding the future state of African cinema, and it also deploys narrative and aesthetic strategies that signal new creative possibilities for the art form.

\footnotetext{
12 George S. Larke-Walsh, "Point Your Finger and Say, 'That's the Bad Guy"”: Performativity in Donal MacIntyre's A Very British Gangster (2007)," Journal of Film and Video 64, no. 3 (Fall 2012), 57.

${ }^{13}$ Nichols, Introduction to Documentary, 2nd ed. (Bloomington: Indiana University Press, 2010), 203.

${ }^{14}$ Ibid.

15 Ibid., 206.

${ }^{16}$ Ibid.

${ }^{17}$ Bruzzi, New Documentary, 156.
} 
The films' performative strategies correspond to their aim of seeking to define the future of African cinema. Instead of simply naming the inherent issues in filmmaking and spectatorship on the continent, both films put into practice a mode of representation that seeks to resolve the very issues that they name, at least in part. This mode of representation is distinct in each film, however, each involves the presence of the filmmaker. Haroun and Teno, respectively, comment on the action with voice-over narration, and appear on-screen, which constantly reminds the viewer of the film as construct. Redefining the future of African cinema inevitably entails reflecting on the filmmaker's role and, as I demonstrate below, each filmmaker displays an acute awareness of this, and suggests a new role for the African filmmaker.

My analysis of the two films builds upon Dayna Oscherwitz' chapter on Bye Bye Africa and Justin Izzo's article on Lieux Saints, the sole in-depth studies devoted to each film, which I discuss further at the beginning of each film section. ${ }^{18}$ Neither critic considers the notion of performativity in their approach. Melissa Thackway and Rachel Gabara formulate ideas about films by Jean-Marie Teno, David Achkar, and Mahamat-Saleh Haroun that touch upon aspects of the performative explored in this chapter. Thackway observes that "direct authorial intervention" is marked in Jean-Marie Teno's Afrique, je te plumerai (1992) and to a lesser degree in David Achkar's Allah Tantou (1991), by noting each filmmaker's personal presence and use of voiceover narration as a means to convey a committed point of view. ${ }^{19}$ With respect to the same titles by Teno and Achkar as well as Haroun's Bye Bye Africa, Rachel Gabara identifies similar characteristics to those mentioned by Thackway, and connects the strategy to Italian Neorealism

\footnotetext{
${ }^{18}$ Dayna Oscherwitz, "Bye Bye Hollywood: African Cinema and Its Double in Mahamet-Saleh (sic) Haroun's Bye Bye Africa," in Hollywood's Africa After 1994, ed. MaryEllen Higgins (Athens, OH: Ohio University Press, 2012): 240-59; Justin Izzo, "Jean-Marie Teno's Documentary Modernity: From Millennial Anxiety to Cinematic Kinship," African Studies Review 58, no. 1 (April 2015): 39-53.

${ }^{19}$ Melissa Thackway, Africa Shoots Back: Alternative Perspectives in Sub-Saharan Francophone African Film (Bloomington: Indiana University Press, 2003), 99.
} 
and the New Latin American documentary. ${ }^{20}$ Gabara also stresses reflexivity as a central strategy in these films. My approach to Bye Bye Africa and Lieux Saints builds upon Gabara's and Thackway's important observations. Whereas previous discussions about African documentaries, such as N. Frank Ukadike's, tend to emphasize documentary's pursuit of the purity of the real (film as record), Thackway, Gabara, and especially this chapter agree with Stella Bruzzi's view, that documentary is the "perpetual negotiation between the real event and its representation." 21 Taking into account that the subject of Bye Bye Africa and Lieux Saints are cinema (broadly defined) and African cinema in particular, Bruzzi's underlying thesis, that "documentary does not perceive its ultimate aim to be the authentic representation of the real," corresponds to Haroun's and Teno's performative strategies. They step in at a critical juncture and seek to shape and alter the cinematic landscape of which they are part.

In their forward-looking volume, Frieda Ekotto and Kenneth Harrow argue that it is impossible to understand African cultural production without knowledge of the structures of production, distribution, and reception that surround them. ${ }^{22}$ I agree, and would add that these two films themselves demonstrate this very claim-that is, Haroun and Teno address and engage with the contexts of production, distribution, and reception, which have become urgent matters

${ }^{20}$ Rachel Gabara, “'A Poetics of Refusals': Neorealism from Italy to Africa,” Quarterly Review of Film and Video 23 (2006), 212. Gabara's discussion of these films appears at the end of her study. She concludes by proposing the development of a new genre that shares the concerns and some characteristics with Neorealism and the New Latin American documentary, which she terms the "New African Documentary." Films that deploy this "genre which itself mixes genres," layer "autobiographical, biographical, and historical (both national and international), and first, second, and third-person narratives" (ibid., 212). In a later article, Gabara applies this definition to Sissako's works. Gabara, "Abderrahmane Sissako: Second and Third Cinema in the First Person," in Global Art Cinema: New Theories and Histories, ed. Rosalind Galt and Karl Schoonover (Oxford: Oxford University Press, 2010): 320-33.

${ }^{21}$ N. Frank Ukadike, "The Other Voices of Documentary: Allah Tantou and Afrique, je te plumerai," in Focus on African Films, Françoise Pfaff, ed. (Bloomington: Indiana University Press, 2004): 159-72. Bruzzi, New Documentary, 9. The idea that documentary's ultimate aim is to record events as authentically as possible surfaces in theoretical texts such as Erik Barnouw's, according to Stella Bruzzi. Barnouw, Documentary: A History of the Non-Fiction Film, 2nd ed. (Oxford: Oxford University Press, 1993).

${ }^{22}$ Frieda Ekotto and Kenneth Harrow, eds., Rethinking African Cultural Production (Bloomington: Indiana University Press, 2015). 
and to mask or overlook them is, to recall Stella Bruzzi's expression, an "impossibly utopian" gesture.

\section{Bye Bye Africa (1999)}

When Mahamat-Saleh Haroun started making films in Chad in the 1990s, he began a tradition of filmmaking in his native country where, up until that point, the only films shown were foreign. Without images to identify with, Chadians risked undergoing what Haroun calls a "colonization by images." 23 One of only two directors from Chad, along with Issa Serge Coelo, Mahamat-Saleh Haroun is the country's leading filmmaker. Since Bye Bye Africa, his first feature-length film, which is also the first from Chad, he has written and directed four features that mark his style as minimalist and meditative: Abouna (Our Father, 2002), Daratt (Dry Season, 2006), Un homme qui crie (A Screaming Man, 2010), and Grigris (2013). All of these features are unambiguously fictional, whereas Bye Bye Africa experiments with modes, hovering between documentary and fiction. Haroun's fundamental project, to "make Chad 'exist' visually to the outside world," has been a successful one that in turn has garnered him increased support. ${ }^{24} \mathrm{He}$ gained international attention by winning the Jury Prize at the Cannes Film Festival in 2010 with Un homme qui crie, and for the first time received funding from the Chadian government for Grigris. But prior to achieving success and recognition within Chad and beyond, Haroun faced numerous challenges with respect to filmmaking, a topic he explores in Bye Bye Africa.

\footnotetext{
${ }^{23}$ Stuart Jeffries, "Out of Africa," The Guardian, November 14, 2002, http://www.theguardian.com/culture/2002 /nov/15 /artsfeatures3.

24 James S. Williams, "Male Beauty and the Erotics of Intimacy: The Talismanic Cinema of Mahamat-Saleh Haroun," Film Quarterly 67, no. 4 (Summer 2014), 34.
} 
The film's primary narrative and aesthetic strategy performs making a film with the larger project of seeking to build a future of cinema in Chad. In the film, cinema refers concretely to movies, movie theaters, and making films. More abstractly, it also connotes an understanding and appreciation of the art form and, by extension, a tradition of filmmaking by and for Chadians. Through the main character's investigation of the state of cinema and his activities preparing a film, Bye Bye Africa highlights challenges that prevent cinema from thriving in each of these senses. Mahamat-Saleh Haroun plays the role of the main character, a filmmaker named Haroun, who has been residing in France but returns to his native Chad after receiving the news of his mother's death. Upon his arrival in N'Djamena, Chad's capital city, he decides to make a film dedicated to his mother's memory called Bye Bye Africa. His film project is ostensibly in its initial stages, which involves seeking funding and holding cast auditions. The film alternates between color images that form the narrative, and black-and-white images from his hand-held camera. The final sequence depicts the departure of Haroun, although he states his intention to return very soon to shoot Bye Bye Africa.

Bye Bye Africa does not claim to be either fiction or documentary and defies simple classification. Indeed, Roy Armes writes that its "mixture of observation and enactment is so complex that it is difficult to know whether to call it a documentary fiction or a fictional documentary. ${ }^{25}$ The film blends fiction and documentary filmmaking strategies, leaving viewers wondering to what degree the narrative events are constructed or rehearsed. The idea that there is a straightforward distinction between fiction and documentary "has such a strong culturally accepted existence that some writers, particularly of articles and reviews intended for a general

${ }^{25}$ Roy Armes, Filmmaking North and South of the Sahara (Bloomington: Indiana University Press, 2006), 159. 
audience, take it for granted," writes Alison Levine. ${ }^{26}$ Similarly, Bill Nichols points out that the "division of documentary from fiction [...] is a matter of degree as opposed to one that is strictly defined." 27 Levine elucidates a key distinction between fiction and documentary, or non-fiction: the referent. In non-fiction, she writes, "it is the world, that of lived experience, whereas in fiction, it is $a$ world, one that 'yields to the demands of a creative vision' and never actually existed" (emphasis in original). ${ }^{28}$ She explains further that in documentary, "the signifier is a framed image assumed to be plucked from historical experience, whereas in fiction film, it is a framed image assumed to be constructed for the occasion." ${ }^{, 29}$ Bye Bye Africa refers both to a fictional world invented by the filmmaker as well as to the historical world. The film exhibits conventions common to many documentaries, including interviews, voice-over, and people who present themselves in their everyday roles and activities. At the same time, it features actors playing characters, and invents the death of Haroun's mother, the key event that shapes the film's narrative. ${ }^{30}$ In Bye Bye Africa Mahamat-Saleh Haroun willfully destabilizes the boundaries between the two modes as a way of offering a meditation on the nature of cinema (broadly defined) and African cinema in particular.

Beyond mixing fiction and documentary strategies, Mahamat-Saleh Haroun blurs the line between on- and off-screen worlds through his presence in the frame. ${ }^{31}$ Indeed, as Armes states, “particularly complex is Haroun's own status not only as director and scriptwriter, but also as

\footnotetext{
${ }^{26}$ Alison J. Murray Levine, “'Provoking Situations': Abderrahmane Sissako’s Documentary Fiction,” Journal of African Cinemas 3, no. 1 (2011), 94.

27 Nichols, Introduction to Documentary, 12.

${ }^{28}$ Levine, “Provoking Situations,"” 94. In this passage, she cites Michael Renov (1993).

29 Ibid.

${ }^{30}$ While discussing his approach to making Bye Bye Africa during Los Angeles County Museum of Art's Caméra d'Afrique series in October 2013, Mahamat-Saleh Haroun mentions that the death of his mother did not occur. Film Independent. "Mahamat-Saleh Haroun: Film Independent at LACMA," YouTube video, 20:19. October 14, 2009, https://www.youtube.com/watch?v=Vft4pqmbiOA.

31 Throughout my discussion of the film, I use Mahamat-Saleh Haroun when referring to the director, and Haroun to identify his character in the film.
} 
both authenticating voice-over narrator, Haroun, and lead actor, a seemingly fictional version of himself." 32 Further, he plays a director figure in a narrative that revolves around the creation of a film, one that bears strong resemblance to the one the viewer is watching. By casting himself as a filmmaker, he places himself at the center of the process that brings the film into being; he thereby exemplifies Jean-Luc Godard's approach to filmmaking, which he famously described as "to show and to show myself showing." 33 According to Linda Rugg, a director's "selfprojection" involves the "assertion of a presence." "34 The notion of "asserting a presence" is central to Mahamat-Saleh Haroun's project in Bye Bye Africa, as it entails mapping the existence of Chad, its cinema, and himself. He simultaneously enhances and attenuates this gesture by revealing the cinematic apparatus and, especially, various factors that impede film production. This demonstrates Haroun's understanding that masking the film's means of production is an “impossibly utopian” gesture, as Stella Bruzzi writes regarding a strategy germane to the new performative documentary. ${ }^{35}$ Like the documentarians in Bruzzi’s study, Haroun accentuates Bye Bye Africa's means of production by drawing attention to the challenges and issues of filmmaking in Chad, and Africa. At the same time, it addresses and engages with the broader question of a film's relationship to reality. ${ }^{36}$

My argument builds upon Dayna Oscherwitz', whose article is the only full-length study solely devoted to the film to date. She skillfully demonstrates how Bye Bye Africa constitutes a sort of manifesto of what African cinema should hope to achieve, by examining the nature of the images recorded by each camera. While her article details how the film accomplishes this

\footnotetext{
32 Armes, African Filmmaking North and South of the Sahara, 159.

33 Cited in Cecilia Sayad, Performing Authorship: Self-Inscription and Corporeality in the Cinema (New York: I.B. Tauris, 2013), 12.

${ }^{34}$ Linda Rugg, Self-Projection: The Director's Image in Art Cinema (Minneapolis: University of Minnesota Press, 2014), 176. By director (auteur) she means $s /$ he who is identified as the source of the vision on the screen.

35 Bruzzi, New Documentary, 155.

36 Ibid., 153.
} 
thematically, it does not amply develop it on a formal level. For instance, she classifies the sequences recorded by Haroun's camera as "fairly typically documentary," for the fact that they consist mostly of "interviews with people who have a connection to cinema in Chad."37

However, the images recorded by Haroun's camera also defy documentary conventions. Overall, Oscherwitz' study leaves room for the film to be re-assessed, beginning with key details, including the fact that the film was shot on analog video as opposed to digital, and nearly a decade later than she claims. ${ }^{38}$

\section{Documenting the State of Cinema in Chad}

On a thematic level, Bye Bye Africa is obviously about cinema. The film is organized around Haroun's investigation of the state of cinema in Chad, and it is explicit in the dialogue and in the voice-over narration. While the catalyst for Haroun's journey to his native country is ostensibly the death of his mother, the film conflates his mother's death with that of cinema in Chad. Indeed, as key moments early in the film indicate, Haroun's mother symbolically represents the situation of cinema in Chad and, more broadly, the cinema. In the first moment where Haroun mentions his film project, he presents a eulogy presumably for his mother, but the ambiguity inherent in his statement is emphasized by the fact that there is virtually no mention of his mother throughout the remainder of the film. The camera frames Haroun from behind as he looks out at the towers of a mosque in the distance; the sound of the call to prayer lingering in the background casts a reverential tone on this moment. In voice-over, Haroun expresses his deep regret over missing his mother's funeral and the chance to see her face one last time. He explains that cinema is the only way to relieve his sorrows, and a way to pay homage to his

\footnotetext{
${ }^{37}$ Oscherwitz, "Bye Bye Hollywood," 246.

${ }^{38}$ Bye Bye Africa was shot on Beta SP and was transferred to 35mm for its release in 1999 (not 1991, as Oscherwitz lists). Armes, African Filmmaking North and South of the Sahara, 159.
} 
mother: "Je sens l'immense besoin de me réfugier quelque part. Dans le cinéma, sans doute. Pour tuer mon chagrin, je vais faire un film à la mémoire de celle qui m’a donné la vie. ${ }^{, 39}$ In this context, the demonstrative pronoun celle refers to Haroun's mother, yet it is also somewhat ambiguous, given that he opts for a pronoun instead of explicitly naming her.

As indicated by this example, the film engenders doubt about its subject, which reflects its larger project of blurring the line between representation and reality. This strategy fluctuates throughout Bye Bye Africa. For instance, the ambiguity between reality and representation is less pronounced in sequences dealing with movie theaters and the cinematic exhibition infrastructure than it is in other sequences. Even as the image alternates between those taken by the color, or the external camera, and those taken by Haroun's camera in black and white, the viewer senses that the representation of reality is authentic. Along with his friend Garba, Haroun tours three cinemas, two of which are no longer in operation. A color image focuses on the two men riding on the motorbike to the Normandie, the first theater, as Haroun makes an apt observation regarding the scale of degradation in voice-over: "A l'évidence le cinéma fout le camp ici." ${ }^{40}$ In a wide shot of the cinema's exterior, Garba and Haroun pull up on the bike and dismount, then the shot cuts to black-and-white footage from Haroun's hand-held camera from inside the theater. Haroun carefully pans around the center of the room and along the perimeter, revealing crumbling walls, missing ceiling tiles, and heaps of broken seats (figure 2). Like a eulogy, the footage from his camera pays tribute to the memory of what the dilapidated setting once was. Accompanying Haroun's slow and deliberate filming is Garba's remark that cinema has no future here, presumably referring to both at the Normandie as well as in Chad. Their subsequent visits to the Étoile and the Sheherazade comprise similar moments in which Haroun films the

\footnotetext{
39 "I feel the immense need to take refuge somewhere. In the cinema, most likely. To rid my sorrows, I am going to make a film in memory of the one who gave me life." Translations provided by the film's subtitles.

40 "Clearly, the industry is crumbling here."
} 
still, silent spaces with his camera. The Étoile is little more than a vacant courtyard, whereas the Sherherazade is currently running, although it is in poor condition. Shots from Haroun's camera at this latter establishment feature dusty film cans stacked on the floor (figure 3), dated projection equipment, and rows of empty seats before a blank screen.
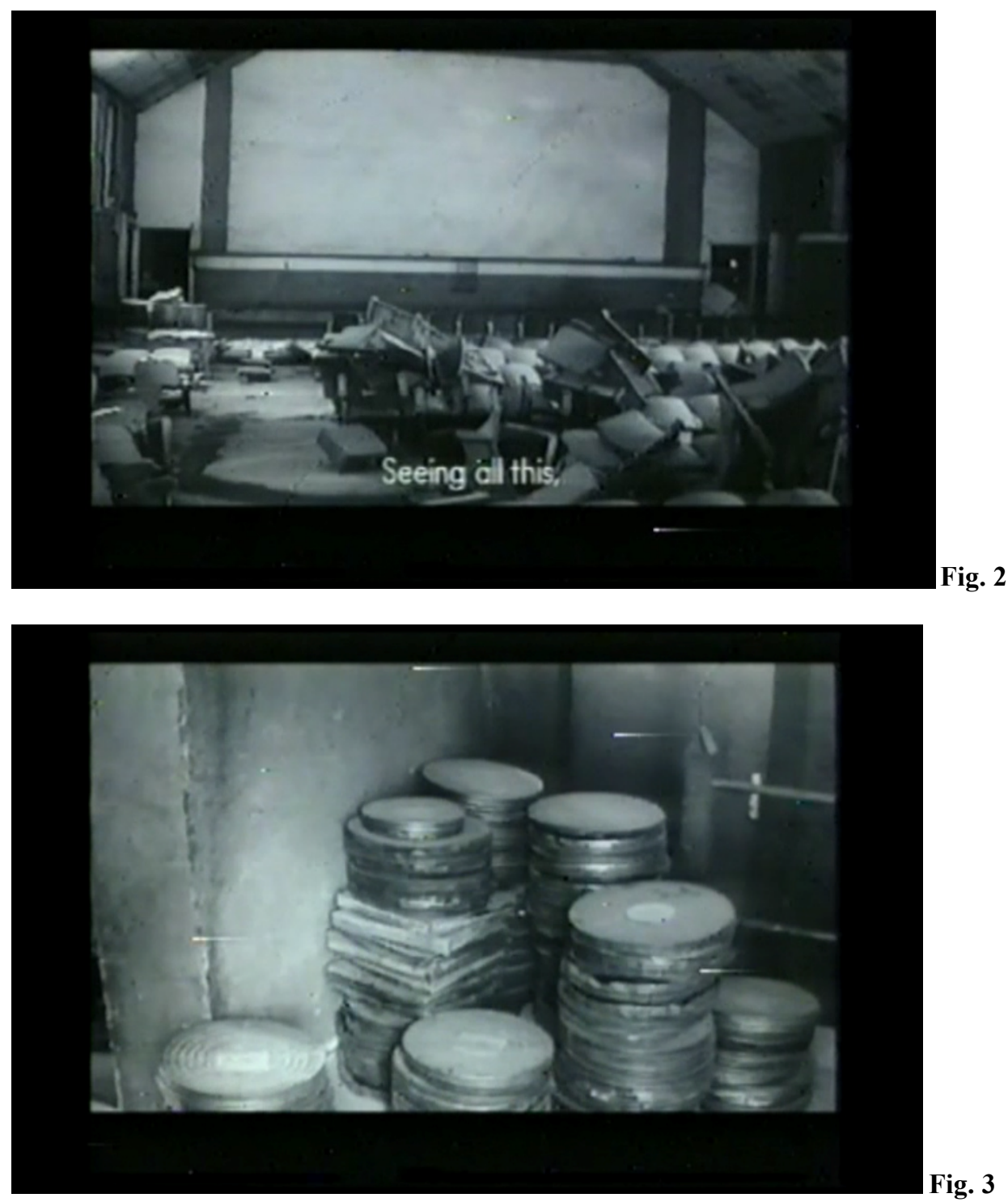

Haroun's personal connection with cinema shapes his investigation; this dimension is evident, for instance, when he outlines his quest in voice-over: “Où sont donc passés les cinémas de mon enfance? Le Normandie, bien sûr, mais aussi le Shéhérazade, le Rio, le Vogue-qui s’est 
transformé en hotel-et l'Étoile." ${ }^{41}$ As he revisits and commemorates the cinemas of his past, Haroun connects to collective consciousness by recalling Chad's civil war. ${ }^{42}$ References to historical events such as this further anchor the film in historical reality, undoing the sense of doubt that arises from the film's ambiguous relationship to reality, at least momentarily. The material dilapidation of Chad's movie theaters is primarily a result of civil war. The current owner of the Étoile cinema explains to Haroun that the building was a thriving venue for movie screenings as well as theater performances up until the war in N'Djamena in 1979 to 1980. The movie theaters continue to bear traces of the past, with facades lined with bullet holes. The war's lasting effects are also noticeable in the realm of distribution. Many prints were destroyed during the events of war, explains the video-club manager Haroun interviews. As a result, the manager explains, movie theaters in the city no longer receive films through distribution circuits. In addition to the war's lasting effects on a material level, the war sentiment has penetrated deep into the social fabric of the country, leading Haroun to wonder if there is even a place for cinema. In voice-over, he asks rhetorically: "Comment croire au cinéma dans un pays où la guerre est devenue une culture?"43 Indeed, the film alludes to a pervasive sense of violence. For instance, when Haroun and Garba exit the Normandie, a brawl spontaneously breaks out among groups of young men on the steps of the theater. Despite the fact that the theater is closed, it metonymically signifies movies, and thus their actions may seek to imitate the fighting depicted in action flicks that play at the remaining venues and on television. This behavior is in fact visible in locations beyond N'Djamena, such as Douala, Cameroon, where "the biggest gangs

\footnotetext{
41 "What has happened to the movie theaters from my youth? The Normandie, of course, but also the Sheherazade, the Rio, the Vogue, which was made into a hotel, and the Etoile."

42 Chad's civil war is the reason Mahamat-Saleh Haroun initially left the country and moved to France.

43 "How is it possible to believe in the cinema of a country where war has become a culture?" This sentence is evocative of the on-screen text in Bekolo's Les Saignantes, which I discussed in Chapter Two.
} 
meet around movie theaters...it is here that the violence seen in the movies is acted out," writes Jean-Pierre Bekolo. $^{44}$

\section{Disconnection between Filmmakers and Audiences}

The depiction of violence and remnants of war allow Mahamat-Saleh Haroun to acknowledge factors that limit the flourishing of cinema in the country. In this vein, the film explores the alienation between African filmmakers and audiences as another limiting factor. According to Lindiwe Dovey, a filmmaker's "mobility," which refers to frequent travel and/or residence outside of the continent, "raises questions about their potential to relate emotionally and intellectually to local audiences in Africa." ${ }^{45}$ In Bye Bye Africa, Haroun's detachment from Chad exemplifies this theme, which is first explored through emphasis on Haroun's expatriate status. Indeed, before identifying him as a filmmaker, the film marks him as living in exile and by extension, as an outsider. Rather than depicting his journey from Paris to N'Djamena, the film represents it as a brief jump in time. A point-of-view shot looking through the rear window of a cab driving along the Seine cuts to a point-of-view shot through the windshield of a cab in the streets of Chad's capital city. The change in music further signifies that a change in space and time has taken place. Oscherwitz aptly reads the absence of a journey as a lack of mental transformation or development of a character that journeys in films typically entail. As a result, "Haroun arrives in Chad with a mind-set and worldview identical to the one he had in France," she writes. ${ }^{46}$ Indeed, his worldview, as the film later indicates, is detached from his native culture, and is more in line with a European mind-set.

\footnotetext{
44 Jean-Pierre Bekolo, “Aristotle's Plot," in African Images: Recent Studies and Text in Cinema, ed. Kenneth Harrow and Emmanuel Yewah (Trenton: Africa World Press, 2000), 27.

${ }^{45}$ Lindiwe Dovey, Curating Africa in the Age of Film Festivals (New York: Palgrave Macmillan, 2015$), 7$.

46 Oscherwitz, "Bye Bye Hollywood," 248.
} 
To further emphasize Haroun's status as an outsider, the film sets up a trope of movement within its visual and spatial economy. Many sequences take place in the streets of N'Djamena, which are "in-between spaces, spaces of movement and not of arrival," as Alison Levine writes, and feature Haroun riding on a motorbike (often as a passenger behind his friend, Garba) (figure 4). ${ }^{47}$ These shots tend to mark a transition between sequences and usually depict getting from one place to another. However, the frequency of these street scenes, along with the theme of Haroun's detachment from his native country, illustrate a transient nature that is tied to Haroun's status as an exile, and evoke the notion that he has not fully arrived but is only passing through, hovering somewhere between his native country and country of residence.
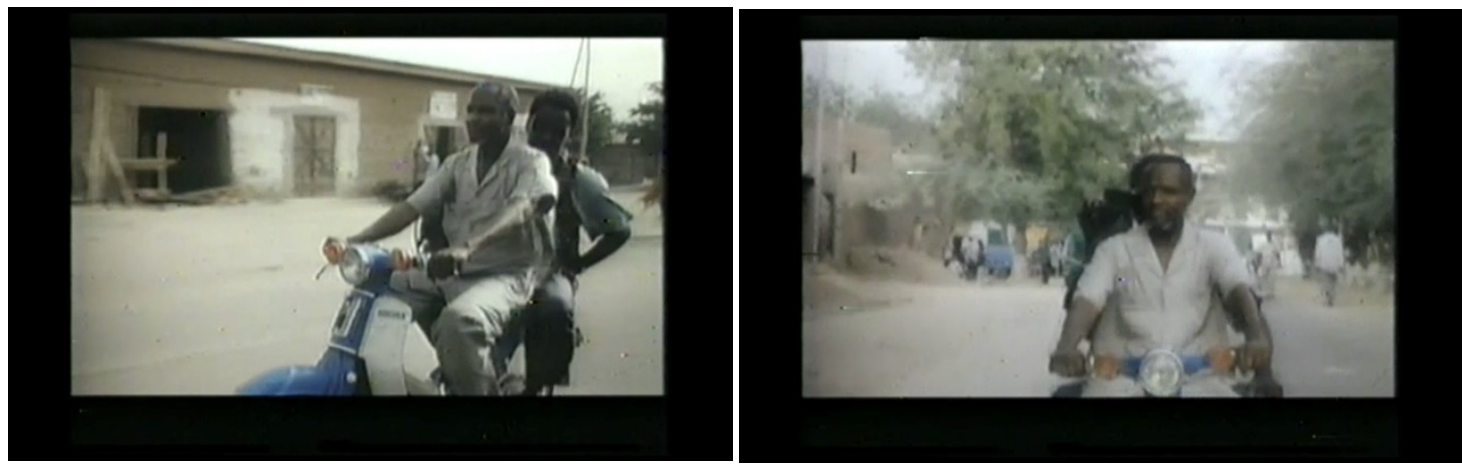

In addition to emphasizing Haroun's detachment from his native country through formal devices, the film raises the issue of alienation between filmmakers and audiences through dialogue. A sequence between Haroun and his father that occurs shortly after Haroun's arrival in Chad illustrates this theme. His father believes that his son's films are not made for Africans, due especially to the Eurocentric subject matter. As the two men walk through a soccer field, Haroun films aimlessly with his video camera and his father disparages his son's profession and expresses his incomprehension of film. He states in Arabic: "We don't understand what you do.

\footnotetext{
${ }^{47}$ Alison J. Murray Levine, “'Provoking Situations': Abderrahmane Sissako's Documentary Fiction,” Journal of African Cinemas 3, no. 1 (2011), 96. Levine identifies this trope in Abderrahmane Sissako's films La vie sur terre and Heremakono. Further comparison of these films with Bye Bye Africa may yield a broader trope in films by exilic African filmmakers.
} 
You sent a tape. Didn't understand. Just bla bla. It was about a European.” When Haroun replies that it focused on Freud, his father asks if Freud is his mate. His father's remarks highlight Haroun's lack of engagement with his audience through his film's inability to speak to his father, although, given the close connection between Haroun and Mahamat-Saleh Haroun, the idea is ironic. Oscherwitz also suggests that his father's remarks convey the need for a "personal connection between a filmmaker and his films if there is to be a connection between an audience and film. It is this connection that Haroun seems to lack." ${ }^{, 48}$

Haroun's inability to connect with his audience on a meaningful level stems in part from his incomprehension of the general cultural attitude toward cinema in his native country. Garba explains that he has spent too much time abroad to understand Chadians' relationship to film: “On a un gros problème avec les images. On n'arrive pas à faire la différence entre la fiction et la réalité." 49 The film explores this idea through the tragic story of Isabelle, an actress who played the part of a character with AIDS in Haroun's film on the topic. Her family and entire community ostracized her after it aired, because they believed that she actually carried the disease. She ultimately commits suicide, an event the film presages when she tells Haroun, "Ton film m'a tuée. Le cinéma est plus fort que la réalité." ${ }^{50}$ While Haroun comports himself as a "callous lothario" towards Isabelle, in the clever wording of James Williams, his general attitude as that of a filmmaker who is divorced from his country and audiences is designed to show how not to be. ${ }^{51}$ Indeed, the critique of alienated filmmakers is part of Mahamat-Saleh Haroun's larger project of performing how (not) to make a film in Chad.

\footnotetext{
48 Oscherwitz, "Bye Bye Hollywood," 249.

49 "We have a big problem with images. We cannot distinguish between fiction and reality."

50 "Your film has killed me. The cinema is stronger than reality."

51 Williams, "Male Beauty and the Erotics of Intimacy," 34.
} 


\section{Bye Bye Africa, or, How Not to Make a Film in Chad}

The above comment made by Garba, “On n’arrive pas à faire la différence entre la fiction et la réalité," captures the essence of Bye Bye Africa. The blurring of fiction and reality is especially pronounced concerning Haroun's fictional film project, also called Bye Bye Africa. Despite the identical titles, there is ambiguity surrounding the degree to which his character's film project corresponds to the completed film, or the one that the viewer is watching. This sense of ambiguity arises early in the narrative, when Haroun first mentions his project. He is riding on the motorbike behind Garba, and the men converse as Haroun captures pedestrians, vehicles, and storefronts from the moving bike. Filming from the standpoint of a moving vehicle creates an intertextual reference with Dziga Vertov's Man with a Movie Camera (1929), an early film that exemplifies the self-conscious, reflexive documentary tradition that Mahamat-Saleh Haroun is continuing in Bye Bye Africa. ${ }^{52}$ This moment highlights the film's reflexive approach, as Haroun directly refers to the film the viewer is watching:

Garba: Quand est-ce que tu vas faire un autre film?

Haroun: Dans un an, j'espère. Ça s'appelle Bye Bye Africa.

Garba: Ça parle de quoi?

Haroun: C'est difficile à dire. C'est un exercice à tiroir; ça parle du cinéma, de l'exil, de la famille, de l'amour, de la vie quoi. Comment filmer la vie? C'est la question que je me pose. $^{53}$

His project aspirations align in form and content with the completed film; it will also be experimental in nature and explore similar topics. These aspects conflate Haroun's next film

\footnotetext{
${ }^{52}$ Man with a Movie Camera, directed by Dziga Vertov (1929; New York, NY: Image Entertainment, 2002), DVD.

${ }^{53}$ Garba: "When are you going to make another film?" / Haroun: "In a year, I hope. It's called Bye Bye Africa. / Garba: "What is it about?" / Haroun: "It's hard to say. It's like a set of Russian dolls; it's about cinema, exile, family, love, life, really. How do you film life? This is the question that I explore."
} 
project with the completed one, but his intent to execute it in a year clearly sets it apart. Haroun reiterates the notion that his project is suspended somewhere in between the present and the future when he states the closing line of the film in voice-over: "Je sais que je reviendrai bientôt, très bientôt, pour tourner Bye Bye Africa. ${ }^{.54}$ Situating his project in the future self-consciously refers to the uncertainty, even impossibility, of his aims of making a film in Chad.

Bye Bye Africa adopts a reflexive approach to raise issues about its context of production. In the film's depiction of filmmaking in Chad, and Africa, Mahamat-Saleh Haroun dilutes the boundaries between the filmic world and the "real" world, while foregrounding the issues that prevent his character's Bye Bye Africa from being made. For instance, a Chadian producer refuses to provide financial backing and, following this meeting, Haroun tells Serge, a fellow filmmaker, "Bye Bye Africa, ça marche pas vraiment." ${ }^{, 55}$ Interestingly, the other filmmaker, who is played by Issa Serge Coelo, experiences his own difficulties. He is on set and ready to begin shooting, but cannot due to electricity problems that stem from an oil crisis in neighboring Nigeria.

In addition to Coelo, the film features another actual filmmaker, David-Pierre Fila from the Republic of the Congo. Unlike Coelo's character, he presents himself by his full name. He does not appear in the frame but speaks in voice-over, reading a letter that he sends to Haroun, which he opens and closes by stating his postal address. The reference to his address as well as to actual people, places, and events create the sense that the letter is written from the historical world to the filmic one, a ludic way to connect Bye Bye Africa to historical reality. In his letter, Fila acknowledges Haroun's film project, yet gives a description that more fittingly applies to the completed film the viewer is watching: "J'ai appris que tu prépares un film sur l'état du lieu du

\footnotetext{
54 "I know that I will return soon, very soon, to shoot Bye Bye Africa."

55 "Bye Bye Africa is not really working."
} 
cinéma chez toi au Tchad. ${ }^{, 56}$ Furthermore, he raises a question that implies the very stakes of Haroun's project, as well as those of the completed film the viewer is watching: "Comment croire tout à fait en un cinéma qui n'est plus sinon à travers les images que nous avons filmées?" ${ }^{, 57}$ Fila contextualizes his remarks within a larger framework by including a quotation from Aimé Césaire that mentions the "threat" facing local cultural production in materially "underdeveloped" cultures. ${ }^{58}$ When Césaire made his comment in 1956, the "threat" was imperialism, but his words resonate amidst the more current phenomenon of globalization and serve to reinforce the necessity of film creation in Africa, and Chad in particular.

Through the conflation of actual people with their semi-fictional or filmic counterparts, and Haroun's film project with the completed film, Bye Bye Africa addresses and engages with the issue of a film's relationship to reality. It further explores this issue by highlighting the negotiation between filmmaker and its subject(s)-that is, it demonstrates how "reality" is altered by the presence of Haroun's camera. The film features examples that span from positive to negative reactions from subjects, allowing for a commentary on how Chadians wish to be filmed, as well as how not to film them.

Haroun captures black-and-white images on his hand-held camera that are embedded into Bye Bye Africa's narrative. This technique locates his filming in the filmic present, even if it is impossible for him "to be operating both the film's external and internal cameras" according to "standard conventions of filmic narration," as Oscherwitz notes. ${ }^{59}$ The first time the viewer witnesses Haroun filming through his hand-held camera occurs immediately after his arrival in Chad. This moment establishes the illusion of convergence that characterizes the relationship

\footnotetext{
56 "I gather that you are working on a film on the conditions of cinema in your home country, Chad."

57 "How can we go on believing in a disappearing cinema other than through images that we have filmed ourselves?"

58 Césaire's remarks come from a speech he gave at the Premier Congrès des Ecrivains et Artistes Noirs, held at the Sorbonne in 1956.

59 Oscherwitz, "Bye Bye Hollywood," 247.
} 
between two cameras over the course of the film; they appear to operate in the same space and time. Haroun is seated in the front seat of a taxi cab conversing with the driver about the high price of gasoline and gas smuggling. ${ }^{60}$ He lifts his camera and looks through the viewfinder (figure 5). As he turns to face the driver, the shot cuts to a black-and-white close-up of the man; the frame of Haroun's camera becomes the frame of the film (figure 6). The driver turns his head and directly addresses the camera, stating in Arabic: "Yes, film me. Get me on the silver screen so people will see me in my cab at the steering wheel." This interaction introduces the theme of filming Africans as they wish to be filmed. The taxi driver, an ordinary citizen, conveys his desire to be represented in his everyday role and activity. This theme pertains to Mahamat-Saleh Haroun's larger project of building cinema in the country, and seeking to do so in a way that connects meaningfully to his subjects and potential audiences.

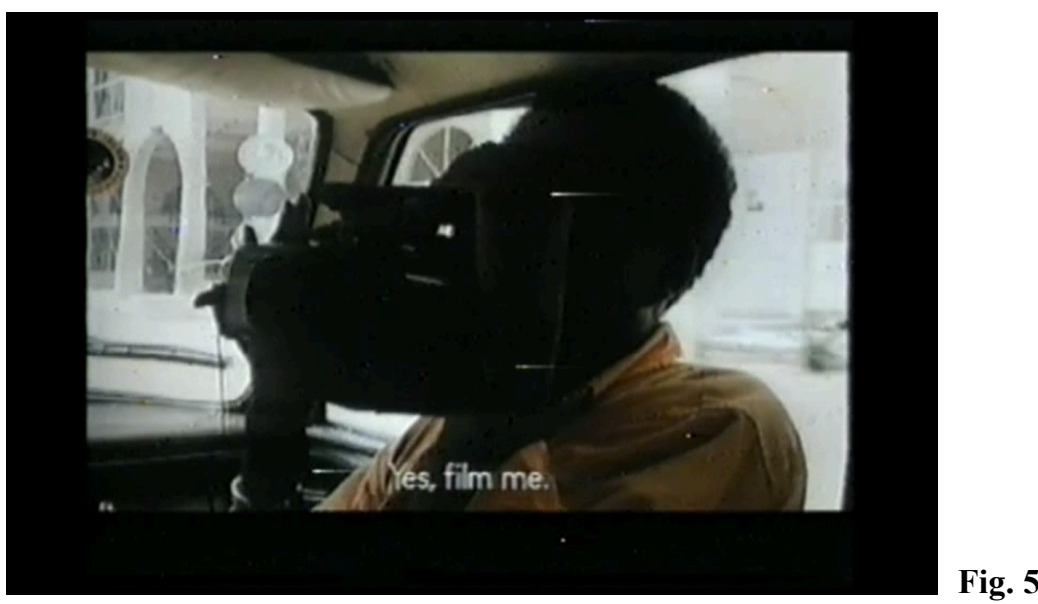

\footnotetext{
${ }^{60}$ The issue of gas smuggling in Chad is in fact one of the main subjects of Mahamat-Saleh Haroun's most recent film Grigris (2013).
} 


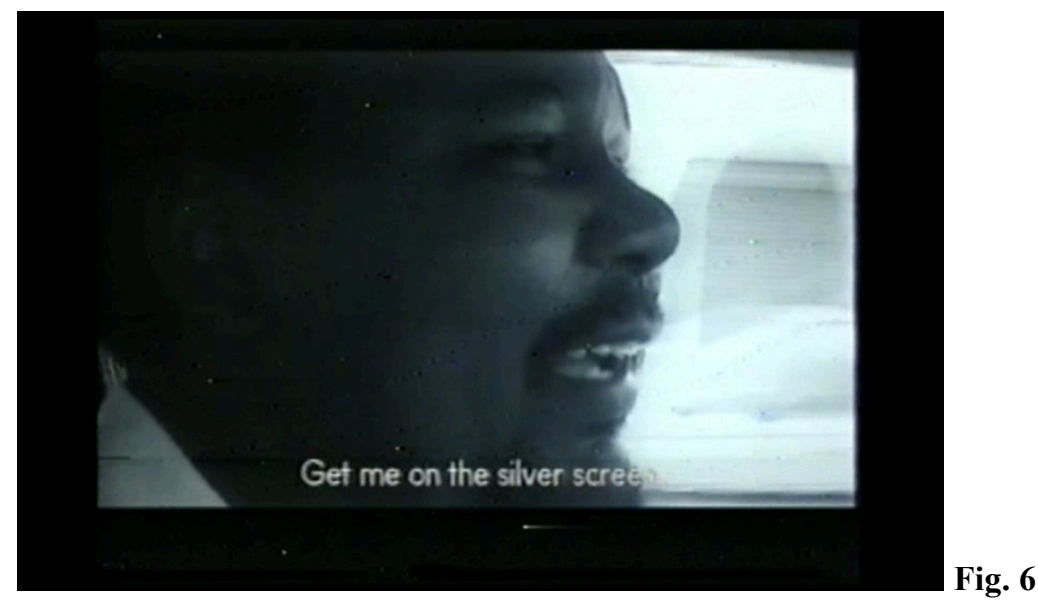

Beyond this thematic conclusion, the sequence with the cab driver demonstrates the film's performative strategy. The cab driver states his wish, which is immediately fulfilled; the spectator witnesses him on the "silver screen" at the very moment that he utters this desire. The film instantaneously describes and performs the action, which constitutes a performative gesture in the speech-act sense. Haroun's camera carries out this process, which situates him and his camera at the center of filmic creation. This and other sequences throughout the film remind us that Haroun's role in the film goes beyond being participatory; rather, that filming is inherently a performative act. This sequence also demonstrates that filming changes people's behavior, since the cab driver suddenly "performs" the role of cab driver; the act of filming changes his words and actions. Finally, this example, like the rest of the film's scenes that include the director, raises the question of who is holding the external camera. This formal, thematic, and political question is taken up in subsequent sequences, such as the one outside of the Sheherazade theater.

Whereas the example with the cab driver reveals Haroun in an uncomplicated relationship with his subject, another sequence presents him in a problematic relationship with what he films. This example also undermines the apparent distinction between the two cameras. Indeed, this sequence introduces incoherencies into the film's internal logic by revealing the film's means of production, a prevalent strategy in Stella Bruzzi's category of performative 
films. Films that deploy performative strategies seek "to accentuate, not mask, the means of production," she writes. ${ }^{61}$ Over the course of the film Haroun's camera is visible within the diegesis, while the external camera remains invisible to characters and spectators alike, in accordance with the conventions of narrative realism. However, the external camera makes its presence known in one moment. When the camera, along with other elements of the cinematic apparatus, appear in a film's diegesis, "they signal...that the narrative is not 'real' but made," states Linda Rugg. ${ }^{62}$ The presence of Haroun's camera makes the process of filmmaking apparent, while the viewer's awareness of the external camera heightens her sense that Bye Bye Africa is an artificial construction.

The following example occurs as Haroun finishes touring the Sheherazade, the final cinema on his itinerary. A long shot in color from the external camera focuses on the exterior of the theater as Haroun and Garba exit. It cuts to a closer image from behind Haroun as he peers into his camera's viewfinder (figure 7). The shot changes over to black-and-white footage from his perspective, examining a worn film poster for Ghulami, an Indian film (figure 8). Haroun

Fig. 7

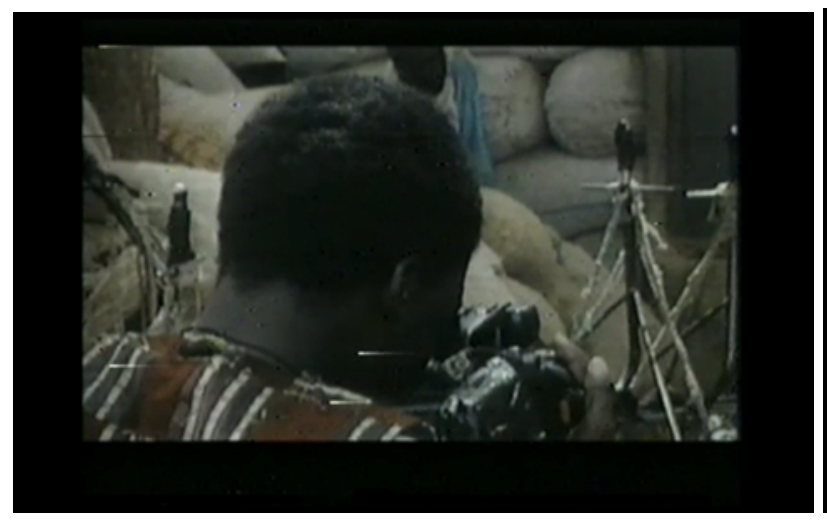

Fig. 8

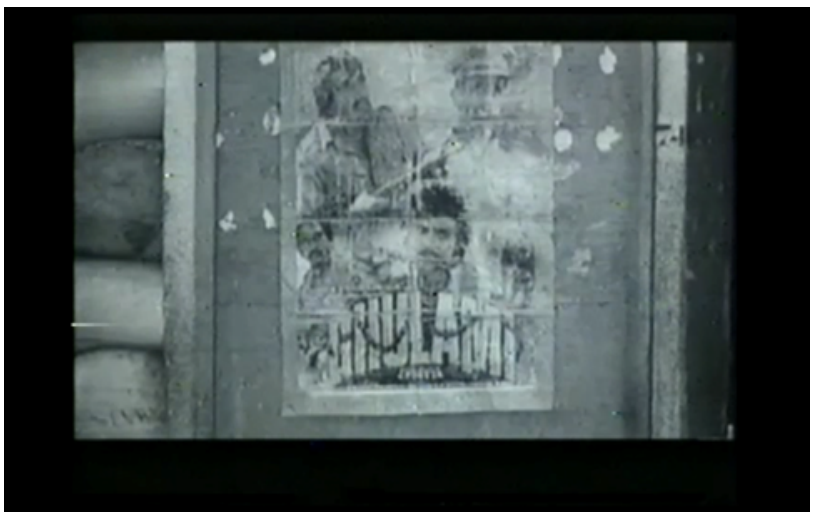

\footnotetext{
61 Bruzzi, New Documentary, 155.

${ }^{62}$ Rugg, Self-Projection, 141.
} 
pans the camera over the people milling outside the cinema entrance and focuses on a man who looks directly into the lens, waves his finger angrily and shouts at him (figure 9). He charges toward Haroun and forcefully knocks the camera from his face (figure 10). The shot brusquely

Fig. 9

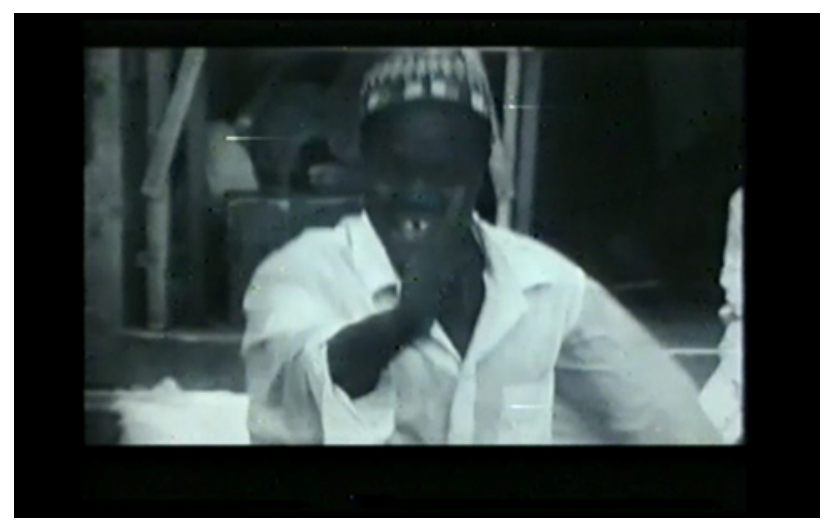

Fig. 10

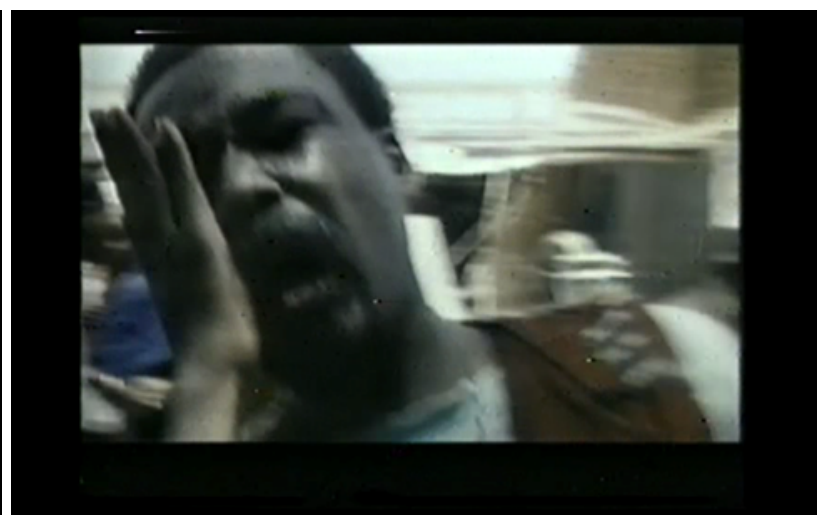

cuts to a side-angle shot from the external camera of Haroun who covers his face in pain. People gather around the commotion, including an elderly woman whose words are not translated in the subtitles, but whose wagging finger expresses her disapproval, a gesture that echoes the aggressor's both before and after the attack (figure 11). As does the aggressor a moment later, Fig. 11

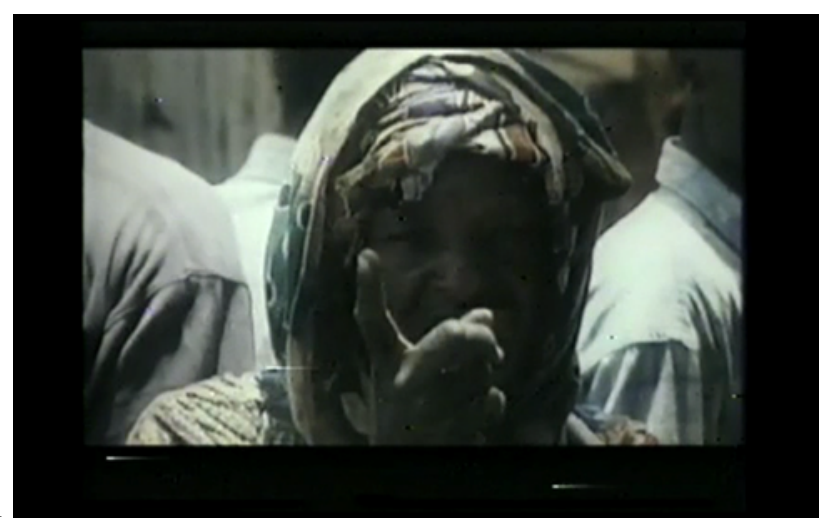

she breaks the fourth wall by looking at the camera and, by extension, the audience. The aggressor sits on the theater steps, clutching Haroun's camera; he states that by filming him, Haroun is stealing his image (figure 12). Coaxed by Garba to return the camera, the man approaches the external camera until he is in extreme close-up and, looking straight into the lens, 
says, "Tu sais ce que c'est voler l'image d'autrui? Tu as de la chance" (figure 13). ${ }^{63}$ Who is the object of this man's criticism, the "tu" toward which his resentment is aimed? Of course he directs his anger at Haroun, but he addresses the camera and, thus, speaks to the camera's operator who is neither Haroun nor Garba. While the identity of the person behind the camera remains a mystery, the viewer's awareness of the presence of this camera is inconsistent with its operative logic in the rest of the film (and the conventions of narrative realism).

Fig. 12

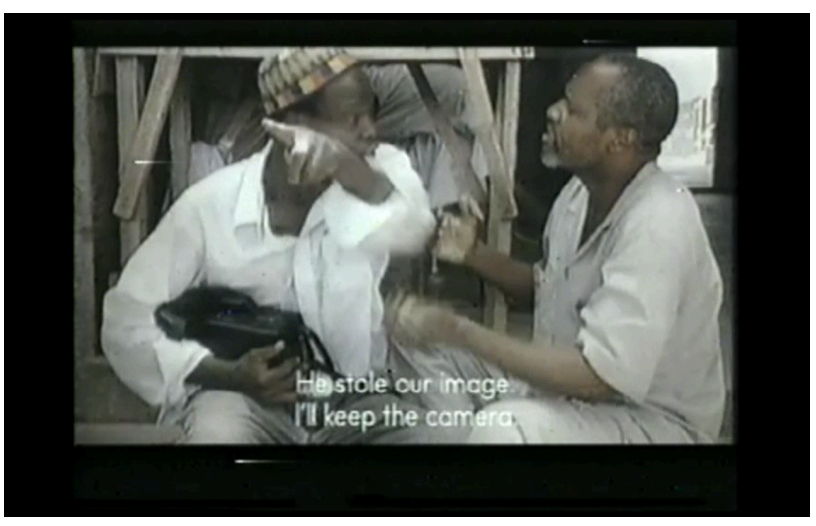

Fig. 13

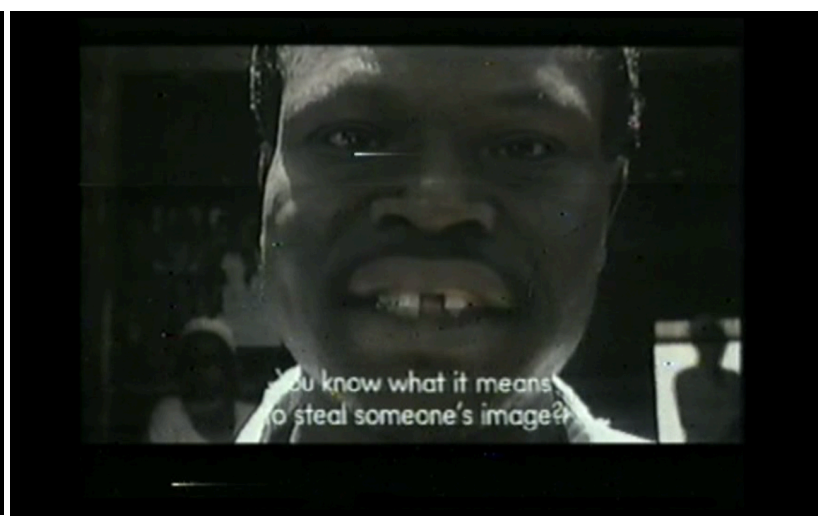

The above example stages a filmmaker seeking to capture "reality," and a subject who does not wish to be captured. The film thereby illustrates thematically and formally that filmmaking is a process of mediation and control of reality. Whereas the example of the cab driver introduces the theme of filming Chadians as they wish to be filmed, the man who strikes Haroun and then accuses both him and the operator of the external camera of stealing his image advances the idea by refusing to be filmed. It also implicates the spectator in the process of stealing and consuming images of Africans without their approval or control of the content. The film thus foregrounds the idea that representing Chadians against their wishes is an inherently violent gesture. This relates to Mahamat-Saleh Haroun's strategy of performing how not to make a film in Chad, and how to proceed. Further, breaking the fourth wall and revealing the presence

\footnotetext{
63 "You know what it means to steal someone's image? You are lucky."
} 
of the external camera is a gesture that accentuates the film's means of production. This demonstrates Mahamat-Saleh Haroun's understanding that masking its means of production is what Stella Bruzzi calls an "impossibly utopian" gesture in a context in which filmmaking is still coming into being. ${ }^{64}$

In addition to raising the idea of filming Chadians in a respectful and meaningful manner, the above example also "poses questions about the process of compiling images," as Bruzzi has pointed out in other contexts. ${ }^{65}$ The encounter between Haroun and the man who hits him is ostensibly an accidental event, one that apparently would not have occurred if Haroun were not there, or were not filming the man in the first place. By featuring "chance" events such as this alongside other events that are supposedly predetermined, Bye Bye Africa operates at the intersection between fiction and reality. It acknowledges that the film's circumstances, events, and encounters, regardless of their ties to the historical world, are a result of the negotiation between the filmmaker/camera and subject/reality. How people's behavior and reality are shaped by the presence of the filmmaker and the camera is a component of the film's broader reflection on the process of cinematic creation.

In a similar vein, Bye Bye Africa also touches on ethical questions involved in filming, especially through the story of Isabelle, the actress whose previous role as a character with AIDS leads her to become a social outcast, and prompts her suicide. Isabelle's family and community conflate her character's onscreen reality with actual reality, which irrevocably alters her life. When Haroun gives his camera to his nephew, Ali, at the end of the film, he acknowledges his

\footnotetext{
64 Bruzzi, New Documentary, 155.

65 Ibid., 122. Bruzzi discusses Patrick Keiller's London in the passage from which I am citing.
} 
awareness of the cinematic medium's potential to shape reality and the viewer's perspective of it by giving the following instructions: "Tu fais très attention à ce que tu vas filmer, hein?",66

Bye Bye Africa addresses and engages with issues associated with filmmaking in Africa, such as representing Africans in a certain manner, as the foregoing examples illustrate. Haroun indicates his desire to overcome these issues by performing how not to make a film in Chad, and also through two significant gestures. First, his character gives his camera to Ali, who represents the younger generation, and is also, importantly, someone who lives in Chad and thus remains connected to people and life there. These qualities suggest his ability to film Chadians and life in Chad in a meaningful way, and Haroun's request that he send him a tape every month implies his own wish to remain in closer contact with his native culture.

Additionally, Haroun burns the videocassette tape that contains the footage shot by his hand-held camera. Isabelle had previously confiscated Haroun's camera and recorded herself bidding a final goodbye before committing suicide. After retrieving his camera and watching the tape labeled "BYE BYE CASTING," Haroun sets it on fire. This establishes the inauthenticity of the image. The images from the tape, including the cast auditions for Haroun's film, Isabelle's suicide note, and any additional segments that this videocassette may contain, appear in the completed film, proving that it was not actually destroyed. This technique calls into question the status of documentary image as document, or evidence, and correlates to the film's refusal to achieve a straightforward relationship between filmmaker, image, and spectator. At the same time, burning the videocassette symbolically represents Haroun's move to transform filmmaking practices and to start anew.

66 "Be very careful about what you film, okay?" 


\section{Homage to the Act of Filming}

If Bye Bye Africa essentially shows how not to make a film in Chad, it also includes a short sequence that embodies Haroun's vision of filmmaking in its exploration of a subject that is meaningful to him on a personal level. It suggests a shift on Haroun's part, away from the detachment and alienation that characterizes him throughout the majority of the film, towards a "personal and intimate portrait of Africa [...] that speaks to anyone who watches it, inside or outside of Africa," as Oscherwitz writes. ${ }^{67}$ The sequence captures Haroun's grandmother as she slowly plods down the middle of the film's frame (figure 14). It is unclear who is filming,

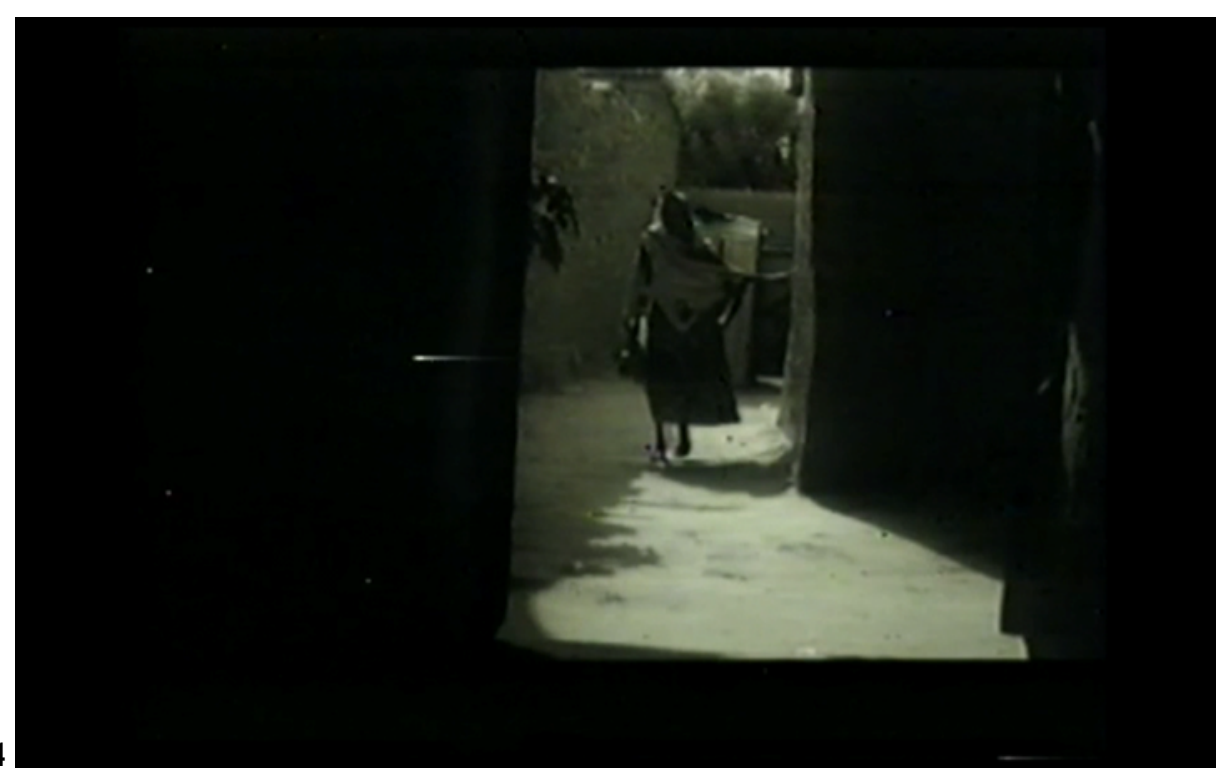

because it immediately follows the moment in which Haroun's character presents his camera to his nephew, Ali. The unobtrusive presence of the person filming further distinguishes this moment from the majority of the film. The image and sound are also distinct; unlike the rest of the sequences cast in either black and white or color, the image is sepia-toned. In voice-over Haroun's voice takes on a deeper pitch and slower pace as he speaks with deep veneration about

${ }^{67}$ Oscherwitz, "Bye Bye Hollywood," 258. 
his grandmother, the woman "who taught him how to tell stories." ${ }^{, 68}$ In a sense, this sequence constitutes what Kenneth Harrow calls in other contexts a sort of "praise-filming," or homage to this woman. ${ }^{69}$

It is precisely the idea of rendering homage that more fully connects this sequence to Mahamat-Saleh Haroun's narrative and aesthetic project in Bye Bye Africa, and also allows for a conclusion beyond a purely thematic one. In Kenneth Harrow's discussion of Djibril Diop Mambéty's Parlons Grand-mère, he identifies a narrative and aesthetic approach in Mambéty's filming that also applies to Haroun's project. Harrow writes, "what appears to be an homage to an old woman, Yaaba...is more an homage to the act of filming. ${ }^{, 70}$ In a similar vein, the above sequence in Bye Bye Africa clearly focuses on the grandmother, and yet the distinct qualities that separate it from the rest of the film, including the prominent multiple framings within the image, reveal a reflection on the act of filming itself. This strategy dovetails with the sequences focusing on the state of cinema in Chad, and applies more broadly to Mahamat-Saleh Haroun's project in Bye Bye Africa. While the film centers on making a film, the subject of that project matters little; rather, its significance lies in how it is being made, and also that it is being made in the first place.

In Bye Bye Africa, Mahamat-Saleh Haroun films, stages, shapes, and edits "reality" to draw the viewer's attention to the processes of filmmaking and its inherent challenges. The film's deliberate confusion of the layers of reality and representation reflect its particular sociohistorical context, Chad's nascent film industry. Like the performative documentaries in Bruzzi's

\footnotetext{
68 "Cette femme [...] qui m'a appris à raconter des histoires," is stated by the voice-over narrator.

${ }^{69}$ Kenneth Harrow, Postcolonial African Cinema: From Political Engagement to Postmodernism (Bloomington: Indiana University Press, 2007), 224. His example pertains to Djibril Diop Mambéty's Parlons Grand-mère (1989).

${ }^{70}$ Harrow, Postcolonial African Cinema, 218-19. Parlons Grand-mère (1989) is a film constructed from images taken of rehearsals for Idrissa Ouedraogo's Yaaba. Harrow skillfully describes it as "a film that is emotionally in harmony with the characters and sensibility of [Yaaba], and yet formally completely at odds with it" (ibid., 219).
} 
study, Bye Bye Africa does not disguise but accentuates its inherent instability. ${ }^{71}$ This reveals a fruitful tension between context of production and mode(s) of cinematic representation.

\section{Building a Tradition of Filmmaking in Chad}

The film's performative strategy extends beyond the world of filmmaking. Indeed, the performative role of this film not only created a tradition of filmmaking by and for Chadians, it also played a formative role in reshaping the situation of cinema in the country. For instance, since the film's release, the Normandie theater has been renovated and re-opened, an initiative that Chadian authorities attribute to Bye Bye Africa. ${ }^{72}$ Mahamat-Saleh Haroun has also opened a film school in the country. His activities as a sort of cultural diplomat in the realm of cinema are evident not only in examples with respect to Chad, but on a broader international level. From 2008 to 2010 he held the role of Director of Commission of Fonds Sud, a source of funding previously available to Africans and others from nations within France's sphere of cooperation. ${ }^{73}$ As Bye Bye Africa demonstrates and these anecdotes suggest, Haroun's engagement with Chadian and African cinema posit a new role for the African filmmaker.

When Bye Bye Africa had its premiere in N'Djamena, many Chadians from Gardolé, the city's neighborhood where Mahamat-Saleh Haroun used to live and in which the film is set, came to the theater. Haroun recounts that they were still waiting at the door even after the film started playing. When he approached them, they explained that they wanted to see the show but

\footnotetext{
${ }^{71}$ Bruzzi, New Documentary, 155.

72 “A Ndjamena, la réouverture du Normandie.” France Culture, November 1, 2011, http://www.franceculture.fr /2011-01-11-a-n-djamena-la-reouverture-du-normandie.html.

${ }^{73}$ Teresa Hoefert de Turégano, African Cinema and Europe: Close-up on Burkina Faso (Florence, Italy: European Press Academic Publishing, 2004), 92-93. This "intraministerial fund" was created by the Ministry of Foreign Affairs, the Ministry of Cooperation and Development, and the Ministry of Culture and Francophony in 1984. On December 31, 2011, the Fonds Sud was subsumed by the CNC's grant program L'Aide aux cinémas du monde.
} 
could not pay to enter. Haroun had to pay for them to get in. ${ }^{74}$ Since then, Haroun has adapted to his compatriots' economic needs and also the prevailing exhibition format by premiering his new films at video clubs. ${ }^{75}$ The desire to reach local audiences, and concern with the structures of film exhibition and distribution, are topics that receive more attention in the Cameroonian filmmaker Jean-Marie Teno’s documentary, Lieux Saints.

In Lieux Saints, Jean-Marie Teno also makes his authorship explicit, but in a different way from Haroun in Bye Bye Africa. The film's director and author of the voice-over text, Teno also provides voice-over narration (in the first person), interacts with the film's interviewees from behind the camera, and appears on-screen at one moment by presenting his film Chef! at the local video club. Teno's multiple roles obfuscate the line between off- and on-screen presence, director/originator of the film's vision and character/actor. The director fulfilling a multiplicity of roles lends to the film's performative strategies in the sense of Bill Nichols' approach to the mode. Performative documentary, as outlined by Nichols, adopts a personal, engaged point of view, and treats knowledge as embodied, affective, and situated. ${ }^{76}$ In Lieux Saints the filmmaker's voice-over narration organizes the film, and employs introspective forms of speech, techniques that are characteristic of performative documentary according to Nichols' approach. His approach helps explain how the filmmaker's perspective and voice give shape to the film, while Stella Bruzzi's concept of the performative in the speech-act sense sheds light on the film's larger project. Lieux Saints foregrounds the problems facing African film, and it also enacts a solution by depicting the interrelationship between cinema and other art forms; it thereby puts into practice a mode of representation that seeks to resolve the issues that it names.

\footnotetext{
${ }^{74}$ Stuart Jeffries, “Out of Africa,” The Guardian, November 14, 2002, http://www.theguardian.com/culture/2002 /nov/15/artsfeatures3.

${ }^{75}$ Angela Dalle Vacche, "A Film is Trying to Build a Sort of Eternity: An Interview with Mahamet - Saleh Haroun," Senses of Cinema 47 (May 2008), http://sensesofcinema.com/2008/feature-articles/mahamet-saleh-haroun/.

${ }^{76}$ Nichols, Introduction to Documentary, 210.
} 


\section{Lieux Saints (Sacred Places, 2009)}

At the turn of the new millennium, Jean-Marie Teno put forth a profound metaphor: he said he was convinced that African filmmakers are invisible. ${ }^{77}$ As Alain Patrice Nganang writes, Teno "understood this metaphor of invisibility in relation to [...] the absence of his point of view as an African filmmaker on the global scene of representations. ${ }^{, 78}$ Less than a decade after making this statement, Teno's latest film Lieux Saints shifts the idea to explore the invisibility of African films on the continent. This film's focus is distinctively different from the subjects explored in his previous films, which spotlight the complexities and ironies of colonial and postcolonial relations; his titles include Clando (1996), Chef! (1999), Vacances au pays (2000), and Le malentendu colonial (2004). Teno came to prominence in the 1990s with his documentary, Afrique, je te plumerai (1992), which "garnered him widespread awards and attention, quickly becoming a staple in films festivals and classrooms," as Michael Martin and Marissa Moorman write. ${ }^{79}$ In addition to exploring distinct subject matter, Lieux Saints also sheds the rigorous criticism characteristic of Teno's other works as it reflects on the present state of African cinema in a specific locale in Ouagadougou, Burkina Faso. The film takes place during the 2007 gathering of FESPACO in one of the city's few remaining "quartiers populaires," Saint Léon. ${ }^{80}$ Its inhabitants cannot attend the festival nor do they have access to the films shown. ${ }^{81}$ As Carmela Garritano observes, the neighborhood functions as "a metonym for

\footnotetext{
${ }^{77}$ In Alain Patrice Nganang, "Deconstructing Authority in Cinema: Jean-Marie Teno," in Cinema and Social Discourse in Cameroon, ed. Alexie Tcheuyap (Bayreuth: Thielmann \& Breitinger, 2005), 145. Teno made this statement while introducing his film Vacances au pays during the Berlinale in 2000.

${ }^{78}$ Ibid., 145-46.

79 Martin and Moorman, "The Civilising Mission of Globalisation," 64.

${ }^{80}$ Stated by the narrator in voice-over.

${ }^{81}$ The Cinéma Numérique Ambulant (CNA), a mobile cinema that offers free screenings in the less central neighborhoods and rural areas, likely travels to Saint Léon, however there is no mention of it in the film. The CNA has been in existence since 2001, and has its headquarters in Ouagadougou.
} 
ordinary Africans who have no access to serious African cinema." ${ }^{\$ 2}$ Indeed, the film highlights factors that limit the consumption of African films, while it also foregrounds art as a natural occurrence within the community by following a video-club owner, a djembe player, and a writer. The film's attention to these individuals and the interactions of their endeavors in the cultural milieu of Saint Léon reflects Teno's overarching interest in assessing the state of African cinema and his role as a filmmaker. In his film's thematic and formal attention to these three individuals, Teno draws connections to cinema and shows that, as Jude Akudinobi has written in other contexts, "African cultural life contains intrinsic and complex mechanisms for regeneration. ${ }^{, 83}$

While references to le cinéma africain in broad terms abound in Lieux Saints, here the label specifically refers to the tradition of celluloid art film centered in French-speaking subSaharan Africa. As Ralph Austen and Mahir Şaul note, films of this kind are often identified with FESPACO ${ }^{84}$ The primary reasons for this are the French government's investment in cinema from the region, which fostered the growth of art cinema or a cinéma d'auteur above any other types of cinema, and the fact that up until recently films eligible for the grand prize at FESPACO were restricted to celluloid formats. ${ }^{85}$ Accordingly, references to "African" film in Lieux Saints' voice-over narration and dialogue imply art cinema from the Francophone West African region as opposed to "popular" or commercial formulas. Thus, in seeking to define the future of cinema, Teno's film does not consider adopting, nor does it mention, the video-movie model that industries in Nigeria (such as Nollywood), Ghana, and other countries across the continent have

\footnotetext{
82 Carmela Garritano, African Video Movies and Global Desires: A Ghanaian History (Athens, OH: Ohio University Press, 2013), 196.

83 Jude Akudinobi, "Tradition/Modernity and the Discourse of African Cinema," Iris 18 (1995), 27.

84 Ralph A. Austen and Mahir Şaul, eds., Viewing African Cinema in the Twenty-First Century: Art Films and the Nollywood Video Revolution (Athens, OH: Ohio University Press, 2010), 1.

${ }^{85}$ The debate over medium came to a head in 2013. I discussed this briefly in Chapter 2.
} 
made highly successful over the past decade. ${ }^{86}$ Rather, Teno grounds his film's quest in the tradition of filmmaking of which he is part. As a result, Carmela Garritano argues, “while Teno’s documentary is critical of the barriers that shut ordinary Africans out of FESPACO, Sacred Places enacts a similar exclusiveness, discounting locally made and watched movies."

Garritano's question as to why the documentary does not raise the topic of Nollywood (or, more generally, African popular movies) is valid, since, as Kenneth Harrow succinctly puts it, 'Nollywood...is the answer to African culture's quest for a viable economic basis that rests upon an African audience and its taste." ${ }^{88}$ However, I agree with Anjali Prabhu, who states with respect to Lieux Saints as well as other recent African documentaries, "it is perhaps too soon to write off certain films as highbrow or elitist." ${ }^{89}$ Indeed, as this chapter section elucidates, the film's narrative and aesthetic strategy can productively be read not only as an effort to envision, but also as an enactment of new creative possibilities for African cinema.

Lieux Saints follows three individuals whose respective crafts represent the basic components of cinema: Bouba, the ciné-club owner, represents image; Jules César, the djembemaker and player, represents sound; and Abbo, the writer, alludes to the medium's written forms, such as the treatment, script, narration, and on-screen text. Through their respective mediums and activities, each individual parallels the filmmaker and his craft, to some degree; they are "à l'image du cinéaste et de son interrogation," as Olivier Barlet skillfully notes. ${ }^{90}$ At the same time, the film's focus on the three subjects also reveals deficiencies in the filmmaker and his practices,

\footnotetext{
${ }^{86}$ For a discussion of the video-movie phenomenon, see the Introduction.

${ }^{87}$ Garritano, African Video Movies and Global Desires, 197.

${ }^{88}$ Kenneth Harrow, Trash: African Cinema From Below (Bloomington: Indiana University Press, 2013$), 6$.

${ }^{89}$ Anjali Prabhu, Contemporary Cinema of Africa and the Diaspora (West Sussex, UK: Wiley Blackwell, 2014), 158. In her discussion of this claim, Prabhu writes that Teno and other African documentary filmmakers use documentary to question modernity as part of her book's larger argument that African cinema participates in what she calls the "Africanization" of the spectator.

90 Olivier Barlet, Les cinémas d'Afrique des années 2000: Perspectives critiques (Paris: L'Harmattan, 2012 ), 167.
} 
given Lieux Saints' premise, “African cinema's demise." ${ }^{91}$ The film's attention to the ciné-club owner and his establishment highlights the integration of art into daily life. Focus on the writer and djembe player also stresses this point, while the additional use of formal techniques bring cinema and these art forms into creative dialogue.

My analysis of Lieux Saints builds upon Justin Izzo's study, in which he posits the notion of "cinematic kinship" as "a form of 'documentary consciousness' (to borrow from Vivian Sobchack's phenomenological phrase [1999:241]) [...] that emphasizes how nonfiction cinema creatively experiences its proximity to other artistic forms." ${ }^{92}$ Izzo focuses on Vacances au pays and Lieux Saints and argues that the shift that occurs in each film's engagement with modernity "charts transformations in the filmmaker's relationship to his own medium and other artistic forms. ${ }^{.93} \mathrm{He}$ concludes that, contrasting with Vacances au pays, the authority of the filmmakeras-storyteller in Lieux Saints "appears radically diluted, in constant contact with other art forms that have their own stories to tell. ${ }^{, 94}$ Thus, he argues, the filmmaker's role "is to demonstrate that these processes of dilution actually open up creative possibilities for cinematic storytelling and do not threaten cinema's aesthetic prerogative." ${ }^{95}$ While highly insightful, Izzo's study overlooks many formal strategies the film deploys to "experience proximity" with other art forms, as well as the notion of transmission, which is at the heart of Teno's project.

Transmission, as it pertains to African cinema, is the ability to reach African audiences with African films, but currently distribution and exhibition infrastructure cannot support it. In addition to the idea of making films, or art, available in a practical sense, transmission also indicates an ongoing tradition of filmmaking-that is, the ability to impart to the next generation

\footnotetext{
${ }^{91}$ Martin and Moorman, "The Civilising Mission of Globalisation," 64.

92 Izzo, “Jean-Marie Teno's Documentary Modernity," 41.

93 Ibid., 51.

94 Ibid.

95 Ibid.
} 
of filmmakers an assortment of practical tools, methods, and wisdom. In an essay he published after Lieux Saints' release, Jean-Marie Teno highlights the lack of policies to support filmmaking both within and among countries as one of the recurring problems of cinema on the continent. He writes:

filmmakers rarely have time for anything other than their own daily struggle to create and survive. This does not nurture filiations or long-time collaboration between filmmakers of different generations. Each generation is thus left to fend for itself and each new generation acts like it thinks it has reinvented the wheel! ${ }^{96}$

With the transmission of African films and methods of filmmaking being complicated by a number of factors, Lieux Saints invokes the past of African cinema and specifically the notion of the griot. In the film's rhetoric, implicit and explicit references to the griot denote the idea of transmission.

Historically, the complex figure of the griot was a historian, storyteller, or praise-singer, among many other possible functions. ${ }^{97}$ More generally, "a griot can be anybody in the society who transmits messages to the people," Nwachukwu Frank Ukadike writes. ${ }^{98}$ The interrelationship between the role of the African filmmaker and the griot was a parallel initially drawn by Ousmane Sembène who, in 1978, defined his profession as a filmmaker in relation to the griot's: "Le cinéaste africain est comme le griot, qui ressemble au troubadour du MoyenAge: un homme de savoir et de bon sens, qui est l'historien, le raconteur, la mémoire vivante et

\footnotetext{
96 Jean-Marie Teno, "Writing on Walls: Documentary, the Future of African Cinema?," Africultures (March 2010), http://www.africultures.com/php/?nav=article\&no=10003.

97 Thomas Hale chronicles the griot's numerous functions, a list he deems to be "both extraordinary and incomplete," 57. Thomas Hale, Griots and Griottes: Masters of Words and Music (Bloomington: Indiana University Press, 1998).

${ }^{98}$ Nwachukwu Frank Ukadike, Black African Cinema (Berkeley: University of California Press, 1994), 206.
} 
la conscience de son peuple." ${ }^{.99}$ Additionally, Djibril Diop Mambéty and Adama Drabo described their role as that of the "modern griot." ${ }^{\prime 100}$ As the keeper and transmitter of oral tradition, the griot's influence has led many filmmakers to deploy structural and stylistic elements reminiscent of West African oral narrative forms in their films. ${ }^{101}$ Teno's own familiarity with and inclusion of oral narrative forms is evident in his previous films, such as Clando (1996). ${ }^{102}$

In Lieux Saints, the evocation of the previous generation of African filmmakers-the 'ancestral' figures who positioned themselves as cinematic griots-generates questions about the future of filmmaking on the continent. Filmmakers such as Djibril Diop Mambéty have adopted the griot's techniques so as to address the future. Indeed, in his definition of the term, Mambéty displays a strong sense of futurity: "Griot est le mot qui convient à ce que je fais et au rôle que le cinéaste joue dans la société...Plus qu'un conteur, le griot est le messager de son temps, un visionnaire et le créateur du futur." ${ }^{103}$ Thackway highlights how drawing inspiration from the griot's technique prompts filmmakers to "interrogate the past in order to reflect upon and to forge the present and the future." ${ }^{\prime 104}$ Olivier Barlet similarly observes the corresponding techniques between the griot and the filmmaker. "In giving life to the word," he writes, filmmakers "contribute to the invention of a future for the people to whom they feel

\footnotetext{
99 "The African filmmaker is like the griot who is similar to the European medieval minstrel: a man of learning and common sense who is the historian, the raconteur, the living memory and the conscience of his people." Translation in David Murphy and Patrick Williams, Postcolonial African Cinema: Ten Directors (Manchester: Manchester University Press, 2007), 8.

100 Thackway, Africa Shoots Back, 58.

101 This approach is particularly evident in "return to the source" films (which I discussed in my previous chapter), and in films dealing with history, notes Thackway, 58. In more recent studies, Alison J. Murray Levine's article demonstrates that Bamako contains structural and stylistic links to orality and oral performance. Levine, "Words on Trial: Oral Performance in Abderrahmane Sissako's Bamako," Studies in French Cinema 12, no. 2 (2012): 151-167. 102 The film allegorizes a Cameroonian expatriate's hardships in Germany with a hunter tale. The tale's allegorical nature is characteristic of how allegory functions in oral narrative forms, and also the fragmented delivery of the tale with its willful ambiguity regarding who's narrating echoes the traditional genre. Thackway, Africa Shoots Back, 68 . 103 "The word griot is the word for what I do and the role that the filmmaker has in society... beyond being a storyteller, the griot is a messenger of one's time, a visionary and the creator of the future." Translation in Thackway, Africa Shoots Back, 58.

${ }^{104}$ Thackway, Africa Shoots Back, 58.
} 
committed." ${ }^{, 105}$ If the griot "had the duty of simultaneously recalling the past, honouring the present, and, to a lesser extent, imagining the future," filmmakers from Sembène onwards were committed to the future. ${ }^{106}$

Evoking the past as a means of evaluating the present and considering the future is a characteristic of Teno's film style, observes Anjali Prabhu. ${ }^{107}$ This stylistic and structural approach is evident in Afrique, je te plumerai, which situates 'official' history alongside personal memory in an attempt to offer "une lecture de l'histoire du Cameroun du point de vue de l'indigène." ${ }^{108}$ Afrique reveals the continuing foreign domination of cultural production on the market in postcolonial Cameroon and by extension, Africa, through the example of books. The film shows that technical resources to print books are not lacking, and yet the availability of books by African authors is scarce. Lieux Saints shifts the spotlight to the situation regarding African cinema. As with literary production in Afrique, films are being made, but issues with distribution and exhibition make it almost impossible for African audiences to watch them. In its focus on access to local cultural production, or lack thereof, Lieux Saints is an extension of Teno's project in Afrique. While the subject shifts to the possible disappearance of African cinema on the continent, the larger stakes remain the preservation and transmission of culture through artistic forms.

\footnotetext{
105 Olivier Barlet, African Cinemas: Decolonizing the Gaze, trans. Chris Turner (London: Zed Books, 2000), 164-65.

106 Although Lieux Saints contains explicit references to the griot, it is worth noting that analyzing elements reminiscent of the griot and oral forms in a film from a West African director runs the risk of reductionism, as scholars such as Valérie Thiers-Thiam have argued. See Thiers-Thiam, A chacun son griot: le mythe du griotnarrateur dans la littérature et le cinéma d'Afrique de l'Ouest (Paris: L'Harmattan, 2005), pages 9-11. In her article on Bamako, Alison Levine also identifies the various problems involved in "any attempt to identify the thematic and formal relationship with oral performance in a film that is in some way connected to the African continent." Levine, "Words on Trial," 153-54.

${ }^{107}$ Prabhu, Contemporary Cinema of Africa and the Diaspora (West Sussex: Wiley Blackwell, 2014), 188.

108 "An indigenous reading of Cameroonian history." This quotation comes from Teno's voice-over in the film. Afrique, je te plumerai, directed by Jean-Marie Teno (San Francisco, CA: California Newsreel, 1992), DVD.
} 


\section{Art and Daily Life}

Lieux Saints shows art to be a natural occurrence in Saint Léon, a topic that reflects Teno's overarching question of how to overcome the issues separating African cinema and its audiences. In her foundational work on popular art forms and audiences in Africa, Karin Barber shows that there are especially porous boundaries between production and reception in many African contexts. ${ }^{109}$ Despite the "obvious cultural heterogeneity" of such a vast geographic area, Melissa Thackway writes that in most Francophone African cultures, "art forms are traditionally destined for the whole community, irrespective of status or lifestyle, and frequently play a functional role." ${ }^{110}$ Art forms, she continues, such as "music, song, dance, and orature are totally integrated into and related to people's daily existence."111 In fact, there is no word for "art" in the Wolof language, a famous remark made by Ousmane Sembène. ${ }^{112}$ In a similar vein, Teno states in an interview that in "popular African culture, the artist had a particular role not unlike the musician who performed at ceremonies; it was an occupation.",113

Lieux Saints illustrates the seamless integration of various art forms into the everyday by tracking the production of local goods for local consumption. The camera often roves through the neighborhood's main street, where craftsmen and manual laborers work alongside merchants, street vendors, and people engaged in leisurely activities. Images in medium and close range feature a young man engraving silver bracelets, surrounded by other workers similarly crouched over pieces of jewelry (figure 15). Numerous shots such as these, focusing on artisans and individuals involved in their work, establishes the theme of meaningful creation in a local

\footnotetext{
${ }^{109}$ Karin Barber, "Popular Arts in Africa," African Studies Review 30, no. 3 (Sept. 1978): 1-78.

110 Melissa Thackway, "Exile and the 'Burden of Representation': Trends in Contemporary Sub-Saharan Francophone African Filmmaking," Black Camera 5, no. 2 (Spring 2014), 8; Thackway, Africa Shoots Back, 52.

111 Thackway, Africa Shoots Back, 52.

112 In Lindiwe Dovey, Curating Africa in the Age of Film Festivals, 90.

113 Martin and Moorman, "The Civilising Mission of Globalisation," 64.
} 
context. Artisanal work or physical labor on goods that are destined for, and consumed by, the local community provides a counterpoint to the contemporary situation of Francophone West African filmmakers who struggle to connect with their audiences.

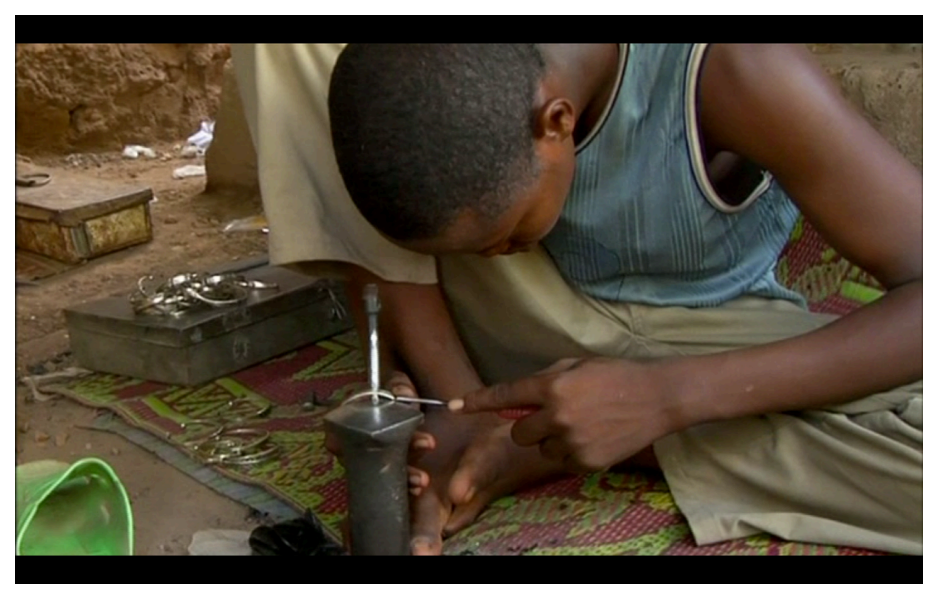

Fig. 15

Focus on the role of art and the artist in daily life in Saint Léon also evokes discourse about the function of African cinema. Indeed, the understanding of the arts as an integral part of daily life relates to the socio-educational role of cinema in the Francophone West African region, according to Thackway. ${ }^{114}$ She writes, "endogenous beliefs of the role of the arts and the artist in many sub-Saharan African cultures" undoubtedly allowed the "politically committed, socially responsible approach to filmmaking to achieve such enduring resonance. ${ }^{, 15}$ References to the "pioneers" who adopted this approach to filmmaking bookend the film. In the opening passage in voice-over, the narrator (voiced by Teno) highlights Ouagadougou as a central place for discussion and debate about African cinema at FESPACO, and asks: "que reste-t-il du rêve des pionniers qui voyaient dans le cinéma un outil de divertissement et d'éducation des masses?"116 The qualities cited, entertainment and didacticism, evoke Sembène's concept of cinema as an école du soir that contributes to the cultural and political education of his people. Questioning

\footnotetext{
114 Thackway, "Exile and the 'Burden of Representation," 8.

115 Ibid.

116 "What remains of the pioneers' dream, who saw cinema as a didactic tool as well as a form of entertainment for the masses?" All translations from the film's dialogue are mine.
} 
the legacy of early African filmmakers and by extension, its institutions (such as FESPACO and FEPACI), becomes a shadow topic throughout the film until it resurfaces at the end. ${ }^{117}$ The last frames feature quotes by Sembène and then Mambéty in white text against a black screen. In each quote, they highlight parallels between their roles as filmmakers and the griot (both are cited above).

\section{Movies and Daily Life}

While the narrator's question about early African filmmakers and their legacy lingers, the film follows the local video club in Saint Léon to investigate the place of cinema in a contemporary, working class African setting. Attending the few remaining larger movie complexes is often beyond the means of the poor, whereas the ciné-club brings them movies at an affordable cost (about the equivalent of ten cents). The video-club model, an establishment "run by locals under makeshift conditions and often using pirated DVDs," is a widespread phenomenon. ${ }^{118}$ It provides a third alternative to what Olivier Barlet terms "two opposing circles," which are comprised of "private cinemas geared toward the film festivals and upscale clientele" in the first circle, and "privatized theaters that had once belonged to governmentowned cinema company SONACIB" that are in rapid disappearance. ${ }^{119}$ A lifelong cinephile, Bouba (Nanema Boubacar), the owner, explains to the camera that he discovered the concept while on vacation in neighboring Côte d'Ivoire in 1990. Even if he is generally unable to make a

\footnotetext{
${ }^{117}$ An association of filmmakers, the Fédération PanAfricaine des Cinéastes (FEPACI) was "central to the inception as well as the ideological and foundational discourse of African films," Alexie Tcheuyap writes. Alexie Tcheuyap, Postnationalist African Cinemas (Manchester: Manchester University Press, 2011), 4.

118 Sheila Petty, "Sacred Places and Arlit: Deuxième Paris: Reterritorialization in African Documentary Films," Nka: Journal of Contemporary African Art 32 (Spring 2013), 74.

119 Petty, "Sacred Places and Arlit: Deuxième Paris," 74. SONACIB, or la Société nationale d'exploitation cinématographique du Burkina.
} 
profit, he sells enough tickets to get by, which he claims is "une dignité pour nous." ${ }^{120}$ Numerous shots of the ciné-club's exterior throughout the film situate it in a central location in Saint Léon. The image that frames the doorway frequently reappears throughout the film; the open doorway, arrows and pronoun votre highlight the establishment as an open, inviting place (figure 16).

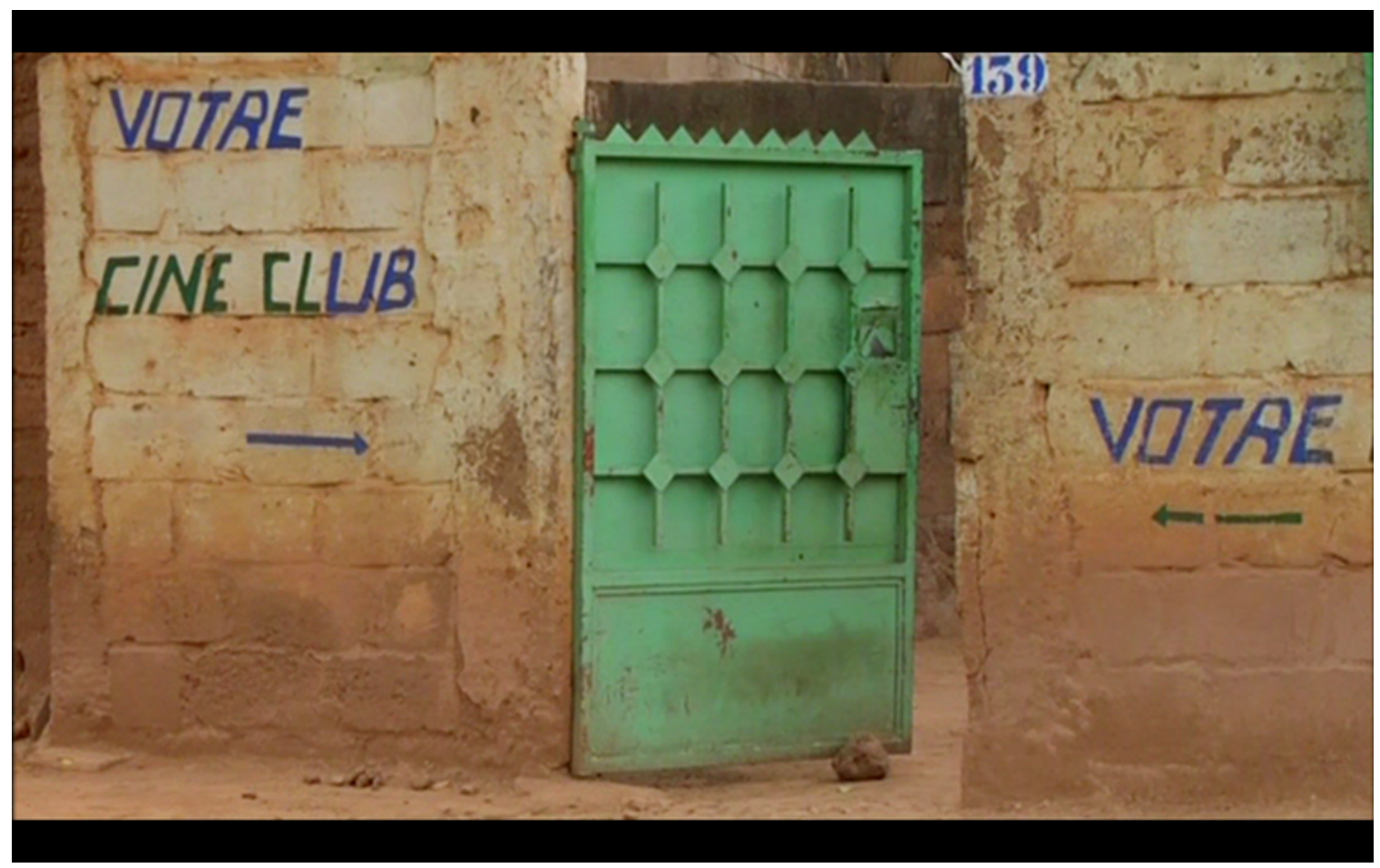

Fig. 16

Moviegoers, potential clients, and passersby examine Bouba's hand-written signs listing show times, an indicator of local interest in his operation (figures 17 and 18). Indeed, his ciné-club is a frequented spot that draws in people of all ages. In addition to showing movies, it regularly shifts functions, as Bouba invites other practicing Muslims to use his space for their daily prayers.

Doubling as a place of worship-a lieu saint, to borrow from the film's title-infuses the ciné-club with added meaning and significance to the lives of people in Saint Léon. Indeed, “it is the club's multiple incarnations that signify its vitality," as Martin and Moorman write. ${ }^{121}$

\footnotetext{
120 He claims that "this gives us a sense of dignity/pride."

121 Martin and Moorman, "The Civilising Mission of Globalisation," 64.
} 


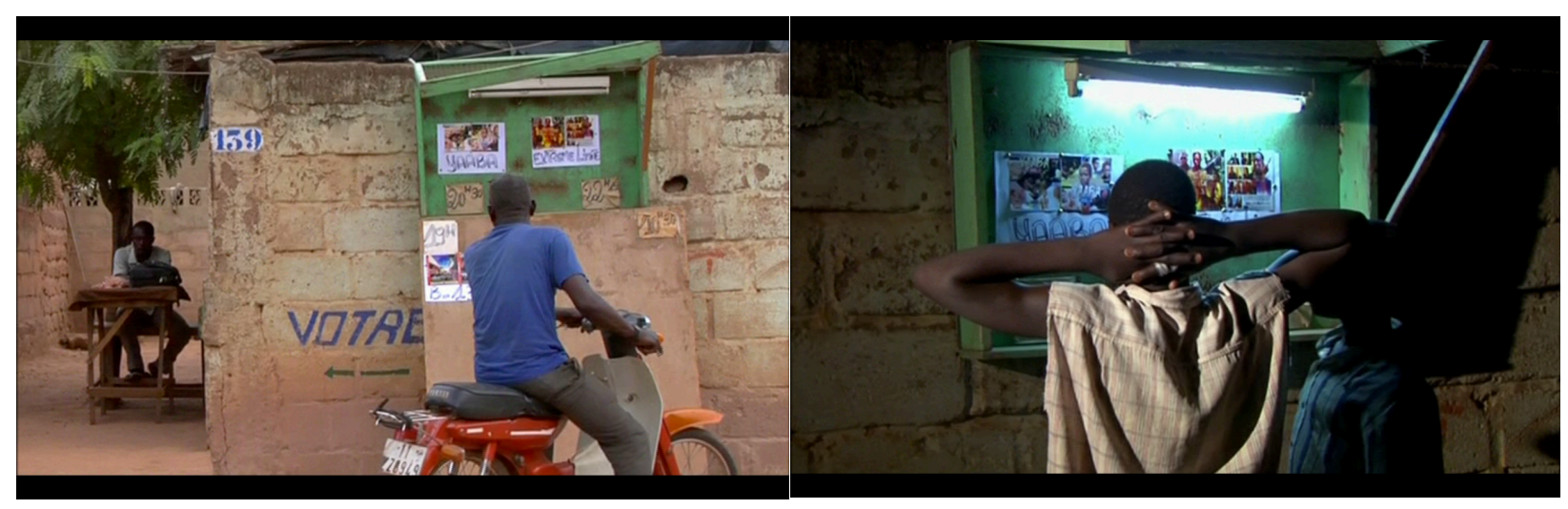

While the film highlights the ciné-club as an important cultural space that connects to people's daily existence, it emphasizes a crucial component that it lacks: African films. Bouba's clients, whom he refers to amicably as "mes cinéphiles," love African films: "Même ici, dans le ghetto...tout le monde veut voir des films africains," he states to the camera. ${ }^{122}$ Brief interviews with a few inhabitants of Saint Léon near the film's beginning confirm that these "audiences are thirsty to see films about themselves," as Prabhu writes. ${ }^{123}$ African films contain their history, culture, traditions, stories, and actors, and they give youth the chance to "voir autre chose que la routine," Bouba explains. ${ }^{124}$ However, he rarely shows them due to their very limited distribution and high cost, as opposed to the affordability and availability of pirated Hollywood, Bollywood, European, and Asian martial arts movies, movies that mostly comprise the ciné-club's program. Lieux Saints captures one exception, which is noteworthy not only for its singularity but also for the fact that it involves a title by a Burkinabe director. Bouba discovers a copy of Idrissa Ouedraogo's Yaaba (1989) as he flips through stacks of pirated DVDs provided by a local vendor. "Les cinéphiles sont gâtés ce soir," he exclaims, an observation that proves to be true in

\footnotetext{
122 "Even here, in the ghetto...everyone wants to see African films."

${ }^{123}$ Prabhu, Contemporary Cinema of Africa, 158.

124 "To see something besides their routine."
} 
the next sequence, which captures the audiences' laughter and deep enjoyment of the film. ${ }^{125}$ Despite the sizeable crowd, Bouba does not make enough to cover the cost of the rental. He counts the money before the camera, which emphasizes the financial challenge in screening an African film. For Bouba, the onus is on African filmmakers and producers to attempt to work with the local market.

If the film highlights the paradoxical situation between African filmmakers and audiences on the side of the local market (Bouba's video club), it also explores the situation from the standpoint of filmmakers. The filmmaker (Teno's character) interviews Idrissa Ouedraogo after the showing of Yaaba at the ciné-club. Located in the business district of the city, Ouedraogo's office is decorated with posters of his films. Close shots linger on the images of Yaaba and Tilai that appear flat and lifeless, a reminder that these and other African films remain, like the posters, tucked away and mostly out of reach of working-class African audiences. The filmmaker does not speak during the interview; rather, he lets Ouedraogo discuss his ideas on the issue of film distribution. Ouedraogo acknowledges that the growing number of establishments like Bouba's evinces a potential market, but subsidies keep him from pursuing these avenues, as they largely outweigh the insignificant earnings that would come from any involvement with the local economy. Conversely, he points out, the small-scale distributor, such as the one who supplies the video club, has discovered how to make "l'aspect culturel" compatible with "l'aspect économique." ${ }^{\prime 26}$ The narrator recounts a story in voice-over at the end of the film that summarizes the paradox that Ouedraogo highlights in this scene: it is about a guy who wants to have a child with his beloved without ever touching her. In other words, the African filmmaker wants Africans to see his films but will not, or cannot, do what he must in order for that to be

\footnotetext{
125 "The cinephiles/spectators are going to be spoiled tonight."

${ }^{126}$ Somewhat surprisingly, Ouedraogo makes no mention of the example of video-makers in West Africa (and other parts of the continent) who have created a model for reaching local audiences, nor does Teno elsewhere in the film.
} 
possible. Even though this story indicates that the situation between filmmakers and audiences remains unresolved, Lieux Saints places film and the filmmaker at the center of the process of working towards a solution.

At first glance, the sequences with the writer and djembe musician may seem to simply connect to and reinforce the interrelationship between art and daily life. However, the film's particular thematic and formal attention to each individual elicits significant parallels with the filmmaker and his quest; they are "à l'image du cinéaste et de son interrogation," as Barlet aptly notes. ${ }^{127}$ The filmmaker does not step into the frame during his encounters with the writer and djembe musician, and only verbally interacts with the latter. And yet, his presence is made manifest by the parallels he uncovers with the two individuals.

\section{Parallels with (African) Cinema: The Filmmaker-as-Writer}

Lieux Saints focuses on Abbo, the writer, whose relationship to the filmmaker is somewhat subtle yet profound. The writer receives the least amount of attention in the film, but the rich and solemn-sounding musical theme that accompanies the scenes featuring him reinforces the character's importance. In fact, he is the only character who is paired with a musical leitmotif in the soundtrack; to recall Nichols, this expressive technique is illustrative of performative documentary. ${ }^{128}$ Abbo is dedicated to verbal art, and emphasizes that "la lettre" is fundamental to his personal and professional identity, for instance stating, "A, comme Abbo," with his finger pointed in the air. ${ }^{129}$ A self-proclaimed écrivain public, he explains to the camera

127 Barlet, Les cinémas d'Afrique des années 2000, 167.

${ }^{128}$ Nichols, Introduction to Documentary, 210.

129 "A as in Abbo." 
that he left behind his job as a senior technician to fulfill his dream of becoming a writer. ${ }^{130}$ Each day, Abbo composes philosophical phrases in chalk on a wall that is visible to anyone. His compositions are a source of pride for the people of Saint Léon, even if their meaning can be difficult to discern, as the narrator points out in voice-over: "[il] décorait les murs du quartier avec les réflexions pas toujours faciles à comprendre, mais qui faisaient la fierté des habitants du quartier."131 It is unclear whether Abbo's writing activities bring him any earnings. However, the impact of his writings on the lives of locals is evident in one scene where another character notices that Abbo had skipped the previous day's entry and asks him to fill it in, which Abbo does promptly.

Writing is one of the basic components of filmmaking, and the fact that Jean-Marie Teno authored the text of the film's voice-over narration establishes a connection between his craft and Abbo's. Both roles inevitably involve the use of words. Furthermore, the narration frequently incorporates Abbo's ideas and sayings, a technique that illustrates that the narrator/filmmaker and writer are in an ongoing dialogue. Where the two roles bifurcate is in the exhibition of their respective writings, and their ability to attain a readership or spectatorship. Abbo's method of writing exemplifies the notion of transmitting messages to the people. Indeed, several shots throughout the film frame his writings, highlighting their accessibility to members of the local community (figure 19).

\footnotetext{
${ }^{130}$ The term écrivain public holds a socio-historical function as it refers to a person who drafted letters and other documents for those who could not read or write or had little mastery of those skills. Ousmane Sembène's film Le Mandat/Mandaabi (1968) contains an écrivain public who allows Sembène to critique the postcolonial system that oppresses the main character and the other members of his community. In this example, the role of the écrivain public is negative whereas Lieux Saints highlights Abbo's positive part in the community.

131 "He decorated the walls of the neighborhood with reflections that are not always easy to understand but that filled the people of the neighborhood with pride."
} 

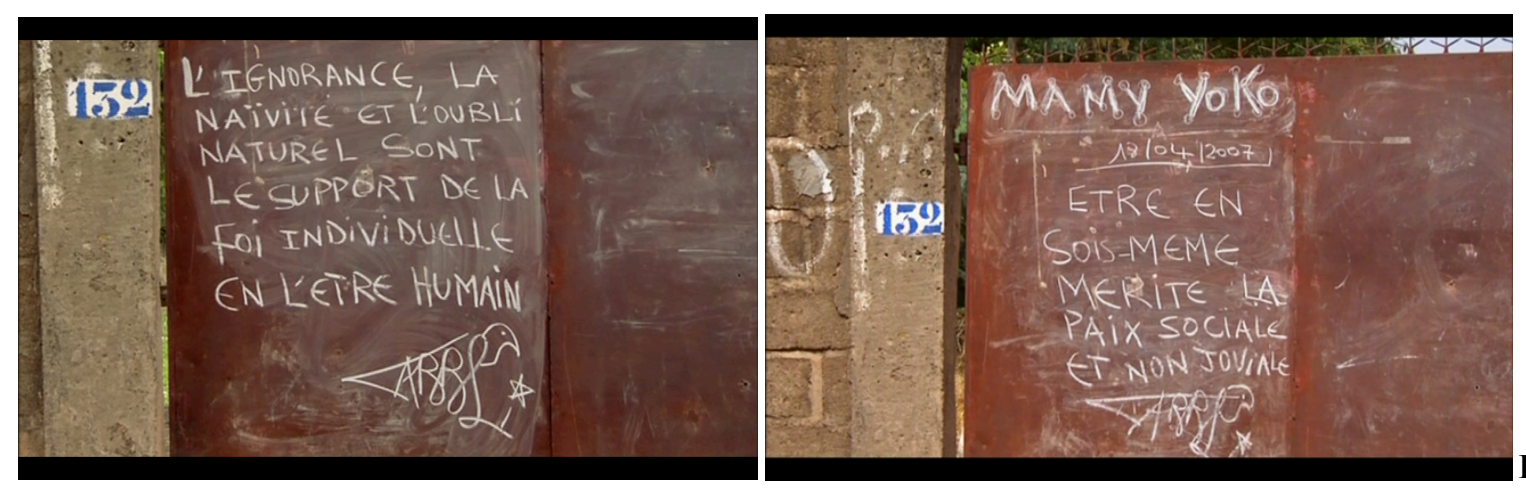

Fig. 19

Additionally, as the moments that feature Abbo in the act of writing make clear, words flow through him and immediately become written form, something tangible (figure 20). While these shots emphasize the art form's combination of both social and aesthetic functions, they also convey an implicit desire on the part of the filmmaker/narrator to make African films similarly accessible, to project them in free, open spaces, as it were. Following an encounter with Abbo, the narrator alludes to this desire in voice-over by comparing the neighborhood walls to screens: "Prendre la parole comme Abbo, pour réécrire son histoire sur les murs de la ville, ou sur les écrans plats de nos cases et de nos villas." ${ }^{132}$ In direct application of this idea, Lieux Saints contains a brief sequence in which the filmmaker presents his film Chef! at Bouba's ciné-club. Images feature audience members engrossed in the movie as it plays on the box television set, while the sound of the voice-over narrator in that film, also voiced by Jean-Marie Teno, fills the space. Even though this example is very brief in the film, it exemplifies the performative in the speech-act sense, by performing the action that it names. The filmmaker addresses and carries out the idea mentioned in voice-over: "prendre la parole $[\ldots]$ pour réécrire son histoire $[\ldots]$ sur les écrans plats de nos cases et de nos villas.”

\footnotetext{
132 "Dedicating oneself to the word like Abbo, in order to rewrite his story on the walls of the city, or on the flat screens in our homes."
} 


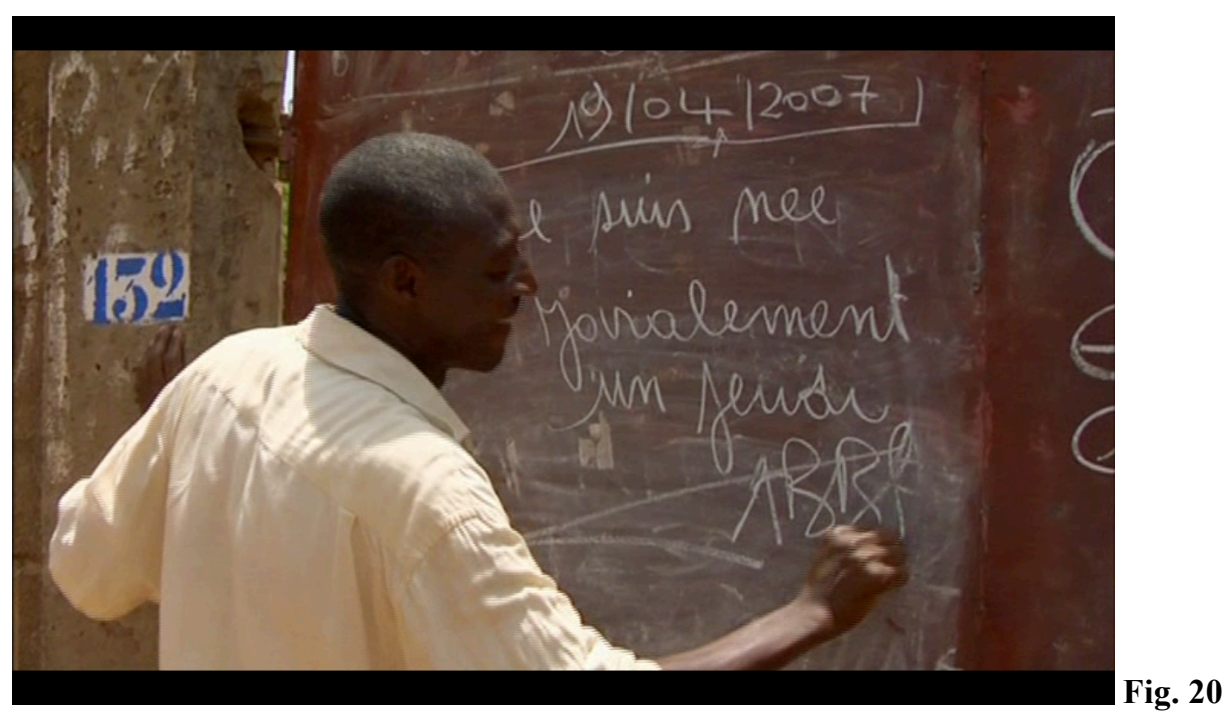

In addition to establishing parallels and discrepancies with filmmaking, Abbo's presence in the film also prompts reflection on past tendencies of African cinema. During the film's first encounter with the writer, he explains his career path-leaving behind a post as a technician to become a writer-and states that his reverence for the word drew him to his new vocation: "Au commencement était la parole."133 Deference for the word can be understood in terms of Francophone West African creation myths; according to many religions in the region, a "divine" spoken word activated the forces of life, including the human being. ${ }^{134}$ If we consider the influence of West African oral narrative forms on the work of filmmaking pioneers, like Idrissa Ouedraogo and Souleymane Cissé, Abbo's phrase dually refers to the origins of African cinema. Indeed, following a scene with the writer, the narrator states in voice-over: "Renoncer à la technique pour revenir à la source." 135 While this phrase describes Abbo’s career orientation, "la source" clearly indicates the beginning of creation, thus the word. Further, it signifies a narrative and aesthetic tendency in some African films and literature from the 1980s, which Manthia

\footnotetext{
133 "In the beginning was the word."

134 Thackway, Africa Shoots Back, 55. Abbo's line may resonate with creation stories in other cultures and religions. For instance, it is the first sentence in the Book of John in the New Testament.

135 "To give up on working as a technician/technique as a way to return to the source."
} 
Diawara qualifies as "return to the source." ${ }^{136}$ Perhaps, as it was for the filmmakers who once turned to this genre, precolonial African traditions may be part of the solution for the issues of contemporary African cinema.

Indeed, Lieux Saints contains a subtle reference to contemporary debates about African filmmaking practices, especially pertaining to the content of films themselves. When introducing Abbo in voice-over, the narrator makes an observation regarding his writing that highlights the positive response his work engenders in a local context, in spite of its somewhat challenging content: "les réflexions pas toujours faciles à comprendre, mais qui faisaient la fierté des habitants du quartier." This particular quality_"pas facile à comprendre"-is similar to contemporary African films that may be considered as elitist or intellectual and, thus, not geared toward local audiences in Africa. A dichotomy between commercial video movies and noncommercial filmmaking persists in contemporary practices, according to some recent African film scholarship; Abbo's art would represent the latter category. ${ }^{137}$ Several factors distinguish filmmakers of this category, which Lindiwe Dovey refers to as "festival" filmmakers, including class, education, and mobility (frequent travel and/or residence outside of the continent). ${ }^{138}$ She writes, "the mobility of 'festival' filmmakers from Africa [...] raises questions about their potential to relate emotionally and intellectually to local audiences in Africa." ${ }^{139}$ Abbo's work cultivates pride in Saint Léon, as the narrator mentions, indicating the potential for films that are also somewhat "difficile à comprendre" to achieve followers in a local context, if they are visible.

\footnotetext{
${ }^{136}$ Manthia Diawara, African Cinema: Politics and Culture (Bloomington: Indiana University Press, 1992). See pages 159-64. I discussed this tendency in Chapter 2.

${ }^{137}$ For instance, Matthias de Groof refers to the "discord between popular video film and auteur cinema, with Mahamat-Saleh Haroun at the forefront." de Groof, "How Text Reflects Context: Representation of African Film Audiences in Aristotle's Plot," Journal of African Cinemas 5, no. 2 (2013), 196.

138 Dovey, Curating Africa in the Age of Film Festivals, 6.

139 Ibid., 7.
} 


\section{'Tous les deux vont ensemble': The Djembe and Cinema}

In addition to Abbo, the film focuses on Jules César, the djembe player, who prompts explicit reflection on African cinema. Indeed, Jules César "sees the traditional drum as aesthetically inseparable, yet not indistinguishable, from cinema," as Justin Izzo remarks. ${ }^{140}$ In his first appearance in the film, Jules César carries out a technique that illustrates their interrelationship. A long shot shows him playing the djembe in the street at dusk. He approaches a group of men and ceases drumming to announce the movie playing at the ciné-club that evening, a screening of Jean-Marie Teno's film Chef! from 1999. He encourages them to attend, and then resumes his musical advertisement further down the street. Shortly thereafter, Jules César is seated before the camera and articulates his belief that the cinema and the djembe complement one another, "tous les deux vont ensemble," by qualifying their relationship as fraternal:

Le djembe c'est le koro et le cinéma c'est le dogo. Le koro c'est le grand frère; le grand frère c'est celui qui fait de l'histoire. Le djembe pour moi c'est le grand frère, il fait de l'histoire. Le cinéma est le dogo, ce qui veut dire petit frère. ${ }^{141}$

The filmmaker, who is off-screen, playfully objects by saying that as a cinéaste, he sees the two roles reversed, with the cinema as the ancestor to the drum.

While Jules César articulates the interrelationship between the cinema and the djembe, the film's formal and thematic attention to the drummer echoes, and enhances, their connection. For instance, it contains a lengthy scene with minimal dialogue in which Jules César completes the arduous task of constructing a djembe. This phase, "l'étape la plus sportive," gives the

\footnotetext{
${ }^{140}$ Izzo, “Jean-Marie Teno's Documentary Modernity," 46.

141 "The djembe is the koro and the cinema is the dogo. The koro is the older brother, he tells the story. For me, the djembe is like a koro, it tells stories. Cinema is the dogo, which means the little brother."
} 
instrument its sound. ${ }^{142}$ The images alternate from medium shots of Jules César seated on the body of the djembe to close shots framing his hands as he tightens and fastens the cords that hold the head of the drum in place. There is no music in this sequence, except for the squealing sound of the stretching cords that produces its own tune. As Jules César draws closer to completion, the shot inches closer to him. It cuts to a close-up image of his face covered in perspiration that practically overspills the frame (figures 21-23). He wipes his forehead and, smiling, recites a saying, "Il faut suer pour manger." "143 When he is satisfied with the instrument's sound, he sits back and launches into an upbeat rhythm.

Figs. 21-23
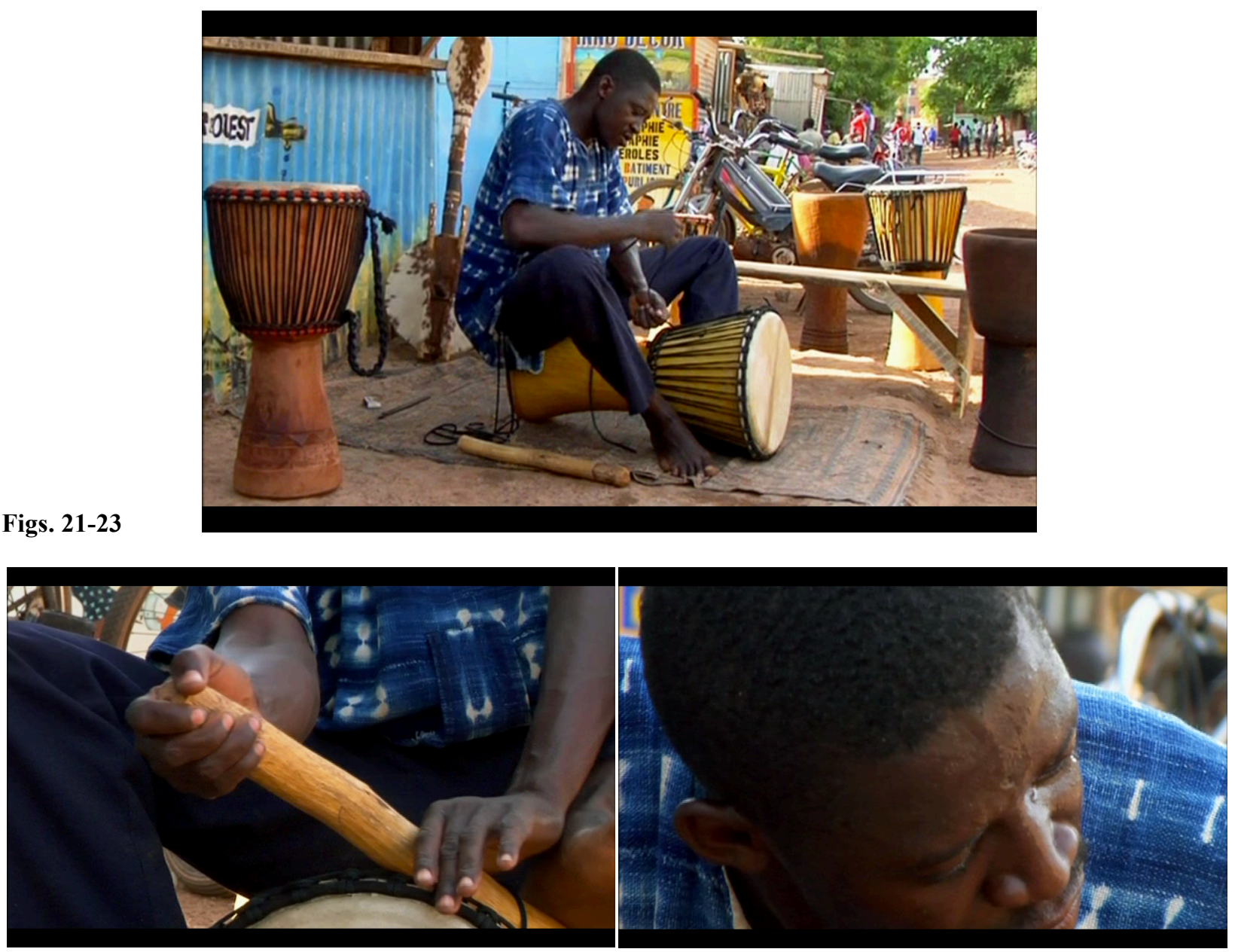

\footnotetext{
142 "The most strenuous stage."

143 "One must sweat in order to eat."
} 
Filming the phase of djembe construction at length and in increasingly close range reflects the parallels Jules César's activities have with African cinema. The camera witnesses the creation of a local product that is designed for local consumption, which relates to Lieux Saints' overarching question with respect to African cinema. But beyond its thematic resonances with the issues that pertain to filmmaking, the scene establishes a symbiotic relationship between the two respective art forms. The phase that Jules César executes for the camera brings the instrument into being. Sound is foundational to the djembe, as it allows for the instrument to carry out one of its primary functions, which Jules César tells the camera is to "regrouper les gens." ${ }^{, 144}$ By foregrounding this moment, the film accentuates the instrument gaining its voice, or mode of transmission.

With respect to African filmmaking, the idea of transmission also refers to the next generation. A lack of resources prevents collaboration between filmmakers of different generations; as a result, to recall Teno's aforementioned quote, "each new generation acts like it thinks it has reinvented the wheel!" ${ }^{145}$ Conversely, Lieux Saints highlights inter-generational collaboration in the art of djembe-making and playing. For instance, Jules César mentions his teacher and his intention to become a grand djembe fola, which not only entails instructing how to play the instrument, but also spreading the instrument's philosophy: "celui qui transmet la philosophie, le message du djembe." Further, the film provides a striking visual example of the possibility of transferring the art of the djembe from one generation to the next by focusing on a child who plays a makeshift drum, reminiscent of a djembe. A first shot frames a group of young boys, who face and smile at the camera. One of the little boys, the youngest of the group, clutches a tin can, which he plays like a drum. The boys scatter, and the camera follows the little

\footnotetext{
144 To "gather people together."

145 Teno, "Writing on Walls."
} 
boy with the can as he walks while tapping it continuously (figure 24). Here, he gazes out of the frame, a visual metaphor for looking towards the future. The shots immediately precede the lengthy sequence of Jules César constructing a djembe, alluding to the possibility that this young individual, as well as others, may one day take on a similar artistic role.

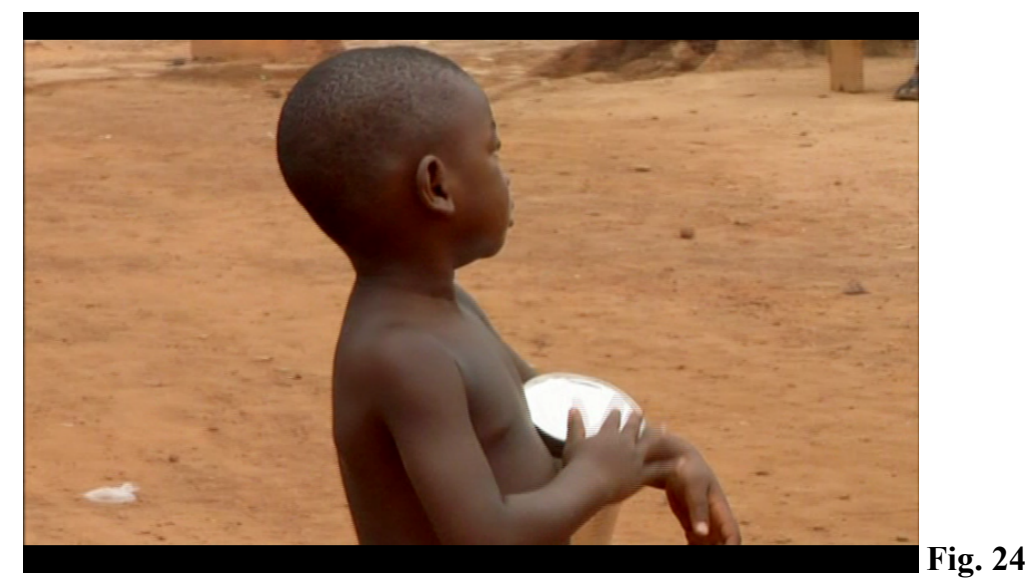

In addition to tracking thematic parallels between Jules César's artistic endeavors and cinema, the film gradually incorporates Jules César and his instrument into its structure. First, the voice of the djembe becomes embedded throughout as it features the drum's sounds even when Jules César is not in the frame. Izzo cleverly refers to the "relentlessly joyful beats" Jules César produces as "acoustic dissolves" that weave in and out of sequences dealing with his music and the ciné-club. ${ }^{146}$ Indeed, like in film editing in which a dissolve creates a gradual transition from one image to another, the drumbeats provide transitions in the soundtrack. Thus, the djembe contributes to, and creates, the film's rhythm by providing pauses and by picking up the tempo.

Like his instrument, Jules César's voice also becomes part of the voice of the film. In a sequence near the beginning of Lieux Saints, he introduces himself and describes his work, while images focus on him as he rides into Saint Léon on a moped and begins a typical day. Unlike the sequences featuring other characters, his dialogue plays in voice-over rather than synchronously.

${ }^{146}$ Izzo, "Jean-Marie Teno’s Documentary Modernity," 47. 
This technique splits the voice of the film to include both the narrator's and Jules César's, which brings them onto the same plane. By taking a step back and bringing Jules César's dialogue into voice-over, Teno equates the importance of the character and his art form to his own; to recall Jules César's idea from the beginning of the film, "les deux vont ensemble." Just as significant as the technique of splitting the voice is what Jules César says in voice-over. He describes the djembe in a way that foregrounds its relationship to oral tradition and the griot. "Pour moi, le djembe est un instrument de sagesse... un instrument sacré. Comme on dit, l'histoire a toujours

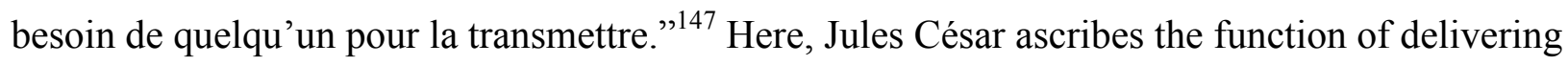
a story or message to the djembe, qualities that relate to the griot's roles as s/he who preserves and transmits stories, history, and knowledge. That this occurs in voice-over, a filmic technique, signals a new mode of transmission.

At the end of the film, Jules César and the djembe share the voice of the film and the screen with the filmmaker. While reflecting upon his time in Saint Léon in voice-over, the narrator conveys his surprise at discovering so many similarities between "le djembe et son frère le cinéma." Here he adopts Jules César's formula from earlier in the film, and even leaves cinema in the subordinate role as the "little brother." Jules César's voice seamlessly takes over and, as is customary, he begins reciting proverbs and stories. His voice fades out as the narrator's resumes, telling two stories that he learned from Jules César. They pass the voice back and forth, and the narrator adopts Jules César's storytelling form. The second story describes a man running after an object to discover once he reaches it that it reflects the images of his ancestors, his own image, and a djembe, a metaphor for what Teno uncovers in this quest in Saint Léon. As he finishes the story, the image centers on a street scene with two djembes sitting prominently in

\footnotetext{
${ }^{147}$ I believe that the djembe is a tool of wisdom, a sacred instrument. As they say, history/a story needs someone to transmit it."
} 


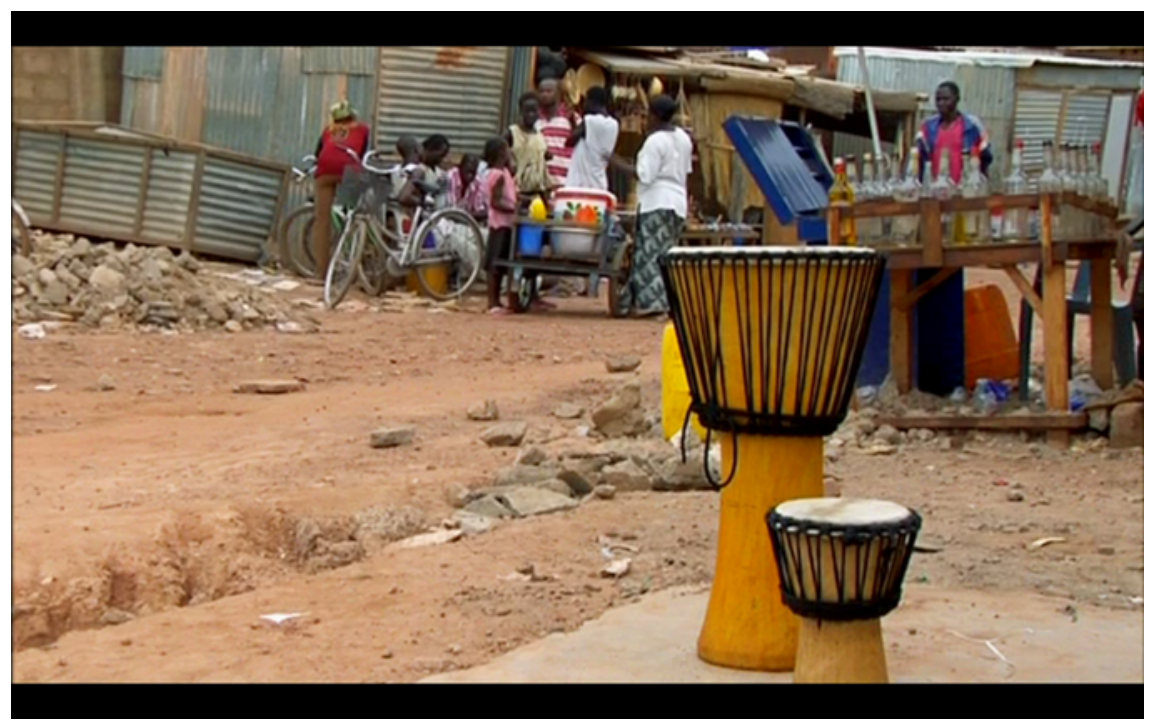

Fig. 25

the foreground (figure 25). One is large and the other one is small, to illustrate the big brother and little brother relationship between the drum and the cinema. Beyond signaling a relationship of kinship, of proximity, the next shot-one of the last shots of the film-merges the film/cinema and the traditional drum. In close up, the image frames Jules César's hands drumming a fastpaced rhythm. Whereas the rest of the shots featuring the djembe are situated opposite Jules César and the drum, the camera is positioned on the same side of the djembe as Jules César

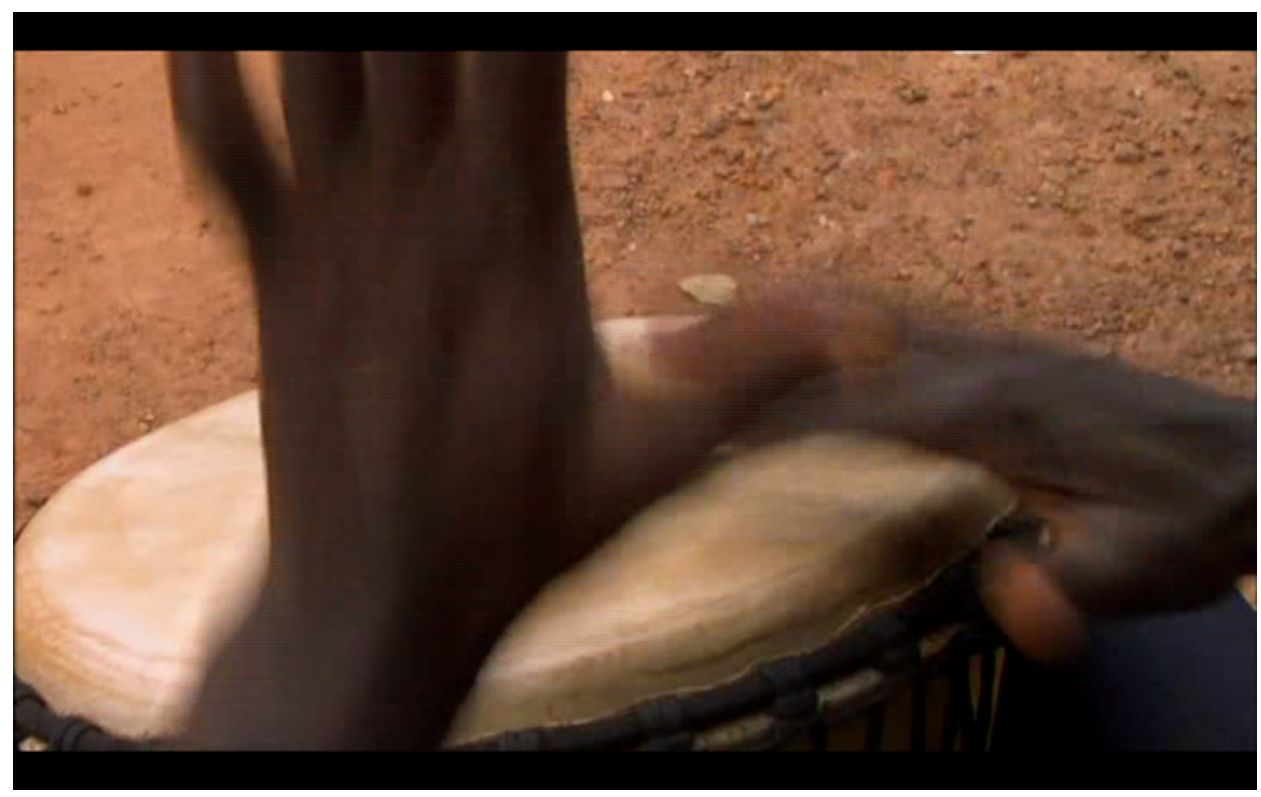


(figure 26). This point-of-view shot brings Teno's project fully into focus, that by aligning the djembe and the cinema through thematic and formal devices, Lieux Saints signals new creative possibilities for African cinema.

In his closing lines of the film in voice-over, the narrator states that his trip to Saint Léon constitutes "un pas vers la redécouverte de notre ancêtre le griot."148 While his "rediscovery" of the griot is a means to define a future for the broader state of African cinema, he reflects upon documentary film in particular, a reflection that is prompted by Jules César's definition of the griot. Addressing the camera, Jules César describes the griot's role:

Le griot, il dit des choses aux gens [...] Il les fait découvrir quelque chose qu'ils n'ont jamais vu ou [dont] ils ont entendu parler mais personne n'a jamais eu l'occasion de leur parler de ça. Pour moi, le cinéma est comme un griot qui passe de pays en pays pour pouvoir montrer ce message. ${ }^{149}$

In voice-over, the narrator applies this definition to documentary film, which dovetails with the notion of transmission. He equates documentary with the function of the griot, thereby emphasizing this filmic mode in particular as a solution for connecting with local audiences.

In Teno’s essay published shortly after the release of Lieux Saints, he discusses Moussa Touré's Poussière de ville (2001), a film that could be considered performative according to one of Stella Bruzzi's broad categories of performative documentary. ${ }^{150}$ Indeed, the film is "inherently performative," as it features "the intrusive presence of the filmmaker." 151 As Teno explains in his article, Poussière de ville raises "important ethical questions" for the fact that

\footnotetext{
148 His trip to Saint Léon constitutes "a step towards the rediscovery of our ancestor the griot."

149 "The griot communicates things to people. He brings them to discover things that they have never seen or things that they have heard about but no one has ever explained it to them. For me, the cinema is like a griot that goes around from country to country to promote a message."

${ }^{150}$ Teno, "Writing on Walls."

151 Bruzzi, New Documentary, 155.
} 
Touré intervened in the lives of his film's subjects: "while shooting [...] Moussa went looking for the families of his characters, the street kids, [thus] he was going beyond the habitual role of the filmmaker vis-à-vis his subject by assigning himself the duty, the responsibility of taking the kids back to their relatives." "152 Teno himself performed a similar gesture while shooting a scene of Chef! When a little boy is about to be beaten for petty theft, the image suddenly goes black and the narrator-voiced by Teno, as in Lieux Saints-says in voice-over that he had to intervene. He steps in to save the boy from being harmed and possibly even killed. The idea of intervention relates to Bruzzi's theory that documentary film is inherently performative; it is inevitably the result of an encounter between filmmaker and subject, as the filmmaker's intervention into a situation alters that situation irrevocably. I propose that Bye Bye Africa and Lieux Saints are also performative in this sense. Their respective films' subjects are African cinema, a subject into which both Haroun and Teno intervene in their efforts to challenge and reassess the contemporary situation. By shooting, or stepping in, at a critical juncture, they attempt to alter the cinematic landscape, an undertaking that also charts new roles for the contemporary African filmmaker.

As this chapter has strived to demonstrate, in Bye Bye Africa and Lieux Saints, Haroun and Teno both examine and enact the subjects they explore. In this respect, their films are reminiscent of performative documentary as defined by Stella Bruzzi as films that "simultaneously both describe and perform an action." ${ }^{, 153}$ Mahamat-Saleh Haroun's character in Bye Bye Africa performs making a film to reflect on the process of cinematic creation as well as its inherent challenges specifically in the context of Chad's film industry. The performative strategy in Bye Bye Africa corresponds to Haroun's larger aims of seeking to build a tradition of

\footnotetext{
152 Teno, "Writing on Walls."

153 Bruzzi, New Documentary, 8.
} 
filmmaking in the country. Lieux Saints focuses on artisans and individuals involved in their work, namely a writer and a musician, to track parallels and discrepancies between these other art forms and filmmaking. While Teno's film foregrounds the problems facing African film, it also enacts a solution by depicting the interrelationship between cinema and other art forms, thereby signaling possibilities for regeneration. In their films, Teno and Haroun evaluate and reassess the contemporary issues concerning African filmmaking and spectatorship. Their attempts to think through the future of African cinema indicate that this engagement is at the heart of the African filmmaker's role going forward. 


\section{Conclusion}

In Jean-Marie Teno's essay published shortly after the release of Lieux Saints, evocatively titled "Writing on Walls: Documentary, The Future of African Cinema?," he raises the stakes involved in a filmmaker's efforts to connect with certain types of audiences. Teno gives the example of Moussa Touré's documentaries, Poussière de ville (2001) and Nous sommes nombreuses (2003), films that were screened in Touré's native Senegal, but that are difficult to find internationally. Teno asks,

can the filmmaker, as an artist, allow him/herself to be defined by others who have the means to manipulate and orientate the reading of his/her work, or should he/she be writing on the walls like Moussa [Touré] in his neighbourhood, at the risk of not being seen further afield? Are those who choose to write meaningful things on the walls, for their communities, more likely to survive in the long run, to make more lasting impact, than those who run after the mirage of a global recognition? ${ }^{1}$

Teno's question touches on the persisting division in contemporary African filmmaking practices of art cinema and popular films, and their audiences. A key question facing filmmakers remains whether African films should seek higher aesthetic and political goals, at the risk of forgoing African audiences, or whether they should focus on catering to a mass market on the continent. Interestingly, two years after the publication of Teno's essay, Moussa Touré's feature film $L a$ Pirogue (2012) received considerable international recognition, competing in the "Un Certain Regard" section at Cannes.

\footnotetext{
1 Jean-Marie Teno, "Writing on Walls: Documentary, The Future of African Cinema?," Africultures, March 21, 2011, http:// www.africultures.com/php/?nav=article\&no=10003.
} 
The question of spectatorship of films made in the art cinema tradition is not specific to African filmmaking. Certain viewers will prefer the films in the art house circuit to the latest Hollywood blockbusters. Similarly, "there will always be audiences who will prefer Abderrahmane Sissako's Bamako to all two thousand of the Nigerian videos produced in the same year," and vice versa, as Jonathan Haynes points out. ${ }^{2}$ However, with little to no exhibition possibilities in many countries across the region of francophone sub-Saharan Africa, African directors are consistently confronted with the question of their intended audience, a question that Jean-Marie Teno feels one would not ask an American filmmaker, for example. ${ }^{3}$ For Philip Rosen, art cinema by African directors is a "utopian cinema. It constructs a utopian spectatorship," by seeking international audiences while simultaneously aiming at an African audience. ${ }^{4}$ Instead of making films with specific audiences in mind, Jean-Pierre Bekolo conceptualizes his approach as "making movies from a place, rather than making movies for an audience...why don't you just make movies from where you are: 'this is what I see from here.",5 Bekolo's idea raises the idea of a filmmaker's location in relation to their work, the implications of which merit further attention.

The contemporary filmmakers examined in this project, Bekolo, Teno, BakupaKanyinda, and Haroun, reside or spend the majority of time outside of their countries of origin, often shuttling from one African nation to another, or (most often) from Africa to Europe or North America. Thus, their nationalities rarely reflect their places of residence. They circulate around the globe, participating in festivals and panels, and giving talks. Artist-intellectuals, and

\footnotetext{
2 Jonathan Haynes, “African Cinema and Nollywood: Contraditions," Situations: Project of the Radical Imagination 4, no. 1 (2011), 81.

3 Interview with Melissa Thackway. Bonus feature on Lieux Saints DVD.

4 Philip Rosen, "Notes on Art Cinema and the Emergence of Sub-Saharan Film," In Global Art Cinema: New Theories and Histories, Rosalind Galt and Karl Schoonover, eds. (Oxford: Oxford University Press, 2010 ), 260.

5 Jean-Pierre Bekolo, Interview by Anna V. Keefe, 14, February 2014, UVA, Charlottesville, VA.
} 
global citizens, they publish essays and books and, in some cases, they teach; Bekolo and Teno have both taught at universities in the United States. In his book, Postcolonial Artists and Global Aesthetics, Akin Adesokan highlights the metropolitan location of contemporary African artistintellectuals as providing them with economic security, such as funding opportunities and technical support. ${ }^{6}$ Opportunities for co-productions, exhibition spaces, and intellectual debate certainly abound in these contexts as well, as Eileen Julien points out. ${ }^{7}$

What remains to be seen is the degree to which a filmmaker's location inflects their work. Specifically, does location prompt a self-conscious reflection on filmmaking, and on cinematic form, that is enhanced by residence abroad, or by nomadism? Attempting to draw connections between self-conscious tendencies and an artist's place would require theorizing a relationship between cultural production and location. Eileen Julien raises similar questions in her essay, “The Critical Present: Where is 'African Literature'?” Prompted by the striking thematic and formal shifts in contemporary African cultural production (including, but not limited to, film), she asks,

is there a vast difference between the texture of texts produced by those living and working in Africa and that of texts produced by those living and working abroad? Does old-style realism remain the dominant literary mode on the continent? Are explicit depictions of sexual acts or queer sexualities, postmodernist and avant-gardist experiments, which are rife elsewhere, eschewed in Africa? ${ }^{8}$

Julien does not delve deeply into these questions, but she briefly traces cultural and artistic production by artists of previous generations in order to show that "African" texts were never

\footnotetext{
${ }^{6}$ Akin Adesokan, Postcolonial Artists and Global Aesthetics (Bloomington: Indiana University Press, 2011).

7 Eileen Julien, “The Critical Present: Where Is 'African Literature'?," in Rethinking African Cultural Production, ed. Frieda Ekotto and Kenneth Harrow (Bloomington: Indiana University Press, 2015): 23.

${ }^{8}$ Ibid., 17.
} 
only African, early artistic production was more complex than scholars perceived, and scholars may have overlooked formal innovation in contemporary creative practices on the ground in Africa. Thus, she ultimately argues that, even though "'location' can be critical in any number of ways...new emphases and experimentation in the creative works of African artist-intellectuals are more a matter of 'time,' which is to say history, than 'place.",9

The global citizenship of these filmmakers prompts reflection on 'African' cinema, a concept that has always been and continues to be in flux. In the spirit of Julien's question, what and where is African cinema? As the first chapter of this study indicates, African cinema is world cinema. By this, I do not wish to suggest that 'world cinema' is a particular category of film, such as the distinction between 'French' and 'Francophone' often implies. Rather, I mean to emphasize its global scope, as Lina Khatib does in Storytelling in World Cinemas. ${ }^{10}$ To theorize the global scope of African cinema, putting African films in dialogue with works from Europe, the Americas, and Asia, remains a productive area of inquiry. We might also consider African films as independent filmmaking that is produced by funding sources that are increasingly global in nature.

Notions of world cinema and global cinema aside, African cinema is in the world. While this point may seem obvious, recent examples such as the unprecedented success of Abderrahmane Sissako's Timbuktu (2015) indicate an increasing visibility of films by African directors on screens worldwide. In fact, if we recall the manifesto by La Guilde Africaine des Réalisateurs et Producteurs, Timbuktu achieves the visibility to which they originally aspired: "Rêvons de la sortie d’un film africain dans 30 salles à Paris, 80 salles Paris et périphérie, 700 salles en France, 3000 salles en Europe, 1000 salles en Afrique, 10.000 salles dans le monde

\footnotetext{
9 Julien, "The Critical Present," 23.

${ }^{10}$ Lina Khatib, ed., Storytelling in World Cinemas, Vol. 1: Forms (London: Wallflower Press, 2012 ), 1.
} 
entier..."11 Timbuktu was awarded seven Césars, including the award for best film, and it brought in over 750,000 spectators in France. ${ }^{12}$ As this compelling example suggests, and as a potential extension of this study, the directions francophone African cinema is taking are increasingly global in scope.

${ }^{11}$ La Guilde, Pour un nouveau cinéma africain; See Appendix 1.

12 Olivier Barlet, "Timbuktu, Le chagrin des oiseaux, d'Abderrahmane Sissako. Les visages de la dignité," Africultures, http://www.africultures.com/php/index.php?nav=article\&no=\%2012233. 


\title{
Appendix 1
}

\section{Pour un nouveau cinéma africain}

\author{
Par La Guilde
}

\section{Identités.}

S'il est important de savoir d'où l'on vient, il est surtout essential de savoir où l'on se trouve, c'est-à-dire définir notre place de cinéaste africain dans le monde. Ce positionnement qui est en fait une prise de conscience, nous aidera à clarifier notre regard sur l'Afrique. Même si les identités sont aujourd'hui transversales, notre dénominateur reste ce continent et la représentation qu'on en donne en images. L'histoire nous a appris que les premières images de nous, ont été réalisées par un cinéma qui nous regardait de haut; des images destinées à un public bien précis. C'était le début du cinéma colonial. Il y en a encore parmi nous qui filment l'Afrique de ce point de vue-là.

Ici, plus qu'ailleurs, il nous faut réviser l'histoire : rappelons haut et fort que Griffith n'est pas une référence pour nous, nous ne pouvons oublier la représentation qu'il avait donnée des Noirs... Depuis, d'autres ont suivi, malheureusement, et parfois même parmi nous. Ceux-là filment la représentation que les autres ont de l'Afrique... Ce cinéma de la schizophrénie, nous n'en voulons pas.

\section{Altérités.}

Prendre conscience de sa place dans le monde ne veut pas dire s'en éloigner. Bien au contraire. Nous sommes pour la plupart des cinéastes en mouvement, au contact des autres. Nous sommes les cinéastes de l'errance, du nomadisme. Comme tout bon nomade, il faut avoir une bonne monture pour avancer; et notre monture à nous c'est le cinéma. Notre cinéma ne peut être que celui du voyage, donc ouvert aux horizons... Comme l'écrit l'écrivain Nigérian Ben Okri dans Étonner les Dieux, « je voyage pour savoir pourquoi je suis invisible ». Un voyage sans complexes vers les autres. Loin du cinéma ethnographique qui enregistre les us et coutumes, le nouveau cinéma devrait tout simplement nous rapprocher de la grande famille du cinéma. Nous n'oublions pas que nous sommes des cinéastes africains, mais nous sommes d'abord cinéastes.

\section{Modernité.}

Par modernité, nous entendons les signes avant-coureurs annonciateurs de nouveaux courants ou explorateurs du langage cinématographique. Ce n'est pas un hasard si les quatre films suivants traitent, à leurs manières du même thème : Bye bye Africa, Immatriculation temporaire, La vie sur terre, Vacances au pays... En tant que cinéastes, nous ne pouvons pas fermer l'œil devant les problèmes actuels et urgents de l'Afrique. C'est de cette Afrique réelle qu'il faut rendre compte à travers des images authentiques. Mais veut-on vraiment s'interroger sur les problèmes douloureux qui se posent... C'est peut-être la raison pour laquelle le documentaire de création est en déficit chez nous... 


\section{Solidarités.}

Face à la mondialisation, au cinéma dominant hollywoodien, il reste très peu de place pour les images africaines. Et quand les télévisions comme TV5, CFI ou Canal Horizon se mettent dans le rang, c'est pour mieux nous tuer, achetant nos films à des prix défiant toute braderie. C'est en nous rassemblant et en proposant un barème tarifaire minimum à toutes ces chaînes spécialisées sur l'Afrique que notre travail sera respecté. Le respect de notre travail avant tout.

Cela dit, toute solidarité sous-entend une grande part de générosité et un amour foncier du cinéma. Les jalousies, les petites bassesses ne peuvent être que l'œuvre de quelques imposteurs. Qui aime le cinéma ne peut que se réjouir de la défense de ses intérêts...

\section{Visibilités.}

Rêvons de la sortie d'un film africain dans 30 salles à Paris, 80 salles Paris et périphérie, 700 salles en France, 3000 salles en Europe, 1000 salles en Afrique, 10.000 salles dans le monde entier...

Un film africain que le reste du monde découvrirait et prendrait plaisir à aller voir, non parce qu'il est formaté pour répondre aux attentes du marché, mais parce qu'il éclaire enfin le reste du monde sur la vie, l'esthétique et l'état de la création dans cette Afrique fantasmée, caricaturée et si souvent mal représentée.

Rêvons toujours : un film qui ne sera pas une superproduction aux budgets faramineux, mais un film indépendant, peut être tourné avec une petite caméra numérique, loin des dogmes et autres caprices des gosses de riches, qui s'attaquerait avec audace à cette barrière que l'histoire a tissée autour du cinéma africain rendant très difficile son rapport au spectateur " global ».

Ce film sera le travail d'un auteur ou d'un groupe d'auteurs, jeunes et libres dans l'esprit, qui auraient pris la peine de faire le tri entre le superflu et le nécessaire et qui trouveraient enfin la force de s'attaquer aux sujets qui préoccupent leurs compatriotes aujourd'hui et qui se trouvent être les mêmes sujets qui préoccupent les gens dans le monde entier.

Pour que ce rêve se réalise, il faut refuser de rester hors du monde, refuser la culture de la marge, refuser de se réfugier dans un passé magnifié, il faut nous regarder sans complaisance, c'est-à-dire s'accepter avec toute notre mémoire : notre cinéma ne pourra qu'enrichir le cinéma mondial en révélant au reste du monde sa face la plus...noire et la moins connue.

Allez, encore un petit effort. Ça bouge. Ça va venir. Fatalement.

Published in Afriques 50 : singularités d'un cinéma pluriel, Catherine Ruelle, ed. (Paris: L'Harmattan, 2005): 269-71. The year in which the document was drafted is not specified, nor are the specific authors' names. 


\section{Appendix 2}

\section{Interview with Jean-Pierre Bekolo}

The University of Virginia, Charlottesville, VA

February 14, 2014

Anna Keefe: I would like to ask you to talk more about the idea of "expanding the visible," and how this is tied to your project as a filmmaker.

Jean-Pierre Bekolo: One of the first things as a filmmaker is you have to make sure that whatever you're embracing as a topic is a cinematic topic, meaning something that actually suits the medium of cinema. There are many things where cinema is really not the best medium to express it, so you must address if this is really something for cinema. That's the reason why I try to test my idea visually, so I always have to make sure that visually it is relevant. That's why the definition of cinema is a way to expand the vision or the visible, so that people will actually see something that they've never seen before.

I always like to use a very popular expression in Cameroon; people say, "There is cinema out here," Venez voir du cinéma ici dehors/Arrête ton cinéma... Why do they feel that this is cinema? Why is this that popular definition of cinema? I always think it's because it's something to see. If there's nothing to see, there's no cinema. ...I think that it's important that whatever it is you decide to tap into as a topic that there's cinema behind it, meaning it's something to see.

My father was a police chief. We were one of the first families to have a VCR. We moved to a small town, and he made sure that he had stuff to detain us. He had to have the very first VCR that came out, that was in the late 70s. We'd watch a lot of stuff. My younger brother was the one to watch the films with him before we could watch them, and we'd always ask him, was it a good film? Was there any killing in it? So killing was the measurement of what is a good film! It's a French film if they only kill once. So I wonder when we were kids, why were we measuring films according to the killing. It's obviously because it's something that is very far from reality. Points out the difference in the sound of gun shots in French film (pah pah!) and American film (choo choo!) It's funny how killing becomes the way you measure how real, or how cinematic it is.

AK: Is this intuitive to you?

JPB: Not really. We have our visual experience, our visible experience, and when there's something new, out of what we know, as cinema, then there's cinema behind it. If it's something beyond our experience of the visible.

AK: To what extent is cinematic material tied to the imaginary/l'imaginaire?

JPB: It's not just about the imagination or the imaginary. Obviously it's part of it, too. But what I like is also the idea that we have the ability to reinvent our experience or our world through cinema. So it's not something that should stay in the imaginary, it's something that could become. As you experience it, you don't just think it's possible, you even think it's true. So it's 
not just something that should stay in the imaginary world, it's also something that should be completely possible.

Actually, one time, a girl gave a paper in which she was comparing Jean Rouch's work to my work; I was kind of shocked. But when she read it, she was actually saying that we're dealing with, let's say, the African experience in which Africa is still to be reinvented. Both of us deal with the African experience, where whatever we describe we actually don't stick to the reality of Africa, we almost create our own Africa most of the time, which I kind of agree with. I don't really look at the contemporary Africa as something finished, cooked, because it's also a product of colonialism, and all this stuff. So, I don't want to freeze that reality; I kind of want to continue the process somehow, to reinvent it. So the imaginary also has that function, of reinventing a world that was actually imposed on us somehow through colonialism.

AK: That's why I find Les Saignantes so fascinating, because it demonstrates this desire to reinvent reality, although the reality we see in that film is post-apocalyptic, dystopian, where everything is frozen, and so what you do there is put on the screen and in people's faces what you wish to be changed, rather than after the change.

JPB: Absolutely. It's almost like destroying everything - that explains the darkness. So you have the possibility to deny what exists, more than proposing something.

Which actually is what I'm supposed to do with this film I shot in South Africa, to propose something. It's supposed to be science fiction, we shot all in green screen, so now we need to create a space, reinvent everything. Also the things we want to invent don't exist. But I'd say that Les Saignantes was actually the complete opposite of this, because it was negating what is out there.

AK: That's why I think the cinematic allegory is so pertinent, because in the film about reinventing reality, we see a performance of remaking something - with the SGCC's body.

A: Yes, I do think that it's very interesting how we enter cinema. Let's say when you try to take a photo of somebody in Africa, they always make sure that they dress up and all these things. I think it's very important to take into account how people want to be seen, the way Africans want to be seen. It's not just taking people's picture the way they are in reality, but let them stage themselves. It's important to respect that, instead of just taking people in their daily...they have to be metteurs-en-scène of their own image, their own film.

AK: Like the MTV-like scene in Chouchou's bedroom where the girls are trying on clothes and getting ready for the DGP.

JPB: Exactly.

AK: By the way, is DGP an actual term?

JPB: I made it up. I like creating things like this that might stick afterwards.

AK: And SGCC? 
JPB: Actually it's a mix of two things. In Cameroon, one of the most powerful people is the SGPR, which is the secretary general of the President, and then the other one is the Directeur du Cabinet Civil, DCC, who runs the President's office. It's a combination of both. The SGPR is running the presidency, and the other one is running the President's private life. (I think) I like that these names are produced by the system, and they become symbols. [These names] are very cinematic, too.

AK: To what extent is the depiction of the future, for instance the representation of technology, exaggerated in Les Saignantes? Matthew Omelsky refers to the cover of darkness as one of several "hyperbolic depictions of African pathology," or appropriating Western stereotypes of the continent and exaggerating them as a way of owning the stereotype. ${ }^{1}$

JPB: This film is supposed to be 20 years from the moment we made the film, and you wonder how were things different from 20 years back? Not much difference. So I think in general we speculate, and have all these questions about the next 20 years, but when I look back 20 years before in Cameroon what was really different? Not much, really. So why do I think the next 20 years will be very very different? And whatever difference that comes is a Western thing, we're not the ones making cell phones, or making all these computers, so we just receive whatever we receive. Insisting too much on technology as objects by themselves was more coming from the West sending us stuff. But what I like the most mainly is the interaction of people on the technology, how they use it. That, for me, was more important than the object itself - the behavior in front of the technology.

AK: Can you comment on the on-screen text in the film?

JPB: It's very clear that as a filmmaker I had to intervene, to really say how it was impossible to make science fiction in that context. I always like to say how do you have a car chase in a country where you never have gas? Each time you call the police, they ask you if you have gas money [so if they come they can be paid]! So I'm really trying to say that you have to adapt to the context - whatever genre you see, you have to apply to Africa, to take the context into account. That's why I felt that as a filmmaker if I'm getting into science fiction, horror, or detective genre, and I'm stuck because of the context, I cannot go further; how do you make an investigation film in a country where you're not allowed to investigate? How do you make a horror film where death becomes a party? I really try to contextualize cinema itself, as a genre, so it doesn't become a cliché of what a genre is supposed to be.

AK: Intervening as a filmmaker is a very interesting stylistic thing that you do. We see it most explicitly (and with the most attitude!) with Aristotle's Plot where you lay bare the circumstances you're dealing with. Could you comment on this stylistic device - intervention of the filmmaker - with regards to Le Président?

JPB: Obviously, as you can see, I don't like recipes, formulas. Each film should reinvent... should be a piece by itself. There will be similarities, because they're made by the same person, but I find repeating the same film to be kind of annoying. On the use of screens in Le Président

\footnotetext{
${ }^{1}$ Matthew Omelsky, “Jean-Pierre Bekolo's African Cyborgian Thought,” Nka: Journal of Contemporary African Art (Fall 2012), 6-21.
} 
...[this film] is also a critique of a mediatized society. Jo Wood'ou is talking so much, but doesn't know much - the whereabouts of the president. If I take the context of Cameroon specifically, where you are supposed to have liberalized media, where people are supposed to have freedom of expression, but at the same time they don't! It's a lot of noise for nothing. Very strange journalism, as well - very narcissistic. All of these things are the product of - I don't want to say dictatorship - but political African...being controlled by one man.

$\mathrm{AK}$ : What is it exactly in the background?

JPB: Digital effect - we used a lot of digital graphics ...generique...3D graphics, white noise graphics. To create this media world - African contemporary media world that is very digital, supposed to be technology, modern, somehow.

AK: Coming back to the notion of appropriating Western stereotypes, do you feel that this speaks to your projects as a filmmaker?

JPB: It's very complicated. I treat films as a closed world. Quartier Mozart is like that. Les Saignantes is like that. The President is like that. So I really try to create a world based on the world the film is inspired from. Basically if there are Western references, they are references that are being produced from within that closed world. Because what is western and what is not anymore in that context? I want to say that some Africans have started mimicking the west. So is it really necessary to compare it to the West? Where (or what) is the Western world in this postcolonial Africa? That is a kind of parody of the west (laughs) I mean not parody, but imitation of the West.

AK: The notion of each film being a closed world seems related to your idea of "tribal cinema."

JPB: Yes. The idea that the community involved is like a little tribe with their own codes, etc. It might not be accessible to everybody, but I just like the fact that it's a little world people experience. One of the principles that is useful is that you are sharing with people references they're not familiar with, that the film you're making is a story that they don't know, or a world that is worth talking about. Obviously you can make films about the world everybody knows, films that are open completely, but I like that closed world. Maybe because I always want to depict Cameroon may be why I want to close it.

AK: Do you ever see yourself setting a film outside of Cameroon, a Cameroonian context, or even African context?

JPB: I really have no rules about it. I think that whatever I do with Cameroon I can do anywhere else. So far it's Cameroon, because I just feel like I want to do that, but I don't really feel tied to it. It's not systematic. I like questions about Cameroon, about Africa; it's not because I'm African, I just like that topic. I always say about Les Saignantes that I deal with girls like I deal with cops - it's not really about gender. I like those characters because they could help me tell my story better. Girls are politics for me...sex, prostitution...so it was the best choice of characters, the best topic, for me to make a political film. And the film is not just about Cameroon; it's about human beings, really. And on a larger scale, [it's about] human corruption. 
Cameroon is a kind of model I have handy, and which I like, but I think extrapolating it to another context would be no problem; dealing with the same topics wouldn't be a problem. Obviously there's also the idea that I would really like to push the idea of cinema in that kind of world. There is so little being done, but it also is funnier for me to do it there. I thought I would try to push cinema somehow, up to a point, but it doesn't mean it's my only dimension.

AK: I appreciate your use of humor and light approach to profound, sometimes dark, subject matter.

JPB: Yeah. It's also kind of a philosophy about life: things are serious, but not serious at the same time. We take ourselves too seriously. And those are also some of the dimensions I like about African culture, where you have a light perspective, and keep the big picture in mind. You have power over yourself and events by how you look at it, and being able to laugh at it. You have power- it's kind of like the power of the weaker.

AK: Jumping topics. You've mentioned several times how difficult it is to answer the question of where you live. I'm wondering to what extent, if any, this factor inflects your work.

JPB: First, I don't think that just because I don't have an address means that I don't have roots. I think I do have roots. Each culture that I've spent time in, whether it's French, Cameroonian, or even American culture, I feel that I was able to go deep, beyond the surface, and took a little bit of each one with me, I carry them with me. And I think that's where the identity is, really. It's not in the address. I think that when people feel as if they can't locate you they feel very uncomfortable; they want to put it in a box. In fact, I do have one fixed address: in 1995, bekolo@yahoo.com became my address, and it made me feel very good.

There is a kind of oppression of what I call the indigenous people. I always feel like people who stay in one place feel like they have more power, I don't know why. There is almost an oppression of those who stay in one place - the indigenous - over the other ones, those who leave, travel, move around. That's one of the things all over the world that I think is crippling mankind: it's not about your contribution to humanity, it's about being the one who's here since the beginning, and you feel like you have more rights than someone who just came, even if you have nothing to offer. People who travel first take a chance. There is something they decide to change about something, and they always learn something. They always have something to offer, but, most of the time, the indigenous are really hard on them. I call "indigenous" those who stay back home where they [the traveler or emigrant] left, or those who belong to the new place. My conviction is that mankind can really evolve if people move around; we can have the opportunity to contribute more, but unfortunately they are very limited, at least in the world we live in. When we did this project on the diaspora...[trails off $]^{2}$

AK: I ask this question because if you look at other contemporary filmmakers who have a franco-African identity, such as Alain Gomis (franco-sénégalais), Newton Aduaka, Abderrahmane Sissako, Mahamat-Saleh Haroun, Balufu Bakupa-Kanyinda...in some ways you are part of this group, but you are so different in so many interesting ways. With their films, it really comes through that they're straddling cultures, and pursuing a quête identitaire...Do you

\footnotetext{
${ }^{2}$ The project to which he is referring was an exhibition titled Diaspora, organized by Claire Denis in 2007 at the Musée du Quai Branly in Paris. Bekolo's film installation is Une Africaine dans l'espace.
} 
see yourself in line with other contemporary filmmakers, perhaps ones that I've named, or ones that I haven't named?

JPB: One of the things that I've always tried... when I made Quartier Mozart, I didn't want people to even know that I'd been in France. I don't know why. Because I felt that it's not about engaging with the West, with France, it was just creating a culture of our own. I grew up without films, or maybe 2 or 3 Cameroonian films, so I felt like maybe I should give young Cameroonians a film. Going to Europe, even if I embraced a lot of culture, I really didn't agree with the whole identity topic. Because I felt like it was pushed on us. If you take all the Europeans coming to America, were they really on an identity quest? And when you take Africans, like me going when I was about 20, I really don't think everybody was on an identity quest. Some people, sure. But I don't think it's the only dimension of a person who travels. I think it became almost like a theme a lot of the French commissioning editors, whoever they were, were really pushing on Africans. Obviously a human being is very complex. But I don't think everyone who travels ends up having an identity problem. And you have so many journeys people have been making in mankind, all over the world. But I don't think that what you remember from people who travel is just that they're lost.

Maybe the difference between me and many others is that I started [filmmaking] when I was very young. Most of those that you mentioned, except Alain Gomis, are older than me, but started after me. My feeling is that we don't have the same definition of cinema, that's what I think. Obviously I'm not saying that I have a better definition. I really think that's where the difference is, and it's a very fundamental definition. It doesn't matter if we're all Africans, but if we don't think cinema is the same thing, there's no way we could look alike, our work could look alike. People have different backgrounds also. I think I'm one of the only technicians; I started out as an editor. None of these people are film technicians. Maybe being an editor gives me more confidence when shooting or whatnot. What's worst, very few have a literary background; some of them are almost illiterate - I'm not trying to be mean! Whatever your initial training is really affects you; that's where your identity as a filmmaker really comes out. Someone like Balufu spent a lot of time in political and intellectual circles at universities debating Africanist stuff, so you can feel that background sticks to him. Haroun started more as a journalist, I think. Abderrahmane I'm not very sure. So anyway, what I'm saying is rather than looking at ethnicity, or geo-politics, is more what they learned when they started making movieswhere you're actually coming from technically, or intellectually. I think that's where you'll see exactly who's who. The fact that I was an editor, the fact that I studied semiotics is very important, also because it gave me a lot of confidence, at least to engage intellectually but with a discipline like semiotics, which is the language of science... The early stage was useful to create whatever I've become.

AK: Were you drawn to semiotics because of your scientific background, especially in physics?

JPB: It's the way my brain was formatted by science. It's funny- when I was writing a script, I kept saying, "a script is not math!" because I was very structural. In fact, I like structuralism a lot, I've read a lot of structuralism, and even when I write a script I use structuralism a lot, meaning what is the shape, the skeleton you give to a film. Obviously Aristotle's beginning, middle, and end, but there are many other ways you can structure a story; I'm very structuralist in that sense, maybe because I'm not literary, but because I'm somebody who likes to create 
points...tac, tac, tac.. At the same time, I was too structural that I could kill the feel, the flow, the emotion, so I always try to make sure that I don't structure too much. I also had to keep human life taking over. I had to kind of de-program myself from the structuralist approach, fight against my urges.

One of the books I like a lot is L'analyse structurale du récit [Roland Barthes, 1981]. And you have many, many, many models for structuring stories. Tzvetan Todorov, the Russians were actually more important in structuralism. They almost had kind of an equation for tales, almost a mathematic equation for tales. The history of structuralism is very interesting. One guy in that same book was actually breaking down the pope's death, I don't remember which one, but how the newspapers would tell that story. Umberto Eco, a semiotician, has worked a lot on James Bond and on how the story's structured. There are many, many ways...that's why I always make fun of...Robert Mackey...Aristotle says a good story has a beginning, middle, and an end, which is a big, open structure, but there are many, many other possibilities and structures. It doesn't lead to what you call classical realist narratives. I actually think structuralism is a field that should be taught more in film.

AK: You have taught at American universities. Have you ever taught that?

JPB: L'analyse structurale du récit...one of my professors, Jules Gritti, was actually in that book. So I think just to show how wide the possibility of story structures are, which today are being narrowed by these gurus.

I think a film is supposed to be, for the person who watches it, a journey. You have to take them on a journey that they don't have a clue about, they don't know where you're taking them. Now, the problem is that they should feel comfortable going on a journey that they don't know anything about. But unfortunately the current, predictable structure of scripts and narrative make them unwilling to go on an unknown journey. And I think it's affecting the brain. If you imagine how in real life if they get exposed to something they can't predict, obviously the brain is not used to it. And I always say that Africans have so many problems to solve (laughs). But if you condition them - their brain - into one dimension, they will be more crippled than the western world, where there are more means to solve their problems. So many films that are completely formulaic is not just crippling people, it's crippling the whole continent - if we consider cinema as big space, which is not everywhere the case, but with Nollywood and all this stuff, it's getting it there.

About Nollywood, I always say, tell me that Nollywood film that really touched you. You always need that one piece of artwork, that one book, that one film, etc. that touched you, but nobody's talking about that one film that really struck you with regards to Nollywood. Which means that Nollywood is like a picture that's there. It's a useful picture, because in the space of television, Africans didn't have an image to identify themselves with. Now with Nollywood they have an image out there, but it doesn't really play the role that film should be playing. It's playing another role, maybe just making people feel that they're represented in this medium, or making them feel they exist because of identification. Like how kids like movies because there's another kid in them. Africans like movies because there are other Africans on the screen. Identification creates interest. Not like a mirror. It's no longer one person the whole world identifies with, now the culture is changing.

I like this whole idea of making movies from a place, rather than making movies for an audience. It's now a little bit stronger than before, because this whole concept of making movies 
for an audience - which, I feel, from a filmmaker's perspective is not manipulative, but a little bit opportunistic - why don't you just make movies from where you are; this is what I see from here. I think it's more relevant today than this industrial film production where you target [specific audiences].

AK: Could you talk a little bit about how you put images and music together? Do you have music in mind when you're filming?

JPB: I think filming is musical; rhythm is all over the place. Walking is a rhythm, camera following is a rhythm, cutting all this together is a rhythm, adding music is a rhythm. So the whole game is about playing with all these different rhythms - it's not about making them the same. It's almost like a composer, adding some bass here, drums there... so I just think you have to play with all these rhythms. It's just like another layer in a way, but that has to be talking to the other layers too, which are movement, camera movement, characters talking, and all the stuff. You have to feel it, feel what's going on, and respond to it - that, for me, is how music comes in.

AK: What are your tastes in music?

JPB: I'll say what Mani Dibango used to say, that music should always go from up to down, meaning down to the feet so that the feet start moving. Ça chatouille... 


\section{Filmography}

Abouna, directed by Mahamat-Saleh Haroun (Los Angeles, CA: Duo Films, 2002), DVD.

Aristotle's Plot, directed by Jean-Pierre Bekolo (1996; Paris: JBA Production, 2004), DVD.

Badou Boy, directed by Djibril Diop Mambéty (1970; Rome: Raro Video, 2009), DVD.

Borom Sarret, directed by Ousmane Sembène (1963; New York, NY: New Yorker Films, 2000), VHS.

Bye Bye Africa, directed by Mahamat-Saleh Haroun (San Francisco, CA: California Newsreel, 1999), VHS.

Juju Factory, directed by Balufu Bakupa-Kanyinda (Paris, France: Akangbe Productions, 2006), DVD.

Le Clandestin, directed by José Zéka Laplaine. Cinémas d'Afrique (France: Centre National de Documentation Pédagogique, 2001), DVD.

Le Damier - Papa National Oyé!, directed by Balufu Bakupa-Kanyinda (1996; New York, NY: ArtMattan Productions, 2000), DVD.

Le Franc, directed by Djibril Diop Mambéty (1994; Paris: La Médiathèque des Trois Mondes, 2002), DVD.

Les Saignantes, directed by Jean-Pierre Bekolo (Yaoundé, Cameroon: Cinénomada: 2005), DVD.

Lieux Saints, directed by Jean-Marie Teno (Issy-les-Moulineaux, France: Les Films du Raphia, 2009), DVD.

The Floorwalker, directed by Charlie Chaplin. The Chaplin Mutual Comedies (1916;

Chatsworth, CA: Image Entertainment, 2006), DVD.

The Gold Rush, directed by Charlie Chaplin (Burbank, CA: Warner Home Video, 2003), DVD.

The Great Dictator, directed by Charlie Chaplin (1940; Chatsworth, CA: Image Entertainment, 2000), DVD.

The Immigrant, directed by Charlie Chaplin. The Chaplin Mutual Comedies (1917; Chatsworth, CA: Image Entertainment, 2006), DVD.

The Kid, directed by Charlie Chaplin (1921; Burbank, CA: MK2 Editions, Warner Home Video, 2003), DVD. 
The Pawnshop, directed by Charlie Chaplin. The Chaplin Mutual Comedies (1916; Chatsworth, CA: Image Entertainment, 2006), DVD.

Xala, directed by Ousmane Sembène (1975; New York, NY: New Yorker Films, 2005), DVD. 


\section{Bibliography}

Adesokan, Akin. Postcolonial Artists and Global Aesthetics. Bloomington and Indianapolis: Indiana University Press, 2011.

— "The Challenges of Aesthetic Populism: An Interview with Jean-Pierre Bekolo." Postcolonial Text 4 (18 May 2008): 1-11.

Akudinobi, Jude G. "Tradition/Modernity and the Discourse of African Cinema." Iris 18 (1995): 25-38.

"An African-Owned Cinema in Bathurst, Gambia." Colonial Cinema 6.4 (December 1948): 7678.

Appiah, Kwame Anthony. In My Father's House: Africa in the Philosophy of Culture. Oxford: Oxford University Press, 1992.

Armes, Roy. African Filmmaking North and South of the Sahara. Bloomington and Indianapolis: Indiana University Press, 2006.

- Dictionary of African Filmmakers. Bloomington and Indianapolis: Indiana University Press, 2008.

Asplund, Uno. Chaplin's Films: A Filmography. Translated by Paul Britten Austin. Newton Abbot: David \& Charles, 1973.

Austen, Ralph A. and Mahir Şaul, eds. Viewing African Cinema in the Twenty-First Century: Art Films and the Nollywood Video Revolution. Athens, OH: Ohio University Press, 2010.

Bakupa-Kanyinda, Balufu. "Djibril Diop Mambety: tribut cinématographique à Colobane." In Afriques 50: singularités d'un cinéma pluriel, edited by Catherine Ruelle, 277-280. Paris: L'Harmattan, 2005.

—. "Film in Africa, Africa in Film: Challenging Stereotypes." UN Chronicle 40, no. 1 (March-May 2003): 27.

Barber, Karin. "Popular Arts in Africa." African Studies Review 30, no. 3 (Sept. 1978): 1-78.

Barlet, Olivier. African Cinemas: Decolonizing the Gaze. Translated by Chris Turner. London: Zed Books, 2000.

. "À Propos de Le Clandestin et Macadam Tribu. Entretien d'Olivier Barlet avec José Laplaine, Fespaco 97.” Africultures (August 2002). http://www.africultures.com/php $/$ ?nav $=$ article $\&$ no $=2439$. 
—. Les Cinémas d'Afrique: le regard en question. Paris: L'Harmattan, 1996.

“Abouna, Éloge du Respect. Entretien d'Olivier Barlet avec Mahamat Saleh

Haroun, Cannes mai 2002." Africultures (May 2003). http://www.africultures.com/php /index.php?nav=article\&no=2358.

"Le Développement est une diplomatie qui n'a rien à vois avec la qualité. Entretien d'Olivier Barlet avec Balafu Bakupa-Kanyinda à propos de Juju Factory." Africultures (August 2006). http://www.africultures.com/php/?nav=article\&no=4558.

__ . "Entretien d'Olivier Barlet avec Jean-Pierre Bekolo à propos de Les Saignantes: Être à la fois africain et contemporain." Africultures (July 2005). http://www.africultures.com $/ \mathrm{php} /$ ?nav $=$ article $\&$ no $=3944$.

—. Les cinémas d'Afrique des années 2000: perspectives critiques. Paris: L'Harmattan, 2012.

Bekolo, Jean-Pierre. “Aristotle's Plot.” African Images: Recent Studies and Text in Cinema, edited by Kenneth Harrow and Emmanuel Yewah, 19-29. Trenton: Africa World Press, 2000.

- Interview by Anna V. Keefe. February 14, 2014. The University of Virginia, Charlottesville, VA.

Beus, Yifen. "Authorship and Criticism in Self-Reflexive African Cinema." Journal of African Cultural Studies 23, no. 2 (December 2011): 133-152.

Bordwell, David and Kristin Thompson. Film Art: An Introduction. Boston: McGraw-Hill, 2004.

Boughedir, Férid. African Cinema from A to Z. Brussels: OCIC, 1992.

Bruzzi, Stella. New Documentary: A Critical Introduction. London: Routledge, 2000.

Burton, Julianne. "Film Artisans and Film Industries in Latin America, 1956-1980: Theoretical and Critical Implications of Variations in Modes of Filmic Production and Consumption." In New Latin American Cinema, Vol. 1, edited by Michael T. Martin, 157-184. Detroit: Wayne State University Press, 1997.

Chambers, Colin. Here We Stand: Politics, Performers and Performance. London: Nick Hern Books, 2006.

Conley, Tom. Film Hieroglyphs: Ruptures in Classical Cinema. Minneapolis: University of Minnesota Press, 2007.

Dalle Vacche, Angela. "A Film is Trying to Build a Sort of Eternity: An Interview with 
Mahamet-Saleh Haroun.” Senses of Cinema 47 (May 2008). http://sensesofcinema.com /2008/feature-articles/mahamet-saleh-haroun/.

de Groof, Matthias. "How Text Reflects Context: Representation of African Film Audiences in Aristotle's Plot." Journal of African Cinemas 5, no. 2 (2013): 181-202.

_ . "Intriguing African Storytelling: On Aristotle's Plot by Jean-Pierre Bekolo." In Storytelling in World Cinemas, Vol. 1 - Forms, edited by Lina Khatib, 115-131. New York: Columbia University Press, 2012.

Deleuze, Gilles. Cinema 1: The Movement-Image. Translated by Hugh Tomlinson and Barbara Habberjam. Minneapolis: University of Minnesota Press, 2009.

Diabate, Naminata. “Ambivalence towards the African Woman's Body: Jean Pierre Bekolo's Les Saignantes (The Bloodletters) and the Mevoungou." In Women, Gender, and Sexualities in Africa, edited by Toyin Falola and Nana Akua Amponsah, 21-38. Durham: Carolina Academic Press, 2012.

Diawara, Manthia. African Cinema: Politics and Culture. Bloomington: Indiana University Press, 1992.

African Film: New Forms of Aesthetics and Politics. Munich: Prestel, 2010.

Dima, Vlad. "Ousmane Sembene's La Noire de...: Melancholia in Photo, Text, and Film." Journal of African Cultural Studies 26, vol. 1 (2014): 56-68.

Dovey, Lindiwe. Curating Africa in the Age of Film Festivals. New York: Palgrave Macmillan, 2015.

Ekotto, Frieda and Kenneth Harrow, eds. Rethinking African Cultural Production. Bloomington and Indianapolis: Indiana University Press, 2015.

Fanon, Frantz. Les damnés de la terre. Paris: Petite Collection Maspero, 1976.

Felton, Wes. "Caught in the Undertow: African Francophone Cinema in the French New Wave." Senses of Cinema 57 (December 2010). http://sensesofcinema.com/2010/feature-articles /caught-in-the-undertow-african-francophone-cinema-in-the-french-new-wave/.

Gabara, Rachel. “"A Poetics of Refusals': Neorealism from Italy to Africa.” Quarterly Review of Film and Video 23 (2006): 201-215.

—_. "Abderrahmane Sissako: Second and Third Cinema in the First Person." In Global Art Cinema: New Theories and Histories, edited by Rosalind Galt and Karl Schoonover, 320333. Oxford: Oxford University Press, 2010.

Gabriel, Teshome. Third Cinema in the Third World: The Aesthetics of Liberation. Ann Arbor: 
UMI Research Press, 1982.

- "Towards a Critical Theory of Third World Films." In Cinemas of the Black Diaspora: Diversity, Dependence, and Oppositionality, edited by Michael T. Martin, 70-90. Detroit: Wayne State University Press, 1995.

Gadjigo, Samba. Ousmane Sembène: The Making of a Militant Artist. Translated by Moustapha Diop. Bloomington and Indianapolis: Indiana University Press, 2010.

Gaoh, Zeinabou. “Entretien avec Mme Fanta Régina Nacro, Réalisatrice Burkinabé,” Le Sahel.org, (January 30, 2013). http://www.lesahel.org/index.php/component/k2/item /2298-entretien-avec-mme-fanta-regina-nacro-realisatrice-burkinabe.

Garritano, Carmela. African Video Movies and Global Desires: A Ghanaian History. Athens, OH: Ohio University Press, 2013.

Genova, James E. Cinema and Development in West Africa. Bloomington and Indianapolis: Indiana University Press, 2014.

Gugler, Josef. African Film: Re-Imagining a Continent. Bloomington and Indianapolis: Indiana University Press, 2003.

—. "African Writing Projected onto the Screen: Sambizanga, Xala, and Kongi's Harvest." African Studies Review 42, vol. 1 (1999): 79-104.

Gunning, Tom. “'Now You See It, Now You Don't': The Temporality of the Cinema of Attractions." In Silent Film, edited by Richard Abel, 71-84. New Brunswick, NJ: Rutgers University Press, 1996.

Gutberlet, Marie-Hélène. "Towards an Aesthetic of the Migrant Self-The Film Le Clandestin by José Zeka Laplaine.” In Transcultural Modernities: Narrating Africa in Europe. Matatu - Journal for African Culture and Society 36, edited by Elisabeth Bekers, Sissy Helff, and Daniela Merolla, 287-295. Amsterdam and New York: Editions Rodopi, 2009.

Haffner, Pierre. "Sembène Ousmane in Kinshasa." In Ousmane Sembène: Interviews, edited by Annett Busch and Max Annas, 82-98. Jackson: University Press of Mississippi, 2008.

Hale, Thomas. Griots and Griottes: Masters of Words and Music. Bloomington and Indianapolis: Indiana University Press, 1998.

Hansen, Miriam. Babel and Babylon: Spectatorship in American Silent Film. Cambridge, MA: Harvard University Press, 1991.

Harrow, Kenneth. Postcolonial African Cinema: From Political Engagement to Postmodernism. Bloomington and Indianapolis: Indiana University Press, 2007. 
—. Trash: African Cinema From Below. Bloomington and Indianapolis: Indiana University Press, 2013.

—. "What's an Old Man Like You Doing with a Saignante Like Me?" In Facts, Fiction and African Creative Imaginations, edited by Toyin Falola and Fallou Ngom, 190-206. New York: Routledge, 2010.

Haynes, Jonathan. "African Filmmaking and the Postcolonial Predicament: Quartier Mozart and Aristotle's Plot." In Cinema and Social Discourse in Cameroon, edited by Alexie Tcheuyap, 114-132. Bayreuth: Thielmann and Eckhard Breitinger, 2005.

Hedrén, Katarina. Africa is a Country (blog). http://africasacountry.com/5-questions-for-afilmmaker-dani-kouyate/.

Hoefert de Turégano, Teresa. African Cinema and Europe: Close-Up on Burkina Faso. Florence: European Press Academic Publishing, 2004.

_. "Sub-Saharan African Cinemas: The French Connection." Modern \& Contemporary France 13, no. 1 (February 2005): 71-83.

Izzo, Justin. “Jean-Marie Teno’s Documentary Modernity: From Millennial Anxiety to Cinematic Kinship.” African Studies Review 58, no. 1 (April 2015): 39-53.

Jaji, Tsitsi Ella. Africa in Stereo: Modernism, Music, and Pan-African Solidarity. New York: Oxford University Press, 2014.

“Jean Rouch: Biographie longue." Comité du Film Ethnographique. Accessed September 2, 2014. http://www.comite-film-ethno.net/jean-rouch/biographie-longue.html.

Jeffries, Stuart. “Out of Africa.” The Guardian (November 14, 2002). http://www.theguardian. com/culture/2002/nov/15/artsfeatures3.

Joslin, Isaac V. "Baroque practices in postcolonial African literature and theory: from Achille Mbembe's On the Postcolony." International Journal of Francophone Studies 12, no. 4 (2009): 639-654.

Kline, T. Jefferson. Screening the Text: Intertextuality in New Wave French Cinema. Baltimore: Johns Hopkins University Press, 1992.

La Guilde. "Pour un nouveau cinéma africain." In Afriques 50: singularités d'un cinéma pluriel, edited by Catherine Ruelle, 269-271. Paris: L'Harmattan, 2005.

Larke-Walsh, George S. "Point Your Finger and Say, 'That's the Bad Guy': Performativity in Donal MacIntyre's A Very British Gangster (2007)," Journal of Film and Video 64, no. 3 (Fall 2012): 53-66. 
Levine, Alison J. Murray. Framing the Nation: Documentary Film in Interwar France. New York: Continuum, 2010.

_. "'Provoking Situations': Abderrahmane Sissako's Documentary Fiction." Journal of African Cinemas 3, no. 1 (2011): 93-107.

- "Words on Trial: Oral Performance in Abderrahmane Sissako's Bamako." Studies in French Cinema 12, no. 2 (2012): 151-167.

Maasdorp, Liani. "Looking In, Looking Out: The Self-Reflexive Mode of Representation in a Selection of Contemporary South African Documentary Films." South African Theatre Journal 25, no. 3 (November 2011): 208-226.

Marks, Laura. The Skin of the Film: Intercultural Film, Embodiment, and the Senses. Durham: Duke University Press, 2000.

Martin, Michael T. and Marissa Moorman. "The Civilising Mission of Globalisation. Technology, African Cinematic Practice and Overcoming Neocolonialism: A Conversation with Film-maker Jean-Marie Teno.” Third Text 29, no. 1-2 (2015): 61-74.

Mbembe, Achille. On the Postcolony. Berkeley, Los Angeles and London: University of California Press, 2001.

Metz, Christian. "The Impersonal Enunciation, or the Site of the Film (In the Margin of Recent Works on Enunciation in Cinema)." Translated by Béatrice Durand-Sendrail and Kristen Brookes. New Literary History 22, no. 3 (Summer 1991): 747-772.

Mulvey, Laura. "Visual Pleasure and Narrative Cinema," Screen 16, no. 3 (Autumn 1975): 6-18.

Murphy, David. "Africans Filming Africa: Questioning Theories of an Authentic African Cinema." Journal of African Cultural Studies 13, vol. 2 (2000): 239-249.

Murphy, David, and Patrick Williams. Postcolonial African Cinema: Ten Directors. Manchester and New York: Manchester University Press, 2007.

Murphy, Libby. "Charlot Français: Charlie Chaplin, the First World War, and the Construction of a National Hero." Contemporary French and Francophone Studies 14, no. 4 (September 2010): 421-429.

Naficy, Hamid. An Accented Cinema: Exilic and Diasporic Filmmaking. Princeton: Princeton University Press, 2001.

Nell, Louis. "The Mobile Cinema in Northern Rhodesia." Colonial Cinema 6, vol. 2 (June 1948): 43-46.

Nganang, Alain Patrice. “Deconstructing Authority in Cinema: Jean-Marie Teno.” In Cinema 
and Social Discourse in Cameroon, edited by Alexie Tcheuyap, 139-158. Bayreuth: Thielmann \& Breitinger, 2005.

Ngangura, Mweze. “African Cinema: Militancy or Entertainment?” In African Experiences of Cinema, edited by Imruh Bakar and Mbye Cham, 60-64. London: BFI, 1996.

Niang, Sada. Djibril Diop Mambéty: Un cinéaste à contre-courant. Paris: L’Harmattan, 2002.

- Nationalist African Cinema: Legacy and Transformations. Lanham: Lexington Books, 2014.

Nichols, Bill. Introduction to Documentary, 2nd ed. Bloomington: Indiana University Press, 2001.

Noble, George. "Cameraman on the Gold Coast." Colonial Cinema 10, no. 2 (June 1952): 36-39.

Notcutt, L.A., and G.C. Latham. The African and the Cinema: An Account of the Work of the Bantu Educational Cinema Experiment During the Period March 1935 to May 1937. London: The Edinburgh House Press, 1937.

Obama, Jean-Pierre Bekolo. Africa for the Future: Sortir un nouveau monde du cinéma. Achères, France: Éditions Dagan, 2009.

Omelsky, Matthew. “Jean-Pierre Bekolo’s African Cyborgian Thought.” Journal of Contemporary African Art 31 (Fall 2012): 6-21.

Oscherwitz, Dayna. "Bye Bye Hollywood: African Cinema and Its Double in Mahamet-Saleh Haroun's Bye Bye Africa." In Hollywood's Africa After 1994, edited by MaryEllen Higgins, 240-259. Athens, OH: Ohio University Press, 2012.

—. "Of Coyboys and Elephants: Africa, Globalization and the Nouveau Western in Djibril Diop Mambety's Hyenas.” Research in African Literatures 39, no. 1 (Spring 2008): 223238.

Ouédraogo, Jean. "Extraits d'un entretien avec Dani Kouyaté. Entretien réalisé par Jean Ouédraogo le 6 mars 2003 à Ouagadougou." Site officiel de Dani Kouyaté (May 18, 2011). http://www.dani-kouyate.com/fr/presse/oeuvre030306.php.

“Ousmane Sembène: l'œil doit entendre," L'OBS. May 16, 2005. http://tempsreel.nouvelobs.com /culture /20050516.OBS6805/ousmane-sembene-l-oelig-il-doit-entendre.html.

Petty, Sheila. "Sacred Places and Arlit: Deuxième Paris: Reterritorialization in African Documentary Films." Nka: Journal of Contemporary African Art 32 (Spring 2013): 7079.

Pfaff, Françoise. "Five West African Filmmakers on Their Films.” A Journal of Opinion 20, no. 
2 (1992): 31-37.

—. "Paulin Soumanou Vieyra: pionnier de la critique et de la théorie du cinéma africain," Présence Africaine 170, no. 2 (2004): 27-34.

—. "Three Faces of Africa: The Women in Xala." Jump Cut: A Review of Contemporary Media 27 (1982): 27-31.

Polan, Dana B. "Brecht and the Politics of Self-Reflexive Cinema," Jump Cut: A Review of Contemporary Media 17 (1978). http://www.ejumpcut.org/archive/onlinessays/JC17 folder/BrechtPolan.html.

Prabhu, Anjali. Contemporary Cinema of Africa and the Diaspora. West Sussex, UK: Wiley Blackwell, 2014.

Rothman, William. The "I" of the Camera: Essays in Film Criticism, History, and Aesthetics. 2nd edition. Cambridge: Cambridge University Press, 2004.

Rugg, Linda. Self-Projection: The Director's Image in Art Cinema. Minneapolis: The University of Minnesota Press, 2014.

Sanches, Manuela Ribeiro. “African Screens (Re)Viewed from Lisbon.” Nka: Journal of Contemporary African Art 27 (Fall 2010): 54-61.

Sanogo, Aboubakar. "Certain Tendencies in Contemporary Auteurist Film Practice in Africa." Cinema Journal 54, no. 2 (Winter 2015): 140-149.

Sayad, Cecilia. Performing Authorship: Self-Inscription and Corporeality in the Cinema. New York: I.B. Tauris, 2013.

Sembène, Ousmane. "Mes dates clés, par Ousmane Sembène," Libération (March 9, 2005). Accessed July 13, 2014. http://next.liberation.fr/cinema/2005/03/09/mes-dates-cles-parousmane-sembene_512235.

Sene, Fatou K. "Senegal: Balufu Bakupa-Kanyinda, cinéaste congolais: 'Tous mes films parlent de la grandeur de 1'Afrique." AllAfrica.com (January 24, 2011). http://fr.allafrica.com /stories/201101241983.html.

Shohat, Ella and Robert Stam. Unthinking Eurocentrism: Multiculturalism and the Media. New York: Routledge, 1994.

Snell, Heather. "Towards a 'Giving and Receiving': Teaching Djibril Diop Mambéty's Touki Bouki." Journal of African Cultural Studies 26, no. 2 (2014): 127-139.

Spurr, Norman. "The Mobile Cinema Van is a New Weapon of Mass Education." Colonial Cinema 7, no. 2 (March 1949): 9-10. 
—. "Coating the Pill," Colonial Cinema 9, no. 1 (March 1951): 21-22.

Ssali, Ndugu Mike. “Apartheid and Cinema." In African Experiences of Cinema, edited by Imruh Bakari and Mbye B. Cham, 83-101. London: British Film Institute, 1996.

Stam, Robert. Reflexivity in Film and Literature: From Don Quixote to Jean-Luc Godard. New York: Columbia University Press, 1992.

Stoneman, Rod. "South/South Axis: For a Cinema Built by, with and for Africans." In African Experiences of Cinema, edited by Imruh Bakari and Mbye B. Cham, 175-180. London: British Film Institute, 1996.

Tcheuyap, Alexie. Postnationalist African Cinemas. Manchester: Manchester University Press, 2011.

Teno, Jean-Marie. "Writing On Walls: Documentary, The Future of African Cinema?" Africultures (March 2010). http://www.africultures.com/php/?nav=article\&no=10003.

Thackway, Melissa. Africa Shoots Back: Alternative Perspectives in Sub-Saharan Francophone African Film. Bloomington: Indiana University Press, 2003.

_ . "Exile and the 'Burden of Representation': Trends in Contemporary Sub-Saharan Francophone African Filmmaking." Black Camera 5, no. 2 (Spring 2014): 5-20.

“The Mobile Cinema Van in the Villages.” Colonial Cinema (March 1945): 11-12.

Toman, Cheryl. Contemporary Matriarchies in Cameroonian Francophone Literature: 'On est ensemble'. Birmingham, Alabama: Summa Publications, 2008.

Truffaut, François. "Une certaine tendance du cinéma français.” Cahiers du cinéma 31 (January 1954): 15-29.

Ukadike, Nwachukwu Frank. Black African Cinema. Berkeley and Los Angeles: University of California Press, 1994.

- Questioning African Cinema: Conversations with Filmmakers. Minneapolis: University of Minnesota Press, 2002.

—. "The Other Voices of Documentary: Allah Tantou and Afrique, je te plumerai," In Focus on African Films, edited by Françoise Pfaff, 159-172. Bloomington: Indiana University Press, 2004.

Vaughan, J. Koyinde. "Africa South of the Sahara and the Cinema." Présence Africaine 14-15 (June-September 1957): 210-221. 
Vieyra, Paulin Soumanou. Le Cinéma Africain: Des Origines à 1973. Tome I. Paris: Présence Africaine, 1975.

Virilio, Paul. Guerre et Cinéma. Paris: Éditions de l’Étoile, Seuil, 1984.

Vlam, Peter. "Gaston Kaboré on African Film," The Power of Culture (September 2005). http://www.krachtvancultuur.nl/en/current/2005/september/kobore.html.

Williams, James S. "Male Beauty and the Erotics of Intimacy: The Talismanic Cinema of Mahamat-Saleh Haroun.” Film Quarterly 67, no. 4 (Summer 2014): 33-43.

Woll, Josephine. "The Russian Connection: Soviet Cinema and the Cinema of Francophone Africa." In Focus on African Films, edited by Françoise Pfaff, 223-240. Bloomington: Indiana University Press, 2004.

Wynchank, Anny. “Djibril Diop-Mambety, fondateur d'un cinéma nouveau." CinémAction 106 (2003): 93-98.

—. Djibril Diop Mambety ou le voyage du voyant. Ivry-sur-Seine: Éditions A3, 2003.

Yervasi, Carina. “Ouaga Saga, Magical Realism, and Postcolonial Politics.” Research in African Literatures 39, no. 4 (Winter 2008): 40-57. 